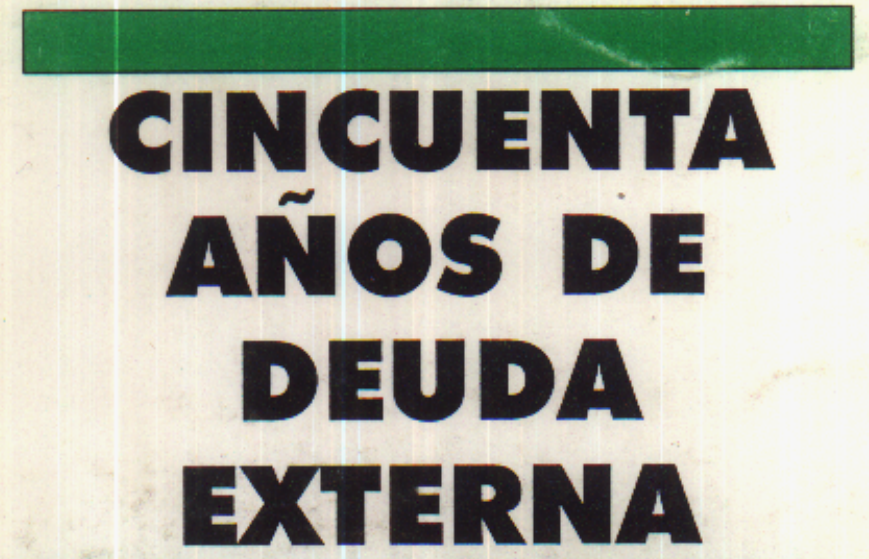

\title{
ALICIA GIRÓN
}
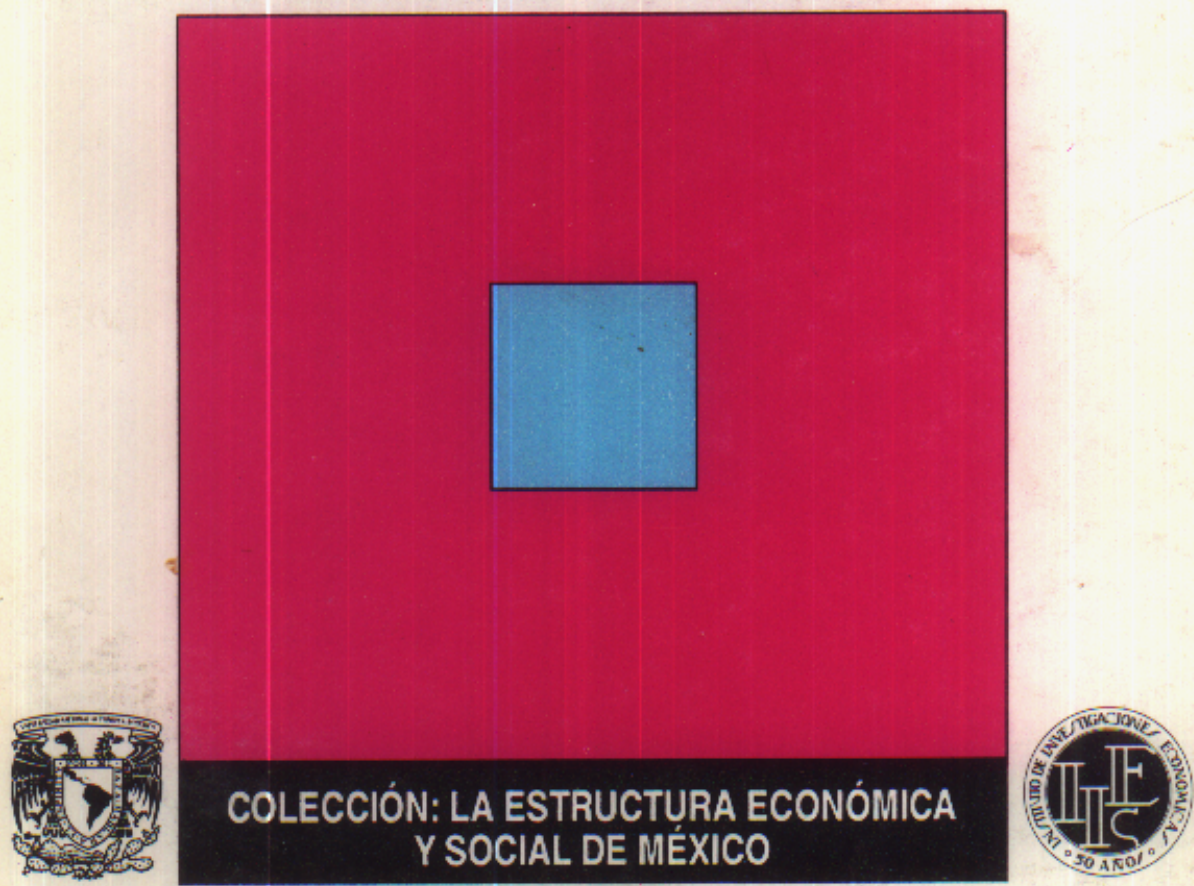

INSTITUTO DE INVESTIGACIONES ECONÓMICAS 


\title{
CINCUENTA ANTOS DE DEUDA EXTERNA
}

\author{
Alicia Girón
}

WNSTITUTO DE DVVETIOACIONES BCONOMICAS UNIVERSIDAD NACIONAL AUTOONOMA DE MÉXICO 


\section{UNIVERSIDAD NACIONAL AUTONOMA DE MÉXICO}

Dr. José Sarukhán Kérmez

Rector

Dr. Salvador Malo Álvarez

Secretario General

Mtro. Julio Labastida Martín del Campo

Coordinador de Humanidades

INSTITUTO DE INVESTIGACIONES ECONOMICAS

Lic Benito Rey Romay

Director

Dr. José Luis Rangel Díaz

Secretario Académico

Mtra. Verónica Villarespe Reyes

Secretaria Técnica

María Dolores de la Peña

Jefa del Departamento de Ediciones

Edición al cuidado de Rafael López González

- Instituto de Investigaciones Económicas, UNAM

Primera edicion: 1991

Derechos reservados conforme a la ley

Impreso y hecho en México

Printed and made in Mexico

ISBN 968-36-1917-7 
Para María Teresa y Luis Felipe 

Simón Bolívar-Aborrezco a las deudas más que a los españoles. Por eso le advertí a Santander que lo bueno que hiciéramos por la nación no serviría de nada si aceptábamos la deuda, porque seguiriamos pagando réditos por los siglos de los siglos... Gabriel García Márquez. El General en su laberinto. 



\section{ÍNDICE}

\section{INTRODUCCIÓN}

CAPÍTULO 1. EQUIVALENTE GENERAL Y CRÉDITO INTERNACIONAL

Equivalente general

Notas sobre el crédito y la función del capital en el proceso de internacionalización

Banca, trasnacionalización del capital

y endeudamiento externo

\section{CAPÍTULO 2. POLÍTICA Y DEUDA EXTERNA}

Del "despegue económico" al "desarrollo estabilizador",

Del "desarrollo compartido" a la "alianza para la producción",

Antecedentes de la "crisis de liquidez"

CAPÍTULO 3. ENDEUDAMIENTO MULTILATERAL

Características de la deuda externa en los años cuarenta

y cincuenta

Periodo de pre-crisis mundial

Canalización del crédito oficial por sectores

1968-1976

Características del endeudamiento público externo 1977-1987

CAPÍTULO 4. TRASNACIONALIZACIÓN DE LA DEUDA EXTERNA

Proceso del endeudamiento externo

El mercado del eurodólar 
México en el mercado de eurocréditos

El petroleo mexicano, el mercado de eurocréditos

y la banca trasnacional

\section{CAPÍTULO 5. DEUDA Y PROYECTO NEOLIBERAL}

Política de ajuste y pago de la deuda externa 166

$\begin{array}{ll}\text { Crisis y proyecto neoliberal } & 168\end{array}$

Características de los acuerdos del FMI 173

$\mathrm{El}$ proceso de renegociaciones 183

Del Plan Baker a los bonos "cupón cero" 197

CAPÍTULO 6. EL PLAN BRADY EN MÉXICO

La estrategia del Plan Brady $\quad 210$

La nueva estrategia mexicana 215

El plan nacional de desarrollo 1989-1994 219

CAPÍTULO 7. FIN Y PRINCIPIO DE UN NUEVO DESARROLLO

El equivalente general y el desfinanciamiento del desarrollo

Deuda y desarrollo: una propuesta alternativa

Conclusión final

Bibliografía 


\section{Introducción}

La historia del endeudamiento externo de México ha pasado por diferentes etapas. México, al igual que otros países latinoamericanos, ha sido parte del desarrollo del capital internacional desde el siglo XIX y ha participado de sus mutaciones durante el desenvolvimiento del sistema capitalista a nivel mundial.

Nuestro país, a partir de la década de los años cuarenta, forma parte de la dinámica expansionista de los organismos financieros internacionales y de una política de endeudamiento externo cuya intención fue apoyar el crecimiento económico. Es preciso reconocer al endeudamiento como parte de una política seguida por los gobiernos latinoamericanos. Su objetivo era alcanzar crecientes niveles de desarrollo industrial y económico, con base en la sustitución de importaciones y de programas tendientes a alcanzar un desarrollo integrado y autónomo. Este proceso iniciado después de la segunda guerra mundial estuvo encabezado por la recién creada Comisión Económica para América Latina y el Caribe (CEPAL), dependiente de la Organización de las Naciones Unidas, con el propósito de industrializar la región. Sin embargo, este proceso estuvo acompañado por el fortalecimiento de Estados Unidos como acreedor y como inversionista a través de sus empresas y bancos trasnacionales y de los organismos financieros internacionales; de tal forma, el dólar pasó a ser la principal moneda de reserva mundial. Esto ocasionó una profundización inédita de las condiciones naturales del capitalismo en la periferia del mundo subdesarrollado y la integración de las economías nacionales más atrasadas a la economía internacional. 
Hoy, bajo la amenaza de una deuda enorme e impagable, se sigue postergando la satisfacción de necesidades sociales ya de por sí rezagadas por las exigencias del desarrollo económico impuestas desde la posguerra. Pese a ello, tanto en el discurso teórico como en el lenguaje político, se repiten las coincidencias entre los gobiernos de los países endeudados y los organismos financieros oficiales que definen los intereses de las naciones industriales desarrolladas. Acreedores y deudores encuentran punto de contacto en el diálogo cuando, en un abanico de rasgos financieros polémicos sobre las condiciones del mercado mundial, coinciden en la apertura y expansión de las exportaciones y el comercio internacional como única fórmula para recaudar las divisas necesarias y solventar el pago de los intereses. No obstante esta fórmula - en cuyos límites se encuentra la imaginación de otras proposiciones sobre el endeudamiento externo- es estéril ante la realidad. Esta evidencia no parece suficiente motivo para descartarla. La situación real es que el endeudamiento, en tanto relación social de explotación, ha convertido al Tercer Mundo en tributario neto de capitales y de materias primas, centralizado por el capital financiero y por las grandes corporaciones trasnacionales. Pero estos hechos carecen de explicación en el idioma de los organismos financieros, que no ofrecen alternativas superadoras de la crisis. Sólo las categorías de la economía política ayudarán a los países deudores a entender el proceso de endeudamiento y la vorágine suscitada por el pago de sus obligaciones. Por tanto, es importante plantear en el discurso teórico y de la lucha ideológica el por qué de la adscripción universal a un mismo idioma y romper con dicho condicionamiento, desarrollando un discurso propio basado en las categorías de análisis del dinero como equivalente general, como agente de cambio, con referencia a la tasa de ganancia en tanto relación social.

En el capítulo primero de nuestro trabajo se hace un acercamiento teórico al problema del endeudamiento, retomando el estudio del crédito en el proceso de financiación de la acumulación capitalista. El estudio de categorías como el 
“equivalente general", la concentración, la centralización y la acumulación de capital; en el marco de la economía política vislumbran la trasnacionalización del capital y el endeudamiento externo. Aceptar el equivalente general como el cúmulo de deudas que agobian a los países subdesarrollados, representa la apreciación de un mecanismo social con enlaces de dependencia entre deudores y acreedores.

En el siguiente capítulo se estudia la política de deuda externa cuyas facetas constituyen el lenguaje oficial ligado a la política económica y al discurso ideológico del proyecto del "nacionalismo revolucionario". La lógica de un crecimiento auspiciado por la centralización y concentración del capital financiero internacional, en el marco del sistema internacional a lo largo de los últimos 50 años, producen un financiamiento para el desarrollo caracterizado en tres etapas. La primera del "despegue económico" al "desarrollo estabilizador". La segunda del "desarrollo compartido" a la "Alianza para la producción" y la tercera etapa de la "crisis de liquidez" al "desfinanciamiento del país". Sin calificar sus éxitos y fracasos sólo los estudiamos al servicio de los comensales.

Se analiza posteriormente cómo el equivalente general irrumpe en la economía nacional y la engarza sutilmente al proceso de acumulación internacional a partir de la década de los cuarenta bajo la égida de los organismos financieros internacionales del recién creado Bretton Woods. El Estado, al consolidar su papel rector, canalizará hacia obras de infraestructura el financiamiento externo. En los sesenta la canalización hacia el proyecto industrial del país enfatizará el financiamiento del sector secundario. El cambio de un patrón a nivel internacional en los setenta pondera el sector primario dejando en manos de la banca privada trasnacional el $80 \%$ del financiamiento de sectores de punta. Los organismos financieros internacionales pierden influencia hasta mediados de los ochenta donde el Banco Mundial (BM) y Banco Interamericano de Desarrollo (BID) participarán del cambio estructural del país. 
Se profundiza el estudio del conglomerado trasnacional y su relación en el mercado internacional de capitales y en el financiamiento de la reproducción del capital en los setenta. La trasnacionalización de la deuda externa y la canalización de manera sorpresiva a los energéticos en un $90 \%$ admirarían a cualquier estudioso del problema por lo cual sin la inclusión política inhibirían el papel fundamental perseguido por Estados Unidos ante un vecino tan cercano como México y una posible confrontación en el Medio Oriente. La deuda externa más que una variable económica se vuelve un elemento primordial en la política internacional.

En el capítulo 5 se estudian las alternativas y soluciones presentadas a la crisis financiera internacional de 1982. Los Acuerdos firmados con el FMI y las sucesivas renegociaciones arman un discurso nacional haciendo suyas las implicaciones del proyecto neoliberal. El fracaso en los países prestatarios de dichas medidas para afrontar el pago del servicio de la deuda externa es un éxito para los acreedores en la medida en que el deudor se convierte en tributario de capitales. En reuniones de concertación, jamás de confrontación, se implican diferentes planes. Del Plan Baker a los bonos cupón cero el objetivo es disminuir la deuda vieja, aclamado por la mayoría y acompañado por la necesidad de la nueva deuda. Es así como lo plantea el Plan Brady, última alternativa presentada por los acreedores.

El Plan Brady cobra singular importancia por haber sido creado por Estados Unidos como estrategia política, económica y social para aplicarse al deudor modelo: México, en el marco de una integración de facto a Estados Unidos y bajo los lineamientos definidos de privatización, productividad, modernidad y estabilidad, establece una renegociación de su deuda externa con quitas al principal y reducción de intereses.

Por último se sintetiza el trabajo desarrollado en cada capítulo pero también se realizan en él toda una serie de proposiciones, alternativas y soluciones presentadas a lo largo de los últimos años, para culminar con la propuesta planteada por México sobre la disminución del pago de la deuda ex- 
terna bajo varios enfoques, en el marco de un compromiso social: el crecimiento.

Este libro es el producto de varios años de investigación. Como todo trabajo, se benefició con las valiosas contribuciones de varias personas, a quienes debo expresar mis más sinceros agradecimientos. Al maestro Arturo Bonilla, quien siendo director del Instituto de Investigaciones Económicas, sugirió el tema de la deuda externa de nuestro país y me motivó a estudiar a fondo el problema -empírica y teóricamente. $\mathrm{Al}$ doctor Edgar Ortiz, asesor de la investigación, quien dirigió y leyó acuciosamente los materiales presentados, e hizo valiosas sugerencias; con él siempre tuve un diálogo abierto y muy enriquecedor. Debo agradecer muy especialmente al maestro José Luis Ceceña y al licenciado Fausto Burgueño por el tiempo otorgado para desarrollar mi trabajo. Deseo hacer público mi reconocimiento por las atenciones que me brindó el licenciado José Luis Flores, exdirector de Organizaciones Financieras de la SHCP. No puedo dejar de agradecer el esfuerzo tedioso y repetitivo realizado por Blanca Estela Maya y Enrique Amaya en el trabajo mecanográfico. A Luis Daniel y Daniel Beltrán por su ayuda en la elaboración de los cuadros estadísticos. A todos ellos les debo el haberme podido acercar a un tema tan complejo cuya responsabilidad, como profesionista de la economía, requiere cada vez más una mayor profundización. Todo lo enunciado en este trabajo es de mi absoluta responsabilidad. 

1. EQUIVALENTE GENERAL Y CRÉDITO INTERNACIONAL

Explicar el endeudamiento externo desde una apreciación teórica, implica retomar el estudio del crédito en el proceso del financiamiento de la acumulación capitalista. Por otra parte, el estudio del proceso trasnacional de la banca privada internacional, en el ámbito de una crisis internacional del capitalismo, nos lleva al estudio de categorías como concentración y centralización del capital, relacionadas con tasa media de ganancia.

El estudio del equivalente general, al que hace referencia Marx,' en relación con el estudio del dinero como forma de intercambio entre productores y consumidores, es una categoría que representa una moneda de carácter universal mediante la cual se dan los créditos de acreedores a deudores. Dicha categoría internacional equivalente general, cuyos cambios de forma representan hoy en día un cúmulo de deudas por parte del Tercer Mundo, ha servido para comprar mercancías a los países desarrollados con objeto de atenuar el efecto de la crisis y de la recesión en los países industrializados. Este proceso ha sido a costa de una política de subvaluación del dólar o sobrevaluación del peso, dependiendo de los intereses del capital y de los grupos sociales relacionados con la realización y reproducción del capital, en su mayoría se verán plasmados en el transcurso del tiempo en la política pública ejercida por un Estado.

En este capítulo se abordan los siguientes puntos: el equivalente general; notas sobre el crédito; banca, trasnacionaliza-

${ }^{1}$ Marx, Karl. El Capital, tomo I, sección 3. Siglo XXı Editores, México, 1978. 
ción del capital y endeudamiento externo; y el sistema financiero internacional.

\section{Equivalente general}

La hipótesis central de este capítulo es mostrar al equivalente general como forma del endeudamiento externo. Éste representa la necesidad de intercambio de las mercancías entre acreedores y deudores a través de la moneda internacional del país hegemónico en el sistema capitalista mundial. Por tanto, ello implica la relación social en el intercambio entre dos formaciones sociales en el mercado del modo de producción capitalista. La dependencia del deudor frente al acreedor por la capacidad disponible de un mayor excedente y de mayores créditos se convierte en un proceso de interdependencia llegando a romper las barreras de las fronteras en aras de la producción del capital para formar un solo proceso de acumulación internacional.

Para explicar el endeudamiento externo como un equivalente general es necesario recordar que "...la riqueza de las sociedades en las que domina el modo de producción capitalista se presenta como un 'enorme cúmulo de mercancías', y la mercancía individual como la forma elemental de esa riqueza". 2

Por lo tanto, “...es precisamente la abstracción de sus valores de uso lo que caracteriza la relación de intercambio entre las mercancías". ${ }^{3}$ Continúa explicando. "En cuanto valores de uso, las mercancías son, ante todo, diferentes en cuanto a calidad; como valores de cambio sólo pueden diferir por su cantidad, y no contienen, por consiguiente, ni un solo átomo de valor de uso"'.4

El valor de cambio es el resultado del ser de las mercancías, pues son producto del trabajo. Intercambio que aparece intrínsecamente en el trueque. Los productos del trabajo

2 Op. cit., p. 43.

${ }^{3}$ Loc.cit., p. 46.

4 Ibid. 
a nivel internacional, donde impera el modo de producción capitalista, también se intercambian en el comercio mundial. Independientemente de las formas de trabajo imperantes en cada formación social, el trabajo humano es el creador del valor, de ahí que el promedio de la fuerza de trabajo es el trabajo socialmente necesario.

La mercancía que precisamente funge como equivalente general para llevar a cabo el intercambio es una mercancía muy peculiar porque su valor de uso le permite manifestar a otras mercancías lo contrario, es decir, su valor. Por ello, el oro es el representante del equivalente general en su forma oro. Es un sinónimo de riqueza desmedido. "De ahí lo enigmático de la forma de equivalente, que sólo hiere la vista burguesamente obtusa del economista cuando lo enfrenta, ya consumada, en el dinero". ${ }^{5} \mathrm{Al}$ profundizar en las formas del equivalente encontramos que "mediante su forma del valor [el equivalente general] se halla únicamente en relación social... con el mundo de las mercancías [ocasionando] que el valor de las mercancías sea indiferente con respecto a la forma particular del valor de uso en que se manifiesta". ${ }^{6}$ Por lo tanto, "se vuelve obvio que no es el intercambio el que regula la magnitud de valor de la mercancía, sino a la inversa, la magnitud de valor de la mercancía la que rige sus relaciones de intercambio". ? La magnitud de valor representa el promedio de la fuerza de trabajo de una sociedad. Por ello,

la magnitud de valor de una mercancía se mantendría constante, por consiguiente, si también fuera constante el tiempo de trabajo requerido para su producción. Pero éste varía con todo cambio en la fuerza productiva del trabajo. La fuerza productiva del trabajo está determinada por múltiples circunstancias, entre otras por el nivel medio de destreza del obrero, el estadio de desarrollo en que se hallan la ciencia y sus aplicaciones tecnológicas, la coordinación social del proceso de producción, la escala y la eficacia de los medios de producción, las condiciones naturales. ${ }^{8}$

${ }^{5}$ Op. cit., p. 71.

${ }^{6}$ Op. cit., p. 78. Subrayados de Marx.

7 Ibid.

${ }^{8}$ Op. cit., p. 49. 
Encontramos, por tanto, la forma relativa de valor y la forma general de valor.

La forma desplegada de valor ocurre de manera efectiva, por primera vez, cuando un producto del trabajo, por ejemplo las reses, ya no se intercambian excepcionalmente, sino de modo habitual, por otras mercancías diversas. ${ }^{9}$

Al grado de desarrollo de la forma relativa de valor corresponde el grado de desarrollo de la forma de equivalente. Pero conviene tener en cuenta que el desarrollo de la segunda no es más que expresión y resultado del desarrollo alcanzado por la primera. ${ }^{10}$

La tercera forma de equivalente general es cuando el equivalente deviene mercancía dineraria o funciona como dinero.

La clase específica de mercancías con cuya forma natural se fusiona socialmente la forma de equivalente, deviene mercancia dineraria o funciona como dinero. Llega a ser su función social especifica, y por lo tanto su monopolio social, desempeña dentro del mundo de las mercancias el papel de equivalente general. ${ }^{11}$

A medida que el oro funciona como equivalente general de mercancías singulares, y con el tiempo de todas las mercancías, se convierte en mercancía dineraria, y así "la forma IV se distingue de la III, o bien la forma general de valor llega a convertirse en la forma de dinero". ${ }^{12}$

Cuando Marx estudia el dinero, señala lo siguiente: “Con el objeto de șimplificar, en esta obra parto siempre del supuesto de que el oro es la mercancía dineraria." 13

El dinero, equivalente general, en su forma de oro o moneda internacional, sirve para el intercambio de mercancías no sólo de formaciones sociales distintas sino del sistema mundial de producción. En la medida en que el modo de producción capitalista es el predominante de todos los países, con mayor

\footnotetext{
${ }^{9}$ Ibid., p. 81.

${ }^{10}$ Ibid., p. 83.

11 Ibid., p. 85.

12 Ibid., p. 86.

${ }^{13}$ Ibid., p. 115.
} 
o menor grado de desarrollo de sus fuerzas productivas, el equivalente general sirve para llevar a cabo dicho intercambio.

Examinando la realidad internacional, donde existe una división internacional del trabajo, el endeudamiento externo, equivalente general, sirve para intercambiar mercancías de un país a otro. El equivalente general sirve para intercambiar medios de producción y fuerza de trabajo y adquiere significación de endeudamiento externo cuando el equivalente es otorgado por los acreedores y recibido por los deudores de un país para proseguir con el proceso de intercambio.

Dicho endeudamiento consiste en el otorgamiento de billetes u oro como formas del equivalente general para llevar a cabo políticas de financiamiento. En este momento no queremos ver el endeudamiento en otras expresiones, sino estudiarlo únicamente en su forma de equivalente y observamos que introduce al país deudor un cúmulo de la forma dineraria internacional diferente a la moneda nacional.

La predominancia del equivalente general internacional, sobre la moneda nacional, provocará una relación directa del circulante nacional con el circulante internacional. Esta equivalencia lógica, que ayuda a elevar el circuito de la moneda, provocando serios desajustes como inflación, devaluación, etc., es parte del endeudamiento externo contratado para el "financiamiento del desarrollo" en aras de la reproducción del capital. El equivalente general en su forma de divisa hegemónica quedará en las reservas del banco central y servirá para el intercambio de bienes de capital, bienes de consumo o para ser usado por las clases sociales pudientes; dicha moneda servirá para hacer frente al pago de la deuda externa. Pero por razones de soberanía nacional no circulará internamente y aunque la moneda nacional sea de curso forzoso, la moneda hegemónica será el punto de referencia en los precios internos de salarios y bienes.

El equivalente general internacional pasa a ser parte de las reservas de la banca central, pero es utilizado para salir al exterior en función de las necesidades de pago del país deudor con sus acreedores y para el pago de mercancías y así 
satisfacer las necesidades del proceso de acumulación interno del país.

El endeudamiento externo, flujo de dinero entre acreedores y deudores, permite el intercambio de mercancías en el proceso de cambio social; el cambio de los productos, tanto de medios de producción y la fuerza de trabajo

crea al mismo tiempo relaciones sociales determinadas de producción, donde entran los individuos en esta circulación de la materia. Las relaciones evolutivas de unas mercancías con otras cristalizan en determinaciones distintas del 'equivalente general', y de este modo el proceso de cambio es al mismo tiempo el proceso de formación del dinero. El conjunto de este proceso, que se manifiesta como el movimiento de diferentes procesos, es la circulación. ${ }^{14}$

El dinero, como un equivalente general, una vez que pasa a manos del deudor sigue cumpliendo las funciones de medio general de compra y de pago antes de cumplir las funciones de capital; cuando entra al proceso de producción y de circulación es el preciso momento en que deja de ser equivalente general en sus funciones de medio de pago y compra. Entonces la producción de mercancías se realiza en la circulación y el equivalente general adquiere la característica de capital.

El estudio del endeudamiento externo en los países subdesarrollados es importante porque

el dinero no es, en realidad, más que el instrumento para efectuar la compra y la venta (pero, ¿qué entienden ustedes por comprar y vender?) y el estudio del dinero forma parte de la ciencia de la economía política como la podría formar el de los navíos o el de las máquinas de vapor, o el de cualquier otro instrumento que sirva para facilitar la producción y la distribución de la riqueza. ${ }^{15}$

${ }^{14}$ Marx, Karl. Contribución a la Crítica de la Economía Política, Ediciones de Cultura Popular, México, 1974.

${ }^{15}$ Ibid. 


\section{Notas sobre el crédito y la función del capital en el proceso de internacionalización}

Antes vimos el papel que desempeña el equivalente general en su forma dineraria para intercambiar los productos. Ahora el equivalente general se convierte en función dineraria y en una función de capital. Veamos en seguida la secuencia del capital en un sistema crediticio, hasta la internacionalización de éste, en la división internacional del trabajo.

\section{Crédito de capital o bancario}

El sistema crediticio se perfecciona a medida que el intercambio de mercancías se desarrolla, y aparece la letra de cambio, sustituyendo la forma moneda dineraria oro. A este sistema Marx lo llama crédito de circulación, mismo que se va centralizando a través de las instituciones financieras.

Los bancos, al recibir fondos monetarios de capital ocioso congelado, se vuelven administradores al ritmo del crecimiento de la producción capitalista y del comercio mercantil. Por tanto, "un banco representa por un lado la centralización del capital dinerario, de los prestamistas, y por el otro la centralización de los prestatarios". ${ }^{16}$

El crédito que sirvió para sustituir el dinero como medio de pago se transforma en dinero o capital productivo y, posteriormente, en crédito de capital.

Si, por consiguiente, el crédito de circulación efectúa una sustitución del dinero efectivo, denominaremos el crédito en su función de transformar el dinero en la forma que sea, esto es, ya sea en efectivo o dinero de crédito, de dinero congelado en capital monetario activo: crédito de capital. Crédito de capital, precisamente, por que ésta transferencia es siempre transferida a aquellos que emplean el dinero como capital monetario mediante la compra de los elementos del capital productor. ${ }^{17}$

${ }^{16}$ Marx, Karl. El Capital, tomo III, vol. 7, p. 515.

17 Hilferding, R. El Capital Financiero, Ed. El Caballito, pp. 85-86. 
Crédito de capital y tasa de ganancia

El dinero como crédito de capital es puesto por los bancos a disposición del capitalista industrial y del capitalista comercial, agilizando así la producción y circulación de mercancías: el proceso global de la reproducción se amplía y en consecuencia hay una mayor rotación de capital.

La función de ambos capitales es obtener una ganancia a través de la realización de los valores en precios de producción. La ganancia es “...una expresión, peculiar al modo capitalista de producción..." ${ }^{18}$ Se obtiene una vez que la mercancía ha cumplido su fin; dicha ganancia objeto de la producción capitalista se interrelaciona con la función del crédito de capital. De ahí que las funciones del crédito sean las siguientes:

1. Necesaria formación del mismo para mediar la nivelación de la tasa de ganancia o el movimiento de dicha nivelación, en la cual se basa toda la producción capitalista.

2. Reducción de los costos de circulación.

3. Formación de sociedades por acciones.

4. Centralización de capitales. ${ }^{19}$

Más tarde, la ganancia global obtenida será correspondiente a cada capital, la ganancia será determinada por el tipo de interés; "...la parte de la ganancia que le corresponde al capitalista activo aparece ahora, en su carácter de ganancia empresarial [...] Por lo tanto, frente a él, el interés aparece como el mero fruto de la propiedad del capital..."'. ${ }^{20} \mathrm{La}$ división cualitativa de la ganancia media entre los diferentes capitalistas emerge de las diferentes formas de cómo se emplea el capital en el proceso global de la producción. En tanto que su división cuantitativa se relaciona con el precio del dinero.

$\mathrm{Al}$ analizar el papel del crédito en el proceso de acumulación, en su relación con el tipo de interés, encontramos que

${ }^{18}$ Marx, Karl. El Capital, tomo III, vol. 6, p. 271.

${ }^{19}$ Ibidem, tomo III, vol. 7, pp. 561-569.

${ }^{20}$ Ibidem, tomo II, p. 478. 
la división de ganancia media entre los diferentes capitalistas no es igual para todos. Es decir, para los capitalistas bancarios muchas veces el tipo de interés que obtienen por prestar su dinero a los capitalistas industriales o comerciales, puede ser mucho mayor que la ganancia empresarial o ganancia de fundador.

Como el tipo de interés varía poco en los sistemas capitalistas desarrollados y, en cambio, baja el nivel de beneficios, crece, en cierto grado, la parte del interés del beneficio total frente a la.ganancia del empresario; esto es, la parte de los capitalistas ociosos a costa de los activos, un hecho que, en verdad, está en contradicción con el dogma del tipo de interés decreciente, pero que concuerda con los hechos y, al mismo tiempo, es una causa de la influencia creciente y de la importancia del capital a interés, esto es de los bancos, y es una palanca importante para la transformación del capital financiero. ${ }^{21}$

\section{Crédito y crisis}

En la medida en que las crisis son inherentes al sistema capitalista, se manifiestan como crisis de sobreproducción. ${ }^{22} \mathrm{El}$ crédito cumple una función de "mediador" al ayudar al Estado a ampliar las fuentes de inversión y proseguir el proceso de acumulación al interior de sus fronteras; pero a su vez también permite que se dé el proceso de acumulación en el exterior, en la medida en que ambos procesos de acumulación forman parte de la acumulación, a nivel internacional, del modo de producción capitalista.

La relación que tiene el crédito de capital con las partes que forman la tasa de ganancia, y las funciones de aquél en un contexto de crisis, se señalan así:

Si se consideran los ciclos de rotación dentro de los cuales se mueve la industria moderna -estado de reposo, creciente animación, pros-

${ }^{21}$ Hilferding, R. op. cit.

22 Entendemos por crisis de sobreproducción cuando la oferta de mercancías supera a la demanda solvente y provoca reducción de la producción corriente. Hay baja en la tasa media de ganancia, y el capital recientemente acumulado ya no tiene condiciones de rentabilidad, volviéndose capital especulativo. 
peridad, sobreproducción, crisis catastrófica, estancamiento, estado de reposo, etc.... se descubriría que mayormente un bajo nivel del interés corresponde a los periodos de prosperidad o de ganancias extraordinarias, el ascenso del interés corresponde a la línea divisoria entre la prosperidad y su trastocamiento, mientras que el máximo del interés hasta el nivel extremo de la usura corresponde a la crisis. ${ }^{23}$

\section{Circuito de capital e internacionalización del capital}

Antes de pasar a las categorías de concentración y centralización del capital y su relación con el capital financiero internacional, es necesario hacer una pequeña pausa para recordar el ciclo del capital dinero en una economía cerrada. Ciclo que, en una economía mundial origina asimismo que se internacionalice. El desarrollo teórico será elaborado posteriormente por la escuela francesa contemporánea, entre los que destaca Christian Palloix. ${ }^{24}$

Las funciones del ciclo y su reproducción son desarrolladas posteriormente. No obstante que la fórmula para el ciclo del capital dinero se desprende desde el estudio de las funciones del dinero. La fórmula para el ciclo del capital dinero es D-M...P....M'-D'. La partícipación del capital en la fase de circulación o de producción determina sus propias características.

Las dos formas que adopta el valor de capital dentro de sus fases de circulación son las de capital dinerario y capital mercantil; su forma correspondiente a la fase de producción es la de capital productivo. El capital que en el transcurso de su ciclo global adopta y vuelve a abandonar estas formas, y que en cada una de ellas cumple la función correspondiente a dicha forma, es el capital industrial, en el sentido de que abarca todo ramo de la producción explotado en forma capitalista. ${ }^{25}$

${ }^{23}$ Marx, Karl. op. cit., p. 460.

24 Entre las obras principales de Christian Palloix destacan Las firmas multinacionales y el proceso de intemacionalización, (traducción de José Luis Alonso). Siglo XXI, Madrid. La Internacionalización del Capital, (traducción de Eduardo López García). Blume Ediciones, Madrid, 1975; Proceso de Producción y Crisis del Capitalismo, (traducción de Rafael Myre H.). Blume Ediciones, Madrid, 1979, 285 pp. ${ }^{25}$ Op. cit., tomo II, vol. 4, p. 59. 
En consecuencia, el capital industrial engloba formas funcionales que se suceden una tras otra; no son capitales autónomos, cuyo contenido de ramas sí es autónomo y separado entre sí.

El objetivo de capital industrial será cumplir con la función de capital, es decir, la creación y apropiación del plusproducto o plusvalor que se engloba en el modo de producción capitalista. El incremento que realiza el capital industrial aparecerá de nuevo como una forma general de equivalente. $\mathrm{Si}$ de aquí nosotros participamos del establecimiento de una economía mundial ${ }^{26}$ y de una división internacional del traba$\mathrm{jo}^{27}$ el capital industrial exige asimismo sus objetivos dados en una economía cerrada. La reproducción del capital se hace a nivel internacional.

Por tanto, si damos por hecho que el capital se internacionaliza y sus ciclos también, se observa que existe una relación intrínseca entre el capital mercantil, el capital dinerario y el capital productivo. Existe una relación estrecha entre los ciclos a nivel internacional donde el endeudamiento otorgado por los bancos vía Estado o industria tendrá una relación estrecha con su comercialización.

${ }^{26}$ Siguiendo a Bujarin, definimos la Economfa Mundial como " un sistema de relaciones de producción y de relaciones de cambio correspondientes que abrazan la totalidad del mundo" en: Bujarin, Nicolai I. La Economia Mundial y el Imperialismo, Cuadernos de Pasado y Presente, núm. 21, p. 42.

${ }^{27}$ Entendemos la división internacional del trabajo del mismo modo que Bujarin. Él señala la existencia de dos condicionantes: primera: "las condiciones naturales que se desprenden de la diversidad del medio natural en el cual viven los diversos organismos de producción; segunda: las condiciones sociales que se derivan de la diferencia del nivel de 'cultura' de estructura económica y el grado de desarrollo de las fuerzas productivas", p. 34. Amplía su definición cuando indica que ésta se define por el cambio internacional; " "esta interdependencia de los países en el terreno del cambio no es, en modo alguno, accidental; es más bien la condición necesaria de la evolución social posterior, mediante la cual el cambio internacional se transforma en un fenómeno regular de la vida social económica". Ibid. p. 39. 
De lo anterior es importante rescatar de la obra de Palloix tres aspectos en relación a la internacionalización del capi$\mathrm{tal}^{28}$

La internacionalización del espacio del ciclo del capital mediante la fórmula desarrollada del circuito del capital social:

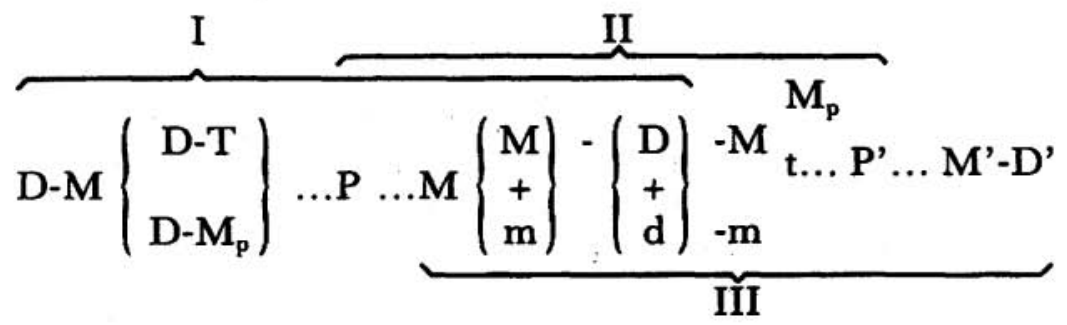

La observación del autor es que el desenvolvimiento de estos ciclos constituyen un fenómeno nuevo, principalmente para el ciclo del capital-dinero y el ciclo del capital productivo, confinados anteriormente de manera esencial en un espacio más o menos estrecho. Únicamente el ciclo del capital-mercancía, constituye desde los orígenes del capitalismo un ciclo que se desarrolla relativamente en el espacio internacional. "A nivel del ciclo del capital-dinero (D-M...P...M'-D'), donde se verifica la valorización del capital, puede extraerse directamente una idea de la valorización internacional del capital-dinero en forma de inversión internacional". ${ }^{29} \mathrm{De}$ aquí el carácter cada vez más internacionalizado del ciclo del capital-dinero y de la financiación: el mercado de eurodólares y su participación en el financiamiento de sectores productivos en países desarrollados y subdesarrollados, es un ejemplo de ello. "La valorización internacional del capital inicial obliga a recurrir cada vez más al crédito aplazado

${ }^{28} \mathrm{El}$ aporte de Palloix se verifica en la obra Las firmas multinacionales y el proceso de internacionalización. Para los fines de nuestro trabajo sólo tomaremos de este libro el capítulo V, que trata sobre la internacionalización del capital. Sus otros libros son: Proceso de producción y crisis del capitalismo y La Intemacionalización del capital, publicados por la Editorial Blume, p. 213.

${ }^{29}$ Ibid., p. 214. 
-en el transcurso de la rotación del capital-, crédito que se despliega igualmente en un espacio internacional", afirma Palloix. ${ }^{30}$

La internacionalización del capital, en su proceso de valorización: $\mathrm{D}-\mathrm{T}$ y $\mathrm{D}-\mathrm{Mp}$, indica que en la medida en que el dinero como capital es una relación trabajo, una relación social, está lanzando al mercado mundial una relación de un proceso de valorización.

En consecuencia, para que el acto D-T se internacionalice, para que se internacionalice el ciclo del capital-dinero como expresión del acto precedente, es preciso que previamente el ciclo del capital-mercancía - mediante el acto global de circulación Pc-, y el ciclo del capital productivo hayan conseguido hacer avanzar suficientemente sus elementos en el espacio internacional para que la fuerza de trabajo se convierta en una mercancía libre en todos los puntos de la economía mundial. Sólo así podrá valorizarse el capital. ${ }^{31}$

Por tanto, la valorización del capital aparece en la etapa del imperialismo. Y es la relación social a nivel mundial la que permite además el cumplimiento de la ley del valor en el ámbito internacional.

La internacionalización del ciclo del capital, y muy particularmente del ciclo del capital-dinero, permite la financiación en la política de crecimiento estratégico de las trasnacionales.

\section{Banca, trasnacionalización del capital y endeudamiento externo}

Concentración, centralización y acumulación.

Génesis de la banca trasnacional

Comencemos con los conceptos centrales de concentración, centralización y acumulación, tal como son desarrollados e interrelacionados por Marx en diferentes partes de $\mathrm{El} \mathrm{Capi-}$ tal, enfocándolos desde el punto de vista de nuestro interés. 30 Ibid., p. 216.

31 Ibid., p. 230. 
$\mathrm{Al}$ analizar la ley general de la acumulación capitalista, Marx retoma los métodos ya señalados en la Sección IV, "La Producción del Plusvalor Relativo" - la cooperación, la división manufacturera, etc. - , de su importancia èn el impulso que cobra la productividad del trabajo colectivo, para indicar que su introducción requiere de un grado considerable de expansión en la producción. De esta manera él señala:

Cierta acumulación de capital en manos de productores individuales de mercancías constituye, pues, el supuesto del modo de producción especificamente capitalista. Por eso, al analizar la transición del artesanado a la industria capitalista, tuvimos que suponer esa acumulación. ${ }^{32}$

Todos estos métodos que la producción capitalista utiliza para "fertilizar" el trabajo, como señala, son otros tantos métodos para aumentar la plusvalía y, en consecuencia, aumentar la fuente de acumulación, "La producción del capital por medio del capital". En otras palabras, se provocan impulsos ampliados que tienden a cambiar la composición técnica del capital, a favor de la parte constante del mismo. ${ }^{33}$

En relación con este problema que define la categoría concentración que, por otro lado ya ha usado al tratar el problema de la cooperación: ${ }^{34}$

Todo capital individual es una concentración mayor o menor de medios de producción, con el comando correspondiente sobre un ejército mayor o menor de obreros. Toda acumulación se convierte en medio al ser-

${ }^{32}$ Marx, Karl. El Capital, tomo I, vol. 3, cap. XXIII, Siglo XXI Editores, México 1975 , p. 776.

${ }^{33}$ Se hace énfasis en la composición técnica del capital para encuadrar el enfoque de la ampliación de las empresas. Debe recordarse que Marx plantea dos puntos de vista, desde los cuales se presenta la composición del capital: La composición-valor, determinada por la proporción entre el valor de los medios de valor de la fuerza de trabajo y la composición-técnica, expresada en la proporción que hay entre la masa de medios de producción y la cantidad de trabajo necesaria para ponerlo en movimiento. El vínculo entre ambas estaría expresado en la llamada composición-orgánica (composición valor, en tanto dependiente de la técnica). Veáse: Marx, Karl. El Capital, tomo I, vol. 3, cap. XXIII. Siglo XXI Editores. México, 1975, pp. 759-760.

${ }^{34}$ Ibid., vol. 2, cap. XI, p. 401. 
vicio de una nueva acumulación. Amplía con la masa acrecentada de la riqueza que funciona como capital, su concentración en las manos de capitalistas individuales y por tanto el fundamento de la producción en gran escala y los métodos de producción específicamente capitalistas. El incremento del capital social se lleva a cabo a través del incremento de muchos capitales individuales. ${ }^{35}$

Al continuar su análisis muestra cómo la acumulación de capital social no se realiza únicamente por la vía de la concentración que se dispersa en diferentes focos de acumulación y concentración relativos.

Esta dispersión del capital global de la sociedad en muchos capitales individuales y esta repulsión de sus partes integrantes entre sí aparecen contrarrestadas por su movimiento de atracción. No se trata ya de una simple concentración, idéntica a la acumulación, de los medios de producción y del poder de mando sobre el trabajo. Se trata de la concentración de los capitales ya existentes, de la acumulación de su autonomía individual, de la expropiación de unos capitalistas por otros, de la aglutinación de muchos capitales pequeños para formar unos cuantos capitales grandes. Este proceso se distingue del primero en que sólo presupone una distinta distribución de los capitales ya existentes y en funciones; en que, por tanto, su radio de acción no está limitado por el incremento absoluto de la riqueza social o por las fronteras absolutas de la acumulación. El capital adquiere aquí, en una mano, grandes proporciones porque allí se desperdiga en muchas manos. Se trata de una verdadera centralización, que no debe confundirse con la acumulación y la concentración. ${ }^{36}$

Como puede observarse, ambas categorías forman parte de un proceso dialéctico. No puede haber centralización sin concentración; mientras que la centralización es un elemento importante del proceso mas rápido acompañado de un aumento acelerado de la masa y tasa de plusvalor.

Ambas categorías siguen en su desarrollo diferentes fases de importancia para el tema que nos ocupa.

Al analizar la cooperación simple como punto de partida lógico e histórico de la producción capitalista, que luego me-

${ }^{35}$ Ibid., vol. 3, cap. XXIII, p. 777.

${ }^{36}$ Ibid., Edición del FCE, 1959, p. 529. 
diante un proceso pasará a la manufactura y a la gran industria, Marx toca el problema de la concentración:

El número de los obreros que cooperan, o la escala de la cooperación, dependerá por tanto, en un primer momento, de la magnitud del capital que el capitalista individual pueda desembolsar para adquirir fuerza de trabajo, esto es, del grado en que cada capitalista pueda disponer de los medios de subsistencia de muchos obreros.

Y lo mismo que ocurre con el capital variable, sucede también con el capital constante.

La concentración de masas mayores de medios de producción en las manos de capitalistas individuales es, pues, condición material para la cooperación de los asalariados, y el volumen de cooperación o la escala de la producción depende del volumen de dicha concentración. ${ }^{37}$

Veamos en esta serie de consideraciones, la primera forma que asume la concentración de capital en la empresa individual, de mayor concentración en el periodo manufacturero propiamente dicho.

En la descripción de esta etapa - siglo XVI al último tercio del XVIII- es importante recoger una categoría planteada por Marx y luego desarrollada por Hilferding, Lenin y Bujarin relacionada con nuestro trabajo: la combinación.

La manufactura, por último, así como en parte surge de la combinación de diversos oficios artesanales, puede transformarse en combinación de diversas manufacturas [...] A pesar de las diversas ventajas que presenta la manufactura combinada la misma no adquiere, sobre su propio fundamento, una verdadera técnica. Dicha unidad sólo surge cuando la manufactura se transforma en la industria maquinizada. ${ }^{38}$

Volviendo a las formas de concentración, es en este periodo en el que predomina la gran industria - subsumiendo la cooperación simple y ka manufactura como formas que aún subsisten - al que Marx se refiere cuando al hablar de la centralización, señala:

37 Todas las citas a partir de aquí son de la edición de Siglo XXI Editores. El Capital, México, 1975, tomo I, vol. 2, cap. XI, p. 401.

38 Op. cit., tomo I, vol. 2, cap. XII, p. 423. 
En la misma medida en que se desarrolla la producción y la acumulación capitalista, se desenvuelve también la competencia y el crédito, las dos palancas más poderosas de la centralización. Por lo demás, el progreso de la acumulación acrecienta la materia centralizable, esto es, los capitales singulares, mientras que la expansión de la producción capitalista crea aquí la necesidad social, allí los medios técnicos de esas imponentes empresas industriales cuya puesta en práctica está ligada a una centralización previa del capital. ${ }^{39}$

Aquí se producen dos fenómenos que nos interesa señalar: el aumento del tamaño de las empresas, por el proceso de centralización (condición para el desarrollo de las formas monopolistas) y la precipitación, como el mismo Marx indica, de los cambios en la composición del capital, que aumenta su parte constante a expensas de la variable.

Es a partir del último cuarto del siglo XIX - como han señalado Hilferding, Lenin y Bujarin - cuando esta forma de " "acumulación [...] se traduce por una acumulación de capital de ciertos patrones, opuestos los unos a los otros por la concurrencia [y] se ha transformado en el medio de acrecentar los capitales de las organizaciones patronales'. 40

Hilferding, partiendo del análisis marxista de la baja tendencial de la tasa de ganancia, que Marx considera " una expresión, peculiar al modo capitalista de producción, al desarrollo progresivo de la fuerza productiva social del trabajo",41 muestra cómo surge una contratendencia para evitar la supresión de la libre competencia, llevada a cabo mediante la "asociación capitalista".

Esta tendencia que nace, según Hilferding, en las esferas más desarrolladas del capital industrial, es coincidente en tal momento con los intereses del capital bancario. Su análisis de la competencia entre las empresas industriales, especialmente en las épocas de depresión y los intereses bancarios expresados en créditos y operaciones financieras productivas,

${ }^{39}$ Op. cit., tomo I, vol. 3, cap. XXIII, p. 779.

${ }^{40}$ Bujarin, N. I. La Economia Mundial y el Imperialismo. Cuadernos Pasado y Presente, op. cit., tomo III, vol. 6, cap. XIII, p. 271.

${ }^{41}$ Marx, Karl. op. cit., tomo III, vol. 6, cap. XIII, p. 271. 
lo lleva a demostrar cómo estos últimos, cualquiera que sea la empresa derrotada, siempre pierde.

Por eso, el deseo absoluto de la banca es la supresión de la competencia entre empresas en las que toman parte. Pero todo banco está también interesado en el mayor beneficio posible. En igualdad de condiciones, éste alcanzará de nuevo su mayor nivel con la completa supresión de la competencia en una rama de la industria. De ahí la aspiración de los bancos por crear el monopolio. Así, las tendencias del capital bancario convergen con las del industrial en el afán de suprimir la competencia. Pero, al-mismo tiempo, el capital bancario recibe cada vez más fuerza para conseguir esta meta, incluso contra la voluntad de empresas individuales que quizá prefiriesen la lucha de competencia, apoyadas en sus instalaciones especialmente favorables...42

Con tal "apoyo" del capital bancario y dentro del marco cíclico del capitalismo, las empresas tienden a las asociaciones como forma de contrarrestar la caída de la tasa de ganancia. Sus formas más genéricas son la combinación, que Hilferding recoge de Marx y define como "...la unión de aquellas empresas capitalistas, de las que una suministra la materia prima para la otra, y [...] de las uniones de empresas pertenecientes al mismo sector de la industria". ${ }^{43}$

El estudio de las categorías de concentración y centralización del capital, como antesala del capital financiero internacional en la división internacional del trabajo y en el marco del modo de producción capitalista, no ha terminado aún. Hoy día, las categorías estudiadas recobran mayor importancia al observar cómo la función del capital es obtener ganancias y por ello la transferencia de capitales hacia áreas más rentables, muestran el enorme endeudamiento en que cayeron los países de medianos ingresos. Bujarin señala lo siguiente:

Tras de todos estos cárteles y trust se ubican generalmente empresas que los financian, principalmente los Bancos. Este proceso de inter${ }^{42} \mathrm{R}$. Hilferding, pp. 210-211.

${ }^{43}$ Op. cit., p. 218. 
nacionalización, cuya forma más primitiva es el cambio internacional, ha provocado una internacionalización muy grande del capital bancario, que se transforma en capital industrial (por el financiamiento de establecimientos industriales), constituyendo de esta manera una categoría especial de capital financiero. ${ }^{44}$

\section{Conceptualización del conglomerado trasnacional}

La revisión histórica que ha tenido como centro las categorías de concentración y centralización (inciso anterior), nos permite acercarnos a una conceptualización del conglomerado trasnacional.

Al meditar sobre el método marxista, no resulta raro que al estudiar la fase de la gran industria maquinizada Marx haya dedicado una parte de su trabajo a la unidad productiva correspondiente a ese periodo: la fábrica. ${ }^{45} \mathrm{La}$ fábrica constituiría, para el caso, la unidad más simple, pero a la vez más compleja para estudiar las contradicciones entre concentración y centralización, patrones y obreros, capital constante y variable. Y, sobre todo, la línea continua histórico-genética que lleva del taller y luego de la fábrica capitalista a la trasnacional, "la unidad económica típica en el mundo capitalista" actual, como la califican Baran y Sweezy. ${ }^{46}$

Marx, en una genial previsión por la vía del método, atisba tal desarrollo al estudiar la Ley General de la Acumulación Capitalista, al señalar que

Hoy día, pues, la fuerza recíproca con que se atraen los capitales singulares y la tendencia a la centralización son más pujantes que nunca [...] y esto distingue de manera especial, la centralización de la concentración, que no es más que otro término para designar la reproducción en escala ampliada. ${ }^{47}$

${ }^{+4}$ Bujarin. op. cit., p. 76.

${ }^{45}$ Marx, Karl. op. cit., tomo I, vol. 2, Sección Cuarta, cap. XIII, parte 4, p. 511 .

${ }^{46}$ Baran, Paul. El Capital Monopolista (ensayo sobre el orden económico y social de Estados Unidos). México, Siglo XXI, Editores, 1971, p. 10.

${ }^{47}$ Marx, Karl. op. cit., tomo I, vol. 3, p. 779. 
Tal tendencia cristaliza a principios del siglo actual. Fenómeno perfectamente captado por Lenin en 1916: "El incremento enorme de la industria - decía - y el proceso notablemente rápido de concentración de la producción en empresas cada vez más grandes constituye una de las particularidades más características del capitalismo". ${ }^{48}$

Las discusiones sobre el tema, reiniciadas por Baran y Sweezy, han llevado - como planteó Rodolfo Banfi- “.... lograr unanimidad en la comprobación de que la concentración es un fenómeno típico de nuestro tiempo"'. Ello, no obstante, sin perjuicio de la competencia y contradicciones que se manifiestan, en contra de las tesis shumpeterianas que buscan una consolidación en lo que llaman la "despersonalización de la gran sociedad por acciones modernas", en orden a lograr una socialización espontánea o de aquellas otras que, mostrando un total desconocimiento del análisis marxista, intentan encontrar fallas en el mismo al insistir en la existencia de pequeñas empresas al margen de las trasnacionales ignorando su imbricación. ${ }^{49}$

Una primera caracterización que podríamos hacer, dentro del enfoque de nuestro trabajo de endeudamiento externo es constituir una resultante, una concreción del avance del modo de producción capitalista y de las necesidades que éste le plantea al desarrollo mismo de las fuerzas productivas, desarrollo que se manifiesta, como señalaba Hilferding "En que la misma masa de trabajo vivo pone en movimiento una masa cada vez mayor de medios de producción." 50

Esto nos lleva a un segundo aspecto relacionado con las trasnacionales; nos referimos al proceso de acumulación para enfrentar tal desarrollo. Si el propósito del capital es, como lo demostró Marx, reproducirse a sí mismo en escala ampliada, el logro de tal propósito por medio del proceso de

${ }^{48}$ Lenin, V.I. op. cit., p. 732.

${ }^{+9}$ Banfi, Rodolfo. "A propósito de 'El Imperialismo' de Lenin", en: Varios. Teoria Marxista del Imperialismo. Cuadernos Pasado y Presente, junio de 1973, p. 102.

${ }^{50}$ Hilferding, R. op. cit., p. 202. 
acumulación capitalista no sólo ha ido creando las formas productivas que le son necesarias, sino acomodándolas al creciente proceso de internacionalización del capital; como hemos visto, se inicia durante el siglo XIX, más tarde se interrumpe en los años comprendidos entre la gran depresión y la segunda guerra mundial y cobra auge inusitado a partir de 1945. El conglomerado trasnacional constituirá, en tal sentido, la forma recreada para enfrentar las nuevas situaciones, a partir de las formas de fusión y asociación correspondientes al periodo anterior.

El conglomerado trasnacional, por lo tanto, se encuentra representado por el proceso de acumulación de capital, con un desarrollo avanzado de las fuerzas productivas, donde las relaciones de producción ya no pertenecen a un contexto nacional, sino internacional.

Es decir, que la unidad de los ciclos: capital-dinero, capital-productivo, capital-mercancías - denominado capital financiero-,${ }^{51}$ unidos en el proceso de producción y circulación, expanden el movimiento de las relaciones sociales, las relaciones de clase a nivel mundial, en el seno de la valorización de capital.

El conglomerado trasnacional, a su vez, mantiene, defiende y desarrolla un frente teórico e ideológico para facilitar la valorización del capital. Es el poder del dinero y de los medios de producción, ${ }^{52}$ los que han venido a desarrollar una ideo-

${ }^{51}$ Cf. Hilferding, "Llamo capital financiero al capital bancario, esto es, capital en forma de dinero, que de este modo se transforma realmente en capital industrial", op. cit., pp. 253-254. Lenin, por su parte, corrige y amplía: "Esta definición no es completa, por cuanto no se indica en ella uno de los aspectos más importantes: el aumento de la concentración de la producción y del capital en un grado tan elevado, que conduce y ha conducido al monopolio. Pero en toda la exposición de Hilferding, en general, y en particular en los dos capítulos que precéden a aquél del cual hemos entresacado esta definición, se subraya el papel de los monopolios capitalistas. Concentración de la producción; monopolios, que se derivan de la misma; fusión o ensambladura de los bancos con la industria: tal es la historia de la aparición del capital financiero y lo que dicho concepto encierra"' op. cit., pp. 760-761.

52 Bernal Sahagún, Víctor Manuel. "La Publicidad: Economía y Política de los 'Medios Masivos"', en: Revista Problemas del Desarrollo, núm. 31 p. 140. 
logía dominante, cuyos instrumentos implicados en la esfera de la superestructura: organización escolar, medios de comunicación y militarización, coadyuvan en todo el proceso económico, social y político del sistema capitalista. Dichos mecanismos, de acuerdo con cada formación económico-soial, toman diferentes especificidades y son generales a todos los países.

Algunos autores argumentan la falta de base nacional de las trasnacionales, lo que desde luego tiene implicaciones de tipo político-económico. Rolfe y Damm, entre otros, señalan que en un futuro las fusiones internacionales y el mayor intercambio financiero tenderán a imposibilitar su identificación con un país, lamentando - de paso-que nuestra época aún no está preparada para abandonar el concepto de EstadoNación a causa de los rescoldos teóricos de Smith y Ricardo en el planteamiento de la inmovilidad de los factores productivos. ${ }^{53}$

$\mathrm{El}$ análisis del proceso de acumulación a nivel mundial, sus correspondientes desplazamientos de un país a otro que se convierte en integrador del sistema imperialista y los datos mismos, algunos de ellos mencionados a manera de ejemplo en la parte anterior, nos permiten rechazar tal posición. Es evidente, como indica Theotonio Dos Santos,' que

lo que hoy se llama empresa multinacional no son necesariamente corporaciones que pertenecen a capitalistas de muchas naciones, ni tampoco que son dirigidos por capitalistas o gerentes de muchas naciones. A pesar de que tienen una política internacional, ellas operan más bien desde una base nacional. ${ }^{54}$

Rolfe y Damm pretenden ignorar, sin duda, que a una mayor internacionalización del capital, han correspondido nuevas

${ }^{53}$ Cf. Rolfe, S. y Damm, W. The Multinational Corporation in the World Economy. Praegers Publishers Inc., Nueva York, 1970.

54 Dos Santos, Theotonio. "La Corporación Multinacional", en varios, Problemas del Subdesarrollo Latinoamericano. Ed. Nuestro Tiempo, México, 1973. Véase también Levinson, Charles. Capital, Inflation and the Multinationals. Macmillan, Nueva york, 1971. 
formas de dominación en las que se produce una modificación en el Estado mismo y en la estructura de las clases.

Aun con una base nacional - hecho cuyo reconocimiento permite un mejor análisis- las trasnacionales han venido a integrar, en las formaciones sociales en que funcionan, un bloque de poder con las fracciones de la burguesía nacional y los elementos dirigentes del llamado Estado democrático o militar, con una evidente hegemonía de aquellas. ${ }^{55}$

\section{El capital financiero y el endeudamiento externo}

La piedra angular de la historia de la economía política en los últimos tiempos es la influencia del capital financiero internacional y su internacionalización en el ámbito de la economía global. Su nacimiento, ubicado entre 1870-1914, y su crecimiento en el transcurso del siglo $\mathrm{XX}$, acompañado de dos crisis mundiales no avecinan, indiscutiblemente, su muerte. Todo lo contrario: un alto grado de fortalecimiento será el parámetro para el inicio del siglo XXI con nuevas particularidades. Por ello, el proceso de reordenación que ha sido comandado por el capital financiero internacional en el proceso de la financiación de la reproducción del capital en los países desarrollados y subdesarrollados, aparecerá con mayor profundidad en el marco de un proceso dialéctico de la acumulación internacional.

La sorpresiva forma de revelarse el capital financiero internacional en la década de los años setenta, vía la banca trasnacional, el mercado del eurodólar y el desarrollo de centros financieros internacionales en la periferia, invocan a profundizar teóricamente el proceso de concentración y centralización suscitado después de la segunda guerra mundial. Quizás uno de los elementos más importantes en el análisis de la economía política es el bien articulado sistema monetario internacional, creado en Bretton Woods, que permitió por varios

${ }^{55}$ Véase Boron, Atilio. "El Problema del Aparato de Estado en el Capitalismo Contemporáneo: Notas Preliminares para una Investigación"' (manuscrito) Quito, Ecuador. XII Congreso Latinoamericano de Sociología, noviembre de 1977. 
años la liquidez del sistema monetario internacional y el déficit de la cuenta corriente del país hegemónico, así como el mantenimiento de los tipos de cambio fijos. Lo que indujo a algunos estudiosos a suponer que las empresas multinacionales o grandes monopolios eran la forma representativa del capital monopolista de estado. ${ }^{56}$

Posterior a la contienda bélica, el estancamiento de las ciencias sociales oscureció la relación intrínseca del capital financiero internacional. Quizás la articulación perfecta e imaginaria con la que nació el sistema monetario internacional de Bretton Woods profundizó la relación del capital bancario con el industrial. No es sino hasta principios de la década de los años setenta cuando se retoman de nueva cuenta los estudios de Lenin, Hilferding y Bujarin ${ }^{57}$ para vislumbrar la incidencia de la internacionalización del capital-dinero, vía la banca trasnacional en el sistema financiero internacional.

Pero no por ello quiere decir que la banca y las empresas trasnacionales hayan quedado olvidadas durante los años cuarenta y cincuenta, puesto que, si bien el sistema monetario oficial es importante de 1940 hasta 1970 es porque la canalización de los préstamos al proceso de reproducción del capital, se realiza vía los empréstitos de carácter oficial multilateral y bilateral a las empresas multinacionales subsidiarias en los países subdesarrollados bajo la hegemonía del capital financiero internacional de origen estadounidense. ${ }^{58}$

El despegue del mercado de eurodivisas estuvo dirigido a lograr la reproducción del capital en el proceso de acumulación y valorización a nivel internacional evadiendo el orden jurídico. Este mercado debe ser relacionado con el desarrollo de la necesidad de financiamiento de las empresas estadounidenses, en una situación de restricción de crédito entre

\footnotetext{
${ }^{56}$ Baran, Paul y Paul Sweezy. op. cit.

57 Véase Estevez, Jaime y Samuel Lichtensztejn. Nueva Fase del Capital Financiero (elementos teóricos y experiencias en América Latina) CEESTEM-ILET Editorial Nueva Imagen, México, 1981.

${ }^{58}$ Lo anterior se desarrollará con mayor amplitud para el caso de México en el capítulo 4 .
} 
1963 y $1968 .^{59}$ Proceso estimulado por el aumento de los préstamos comerciales que relacionaban a las empresas multinacionales con las economías subdesarrolladas. No es sino a partir de 1974 que el mercado del eurodólar comienza a desempeñar su papel de reciclaje de los excedentes petroleros. Esta función permitió un desarrollo muy importante de los mercados privados de capital. ${ }^{60}$ Posteriormente, en los años setenta, los centros financieros internacionales aumentaron la flexibilidad y libertad de las operaciones bancarias y comerciales de los bancos y de las empresas trasnacionales en el mercado internacional, utilizando estas bases financierocomerciales menos reguladas y controladas que las de los países más desarrollados. ${ }^{61}$

Por ello, el estudio del endeudamiento nos interesa, ante todo, en razón de su articulación con el modo de producción capitalista. "Por el hecho de que la moneda constituye uno de los engranajes del capitalismo; su papel depende de sus funciones en el conjunto de las relaciones económicas que caracterizan el capitalismo"'.62

Reseñaremos ahora algunas aseveraciones que consideramos necesarias para el estudio del endeudamiento.

59 "'Las disposiciones de la política monetaria estadounidense instituidas para poner fin al déficit de la balanza de pagos de ese país han provocado una completa reestructuración de los circuitos internacionales de financiamiento. Mientras que el financiamiento de la internacionalización se efectuaba hasta entonces en el propio Estados Unidos por el Impuesto de Igualización de Intereses (IEI), el Programa voluntario de restricción de crédito al exterior (VFCRP) y el Programa de Inversión Extranjera Directa (FDIP), se instó a las compañías a recurrir a préstamos en el extranjero (sobre todo FDIP) y a los bancos a ofrecer sus servicios desde sus oficinas en el extranjero (VFCRP, más especialmente)"'. Véase Andreff, Wladimir y Oliver, Pastre. "La Génesis de los bancos multilaterales y la expansión del capital financiero internacional" en Estevez y Lichtensztejn. op. cit., p. 90. ${ }^{60}$ Paniagua Ruiz, Rafael. Prologómenos para una teoría dé los límites financieros del Estado: problemas de la deuda y crisis financiera, Cuadernos Universitarios, núm. 30, Universidad Aut6́noma Metropolitana-Iztapalapa, México, 1985, p. 117.

61 Gorostiaga, Xavier. Los Centros Financieros Internacionales en los Paises Subdesarrollados. ILET, México, 1977, p. 21.

${ }^{62}$ De Brunhoff, Suzanne. Teoría Marxista de la Moneda. Ediciones Roca, México, 1975. 
Para estudiarlo, es necesario integrar la teoría del dinero y la teoría de la producción capitalista. Esto se logra con el estudio de las modalidades de la financiación del capitalismo. El problema de la financiación no es más que un problema financiero: el de la utilización de disponibilidad monetaria en proporciones adecuadas. De Brunhoff manifiesta que: “...existen mecanismos específicos de financiación, que se desarrollan al mismo tiempo que la producción capitalista, que forman el 'sistema de crédito', que Marx distingue del 'sistema monetario"'. ${ }^{63}$

En el caso concreto de nuestra investigación, partimos del estudio del crédito, propio del modo capitalista de producción. El dinero-crédito desempeña un papel significativo en la producción capitalista. La teoría marxista del dinero comienza, pues, por la determinación de la "forma equivalente general", corresponden a funciones del dinero complementarias entre sí, a un tiempo diferente y necesariamente intervinculadas, cuyo juego combinado es lo único que conserva $y$ reproduce la forma equivalente general.

Podemos ampliar la teoría del dinero a un contexto internacional y, especialmente, según lo ha desarrollado Palloix, mediante su fórmula del ciclo del capital social.

Pero los cambios de la década de los años setenta implican una articulación diferente del sistema capitalista mundial. El capital financiero se erige como hegemónico en el fenómeno de la mundialización y trasnacionalización de la economía, articulando la internacionalización de la producción ocurrida desde los años cincuenta.

La década de los años ochenta consolidó los circuitos nacionales al circuito financiero internacional con la participación hegemónica de la banca trasnacional, el Banco Mundial y el FMI. Parecería ser una carrera para lograr el primer lugar en la alborada del siglo XXI.

$\mathrm{El}$ análisis del financiamiento de la reproducción del capital aparentemente es visto con suma claridad. Sin embargo, 
hay que tomar varios elementos para entender por qué dicho ciclo de capital, en su forma de capital-dinero, entra en crisis y, asimismo, las causas que lo definen:

a) El dinero para valorizarse a nivel internacional descansa en el proceso de circulación, cuando la mercancía se realiza en la oferta y la demanda.

b) Las condiciones del mercado estarían determinando el tipo de interés, resultado de la división de la ganancia media. Sea ésta cuando está en ascenso o en su tendencia descendente.

c) La competencia entre los prestamistas y prestatarios estaría ligada a dicho tipo de interés.

d) El capital de préstamo es tomado por el Estado capitalista o por el capitalista y éste refluye a sus acreedores una vez ya valorizado. Otras veces dicho capital no se valoriza sino que se atesora o se convierte en consumo improductivo.

e) Sin embargo, habría que partir de que el financiamiento tiene por objeto la valorización. Pero ¿qué pasa cuando dicho proceso se obstaculiza como resultado de problemas en los circuitos de la producción y de las mercancías? Sobre este punto Suzanne De Brunhoff dice:

aún cuando la crisis general no sea un fenómeno monetario, la crisis financiera representa un papel en la coyuntura global, pero su acción es, principalmente, de orden financiero: al poner provisionalmente al sistema de crédito en condición de no servir, reconstituye su base monetaria y le da la posibilidad de servir nuevamente a la financiación de la reproducción capitalista ${ }^{64}$

\section{Sistema financiero internacional y endeudamiento externo}

Durante la segunda mitad del siglo XX el sistema monetario internacional, en su conjunto, ha estado determinado por las

${ }^{64}$ De Brunhoff, Suzanne. La Concepción Monetaria de Marx. Ediciones del Siglo, Buenos Aires, 1973, p. 112. 
políticas monetarias de los organismos financieros y el fortalecimiento de los bancos trasnacionales en el mercado internacional de capitales.

En esta etapa las categorías de concentración y centralización se manifiestan en los bancos oficiales como el Banco Mundial y el Banco Interamericano de Desarrollo, el Eximbank y la AID. En el caso de México donde el poder del país hegemónico, Estados Unidos, es determinante debido a su alto número de votos, basado en cuotas, y el poder de veto en los créditos otorgados. Es a través de estos organismos que en un principio, después de la segunda guerra mundial, la financiación de la producción a nivel global estará orientada en función de las necesidades del capitalismo. El desarrollo paralelo de bancos pertenecientes al conglomerado trasnacional aparentemente fomentó otro tipo de concentración y centralización de capital diferente al de los bancos oficiales multilaterales y bilaterales. Sin embargo, los bancos trasnacionales y oficiales formaron la constelación de poder en cuanto a la disposición, disponibilidad y canalización del financiamiento de la acumulación. Donde el equivalente general servirá para el intercambio de bienes y servicios en aras del gran capital. Por lo tanto, el equivalente general participa con sus funciones propias sólo en la esfera del sistema capitalista.

Con el fortalecimiento de la banca trasnacional y el crecimiento de la intermediación financiera a nivel internacional, se hicieron necesarios cambios en los planteamientos elaborados en 1944 que permitieron incrementar y agilizar la reproducción del capital. ${ }^{65}$ Ello se demuestra porque uno de los problemas al que se debió enfrentar el sistema monetario internacional fue a la rigidez establecida de esos principios, que no permitían agilizar el proceso de acumulación y la reorganización de las fuerzas productivas, cuyos cambios eran notables en la composición orgánica de capital. El equivalente general ayudará en los años setenta a facilitar la recesión de los países desarrollados y permitirá el intercambio de sus ${ }^{65} \mathrm{Al}$ respecto, véase Chapoy, Alma. Ruptura del Sistema Monetario Internacional. IIEc-UNAM, México, 1983. 
productos a través de los países subdesarrollados. Luego, la financiación de sectores productivos en el Tercer Mundo facilitará la valorización del capital y con ello una centralización de ganancias a favor del gran conglomerado trasnacional.

Entre las reformas más importantes se encuentran la suspensión de la convertibilidad del dólar estadounidense al oro; la transformación de los tipos de cambio fijos a un sistema flexible y la evolución de los mercados internacionales de capitales: ${ }^{66}$

Uno de los problemas al que se enfrentaron los países después de la segunda guerra mundial fue la inestabilidad del sistema de reserva en el sistema financiero internacional. Por ello en la conferencia de Bretton Woods de 1944 se creó el FMI. Sin embargo, la inhabilidad para adecuar el crecimiento de la liquidez internacional fue demostrado a mediados de la década de los años sesenta.

A finales de 1969, justo antes de la primera colocación de los derechos especiales de giro (DEG), el oro era aún el principal componente de las reservas. Oficialmente las reservas en oro representaban el $40 \%$ del total de las reservas internacionales, 79 mil millones de dólares, mientras que otras reservas monetarias (denominadas en su mayoría en dólares de Estados Unidos) y las posiciones del tramo de oro del Fondo, constituían el 42 y el $9 \%$ respectivamente.

El crecimiento del comercio mundial y de pagos durante este periodo hizo que la proporción de reservas de importación de todos los países cayera de $48 \%$ en 1959 a $28 \%$ en 1969 . Para Estados Unidos la proporción cayó de $122 \%$ en 1959 a $41 \%$ en 1969 , reflejando una redistribución de reservas de Estados Unidos a otros países industriales. ${ }^{67}$

${ }^{66}$ Véase: International Monetary Fund, Staff Studies for the World Economic Outlook by the research Department of the International Monetary Fund, agosto de 1987. Washington, D. C.

${ }^{67}$ International Monetary Fund, The Role of the SDR in the International Monetary System Occasional Paper, núm. 51, Washington, D. C., marzo de 1987. México, octubre de 1981. Montgue, Yudelman. "El crédito agrícola del Banco 1974-1984", en Finanzas y Desarrollo, vol. 2. 
Los DEG se crearon con la finalidad de ayudar a la liquidez del sistema monetario internacional, pero fueron insuficientes. Para 1968 las reservas de oro en Estados Unidos cubrían únicamente dos tercios de los pasivos en manos de poseedores oficiales y extranjeros. Ante tal panorama fue necesario suspender la convertibilidad oficial del dólar frente al oro en agosto de 1971.

Si bien en el periodo de la posguerra la moneda dólar se había convertido en la clave del sistema monetario internacional, al tener una equivalencia de 35 dólares por onza de oro. El $70.1 \%$ de las reservas oro mundiales en poder de Estados Unidos en dicho periodo propiciaron que al dólar se le viera " $\tan$ bueno como el oro". Por ello la circulación de los capitales empezó a darse en gran parte en dólares y muchos países optaron por tener esta divisa como parte de su reserva monetaria bajo los lineamientos del FMI.

Siendo éste uno de los cambios estructurales más importantes del sistema monetario internacional. Los años 1970 y 1971 fueron marcados por un déficit de la balanza de pagos de Estados Unidos provocando una fuerte devaluación del dólar frente a las monedas europeas. Lo que originó un cambio drástico en las finanzas internacionales.

Otra innovación fue el rompimiento de los tipos de cambio fijo y una mayor flexibilidad de éstos. En diciembre de dicho año se estableció el Acuerdo Smithsoniano con objeto de evitar drásticas devaluaciones de las monedas europeas frente al dólar estadounidense. Esto fue temporal, muchos países pusieron sus monedas a "flotación" en marzo de 1973.

$\mathrm{El}$ crecimiento del sistema financiero internacional de los mercados de crédito, en particular aquellos activos y pasivos depositados en grandes bancos, fue otra novedad. El crédito privado vino ampliamente a los prestatarios oficiales. $\mathrm{Mu}$ chos gobiernos incrementaron sus reservas con préstamos de bancos comerciales y fuentes privadas. El desarrollo del mercado offshore o eurocurrency y las emergencias del mercado de eurobonos fue la principal característica de la década de los años setenta. 
Por último, el incremento de monedas diferentes al dólar en las reservas oficiales de los países propició que los activos en dólares cayeran de $80 \%$ en 1976 a $65 \%$ en 1984 , mientras que el marco alemán creció de siete a $12 \%$ y el yen japonés pasó de uno a $5 \%$ en el mismo periodo.

En los años ochenta los organismos internacionales no han realizado cambios importantes en su estructura y funcionamiento. La mayor parte de sus actividades se ha concentrado en "resolver" el problema de la deuda externa de los países del Tercer Mundo y en promover programas de ajuste. Estos organismos, en especial el FMI, han mostrado inflexibilidad y falta de originalidad. Sus políticas han sido totalmente ortodoxas, basadas en principios monetaristas y en una política económica neoliberal, cuya condicionalidad ha sido muy fuerte, imponiendo programas de austeridad a los países endeudados.

Existe una condicionalidad cruzada porque no es sólo el FMI y el BM sino también la banca trasnacional quienes indirectamente condicionan la política de los países endeudados. En los recientes acuerdos económicos internacionales la importancia de los problemas de la deuda externa de los países subdesarrollados es darle un tratamiento bilateral a la deuda en el marco de un mayor ajuste interno para mejorar el déficit de la balanza de pagos y reducir las tasas de inflación a nivel interno. 


\section{POLÍticA DE DEUDA EXTERNA}

Hemos dividido la política de endeudamiento en tres etapas. ${ }^{1}$ La primera, de los años cuarenta hasta finales de los sesenta. En ésta encontramos un primer momento, donde la política de endeudamiento será utilizada en aquellas inversiones necesarias para la expansión del capitalismo internacional. Otro sería el comprendido entre los primeros años del llamado periodo de estabilización hasta finales de los sesenta. Por ello, esta etapa se llama del despegue económico al desarrollo estabilizador.

La segunda etapa abarca de principios de los años setenta hasta la antesala de la "crisis financiera" que transcurre simultáneamente con el resquebrajamiento del sistema monetario internacional y la crisis global del sistema capitalista manifiesta en el aumento de los precios internacionales del petróleo y el fortalecimiento del mercado del eurodólar. En el ambiente interno se manifiesta el enfrentamiento entre la burguesía nacional y el Estado. La lucha por un modelo trasnacional se basa en la disputa de los grupos sociales vinculados a los intereses más poderosos por tomar el poder y dar pie al tránsito sin violencia social de una mayor integración con el proceso de acumulación internacional. La necesidad de recurrir al ahorro externo se hace evidente en el sexenio echeverrista. Sin embargo, la respuesta negativa por parte de la burguesía, ante la necesidad de salvar el proyecto que lo enriqueció, termina con la devaluación de 1976 coinci-

${ }^{1}$ La primera etapa coincide con el predominio de los organismos financieros internacionales multilaterales y bilaterales; en la segunda, de los años sesenta, aparecen los bancos privados internacionales. En la tercera etapa coinciden, en el tiempo histórico, lenguaje y discurso del deudor con el objetivo del acreedor. 
diendo con el fin del periodo de estabilización. Iniciándose así la petrolización de la economía nacional acompañada del boom petrolero a nivel internacional. Esta fase la denominaremos del "desarrollo compartido" a la "alianza para la producción".

La tercera comprende de la "crisis de liquidez" al proceso de "desfinanciamiento" del país. El quiebre del creciente endeudamiento dará soluciones de corte monetarista. Las alternativas de solución a la deuda externa las dictará el Fondo Monetario Internacional (FMI). Por ello el gobierno las plasmará en un lenguaje propio en los siguientes planes: Plan Nacional de Desarrollo 1983-1988 (PND), el Programa Inmediato de Reordenación Económica (PIRE); Pacto de Solidaridad Económica (PSE). La política de endeudamiento externo estará canalizada a la renegociación de la deuda y al pago de ella, mediante innovaciones en el lenguaje financiero, capitalización de pasivos (swaps), y los Bonos "cupón cero".

\section{Del "despegue económico" al "desarrollo estabilizador"}

En esta etapa de estudio, la política de endeudamiento externo del Estado mexicano es muy importante por su consolidación frente al proceso de financiación de la reproducción de capital a nivel interno; el Estado se consolida frente a la burguesía nacional como la principal entidad autónoma con capacidad para delinear el inicio del desarrollo del capitalismo nacional. Sin lugar a dudas, el Estado frente al proceso de financiamiento de la acumulación irá tomando en cuenta, poco a poco, a los recién creados organismos financieros internacionales como el Banco Mundial (BM) y el FMI subordinada al nuevo sistema financiero internacional, a través de la divisa dólar y en el seno del FMI. ${ }^{2}$

${ }^{2}$ Cardero, María Elena. Patrón Monetario y Acumulación en México (Nacionalización y Control de Cambios), Siglo XXI Editores, México, 1984. 
La política de deuda pública del gobierno mexicano durante este periodo se enmarca en los lineamientos de la estrategia del "desarrollo estabilizador". Los objetivos de dicha política $^{3}$ fueron garantizar la solidez de la moneda a un tipo de cambio fijo y combatir las presiones inflacionarias; alcanzar un crecimiento económico superior al $6 \%$ anual como promedio; impulsar la industrialización y aumentar la eficiencia productiva; corregir y atenuar desequilibrios en el desarrollo regional y en las diversas ramas de la actividad; lograr mayor equidad en la distribución del ingreso nacional. El crecimiento del Producto Interno Bruto (PIB), en términos reales, logró ser del $46 \%$ en el periodo. ${ }^{4} \mathrm{La}$ estrategia de desarrollo que se siguió estuvo basada en financiar dicha política con apoyo de endeudamiento externo.

Nacional Financiera, en su publicación La economía mexicana en cifras, ${ }^{5}$ nos muestra un balance de la función del crédito externo en el marco de la política "estabilizadora". De 1960 a 1969 entró por concepto de créditos del exterior la suma de 1982.9 millones de dólares; en el mismo periodo los intereses sobre deudas oficiales fueron de $\mathbf{8 4 0 . 6}$ millones mientras por concepto de amortización se pagaron 3430.6 millones de dólares. Ambas cifras suman la cantidad de 4771.2 millones de dólares. La sangría de capitales hacia el exterior, sólo por el uso del crédito externo, implicaría una depauperación de la clase trabajadora y califica la actividad económica de México como lo suficientemente "rentable" y al país, por consiguiente, sujeto de crédito en los mercados internacionales.

Esto explica por qué México, a mediados de los años sesenta, obtuvo financiamiento de Francia, Holanda, Alemania y Canadá. "Por primera vez en 50 años, México tuvo acceso al mercado internacional abierto de valores. Los bo-

${ }^{3}$ Secretaría de Hacienda y Crédito Público y Secretaría de la Presidencia. México a través de los Informes Presidenciales. "La Hacienda Pública", vol. IV, tomo 2, México 1976, p. 794.

${ }^{4}$ Ibid. El periodo de estabilización se enmarca entre 1954 y 1976.

${ }^{5}$ Nacional Financiera. La economía nacional en cifras. 
nos de los Estados Unidos Mexicanos para fomento económico se colocaron de inmediato y pronto alcanzaron una cotización que han mantenido por encima de su valor nominal' ${ }^{6}$ Por otro lado, el $20 \%$ de los créditos controlados a partir de 1960 eran amortizables en plazos de 5 a 10 años; el $80 \%$ restante estuvo contratado con vencimiento de 10 a 40 años; la mitad de los créditos devengaron $6 \%$ de intereses y solo un $7.9 \%$ alcanzó tipos de interés ligeramente superiores al $6.5 \% .^{7}$ Sin embargo, la incertidumbre internacional, la especulación con el oro, el alza desproporcionada de las tasas de interés, el debilitamiento del dólar y el déficit de la balanza de pagos de Estados Unidos condujeron, particularmente a finales de la década, a un encarecimiento del crédito de tipo oficial y privado.

Las reservas del Banco de México a principios de 1960 eran de 424.6 millones de dólares con disponibilidad en el extranjero de 345 millones. Para 1970, la reserva de oro, plata y divisas ascendía a 762 millones, incluyendo 47.4 millones de derechos especiales de giro; casi $55.72 \%$ superior a $1960 .{ }^{8} \mathrm{La}$ estabilidad de la moneda estuvo respaldada por 500 millones de dólares en apoyo secundario al peso mexicano, discriminados de la siguiente manera: 100 millones de conformidad con los acuerdos de asistencia monetaria recíproca de la Tesorería de Estados Unidos; 130 millones con el Sistema de Reserva Federal de la misma nación; 270 millones de los derechos normales de giro en el FMI. El respaldo adicional se elevó luego a 600 millones, cuando se produjo el aumento de 270 a 370 millones de dólares por la cuota de nuestro país en el organismo internacional. ${ }^{9}$

La política gubernamental usó el endeudamiento externo para proporcionarse ingresos puesto que la política tributaria no los obtuvo de las ganancias del gran capital. Por un lado, se logró que los recursos provenientes del impuesto a

\footnotetext{
${ }^{6}$ SHCP y SP. op. cit., p. 702.

${ }^{7}$ Ibid.

${ }^{8}$ Nacional Financiera. La Economía Mexicana en Cifras.

9 Op. cit., p. 783.
} 
la renta aumentara el número de causantes, de 5399622 en diciembre de 1964, hasta 10174229 a finales de 1969, con una tasa de crecimiento promedio de $13.9 \%$. Pero

el propio gravamen contribuyó a redistribuir el ingreso a favor del capital, al otorgar un tratamiento preferencial a los ingresos personales provenientes de esa fuente. Por otro lado, $[\ldots]$ el impuesto sobre utilidades de las empresas [proporcional] lo hizo en $10.7 \%$ y el gravamen sobre productos de capital en un cuatro por ciento. ${ }^{10}$

De este modo, la "reforma fiscal", al apoyarse principalmente en la imposición indirecta, produjo una de las cargas tributarias más bajas y altamente regresivas del mundo. Hay quienes señalan que los gobiernos de México han

recurrido al endeudamiento a pesar de que es nocivo para la economía nacional, porque las esferas gubernamentales aceptan cualquier riesgo con tal de mantener los privilegios o en todo caso en enfrentarse a los grupos reales de poder, constituidos por una reducida oligarquía que sí posee canales, tanto económicos como políticos por los cuales manifiestan su descontento. ${ }^{11}$

\section{Por su parte el mismo gobierno señala:}

Los gastos efectivos del gobierno federal han llegado a superar a los ingresos ordinarios casi en un $80 \%$ en los últimos años; paralelamente, el endeudamiento ha contribuido con más de los fondos necesarios para inversión, con una contribución creciente del crédito externo junto con los intereses, los pagos por servicios de la deuda externa absorbieron el $22 \%$ de los ingresos totales de divisas en cuenta corriente en 1967, lo que, junto con las remesas de utilidades de la inversión extranjera directa, colocó al país en cerca de lo que las instituciones

${ }^{10}$ Retchkiman, Benjamín. "La reforma fiscal en México", en Problemas del Desarrollo, Instituto de Investigaciones Económicas, núm. 19, p. 93. El autor cita a Francisco Javier Alejo y otros. ¿Crecimiento o desarrollo económico? Sep-Setentas, México, 1971; y a Ifigenia Martínez. "La evolución del sistema tributario mexicano y las reformas 1972-1973", en Comercio Exterior, México, enero de 1973. ${ }^{11}$ Retchkiman, Benjamín. "Política Fiscal Mexicana", en Problemas del Desarrollo, Instituto de Investigaciones Económicas, núm. 24, noviembre 1975-enero 1976, México, p. 87. 
financieras internacionales llaman vagamente "límites de seguridad", la situación del gobierno federal parece un poco más delicada, ya que el endeudamiento neto aportó casi el $30 \%$ del financiamiento de su inversión en 1960 , el $63 \%$ en 1954 y el $70 \%$ en $1968 .{ }^{12}$

Sin embargo, el presidente Gustavo Díaz Ordaz resume en el Segundo Informe de Gobierno la política de endeudamiento externo de la siguiente forma:

La capacidad de endeudamiento externo ha crecido, y probablemente seguirá creciendo, a medida que nuestra actividad productiva incremente su demanda de recursos. El buen crédito de México se debe a su estabilidad política, a la prosperidad de su economía y a la escrupulosa observancia de sus compromisos internacionales. En segundo lugar, al igual que la inversión extranjera directa, el crédito externo es factor complementario de un insuficiente ahorro nacional. La deuda se documenta a plazos cada vez más largos y con tasas de interés lo más bajo que permite el mercado. En tercer lugar, los recursos obtenidos se emplean para financiar obras productivas, que dejan un remanente de nueva riqueza en el país. Nunca se utilizan para financiar gastos corrientes. ${ }^{13}$

Esta política de endeudamiento externo fue un mecanismo más en el desarrollo estabilizador de una política económica altamente dependiente de la economía estadounidense, con objetivos claros bajo el programa de la "Alianza para el Progreso": mejorar la capacidad de compra e impulsar programas de carácter social para aliviar las presiones existen: tes, impulso que se acrecentó con la corriente de préstamos que caracterizó a la época, así como ante la emergencia de las trasnacionales en el panorama económico general del capitalismo. Por ello se dice: "en los círculos más liberales y avanzados, que se preocupaban sinceramente por un auténtico plan de desarrollo económico latinoamericano, la Alianza

${ }^{12}$ Alejo, Francisco Javier y otros. ¿Crecimiento o desarrollo económico? SepSetentas, México, 1971, citado en Retchkiman "La reforma fiscal en México", en Problemas del Desarrollo, núm. 19, pp. 103-104.

${ }^{13}$ SHCP y SP. op. cit., p. 730. 
fue reconocida de inmediato como una alternativa ideológica al marxismo, que ya había logrado triunfar en Cuba". ${ }^{14}$ Bajo el velo de la "Alianza para el Progreso" las corporaciones trasnacionales penetraron hondamente en la industrialización nacional al abrigo del Estado, quien concedió múltiples facilidades.

Esta forma de crecimiento económico propició una distorsión en la distribución del ingreso y del consumo, facilitando la fuga de capitales al exterior. ${ }^{15}$ Sumado a ello, los pagos por transferencia de tecnología y las ganancias remitidas al exterior bajo la política de "sustitución de importaciones" promovieron una industrialización dependiente del capital monopólico extranjero. Ello ocasionó que el déficit en cuenta corriente profundizara el desajuste en la balanza de pagos.

A causa de la regresiva distribución del ingreso, los desajustes sociales se hicieron evidentes. Hacia finales de la década de los sesenta el denominado "milagro mexicano" había llegado a su fin; los síntomas del resquebrajamiento social y político de la economía mexicana se tradujeron en demandas de una mayor democratización y mostraron cuán endeble era la política nacionalista que transfirió los problemas de la estructura económica convirtiéndolos en una compleja carga para nuestro pueblo. Como lo señala Fernando Carmona "...salta a la vista que uno de los pilares del celebérrimo desarrollo estabilizador fue el creciente endeudamiento del país". ${ }^{16} \mathrm{Tal}$ aseveración sería confirmada posteriormente por la misma historia de México.

${ }^{14}$ Manrique, Irma. La Política Monetaria en la Estrategia del Desarrollo. (Su impacto en América Latina y México). EDAMEx México, 1979.

${ }^{15}$ Martínez, Ifigenia. "La Distribución del ingreso en México. Tendencias y perspectivas", en El perfil de México en 1980, vol. I. Siglo XXI Editores, 1970. Bergsman, Joel. Income Distribution and Poverty in Mexico. World Bank Staff Working Paper, núm. 395, The World Bank, 1980. Cf. Cordera, Rolando. "Estado y desarrollo en el capitalismo tardío y subdesarrollado", en Investigación Económica. UNAM, vol XXXI, núm 123, 1971.

${ }^{16}$ Carmona, Fernando. El Milagro Mexicano. Ed. Nuestro Tiempo, México, 1970 , p. 72. 


\section{Del "desarrollo compartido" \\ a la "alianza para la producción"}

\section{El "Desarrollo compartido" de Luis Echeverría Álvarez}

Las primeras manifestaciones de la crisis en la sociedad mexiana plantearon la necesidad de crear una "nueva alternativa" para sacar avante al país cuando finalizaba la década de los sesenta. La alternativa fue Luis Echeverría Álvarez, quien ya en la presidencia y a los pocos días de su mandato señalaba:

Ante la realidad de una estructura fiscal poco flexible para sostener una política social más amplia, y ante la necesidad de "no continuar por la senda peligrosa del incremento en el endeudamiento externo", el nuevo gobierno de México ha empezado a adoptar "decisiones que se habían postergado", orientadas a "captar recursos internos adicionales para lograr el equilibrio presupuestal, la redistribución del ingreso entre la población y la mejor distribución de los ingresos tributarios entre municipios, estados y federación", con las cuales "se corrigen desviaciones tributarias que debilitaban el sistema fiscal mexicano y se amplía la base del impuesto, peligrosamente restringida en el pasado". ${ }^{17}$

Las reformas enunciadas por el Ejecutivo, se sintetizaron del modo siguiente:

a) Reforma de diversas disposiciones impositivas, tendientes a corregir desviaciones tributarias y tratos discriminatorios que debilitaban al sistema fiscal mexicano y ampliar la base impositiva.

b) Establecimiento de normas y criterios para la formulación, manejo y ejecución del presupuesto de egresos del sector público federal, previniendo una función presupuestal más estrechamente ligada a la realidad de la ejecución de los pro-

${ }^{17}$ Banco Nacional de Comercio Exterior, S. A. "México: la política económica del nuevo gobierno", en Comercio Exterior, vol. XX, núm. 12, México, diciembre de 1970 . 
gramas de gasto de las entidades del gobierno federal y de los organismos descentralizados sujetos a control presupuestal más estrechamente ligada a la realidad de la ejecución de los programas de gasto de las entidades del gobierno federal y de los organismos descentralizados sujetos a control presupuestal.

c) Expedición de un nuevo mecanismo de control por parte del gobierno federal, de los organismos y empresas del Estado, para llevar a cabo una vigilancia más acuciosa de la operación de estos organismos.

d) Fijación de una serie de bases para la promoción y coordinación de las reformas administrativas del sector público federal, para contribuir a la descentralización económica y al incremento de la productividad de la función pública. ${ }^{18}$

Las reformas a la Ley del Impuesto sobre la Renta en su base gravable tuvieron el objeto de obtener una mayor recaudación. En sí, la ley dio amplias facilidades a los empresarios en el fomento de la reinversión de utilidades, reestructuración del régimen de depreciación de activos fijos, igualación en el trato fiscal a los pagos por regalías y asistencia técnica, aplazamiento de la deducción de gastos en publicidad y generalización del impuesto sobre las ganancias de capital.

Con relación al impuesto sobre Ingresos Mercantiles, se creó una tasa adicional del $7 \%$ sobre el gasto en artículos de consumo no indispensables. Los Certificados de Devolución de Impuestos, utilizables únicamente para el pago de gravámenes federales, se crearon con el fin de reanimar las exportaciones de manufacturas que venían descendiendo por las políticas proteccionistas de los países desarrollados. La Ley de Ingresos y Presupuesto de Egresos de la Federación para 1971 fue modificada en función de lograr una mejor planeación administrativa, más apegada a un equilibrio presupuestal; los recursos del exterior, con prioridad, deberían ser

${ }^{18}$ Ibid. " Declaración del secretario de Hacienda y Crédito Público sobre la política económica del nuevo gobierno de México”, 18 de diciembre de 1970. 
usados en el "financiamiento de gasto de capital de rápida recuperación".

Desde un punto de vista "oficialista" el objetivo de la Reforma Fiscal fue contar con una estructura tributaria que gravara en forma rápidamente progresiva el ingreso personal, eliminando la discriminación en favor de los productores del capital y en contra de los ingresos derivados del trabajo, y en forma proporcional los ingresos de las empresas. La nueva estructura tributaria fue complementada con un impuesto también progresivo al gasto que gravaba las manifestaciones externas de la riqueza, por ejemplo el consumo suntuario.

En suma, a través del fortalecimiento de su estructura financiera, el sector público mexicano podría desempeñar adecuada y eficazmente el papel que le corresponde en la orientación del desarrollo nacional, de manera congruente con los objetivos generales de la estrategia económica que ha planteado la nueva administración mexicana. ${ }^{19}$

Las medidas adoptadas por el nuevo gobierno lograron sus objetivos. El segundo informe presidencial manifestaba que por primera vez se había reducido la deuda del sector público a plazo de un año o más; su incremento había sido de $2.5 \%$ en 1971, cifra muy inferior al promedio de los últimos años. Sin embargo, contrariamente a los resultados que debió haber arrojado una reforma tributaria (mayores ingresos y menor endeudamiento), el nivel general del gasto también se redujo, suponiendo su disminución un mecanismo para contener la inflación.

Posteriormente “...una vez reducidas las presiones inflacionarias (el incremento fue de $2.6 \%$ precios al mayoreo) y con el fin de reanimar la actividad económica, el gobierno federal aumentó considerablemente el gasto público y la inversión". ${ }^{20}$ Así, los niveles de la deuda externa a plazo mayor de un año llegaron a representar 3259.2 millones en 1970; 3554.4 millones en 1971 y 4322.2 millones de dólares en

${ }^{19}$ México a través de los Informes... p. 803.

${ }^{20}$ Op. cit. 
1972. Sin embargo, el déficit en cuenta corriente que llegaba a 945.9 millones en 1970 disminuyó 726.4 millones de dólares en 1971. Aun así, el desequilibrio externo se acentuó. Las medidas adoptadas por Estados Unidos el 16 de agosto de 1971 (el impuesto al 10\% de manufacturas provenientes de países como el nuestro) coadyuvaron al aumento del déficit en la cuenta corriente que en 1973 llegó a 1175.4 millones de dólares. ${ }^{21}$ La política adoptada para finales de 1972 y principios de 1973 fue resultado de la imposibilidad de administrar los efectos de la crisis económica. El Estado recurriría en forma desesperada al financiamiento externo.

La participación del Estado en la economía se incrementó. Los enormes gastos del gobierno federal pasaron de 77231 millones de pesos en 1972 a 238062 millones para 1976, es decir, crecieron en un $32.54 \% .{ }^{22}$ Esto puso en evidencia la ampliación y el fortalecimiento del aparato burocrático, que ya no sería característico sólo del régimen echeverrista sino una tendencia para años posteriores.

Los ingresos del Estado, por su parte, aumentaron un 20\% al pasar de 76589 millones de pesos en 1972 a 286649 millones de pesos en 1976. La mayor porción provino de ingresos corrientes, los cuales aumentaron un $33 \% .^{23} \mathrm{En}$ el periodo 1972-1976, aumentaron $32 \%$ los ingresos corrientes por concepto de impuestos sobre la renta y los ingresos mercantiles crecieron $18 \%$, mostrando el carácter de un régimen fiscal y tributario fuertemente regresivo y favorecedor al capital.

No obstante, el régimen echeverrista enfatizó su política tutelar a través de un incremento en la infraestructura en educación, la ampliación de los planes de vivienda y de empleo

${ }^{21}$ Las reservas del Banco de México aumentaron de 102.1 millones en 1970 a 200.0 millones en 1971 y 264.7 millones de dólares en 1972; dicho año sería el punto culminante de mayor crecimiento en el sexenio pues éstas tenderían a disminuir en los años siguientes hasta llegar a ser negativas en 320.9 millones de dólares en 1976.

${ }^{22}$ En su mayor parte correspondió a gastos corrientes, a los gastos de capital únicamente les correspondió 25374 a 72013 millones en el mismo periodo.

${ }^{23}$ Banco de México. Informe Anual, 1976. 
y los aumentos de salarios. En materia jurídica se establecieron varias leyes: la Ley para Promover la Inversión Mexicana y Regular la Inversión Extranjera, la Ley de Registro de Transferencia de Tecnología y sobre el Uso de Explotación de Patentes y Marcas, la Ley Federal de Protección al Consumidor, la Ley General de Instituciones de Crédito. ${ }^{24}$

La administración de Luis Echeverría puso fin a la política de "estabilización" al devaluar el tipo de cambio cuya paridad de 12.50 pesos por un dólar se mantuvo durante 22 años.

Luis Echeverría Álvarez diría el 1 de septiembre de 1976:

Es justificado obtener financiamiento externo para apoyar el aparato productivo nacional y mejorar nuestra eficiencia; es menos justificable obtener créditos externos para financiar en forma permanente deficiencias de bienes de consumo o de materias primas; pero resulta absolutamente inaceptable permitir aumentos excesivos de la deuda pública externa o utilizar las reservas básicas de oro y divisas del Banco de México para financiar salidas especulativas de capital exterior. ${ }^{25}$

La flotación del peso mexicano de aproximadamente $100 \%$ frente al dólar hizo necesario el establecimiento de un plan de emergencia, acompañado de una estrategia económica y financiera:

- Recuperar y preservar la capacidad competitiva de nuestras exportaciones de bienes y servicios. Para ello, deberá asegurarse que la elevación de los precios y costos internos sea sustancialmente menor que el ajuste en el tipo de cambio.

- Proteger el poder adquisitivo de las clases populares.

${ }^{24}$ Con la intromisión de la Banca Múltiple se favorece la constitución de grupos financieros y se alienta la "descentralización" de las actividades bancarias en beneficio de nuevas inversiones y estímulos; para los pequeños ahorradores el objeto fue incentivar la captación financiera en un momento de fuerte recesión. Al respecto véase: Cardero, María Elena. Patrón Monetario y Acumulación en México. (Nacionalización y control de cambios). Instituto de Investigaciones Sociales, UNAM. Siglo XXI Editores, México, primera edición, 1984. También: Quijano, José Manuel. México, Estado y Banca Privada. CIDE, primera edición, México, 1981.

${ }^{25}$ Echeverría Álvarez, Luis. Informe de Gobierno. 1 de septiembre de 1976. 
- Evitar lucros indebidos.

- Proteger la salud financiera de las empresas.

- Controlar el déficit público.

- Regular el crecimiento del crédito.

La necesidad de aplicar un plan de estabilización de características convenidas entre las autoridades monetarias y las del FMI, venía argumentándose desde la visita de tres misiones del Fondo. La primera en octubre-noviembre de 1974, luego en febrero de 1975 y otra en febrero-marzo de 1976. En agosto de ese año se llevó a cabo una visita oficial mexicana a Washington precedida por el director del Banco de México. En agosto-septiembre las autoridades mexicanas se sumaron al programa del Fondo.

El apoyo financiero consistió en 1975 millones de dólares; 212.8 millones girados sobre el tramo de financiamiento compensatorio por bajas en las exportaciones y para corregir un desequilibrio en la balanza de pagos; 154.2 millones con cargo al tramo oro; 595.7 millones con un crédito contingente (como seguro y garantía para la obtención de créditos) que podría ser girado en un periodo de tres años. En el mes de noviembre se recibió, además, un préstamo "sindicalizado" en el mercado de eurodólares por 800 millones de dólares, proveniente de grandes bancos trasnacionales. ${ }^{26}$

El país quedó comprometido con el exterior dos meses antes que el presidente entregara el poder con un nivel de endeudamiento de cerca de 20 mil millones de dólares; los intereses de la deuda tuvieron un crecimiento de $74.9 \%$ debido al mayor endeudamiento de los últimos años del sexenio. Por otra parte, la situación interna se agravó a causa del incremento de los precios y la incertidumbre que generó la flotación del peso.

${ }^{26}$ Cf. Document of International Monetary Fund and not for Public use. EBS 76-424; 23 de septiembre de 1976; véase también: Colmenares, David R. "La economía mexicana y el FMI", en El Economista Mexicano, vol. XII, núm. 6, noviembre-diciembre de 1978. Torres Gaitán, Ricardo. Un siglo de devaluaciones del peso mexicano. Siglo XXI Editores, 1980, p. 353. 
La "Alianza para la producción" de José López Portillo

La crisis económica se prolongó en el nuevo periodo sexenal, iniciado el 1 de diciembre de 1976. El nuevo presidente había estado al frente de la Secretaría de Hacienda y Crédito Público, distinguiéndose como experto en finanzas internacionales y conocedor de la situación económica del país. En los foros internacionales se había pronunciado a favor del financiamiento externo y la necesidad de crear mecanismos que permitieran la permanente transferencia real de recursos hacia los países en desarrollo. Expresaría así una voluntad de coordinación ligada a los aspectos técnicos sugeridos por el FMI.

Las medidas de política económica a las cuales la nueva administración tendría que acoplarse serían: 1 . estrecha vigilancia del FMI durante los tres primeros años de su administración (del 1 de enero de 1977 al 31 de diciembre de 1979). 2. reducción del gasto público. 3. incremento del empleo en el sector público en no más de $2 \%$ en 1977 . 4. crecimiento de salarios en $10 \%$. 5. en materia crediticia, el tope del financiamiento no sobrepasaría los 3 mil millones de dólares, y 6 . liberación de los precios de bienes-salario.

Con el llamado a una Alianza para la producción, se puso en marcha una reforma administrativa, que incluyó la Ley de Deuda Pública, que entró en vigor el 1 de enero de $1977 .{ }^{27}$ El presidente en su Primer Informe de Gobierno dijo:

Hace 39 semanas iniciamos una nueva etapa en la vida administrativa y política de nuestro país. La economía atravesaba entonces por el momento más crítico que le ha tocado vivir a la presente generación. Apenas 12 días antes - el 19 de noviembre- se había manifestado en forma dramática, sin precedentes, en las oficinas bancarias de toda la República, el trance de desconfianza en las instituciones, en las autoridades, en la nación, en nosotros mismos. Los precios subían en un mes, lo que en otro tiempo aumentaban en un año. La deuda pública se había elevado a casi cinco veces en un sexenio, el

${ }^{27}$ Nacional Financiera. "Iniciativa de Ley de Deuda Pública". en El Mercado de Valores. Año XXXVI, núm. 52, 27 de diciembre de 1976. 
desempleo se multiplicaba. La balanza comercial desproporcionada, había alcanzado un déficit cercano a los mil millones de dólares en 1975 y se iba a aproximar a los tres mil en el año que estaba por concluir. El incremento de la producción había caído a $2 \%$; inferior al índice de crecimiento de la población. México estaba, en síntesis, en el punto más difícil, de mayor escepticismo, más oscuro de la encrucijada. Así recibimos, hace apenas unos meses a la nación. ${ }^{28}$

$\mathrm{Y}$, concretando en torno a la situación financiera, informó al Honorable Congreso de la Unión sobre la deuda externa total: "Al 30 de junio ascendía a 20948 millones de dólares. Conforme a los propósitos del programa de gobierno, el aumento neto del endeudamiento externo en 1977 será bastante menos de la mitad del obtenido en 1976, mejorándose también su estructura de plazos"'. ${ }^{29}$

Dentro de los objetivos primordiales planteados por la administración de López Portillo se señaló en discursos oficiales, en los términos de la Ley de Deuda Pública pero bajo las directrices del FMI, mejorar el perfil de la deuda externa. ${ }^{30}$

${ }^{28}$ Cf. López Portillo, José. Primer Informe de Gobierno, Secretaría de Programación y Presupuesto, 1977.

${ }^{29}$ Ibid.

${ }^{30} \mathrm{Cf}$. las siguientes citas que proceden de los Informes Presidenciales:

" Al 30 de junio pasado su saldo total era del orden de 25 mil millones de dólares de los cuales 22 mil estaban contratados a plazos de un año o más y los restantes a menos de un año. A la misma fecha la deuda interna del gobierno federal llegó a 320 mil millones de pesos. Hemos cumplido con la Ley General de Deuda Pública estimulando el ahorro gubernamental y saneado la estructura financiera de las empresas paraestatales de los cuales en este periodo se fusionaron 12 y se liquidaron 70". López Portillo, José. Segundo Informe de Gobierno. Secretaría de Programación y Presupuesto, 1978.

"El saldo de la deuda externa del sector público al próximo pasado 30 de junio era de 27939 millones de dólares. En términos relativos se estima que este año una tasa de crecimiento cercana al $13 \%$ y su coeficiente de relación con el PIB disminuirá en este año hasta un $26 \%$. Se avanza en mejorar la estructura de la deuda pública y en abatir su costo. Se ha logrado reducir drásticamente la de corto plazo". López Portillo, José. Tercer Informe de Gobiemo. Secretaría de Programación y Presupuesto, 1979.

"El saldo de la deuda externa al 30 de junio alcanzó la cantidad de 32 mil millones de dólares. La posición de la balanza de pagos y los resultados en el endeudamiento externo han permitido fortalecer la reserva bruta internacional del Banco de México que al 31 de agosto llegó a 6268.3 millones de dólares correspondiéndole a la reserva primaria 3603 millones y a la secundaria 2665.3 millones de 
La coyuntura internacional y la profundización de la explotación petrolera permitieron que durante los tres primeros años de gobierno el nivel de endeudamiento se mantuviera en 3 mil millones de dólares anuales y se mejorara su perfil. El coeficiente del PIB con respecto a la deuda externa descendió de $28.5 \%$ en 1976 a $22.1 \%$ en $1979 .{ }^{31}$ La relación del servicio de la deuda externa respecto a las exportaciones de bienes y servicio (coeficiente del servicio de la deuda), disminuyó al pasar de $63 \%$ en 1979 a $30 \%$ en $1980 .^{32}$

Los préstamos contratados durante 1980 superaron el límite de endeudamiento. En el marco de la segunda etapa bianual del Plan Global de Desarrollo del país, una vez recuperada la crisis económica, pasó a tasas de crecimiento superiores a cualquier país desarrollado, de 7 y $8 \%$ en 1979 y 1980, respectivamente. La estrategia de este desarrollo se basó en el boom petrolero, siendo el endeudamiento el pilar de dicho "crecimiento" al canalizar en $42 \%$ los recursos del sector energético al petróleo, según datos de Nacional Financiera.

\section{De la "Crisis de liquidez" al "Desfinanciamiento del pais"}

En efecto, la tercera etapa de la política de endeudamiento externo empieza cuando el entorno internacional desfavorece el boom petrolero y las tasas de interés en el mercado financiero internacional crecen a niveles históricos.

dólares"'. López Portillo, José. Cuarto Informe de Gobiemo. Secretaría de Programación y Presupuesto, 1980.

" El monto de la deuda pública externa ascendió al final de 1980 a 34 mil millones de dólares; para 1981 el saldo tendrá que revisarse una vez que se precise el de las exportaciones de petróleo y la evolución de las importaciones. Sin embargo se ha reducido sustancialmente a cerca de la mitad de lo que era en 1977'". López Portillo, José. Quinto Informe de Gobierno. Secretaría de Programación y Presupuesto, 1981.

31 Véase: "Producto Interno Bruto" y "Deuda Externa Total" en el Apéndice Estadístico de los Informes de Gobierno. Secretaría de la Presidencia, varios años, México D. F.

${ }^{32}$ Ibid. 
El presidente López Portillo reseñaba en el Sexto Informe de Gobierno:

...en el caso de México el pago por intereses de la deuda pública y privada, documentada, alcanzaba en 1978 a 2606 millones de dólares mientras que en 1981 correspondía a 8200 millones. De este modo, los pagos por intereses registraron un crecimiento prácticamente exponencial y se convirtieron en el principal elemento de presión contra la cuenta corriente de la balanza de pagos. La estructura del endeudamiento externo, en la que ganaron importancia los financiamientos a corto plazo, favoreció también el incremento de la carga por servicio derivado de los mayores intereses. Los plazos cortos nos obligan a inconvenientes negociaciones frecuentes y riesgosas. ${ }^{33}$

A ello se agrega la fuga de capitales y el desmedido ambiente de especulación propiciado por los banqueros, así como la creciente desconfianza que provocó la devaluación de febrero de ese año y la agudización de los fenómenos monetarios en agosto de 1982, la nacionalización de la banca y el control de cambios del nuevo sexenio y la adopción de una política diferente a los años anteriores, pero de mutuo acuerdo con el FMI.

El Plan Nacional de Desarrollo puesto en práctica por el nuevo sexenio definirá claramente la política de endeudamiento externo: este

girará, en el corto plazo, alrededor de su reestructuración y rehabilitación. En este horizonte, un endeudamiento adicional y marginal puede contribuir de manera significativa a distribuir mejor en el tiempo el ajuste económico necesario y aliviar los costos sociales correspondientes. La estrategia financiera de mediano plazo requiere seguir utilizando el crédito externo - de manera decreciente- para complementar el financiamiento del desarrollo. ${ }^{34}$

${ }^{33}$ Nacional Financiera. "Sexto Informe de Gobierno del Presidente José López Portillo", en El Mercado de Valores. Año XLII, núm. 36, septiembre de 1982.

${ }^{34}$ Nacional Financiera. El Mercado de Valores, año XLVII, suplemento núm. 24, 31 de junio de 1983. 
Las renegociaciones sucesivas se fueron adaptando a las necesidades del país sin inmiscuirse en movimientos internacionales de confrontación; proceso acompañado de los acuerdos de estabilización firmados con el FMI. El sexenio concluiría con el éxito monetarista deseado de haber logrado el desendeudamiento del país. ${ }^{35}$

\section{El marco internacional del cambio sexenal}

Para brindar un marco comprensivo de la situación en que se desenvolvía la economía mexicana hacia fines de 1982, haremos algunas referencias a la crisis del sistema en que el país está inmerso y sus efectos sobre esa coyuntura nacional.

$\mathrm{El}$ asunto nos lleva, ineludiblemente, a hablar de las transformaciones que está sufriendo el capitalismo, particularmente en Estados Unidos, y la fuerte participación de este proceso en la crisis mexicana. Un nuevo modelo de acumulación, con mayor grado de desarrollo de las fuerzas productivas, se traslada a través de las fronteras y México resiente la transformación necesaria del capitalismo para detener la tendencia descendente de la tasa de ganancia que se había observado años anteriores.

La ola de fondo que rige este movimiento está, indudablemente, en la economía mundial: el fin de la larga fase expansiva posterior a la segunda guerra mundial, la nueva revolución tecnológica de la era microelectrónica, la reestructuración del capitalismo y del mercado mundial, la recomposición de las relaciones entre las clases y entre las naciones. En la economía, en la política y en la sociedad y su cultura, a este panorama se le nombra con una palabra: crisis [...] México, frontera de los pobres del mundo con Estados Unidos, el más rico y poderoso entre los ricos, vive esta crisis con una intensidad particular. El capital y el Estado, dueños de la iniciativa en la primera mitad de esta década están tratando de organizar su salida de la crisis a través de una reestructuración económica, una nueva inserción en el mercado mundial y, en consecuencia, un nuevo modelo de dominación. ${ }^{36}$

${ }^{35}$ De la Madrid Hurtado, Miguel. Quinto Informe de Gobierno, 1987.

${ }^{36}$ Gilly, Adolfo. "La modernización del capitalismo mexicano", en Nexos, núm. 97, enero de 1986, p. 45. 
En el idioma de los organismos internacionales, el Banco Interamericano de Desarrollo (BID) interpreta así este proceso:

Pero no es el crecimiento del volumen de la deuda lo que por sí origina problemas de pagos externos. Más bien es el deterioro de su estructura y de sus términos de interés y plazos de vencimiento lo que, en determinadas circunstancias, puede derivar en una carga excesiva sobre la economía de los países deudores. ${ }^{37}$

Es decir, en la visión que caracteriza al organismo, se niega importancia decisiva al volumen de la deuda externa, poniendo el acento sobre el perfil del endeudamiento para explicar la crisis, lo que la relaciona con la naturaleza de las políticas económicas internas y la evolución de las condiciones económicas y financieras internacionales. Vale decir, no cuestiona el endeudamiento y su crisis sino como parte, como variable, dentro de los numerosos factores que concurren a la conformación de un sistema capitalista que integra a los países subdesarrollados.

Sin embargo, este proceso aparece en medio de una etapa crítica para la economía mundial. Desde mediados de 1979 la mayor parte de los países de la Organización para la Cooperación y el Desarrollo Económico (OCDE), que agrupa a las potencias industriales de occidente, se vieron enfrentados al reto de reducir la inflación. Como ninguno de ellos (y mucho menos el país líder del grupo, Estados Unidos) mostraba disposición a restringir el déficit fiscal como medida de corrección del factor inflacionario, la carga de este proceso recayó sobre la actividad económica que, en general, sufrió un descenso bastante pronunciado. Así, aunque el mundo desarrollado obtuvo éxitos en el control de la inflación, lo hizo a costa de un desaceleramiento en el ritmo de crecimiento que, después de promediar $4.1 \%$ anual en el periodo 1976-

${ }^{37}$ Banco Interamericano de Desarrollo. La deuda externa y el desarrollo económico de América Latina. Washington, D.C., enero de 1984, p. 1. Véase: Ortiz Mena, Antonio. América Latina en desarrollo. Una visión desde el BID (Exposiciones y Documentos 1981-1985), Washington, D. C., enero de 1986. 
1979 cayó a sólo $1.2 \%$ en 1980 y a $-0.3 \%$ en $1982 .{ }^{38} \mathrm{Sin}$ embargo, según la OCDE, un tercio o más de la reducción de la inflación en los países industriales fue posible gracias a la caída de los precios que en ese periodo sufrieron las materias primas que importaban. Este deterioro se originó en la disminución de la demanda que acompañó la recesión del mundo industrializado.

"La recesión en los países industriales, que ha frenado la demanda por las exportaciones de los países en desarrollo no petroleros, ha contribuido a empeorar los términos de intercambio de estos últimos en $20 \%$ entre 1978 y 1982 ', afirma el Banco de México en la obra citada, y agrega: "Cabe señalar que los términos de intercambio de los países en desarrollo de ingresos bajos, cuyas exportaciones son básicamente materias primas, se deterioraron durante esos cinco años en 38.4 por ciento". ${ }^{39}$

Si se agrega a estos factores el hecho de que en el mismo periodo las tasas de interés sufrieron alzas que incrementaron espectacularmente las cifras del costo del servicio de la deuda externa del mundo subdesarrollado, se completa el panorama por el que atraviesa la economía mexicana en proceso de reestructuración. A partir de 1982 hay que añadir, además, la reducción en los precios del petróleo, principal producto de exportación del país.

El Banco de México afirma:

La balanza de pagos de los países en desarrollo no-petroleros (México se halla inscrito en este grupo) ha sido afectado por las altas tasas de interés en los mercados financieros internacionales, la debilidad económica de los países industriales, la intensificación del proteccionismo y la disminución de los precios internacionales de los productos primarios. ${ }^{40}$

\footnotetext{
38 Banco de México. Informe Anual, 1982, p. 5.

39 Ibid., p. 16.

40 Loc. cit.
} 


\section{Antecedentes de la “Crisis de liquidez"}

\section{La deuda de corto plazo}

De 1980 y hasta 1982 , la deuda externa de corto plazo tuvo incrementos desmesurados. A pesar de la baja de los precios en el mercado petrolero, el gobierno insistía en mantener el control social al mismo tiempo que los privilegios de las clases altas: en la coyuntura recurría al endeudamiento, construyendo un perfil financiero del país que conduciría luego a la crisis.

Como fuente para el análisis se utilizó la información vertida en un documento ${ }^{41}$ que refleja el estudio que hace el gobierno mexicano, sobre la evolución económica del país para presentar ante el FMI.

Un análisis del cuadro 1 permite comprobar que en 1979 la deuda externa mexicana total alcanzaba 40389 millones de dólares. Para 1982 esta cifra se había incrementado, ascendiendo hasta 87875 millones de dólares, es decir, algo más del doble. La deuda del sector público creció de $29889 \mathrm{mi}-$ llones de dólares en 1979 a 62064 hacia finales de 1982, lo que equivale también a una duplicación de los adeudos, con lo que seguiría la misma tendencia que la deuda total. Sin embargo, la deuda del sector privado, en el mismo lapso, sufre un crecimiento de una vez y media: de 7900 millones de dólares a 18 mil millones, lo que expresa una tasa relativa de crecimiento mayor que la deuda pública y las cifras globales.

El cuadro muestra otra significativa característica: la deuda de mediano y largo plazos no alcanza a duplicarse, mientras la de corto plazo se eleva cuatro veces. La primera, crece de 28447 millones de dólares en 1979 a 49172 millones de dólares en 1982.

Veamos, en relación a la deuda de corto plazo, la del sector público: pasa de 1442 millones de dólares en 1979 a 9335 a fin de 1982, con una tasa de crecimiento relativo de casi ${ }^{41}$ Obsérvese el cuadro 1 que corresponde al cuadro 45 del Apéndice del " $\mathrm{Cu}$ rrent Economic and Prospect of México"'. FMI (mimeo), 1984. 


\section{CUADRO 1}

\section{DEUDA EXTERNA PENDIENTE, POR MADUREZ \\ Y TIPO DE PRESTAMISTA \\ (Millones de dólares)}

\begin{tabular}{|c|c|c|c|c|c|}
\hline & 1979 & 1980 & 1981 & 1982 & 1983 \\
\hline Deuda Total & 40389 & 51388 & 75061 & 87875 & 88852 \\
\hline A mediano y largo plazo & 33947 & 39622 & 52407 & 59234 & 63406 \\
\hline A corto plazo ${ }^{6}$ & 6442 & 11766 & 22654 & 28641 & 25446 \\
\hline Sector Público ${ }^{I}$ & 29889 & 34448 & 53161 & 62064 & 62947 \\
\hline A mediano y largo plazo & 28447 & 32322 & 42207 & 49172 & 53259 \\
\hline Instituc & (21 385) & $(24744)$ & $(31798)$ & $(36843)$ & $(38845)$ \\
\hline Bonos & $(2824)$ & ( 2807$)$ & ( 3 & ( 5 456) & $(4885)$ \\
\hline \multicolumn{6}{|l|}{ Organizaciones } \\
\hline Internacionales & $(2826)$ & ( 3286$)$ & $(4016)$ & ( & (00) \\
\hline MI & 132) & - -) & $-)$ & 675) & 954) \\
\hline ilatera & 834) & $\left(\begin{array}{ll}1 & 189\end{array}\right)$ & $(2270)$ & ( 2865$)$ & $4056)$ \\
\hline tros & 446) & 296) & 289) & 261) & 153) \\
\hline Deud & 1442 & 1491 & 10754 & 9335 & $9688^{4}$ \\
\hline Pemex & -- & 675 & 200 & 1604 & - \\
\hline cional de & -- & -- & -- & 1953 & - \\
\hline Bancos & 2600 & 510 & 7000 & 7811 & 7905 \\
\hline m & & & 1900 & 553 & 647 \\
\hline $\mathrm{cos}$ & 1900 & 3800 & 5100 & 7258 & 7258 \\
\hline ctor $P$ & 7900 & 11800 & 14900 & 18000 & 18000 \\
\hline me & 4800 & 6000 & 8300 & 9500 & 9500 \\
\hline co & 3100 & 5800 & 6600 & 8500 & 8500 \\
\hline Deuda a & 33327 & 43135 & 64452 & 71 & 74438 \\
\hline 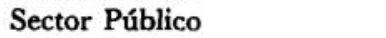 & 22827 & 26235 & 42552 & 45 & 4853 \\
\hline \multicolumn{6}{|l|}{ Sector privado y bancos } \\
\hline racionalizados & 10500 & 16900 & 21900 & 25 & 25905 \\
\hline
\end{tabular}

Incluye créditos externos del Banco de México con el FMI, BIS, Departamento del Tesoro de Estados Unidos y de la Reserva Federal pero nofincluye acuerdos de pagos bilaterales o carta de crédito.

2 Incluye deuda del C.C.C.

3 Pertenece en su mayoría a préstamos de bancos comerciales. Excluye cartas de crédito.

Incluye deuda en proceso de ser restructurada a periodos más largos de madurez. No incluye créditos relacionados con el comercio.

Incluye contratos de Pemex y deuda con el BIS y operaciones con el Departamento del Tesoro y la Reserva Federal.

Incluye toda la deuda de diferentes periodos de madurez.

Fuente: FMI. Current Economic and Prospects of México 1984. Datos provenientes de las autoridades mexicanas de la Secretaría de Hacienda y Crédito Público; estimaciones propias del equipo del Fondo. 
siete veces, en tanto este mismo rubro, pero para el sector privado, va de 3100 millones de dólares a 8500 , es decir, no alcanza a triplicarse.

En los préstamos contratados a corto plazo, la deuda del sector público creció en el periodo a una tasa superior en dos veces a la del sector privado. Pero, es preciso señalarlo, la serie muestra que el sector público presentaba una deuda de 1442 millones de dólares en 1979, y que ésta se elevó abruptamente a 10754 únicamente en el año 1981, para luego estabilizarse en el resto del periodo en cifras de rango similar.

Cabe también destacar que la deuda asumida por los allí denominados "Bancos Nacionales" (dato que en general no aparece en otras fuentes informativas), también se elevan tres veces, pero especialmente por efecto de las contrataciones de corto plazo: mientras el total de la deuda de los bancos nacionales se eleva de 2600 a 7811 millones de dólares -vale decir tres veces-, la de término corto pasa de 1900 a 7258 millones de dólares - lo que equivale a casi el cuádruple.

Llama también la atención el proceso de la deuda, tanto de corto como de mediano plazos, con la banca mundial. Estos adeudos, en general, se elevan un par de veces, pero la del sector público muestra diferentes comportamientos antes de la nacionalización de la banca. Si, en su totalidad, los adeudos bancarios crecen de.33 327 en 1979 a 71 mil en 1982, el gran salto se opera entre 1981 y 1982. De ellos son principalmente responsables los créditos contraídos por el sector privado y la banca nacionalizada, que si entre 1979 y 1981 sólo se elevaron en algo más de seis mil millones de dólares (de 10500 a 16 900), durante este último año y 1982 crece abruptamente hasta superar los 25 mil millones de dólares.

Otro aspecto que vale la pena mencionar al observar las cifras del mismo cuadro, es el rubro Instituciones Financieras en la constitución de la deuda del sector público. Ésta, en el periodo en que el total del endeudamiento se duplica, crece de los 21385 millones de dólares hasta los 38 843, con un gran incremento concentrado también en los años 1980 y 1981 (cuando sube de 24744 a 31798 millones de dólares). 
Las primeras conclusiones de esta lectura permiten afirmar que la deuda de México en el periodo que va de 1979 a septiembre de 1983, mantuvo un incremento continuo pero no gradual, ya que son los empréstitos contratados en el periodo 1981-1982 los que terminan por configurar el gran crecimiento registrado. Mientras la tasa general de incremento en todo el periodo fue de aproximadamente el $220 \%$, la registrada sólo entre los años 1981 y 1982 llega a $217 \%$. Asimismo, se puede ver que es la deuda de corto plazo la que contribuye de manera privilegiada al crecimiento del endeudamiento general. En términos relativos, la deuda de corto plazo se incrementa en todo el periodo en un $410 \%$, en tanto la de mediano y largo términos lo hace a razón de una tasa inferior al $200 \%$. Sin embargo, en este rubro el crecimiento registrado entre 1979 y 1982 llega a $174 \%$, mientras que el endeudamiento a corto plazo en el mismo periodo supera el 440 por ciento.

\section{La fuga de capitales}

El acelerado endeudamiento en que incurrieron los grupos bancarios privados mexicanos en el plazo indicado en este cuadro, muestra una diferente cara de la crisis: la fuga de capitales. Las deudas de este sector pasan de los 2600 a los 7905 millones de dólares entre 1979 y septiembre de 1983, creciendo a una tasa levemente superior al 300 por ciento.

Silva Herzog, entonces subsecretario de Hacienda, reconoció en abril de 1981 que "el éxodo de capitales al extranjero, tanto de las corporaciones trasnacionales como de las empresas nacionales, se puede calificar de muy activo". La fuga de capitales se atribuía al pago del servicio de la deuda, a las utilidades giradas al exterior por la inversión extranjera, a las erogaciones por usos de tecnología importada. Pero las cifras mencionadas empiezan a denunciar un fenómeno menos nuevo: las inversiones mexicanas realizadas por empresas y particulares en el extranjero. ${ }^{42}$

${ }^{42}$ Véase cuadro 1 y cuadro 2. 


\section{CUADRO 2}

\section{CAPITALES MEXICANOS}

\section{FINANCIAMIENTO NETO Y FUGA DE CAPITALES \\ (Millones de dólares)}

\begin{tabular}{|c|c|c|c|c|c|}
\hline Años & $\begin{array}{r}\text { Financia- } \\
\text { miento } \\
\text { externo } \quad \text { neto }{ }^{I} \\
\\
(A)\end{array}$ & $\begin{array}{r}\text { Errores } \\
y \\
\text { Omisiones } \\
(B)\end{array}$ & $\begin{array}{r}\text { Activos } \\
\text { netos del } \\
\text { exterior } \\
(C)\end{array}$ & $\begin{array}{r}\text { Fuga } \\
\text { de } \\
\text { capitales } \\
(D=B+C)\end{array}$ & $D / A$ \\
\hline 73 & 2336.0 & -400.2 & -450.2 & 850.4 & 36.4 \\
\hline 74 & 4060.0 & $-\quad 559.6$ & -480.4 & -1040.0 & 25.6 \\
\hline 1975 & 5483.3 & -851.2 & $-\quad 195.4$ & -1046.0 & 19.1 \\
\hline 1976 & 5724.3 & -2390.6 & -753.6 & -3144.2 & 54.9 \\
\hline 1977 & 2973.5 & 22.5 & - 927.6 & 950.1 & 31.9 \\
\hline 1978 & 3378.8 & -127.0 & -474.8 & 601.8 & 17.8 \\
\hline 1979 & 5592.7 & -686.2 & -1768.7 & -2454.9 & 43.9 \\
\hline 1980 & 11690.2 & $-3,647.6$ & - 865.2 & -4512.8 & 38.6 \\
\hline 1981 & 23572.7 & -8372.7 & -2532.1 & -10904.8 & 46.3 \\
\hline 1982 & 9154.2 & -5270.8 & -2517.6 & -7788.4 & 85.1 \\
\hline 1983 & 2328.1 & -1917.1 & -3324.1 & -4241.2 & 182.2 \\
\hline 1984 & $123.9^{2}$ & -1150.7 & -2366.8 & -2517.5 & $2032.0^{3}$ \\
\hline $1985^{4}$ & 247.0 & -482.0 & -340.0 & 822.0 & 332.7 \\
\hline
\end{tabular}

1 Saldo de los siguientes renglones de la balanza de pagos: disposiciones de créditos y colocación de bonos del sector público, menos amortizaciones de créditos y bonos del sector público, más pasivos netos con el exterior del sector privado, más pasivos de corto plazo, públicos y privados.

2 El saldo negativo es consecuencia de la severa restricción de créditos externos, que coadyuva a que México se constituya en exportador neto de capitales a partir de 1983.

3 El elevado porcentaje refleja, por un lado, la contracción del financiamiento externo neto y, por otra, la permanencia de un importante monto de divisas fugadas.

4 Datos elaborados con base en los Informes de Comercio Exterior del Banco de México, referentes al primer trimestre de ese año.

Fuente: Indicadores Económicos, Informes de Comercio Exterior del Banco de México. Excélsior, 15 de enero de 1986. 
En 1980, Banamex adquirió dos bancos en California, Bancomer compró otro en San Diego y varias empresas pertenecientes a esos grupos financieros transfirieron en los primeros años de la década de los ochenta una gruesa suma de dólares, con el resultado que se observa en el cuadro. ${ }^{43}$ Estas misma cifras denuncian, a la vez, otro fenómeno. A partir de la devaluación de febrero de 1982 y del llamado "deslizamiento" implantado por la conducción económica mexicana, perdió credibilidad el valor del peso, y los altos intereses pagados fuera de las fronteras alentaron la inversión especulativa en el exterior, incrementando la fuga de divisas. ${ }^{44}$

\section{El desorbitado endeudamiento de Pemex}

Entre 1980 y 1982, al tiempo que la deuda de corto plazo crecía sorpresivamente, entre sus componentes se destacaban los préstamos contratados para la empresa petrolera estatal.

Del Sexto Informe de Gobierno del presidente López Portillo, ${ }^{45}$ surgen datos irrefutables al respecto. En general, la información del cuadro confirma lo dicho hasta ahora: en 1980 la deuda contraída por el sector público ascendía a $1491 \mathrm{mi}$ llones de dólares. Pero un ejercicio después, los adeudos a menos de un año del mismo sector se habían elevado a 10754 millones de dólares (cuadro 3).

En general, las deudas de las instituciones registradas en el cuadro tienen un crecimiento bastante significativo, todas con un pico sobresaliente en el año de 1981. Nacional Financiera aparece en 1980 con la cifra de 150 millones de dóla-

${ }^{43}$ De Munguía, Valdemar. "'Fuga de capitales y crisis económica: los capitales exiliados mexicanos después de la devaluación en una comunidad de California", en Investigación Económica, núm. 181, julio-septiembre de 1987, pp 207-234. Véase cuadro 2 de este capítulo.

44 “"El 18 de febrero se inició un periodo de flotación de tipo de cambio. Hacia fines del mes éste alcanzó niveles cercanos a 45 pesos por dólar, lo cual significó una depreciación de aproximadamente $67 \%$ ". Cf. Banco de México. Informe Anual, 1982, p. 37.

${ }^{45}$ López Portillo, José. Informe Presidencial, Anexo Estadístico I, p. 299. Véase cuadro 3 y otros Informes Presidenciales. 


\section{CUADRO 3}

SALDOS DE LA DEUDA EXTERNA DEL SECTOR PÚBLICO A PLAZO MENOR DE UN AÑO, POR DEUDOR ANTE EL EXTRANJERO

(Millones de dólares)

\begin{tabular}{|c|c|c|c|c|c|c|c|c|c|}
\hline & & 1980 & 1981 & 1982 & 1983 & 1984 & $1985^{\circ}$ & 1986 & 1987 \\
\hline TOTAL & & 1491 & 10754 & 9325 & 9777 & 384 & 454 & 1894 & 561 \\
\hline Nacional Financiera & & 150 & 2002 & 1687 & 1698 & - & 17 & 5 & 4 \\
\hline Banobras & & 79 & 727 & 790 & 898 & - & - & - & - \\
\hline Pemex & & 157 & 4063 & 3159 & 2964 & - & - & 67 & 100 \\
\hline Sociedad Mexicana de Crédito & & & & & & & & & \\
\hline Industrial & & 441 & 473 & & & & & & \\
\hline Banext & & 295 & 1312 & 1143 & 1103 & 203 & 237 & 275 & 214 \\
\hline Banco Nacional Agropecuario ${ }^{1}$ & & & & & & & & & \\
\hline Banco Nacional de Crédito Rural ${ }^{2}$ & 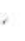 & 45 & 790 & 588 & 671 & - & - & - & 一 \\
\hline Financiera Nacional Azucarera ${ }^{3}$ & & & 60 & 164 & 442 & - & - & - & - \\
\hline Otros $^{4}$ & & 324 & 1327 & 1794 & 2001 & 181 & 200 & 1547 & 243 \\
\hline
\end{tabular}

${ }^{1}$ A partir de 1975 los Bancos de Crédito Agricola Ejidal y Agropecuario se fusionan con el Banco Nacional de Crédito Rural.

${ }^{2}$ Incluye cifras de: Banco Nacional de Crédito Agrícola y Banco Nacional de Crédito Ejidal.

${ }^{3}$ A partir de 1973 la deuda exterior de Financiera Nacional Azucarera se incorporó en el total.

${ }^{4}$ Entre los principales destacan Fertimex, Conasupo y AHMSA.

P Cifras preliminares.

fuente: Secretaría de Hacienda y Crédito Público. Dirección General de Crédito Público, Banco de México; Miguel de la Madrid Hurtado Sexto Informe de Gobierno 1988. Anexo Estadístico, pp. 220-221. 
res, que se incrementa abruptamente en 1981 cuando alcanza 2002 millones de dólares. Aproximadamente igual es el desenvolvimiento del Banco Nacional de Comercio Exterior que pasa de 295 millones a 1312 millones de dólares en el transcurso de un año. Ninguna de estas instituciones, hasta 1980, había superado la constante entre 1000 y 3000 millones de dólares de deuda anual; incluso la petrolera estatal Pemex en 1980 registra una cifra casi insignificante: 157 millones de dólares en compromisos externos de corto plazo. Pero, entre ese año y el siguiente, se convierte en la empresa que mayores adeudos contrató: en 1981 alcanzó el techo de los 4063 millones, cuando nunca había superado los 400 millones de dólares (cuadro 4).

La dimensión que adquirió la empresa petrolera estatal en esos años da una idea de la importancia e intensidad de la petrolización de la economía. Pemex cubría, en 1980, casi el $40 \%$ de todos los pagos de México por concepto de intereses de la deuda externa. Asimismo, de las amortizaciones de capital, los recursos provenientes de la empresa petrolera estatal llegaron al $82 \%$. Ese mismo año participó con el $19 \%$ de la inversión bruta fija del país y aportó la cuarta parte del total de la recaudación tributaria de la Federación. Casi un $30 \%$ de los gastos del sector público federal fueron también originados en compras de Pemex.

No obstante, tal vez lo más destacado de la participación de la paraestatal petrolera en la economía mexicana se deba a las transferencias indirectas que promovió durante el auge de la gestión lópezportillista. Pemex fue durante esos años el canal a través del cual se sostuvieron condiciones de privilegio para la adquisición de energéticos por parte de la iniciativa privada nacional y extranjera radicada en el país, tanto por intermedio de precios subvencionados como a través de contratos de obra y compra y venta de bienes y servicios.

Los enormes yacimientos petroleros mexicanos cumplían, sin embargo, un papel político - a la par que el citado económico - sólo mensurable a partir del marco de la situación internacional. 


\section{CUADRO 4}

OBLIGACIONES DEL SECTOR PÚBLICO FEDERAL POR DEUDA EXTERNA A PLAZO DE UN AN̄O O MÁS POR DEUDOR FINAL

(Millones de dólares)

\begin{tabular}{lrrrrrrrrr}
\hline & 1980 & 1981 & 1982 & 1983 & 1984 & 1985 & 1986 & 1987 \\
\hline TAL & 32322 & $42207^{2}$ & 48548 & 52779 & 68994 & 71626 & 73957 & 80846 \\
tor Gobierno & 5953 & 7646 & 13122 & 17591 & 25225 & 25963 & 31 & 107 & 35052 \\
bierno Federal & 5622 & 7234 & 12476 & 16963 & 24653 & 25634 & 30779 & 34904 \\
F & 231 & 329 & 580 & 565 & 511 & 187 & 186 & 6 \\
PFCE & 100 & 83 & 66 & 63 & 61 & 142 & 142 & 142 \\
npresas Públicas & 26 & 369 & 34561 & 36427 & 35188 & 43769 & 45663 & 42850 & 45794 \\
lancieras & 8898 & 10910 & 10768 & 9956 & 14275 & 13947 & 17700 & 19821 \\
financieras & 17471 & 23651 & 25659 & 25232 & 29494 & 31716 & 25120 & 25903 \\
ntroladas presupuestalmente & 15834 & 21493 & 22686 & 22008 & 26704 & 28644 & 22451 & 23214 \\
controladas presupuestalmente & 1637 & 2158 & 2973 & 3224 & 2790 & 3072 & 2699 & 2689 \\
tor Eléctrico & 6804 & 8225 & 8142 & 8025 & 7232 & 8200 & 1853 & 3277 \\
tor Ferrocarriles & 366 & 407 & 428 & 473 & 468 & 1178 & 1202 & 1217 \\
lex & 7467 & 11414 & 12558 & 12171 & 15802 & 15280 & 14829 & 15593 \\
ninos y Puentes Federales & & & & & & & & \\
ngresos & 101 & 75 & 50 & 46 & 36 & 86 & 86 & 86 \\
naves de México & 14 & 13 & 2 & 26 & 84 & 74 & 38 & 32 \\
\hline
\end{tabular}


Continúa CUADRO 4

\begin{tabular}{lrrrrrrrr}
\hline & 1980 & 1981 & 1982 & 1983 & 1984 & 1985 & 1986 & 1987 \\
\hline Fertimex & 265 & 422 & 367 & 376 & 600 & 823 & 806 & 797 \\
Conjunto Sahagún & 164 & 190 & 219 & 116 & 90 & 133 & 122 & 122 \\
Inmecafé & & & & & & & & \\
Sicartsa & 255 & 193 & 290 & 351 & 586 & 1003 & 1274 & 1550 \\
Productos Pesqueros Mexicanos & 29 & 27 & 11 & 11 & - & - & - & - \\
Conasupo & 369 & 527 & 619 & 401 & 1336 & 1353 & 1365 & 146 \\
PIPSA & & & & 6 & 6 & 41 & 41 & 40 \\
Siderúrgica Mexicana & & & & & 24 & - & - & - \\
AHMSA & & & & & 441 & 473 & 478 & 354 \\
Fundidora Monterrey & & & & & & & 357 & - \\
Sistema de Transporte Colectivo & 752 & 730 & 897 & 934 & 941 & 1103 & 1170 & 1160 \\
Telmex & 525 & 1045 & 1633 & 1876 & 1812 & 1964 & 1523 & 1523 \\
Otros $^{2}$ & 2462 & 2642 & 2292 & 2264 & 3734 & 4831 & 4268 & 4289 \\
Nacional Financiera, S.A. $_{\text {Banobras }}$ & 1730 & 1906 & 2053 & 1711 & 910 & 361 & 1066 & 1458 \\
Banco Nacional Agropecuario $^{3}$ & 1281 & 1616 & 1994 & 1894 & 2927 & 2570 & 2560 & 2474 \\
Fideicomiso del Gobierno Federal $^{3}$ & 861 & 1522 & 1198 & 1237 & 1413 & 2172 & 5908 & 6827 \\
Otros $^{3}$ & 2564 & 3224 & 3231 & 2850 & 5291 & 4013 & 3898 & 4843 \\
\hline
\end{tabular}

FUENTE: SHCP, y Miguel de la Madrid Hurtado. VI Informe de Gobierno 1988 y anexo Estadístico.

' Desde 1984 AHMSA y Fundidora Monterrey forman parte del sector paraestatal controlado.

${ }^{2}$ En 1975 se fusionó el Banco Nacional de Crédito Rural.

${ }^{3}$ Incluye siete millones de dólares por concepto de variaciones en el tipo de cambio y otros ajustes. 
El informe presentado en noviembre de 1980 a Ronald Reagan por miembros del Comité de Energía y Recursos Naturales del Senado estadounidense titulado: La Geopolítica del Petróleo, es sumamente revelador:

México y Venezuela son los más importantes entre los países con posibilidades de ofrecer a Estados Unidos y nuestros aliados significativas oportunidades de reducir la dependencia económica del petróleo y de Medio Oriente. Nuestro país debería demostrar su voluntad para impulsar con México una asociación naturalmente benéfica que incluye el desarrollo energético mexicano. Asimismo debería alentar a México para crear una sobrecapacidad instalada de producción de petróleo, que pudiera utilizarse rápidamente, a fin de aumentar las exportaciones durante una emergencia energética internacional. ${ }^{46}$

\section{La Deuda Privada y el Grupo Alfa}

El Estado, frente a la variable dinamizadora que fue el petróleo y el uso indiscriminado del endeudamiento externo para proseguir ferozmente el proceso de acumulación de capital, propició una concentración y centralización de grupos económicos en el sector bancario e industrial. A tal grado que

diez grupos significaron, a diciembre de 1981, un tercio del saldo de la deuda privada externa total; diez grupos representaron, en diciembre de $1981,17.5 \%$ del saldo de financiamiento total al sector privado, y $32.5 \%$ del financiamiento neto total al sector privado en 1981; los mismos diez grupos (más Frisco) absorben casi $20 \%$ del financiamiento preferencial otorgado por el Estado entre 1977 y $1980 .{ }^{47}$

La disputa más fuerte entre los grupos económicos y el Estado se ve reflejada, quizás, al mostrar el inusitado crecimiento que tiene la deuda externa del sector privado durante los últimos años del sexenio lópezportillista. En octubre de 1979

46 Carmona, Fernando. Estrategia, núm. 41, México, p. 27.

${ }^{47}$ Cardero, María Elena y José Manuel Quijano. "Expansión y estrangulamiento financiero 1978-1981", en La Banca: Pasado y Presente. Ensayos del Centro de Investigación y Docencia Económica, México, 1983. 
la deuda externa bancaria del sector privado sumaba 8800 millones de dólares. De este monto, $46.5 \%$ se contrató a corto plazo y $52.5 \%$ a largo plazo. Al tomar en cuenta que el crecimiento promedio anual de esa deuda ha sido de $30 \%$, calculamos que para 1980 llegó a 12 mil millones de dólares. Si además se suman los créditos de proveedores y de otras empresas, se puede calcular que, para esa fecha, la deuda externa total del sector privado mexicano ascendía a 15 mil millones de dólares, o sea aproximadamente $30 \%$ de la deuda externa total del país. Estos datos del Banco de México sirven como un indicador aproximado de la deuda externa del sector privado y nos ayudan a establecer su importancia por su tamaño y por el crecimiento acelerado reciente. ${ }^{48}$

Los datos anteriores muestran la disputa por el equivalente general entre el Estado y los grupos económicos ante la necesidad de proseguir el proceso de reproducción de capital. No obstante que el Estado no fue coherente con una política monetaria y financiera, que permitiera lograr un equilibrio favorable para todos los elementos de la sociedad. La fuga de divisas, el desplome de los precios del petróleo y el cercano cambio sexenal fomentó una política de subvaluación contradictoria a los intereses del propio capital.

En consecuencia, la necesidad de una devaluación drástica y profunda impactó sobre los grupos dominantes ver convertidos sus pasivos en dólares, mayores a sus activos.

Así, el excesivo endeudamiento externo privado se convirtió en problema crítico para la estabilidad económica del país. De hecho, el poderoso Grupo Alfa, integrado por decenas de empresas industriales y financieras, con su quiebra marcó el punto de inflexión entre el ciclo económico de acelerado crecimiento que se prolongó hasta 1981 y la declinación hacia la crisis que sobrevendría en 1982. El Grupo caería víctima de las reducciones impuestas al gasto público en los últimos

${ }^{48}$ Molina Warner, Isabel. "El endeudamiento externo del sector privado y sus efectos en la economía mexicana", en Comercio Exterior, vol. 31, núm. 10, México, octubre de 1981 . 
tramos del periodo lópezportillista, pero, principalmente, por la contratación masiva de préstamos, que elevaría de manera insostenible el pasivo en dólares contraído a instancias del boom petrolero de años antes. Los créditos logrados por la empresa en el exterior - avalados por el gobierno y con apoyo de las exportaciones de hidrocarburos-, cuando las divisas eran relativamente baratas y las tasas de interés inferiores a las nacionales, alcanzaron 2300 millones de dólares, lo que significaba el $70 \%$ de su pasivo total. Después de la primera devaluación, el adeudo del Grupo Alfa se elevó a 1.33 pesos por cada peso de capital contable.

El desarrollo espectacular y la estrepitosa caída del Grupo resumió en pocos datos la situación por la que atravesaba el conjunto de la nación desde los comienzos de la administración 1976-1982. La cantidad de empresas integrantes del Grupo Alfa se elevó, en cuatro años, de 37 a 155; el número de sus acciones aumentó 52 veces y su valor se multiplicó por cinco en el mismo periodo. Sus activos crecieron dando una ganancia que se elevó a una tasa del $8 \%$ anual. Para detener la curva descendente de la empresa, el Estado mexicano contrató préstamos externos: adquirió unas 15 subsidiarias, entre ellas la Fundidora de Fierro y Acero Monterrey, los bancos Internacional y Mexicano y otras que pasaron a ser administradas por Somex y Nacional Financiera, en un intento oficial por posponer la quiebra y evitar un conflicto social. Pero la caída de los precios petroleros, la devaluación del peso y la inflación interna precipitaron la crisis del Grupo que se produjo a fines de 1982 .

Otros elementos que acentúan la comparación entre la quiebra de Alfa y el comportamiento de la economía nacional lo constituyen los préstamos que el gobierno efectuó al Grupo. En octubre de 1981, 480 millones de dólares le fueron prestados a través de Banobras: una verdadera subvención destinada a postergar el impacto político y social de un colapso ya inevitable. 
El estallido de la crisis

A mediados de 1981 hay una serie de cambios en el gabinete de López Portillo que caracterizaron la crisis. Primero fue la renuncia de Jorge Díaz Serrano, director general de Pemex, vencido por una esperada y leve caída del precio del petróleo mexicano. Desequilibrios en la balanza de pagos y el impulso al ritmo inflacionario cerraron ese año y abrieron un 1982 con nuevos precios decretados en diciembre y "la cuesta -inflacionaria- de enero" que se reveló como grave coyuntura cuando al mes siguiente, al retirarse el Banco Central del mercado de cambios, se precipitó una gran devaluación del peso mexicano. El gobierno relevó de sus puestos al Secretario de Hacienda, David Ibarra Muñoz y al Director del Banco de México, Gustavo Romero Kolbeck. ${ }^{49}$

En abril se fijó una nueva paridad en el tipo de cambio: 45 pesos por dólar lo que significó una devaluación de alrededor del $67 \%$ del signo mexicano. Pero la crisis no cedía. El presupuesto se redujo en un $3 \%$ neto. Los aranceles de 1500 artículos básicos se redujeron; se flexibilizó la política de interés y tipo de cambio y, una semana más tarde, Silva Herzog anunció mayor restricción del gasto público (8\%) y un programa de ajuste económico que preveía bajar el déficit del sector público en $3 \%$ y a su vez limitar el endeudamiento público externo a 11 mil millones de dólares y aumentar los ingresos estatales por vía de incrementos en precios y tarifas de servicios, amén de establecer límites a las importaciones.

El programa de ajuste desató una serie de presiones: los incrementos salariales de marzo se trasladaron a los costos; se redujeron los ingresos fiscales por efecto de la propia crisis; la inflación más elevada condujo a un mayor gasto corriente y de inversión al incrementarse los precios de bienes y servicios, en especial los importados. 
La paridad del tipo de cambio fijada en abril volvió a derrumbarse en agosto; se fijaron dos nuevas paridades, preferencial (49.50 pesos) y ordinaria $(69.50)$ y, simultáneamente, se emitió el decreto estableciendo que las obligaciones en dólares a cargo de los bancos, debían ser liquidadas en moneda nacional.

Esta conversión dio origen a los llamados "mex-dólares", intransferibles al exterior y creados para evitar la continua fuga de divisas que estaba desangrando la economía ante la incertidumbre que provocaban los sorpresivos golpes de timón de la conducción económica. La situación parecía estar fuera de control y esta impresión se consolidó cuando el secretario de Hacienda, en la tercera semana de agosto, solicitó a los más importantes bancos comerciales extranjeros acreedores de México, una prórroga de 90 días para los pagos de la deuda del sector público. El lapso sería aprovechado por las autoridades mexicanas para elaborar un proyecto de reestructuración "definitiva" del perfil de la deuda externa. Para entonces, ya se conocía que México había iniciado conversaciones con el FMI a fin de utilizar los recursos disponibles en su calidad de miembro del organismo (unos 3500 millones de dólares).

La moratoria solicitada por México fue aceptada por los banqueros internacionales, pero restringida a la deuda pública: los bancos privados mexicanos quedaron al margen de la medida y a la espera del auxilio oficial.

Al restablecerse las operaciones en el mercado de cambios el 19 de agosto, mientras el tipo preferencial seguía devaluándose a razón de cuatro centavos diarios, el juego especulativo llevó a la divisa a más de 100 pesos. El 1 de septiembre, al fin, se decretó el establecimiento del control generalizado de cambios: prohibía la importación y exportación de divisas, operaciones que quedaban bajo el monopolio del Banco de México. Pero ante la escasez de dólares la situación se agravó. En algunos puntos fronterizos del lado estadounidense se constituyó un amplio mercado de pesos cuyas cotizaciones sirvieron de guía al mercado ilegal que se desenvolvió 
rápidamente en territorio nacional. Se prohibió entonces la exportación de moneda. Pero en pocos días la mayor parte de las operaciones cambiarias se habían trasladado a la frontera y era escasa la actividad del mercado controlado. Las importaciones, además, se redujeron al mínimo repercutiendo sobre la actividad económica.

La crisis cambiaria fue el motivo aludido por la administración al momento de decretar la nacionalización de la banca, ese mismo 1 de septiembre de 1982, pero del propio mensaje presidencial surgen una serie de antecedentes, mucho más graves, que obligan a tomar la medida gubernamental. "Tenemos que detener la injusticia del proceso perverso fuga de capitales-devaluación-inflación"' dijo López Portillo. Y abundó en datos:

las cuentas en bancos mexicanos denominadas en dólares, pero nutridas original y mayoritariamente en pesos, son del orden de los $12 \mathrm{mil}$ millones de los llamados "mex-dólares": de la economía mexicana han salido, en los últimos dos y tres años, por lo menos 22 mil millones de dólares y se ha detectado una deuda privada no registrada para liquidar hipotecas por unos 20 mil millones de dólares más, que se adicionan a la deuda externa del país; en total 54 mil millones de dólares alrededor de dos tercios de la deuda pública y privada documentada del país eludiendo al fisco e instalándose definitivamente en Estados Unidos; estos rentistas mexicanos hicieron inversiones en el extranjero que sobrepasan cuatro veces la realizada en el propio país. ${ }^{50}$

Se expropian los activos de 54 bancos que juntos ocupaban a más de 150 mil empleados y cuyos recursos totales ascendían a dos billones 400 mil millones de pesos. Más de la mitad de estos activos correspondían a Banamex y Bancomer; con Serfín y Comermex hacían las tres cuartas partes del total expropiado. El Estado duplicó su participación en la posesión de activos bancarios quedando dueño de compañías de seguros, casas de bolsa y arrendadoras, pero también de empresas comerciales e industriales y asumió el compro-

${ }^{50}$ López Portillo, José. Sexto Informe de Gobierno. 
miso de pagar todos y cada uno de los créditos que tuvieron a su cargo las instituciones expropiadas para pagar a sus accionistas y hacerse cargo de las indemnizaciones correspondientes en plazo no mayor de una década.

Independientemente del hecho político y del significado histórico de la expropiación de la banca privada mexicana, la medida privó del control de un poderoso aparato a grupos y consorcios ligados a la especulación financiera que estaban desestabilizando la economía del país (al menos en ese momento).

Por las reacciones que provocó, resulta evidente que golpeó duramente a algunos sectores de la clase empresarial mexicana pero no hay que olvidar que el Estado los compensaría rápidamente con generosas indemnizaciones. Lo importante radicaba en que el gobierno había logrado - de momentoclausurar una de las válvulas más activas en la fuga de capitales; lo trascendente consistía en haber recuperado un aparato que históricamente cobijó a lo más conservador y reaccionario de la sociedad mexicana. De paso el gobierno contaría con nuevas fuentes de financiamiento para sus crecientes gastos y podría ejercer una mejor vigilancia del sistema financiero nacional cuando las exigencias de la banca mundial lo apremiaran. 



\section{ENDEUDAMIENTO MULTILATERAL}

El presente capítulo tiene por objeto vincular de manera empírica el destino que ha tenido el equivalente general hacia los distintos sectores en la reproducción de capital nacional, bajo el marco del proceso de acumulación internacional.

Ubicaremos nuestra atención en el flujo de capital otorgado por las instituciones multilaterales y bilaterales.

\section{Características de la deuda externa en los años cuarenta y cincuenta}

Durante la confrontación bélica, el Estado se vio fortalecido frente al proceso interno de acumulación, consolidó deudas anteriores y efectuó pagos a los capitalistas extranjeros por concepto de indemnización de las expropiaciones petroleras y de los ferrocarriles. El presidente Manuel Ávila Camacho en su último informe de gobierno diría “...de este modo y resuelto el viejo problema de la deuda externa, puede afirmarse que íntegramente la deuda pública está al corriente y su crédito restablecido pues el muy pequeño saldo de la deuda bancaria será objeto de ajuste equitativo". ${ }^{1}$

${ }^{1}$ El 1 de septiembre de 1943, Manuel Ávila Camacho informó a la nación lo siguiente: "El 5 de noviembre de 1942 se celebró un Convenio con el Comité Internacional de Banqueros para el ajuste de capital, pago de intereses y amortización de la deuda pública exterior. Por virtud de él, se reduce el capital de las deudas a un peso por dólar y se ajustan las tasas de intereses. La deuda total será de 10 millones de pesos anuales, para disminuir progresivamente a medida que se rescaten los títulos, en la inteligencia de que para ese efecto, así como para la compra de los derechos por intereses vencidos durante el periodo de suspensión de los servicios, se utilizarán los fondos que obran en poder del Comité de Banqueros de Nueva York. El Gobierno se obligó a que los bonos que queden 
En el ámbito internacional, la hegemonía alcanzada por Estados Unidos una vez terminada la guerra, hizo posible que en el campo financiero se fortaleciera el Banco de Exportación e Importación de Estados Unidos (Eximbank). El objetivo del Eximbank cristalizado como equivalente general, consistió en agilizar las exportaciones de mercancías y promover la compra de los productos estadounidenses. Incluso, en el mismo discurso del Informe presidencial de Miguel Alemán se hizo énfasis en el criterio general respecto a créditos internacionales.

Este ha sido el de solicitar sólo aquellos que no constituyen una carga para las generaciones futuras, ya sea porque las obras mismas desarrolladas den lugar a ingresos propios para su pago o ya porque el incremento directo que las obras provoquen en la riqueza del país permita su fácil amortización. ${ }^{2}$

Por otro lado, la constitución del Fondo Monetario Internacional (FMI) y el Banco Internacional de Reconstrucción y Fomento (BIRF) creados en 1944, iniciaron la conformación de la red financiera a nivel internacional bajo el emporio del dólar y el condicionamiento de la ayuda financiera, préstamos y créditos a favor del proceso de acumulación capitalista, en manos de grandes inversionistas privados estadounidenses. ${ }^{3}$

\section{Consolidación de deudas anteriores}

La utilización de la deuda externa contratada por el gobierno mexicano durante el periodo de posguerra y hasta finales de los cincuenta, presenta las siguientes características.

en circulación en el año de 1968 serán redimidos conforme a su valor ajustado. El valor total nominal de estas emisiones, que era de 264669277 dólares por capital y 278884248 dólares por intereses, el 31 de diciembre de 1942, después del convenio, queda reducida a 230631974 pesos por capital, y algo más de dos millones de dólares por intereses". Cf. Secretaría de Hacienda y Grédito Público, Secretaría de la Presidencia, México a través de los Informes Presidenciales, "La Hacienda Pública", tomo IV, vol 2, México, 1976.

${ }^{2}$ Ibid. p. 589.

${ }^{3}$ Ibid., 5 de noviembre de 1942. 
Deuda directa. Durante la administración del gobierno del general Manuel Ávila Camacho se celebró un convenio con el Comité Internacional de Banqueros de Nueva York. En virtud de sus postulados, la deuda directa se redujo a un peso por dólar y se ajustaron las tasas de interés. De ahí que el valor nominal de dichas emisiones con valor de 264669277 dólares por capital y 278884248 dólares $^{4}$ por intereses al 31 de diciembre de 1942 se vieron reducidas a 230631974 por capital y, por intereses, cerca de dos millones de dólares. ${ }^{5}$

Deuda ferrocarrilera. Siguiendo los lineamientos de los convenios de la deuda directa se concretó con el Comité Internacional de Banqueros con negocios en México, un acuerdo para refinanciar la deuda ferrocarrilera. Las características de este convenio cubrieron las 19 emisiones de la deuda de los ferrocarriles por un monto nominal, incluyendo capital e intereses, de 557604382 dólares. Esta cantidad se redujo posteriormente hasta representar la cantidad de 244971707 pesos. ${ }^{6}$

La deuda de la Revolución. La deuda de la Revolución ascendía a 21.5 millones de dólares; para finales de los años cuarenta, únicamente faltaban por pagar 2.5 millones de dólares de acuerdo con los convenios establecidos con Estados Unidos, Gran Bretaña, Francia e Italia para liquidar los daños causados a los extranjeros por la lucha revolucionaria. ${ }^{7}$

\section{Endeudamiento con instituciones oficiales}

Contratación de créditos con Eximbank. La contratación de préstamos con bancos de carácter oficial se inició en el año

${ }^{4}$ El tipo de cambio era de un dólar igual a 4.85 pesos.

${ }^{5}$ Los organismos financieros internacionales fueron creados después de la segunda guerra mundial con objeto de reconstruir principalmente Europa y dar algunos préstamos a América Latina y otras regiones para evitar problemas sociales. Estos organismos fueron el FMI y el BIRF.

6 México a través... 20 de febrero de 1946.

${ }^{7}$ Cf. Informes presidenciales de la época. 
de 1941 a través de Eximbank, el cual suscribió, con la intermediación de Nacional Financiera, dos préstamos a la Secretaría de Comunicaciones y Obras Públicas: un crédito para caminos por valor de 10 millones de dólares al tipo de interés del $3.6 \%$ anual, y otro por valor de 20 millones de dólares. Posteriormente con el mismo objeto se contrató otro préstamo por un valor de 10 millones de dólares, Ferrocarriles $\mathrm{Na}$ cionales de México suscribió con el Eximbank un préstamo por siete millones de dólares en 1943 y otro por 19 millones en 1945. Los demás créditos fueron canalizados a la industria: Altos Hornos de México, S. A.; Compañía Azucarera del Río Guayalejo, S. A.; Enlatadoras de Carne; Nueva Compañía Eléctrica de Chapala, S. A.; Maquinaria Agrícola, S. A.; La Consolidada, S. A. Dichos préstamos hasta antes de 1960 , ascendieron a 63 millones de dólares y fueron canalizados a través de Nacional Financiera para la realización de obras industriales de interés nacional, como las de electrificación y rehabilitación de los ferrocarriles e instalaciones petroleras. $^{8}$

Contratación de créditos con el BIRF. México tuvo acceso a créditos de carácter multilateral a partir de 1944 . No obstante, continuó el endeudamiento mediante contratos de carácter bilateral con el Eximbank.

Una de las primeras entidades mexicanas en suscribir préstamos con el BIRF fue Nacional Financiera con un crédito por 24.1 millones de dólares para la Comisión Federal de Electricidad (CFE), destinado a la construcción de sistemas hidroeléctricos. El BIRF canalizó 134.8 millones de dólares a la industria durante la década de los cincuenta. Se destinaron al sector servicios 61 millones de dólares a través de un programa de rehabilitación y modernización. ${ }^{9}$

\footnotetext{
${ }^{8}$ Ibid.

${ }^{9}$ Véanse las diversas publicaciones de Nacional Financiera, en especial $\mathrm{El} \mathrm{Mer-}$ cado de Valores, varios años.
} 
Ayuda financiera otorgada por el FMI. Las condiciones internacionales imperantes durante la posguerra ocasionaron un reajuste en nuestra economía y la necesidad de acudir a la "ayuda financiera" del FMI. El peso mexicano tuvo tres devaluaciones durante un periodo de seis años. En 1948, la moneda cuya paridad con el dólar era de 4.85 se dejó al libre juego de la oferta y la demanda de divisas hasta alcanzar un nuevo tipo en 1949 de 8.65 pesos por dólar. ${ }^{10} \mathrm{El}$ Fondo ofreció ayuda adicional de 67.5 millones de dólares cuyo destino fue apoyar el nuevo tipo de cambio. Se exigió restringir las importaciones, alentar las exportaciones y el turismo, estimular la repatriación de capitales y fomentar la reinversión de los ahorros. Sin embargo, el préstamo, al final fue sólo de 22.5 millones de dólares.

De nueva cuenta, después de mostrar saldos positivos de 31 millones de dólares en 1949 y de 60 millones en 1950, ante el clima de intranquilidad de principios de los cincuenta, la balanza de pagos en cuenta corriente dejó un saldo adverso de 101 millones de dólares en 1951, de 47 millones en 1952 y de 82 millones en 1953. La situación de la balanza comercial siguió agravándose en los primeros meses de 1954, consecuencia de las importaciones necesarias para el proceso interno de acumulación y de la articulación de nuestras exportaciones con la baja de precios en el mercado internacional.

La recesión presentada en Estados Unidos al finalizar la guerra de Corea tuvo efectos negativos en la economía mexicana. Los precios de exportación disminuyeron en $14.1 \%$ y los precios de importación aumentaron $9.8 \% ; ;^{11}$ de tal forma que incidieron en el empobrecimiento de la balanza de pagos. En consecuencia, ante tal situación las autoridades monetarias del país decidieron, previo permiso del FMI, devaluar el peso mexicano en abril de 1954 al tipo de cambio de 12.50 pesos por dólar. ${ }^{12}$

${ }^{10}$ México a través...

${ }^{11}$ Manrique, Irma. La politica monetaria en la estrategia del desarrollo. Cuadernos Preliminares de Investigación, IIEc, UNAM, p. 123

12 Ibid., p. 134. 
El FMI puso a disposición de México 50 millones de dólares: 22.5 millones representaban la aportación de nuestro país y 27.5 millones de un crédito adicional. Se destinaron además 75 millones de dólares del convenio de estabilización del gobierno estadounidense. Las tres líneas de crédito formaron una suma de 102.5 millones de dólares para completar los recursos propios del Banco de México. El plan de emergencia, sugerido por el FMI permitió que el financiamiento del gobierno se orientara a la industria mediante subsidios fiscales, facilitando la inversión privada.

Canalización de créditos de origen oficial. Durante los años cuarenta y cincuenta el financiamiento proveniente de los organismos oficiales se canalizó al sector secundario en $45.3 \%$ $\mathrm{y}$ al sector servicios en $45.8 \% .{ }^{13}$ El financiamiento coincidió con los lineamientos de la política económica llevada a cabo en México en este periodo: promover la industrialización y crear una infraestructura en las vías de comunicación. En el mismo orden "...la inversión extranjera realizó una reorientación básica de su actividad, trasladándose de la agricultura y las industrias extractivas a la industria manufacturera $y$ el comercio en gran escala". ${ }^{14}$

Este periodo “....coincidió con la nueva actividad imperialista de Estados Unidos empeñado en afianzar su posición de líder en el mundo occidental". ${ }^{15}$ Por eso la inversión directa en los sectores de punta estuvo financiada en gran parte con préstamos provenientes del exterior: "Las inversiones extran-

${ }^{13}$ Los porcentajes para señalar la canalización de los créditos de origen oficial se obtuvieron tomando en cuenta cada préstamo otorgado a México por los organismos financieros internacionales y separándolos por sectores. La suma del total entre la diferenciación sectorial es el resultado de los porcentajes. Para tal efecto se utilizaron las cifras vertidas en diferentes números de El Mercado de Valores. ${ }^{14}$ Cordera, Rolando. "Estado y desarrollo en el capitalismo tardío y subordinado", en Investigación Económica, vol. XXXI, julio-septiembre de 1971, núm. 123, UNAM, p. 470.

${ }^{15}$ Chapoy, Alma. "Las Inversiones Extranjeras Directas en el Sexenio de Echeverría". En Investigación Económica, FE, UNAM, octubre-diciembre de 1977, núm. 4, p. 49. 
jeras directas complementadas con fuertes créditos otorgados por agencias norteamericanas o por organismos supuestamente internacionales, pero controlados por Estados Unidos, se convirtieron entonces en el instrumento clave para satisfacer los deseos estadounidenses de dominación política" ${ }^{16}$

El Eximbank y el Banco Mundial (BM) contribuyeron con el $70.0 \%$ y el $28.4 \%$ respectivamente del componente total de la deuda pública externa. La otra institución participante fue el FMI, el monto del préstamo de carácter estabilizador ascendió aproximadamente en 67.5 millones de dólares, su objetivo fue enfrentar los problemas de balanza de pagos.

\section{Periodo de pre-crisis mundial}

Los periodos centrales de nuestro análisis son los comprendidos entre los años de 1968-1976 y 1977-1987. El primero lo hemos dividido en dos subperiodos: 1968-1972, en que las magnitudes económicas reflejan un cambio de las tendencias prevalecientes en el periodo de pre-crisis 1960-1967, en gran parte derivadas de la que se inicia a nivel mundial; en el segundo subperiodo, 1973-1976, hay un rasgo definitivo que se expresa en una expansión sin precedentes de la deuda externa de México, hasta culminar con la devaluación monetaria de 1976.

Captar estos fenómenos, empero, implica revisar, cuando menos en líneas muy generales, las tendencias prevalecientes en el periodo anterior que nos permitimos llamar de precrisis. En forma un tanto arbitraria, pero tomando en cuenta el modelo de acumulación de capital y las características que asume el desarrollo económico, hemos tomado como marco temporal 1960-1967, años en que las magnitudes económicas exhiben tendencias que estadísticamente podríamos llamar normales y en que la deuda misma se comporta dentro de ciertos límites. 
Variaciones absolutas y relativas de la deuda externa

El cuadro 5 contiene el comportamiento, tanto absoluto como relativo, de la deuda pública externa total en el periodo 1960-1967. En términos absolutos, se produce un crecimiento que va de 1151 a 2643 millones de dólares. En términos relativos, tales cifras estarían expresando una tasa promedio anual de crecimiento de $11.26 \%$ y una tasa acumulativa de crecimiento de 90.1 por ciento.

Es importante, sin embargo, detenerse un tanto en la tendencia que expresan en términos relativos cada uno de los años estudiados. De tasas de 3.5 y 2.8 en los años 1961 y 1965 , se mueve a tasas de 22.3 y 21.1 en los años 1962 y 1964 respectivamente. Ellos, a nuestro juicio, están indicando una tendencia no lineal, que habría que incluir dentro de la política económica del periodo sexenal y las coyunturas externas. Contrasta, como luego veremos, con tendencias claras por lo menos en el primer subperiodo de nuestra etapa de interés.

Si extendiésemos el periodo hasta el año 1970, para tener una visión de los sexenios de López Mateos y Díaz Ordaz, lo que tendría importancia en un estudio detenido de las políticas económicas de cada uno de ellos, encontraríamos que en el régimen de López Mateos el incremento neto de la deuda fue de $186 \%$ cuando se elevó de 602 millones de dólares en 1958 a 1724 millones en el año de $1964 .{ }^{17}$ Retomando los datos del BID indicaríamos que el gobierno de Díaz Ordaz pasa de 1160 millones de dólares en 1965 a 3775 millones en el año de 1970; es decir, tuvo un incremento de $225 \%$ y se triplicó, peligrando el incremento sustancial en el servicio de su deuda externa.

${ }^{17}$ Ceceña, José Luis. México en la órbita imperial (Las empresas trasnacionales). Ediciones El Caballito, México, 1970. 


\section{CUADRO 5}

DEUDA PÚBLICA EXTERNA TOTAL: PRINCIPALES COMPONENTES 1960-1967

(Millones de dólares)

\begin{tabular}{lrrrrrrrr}
\hline & 1960 & 1961 & 1962 & 1963 & 1964 & 1965 & 1966 & 1967 \\
\hline Acreedores Privados & 574 & 609 & 729 & 905 & 1236 & 1160 & 1187 & 1503 \\
$\quad$ bonos & 19 & 16 & 16 & 55 & 127 & 150 & 184 & 255 \\
$\quad$ créditos & 555 & 593 & 713 & 850 & 1109 & 1010 & 1003 & 1248 \\
Acreedores Oficiales & 577 & 582 & 728 & 794 & 820 & 954 & 1073 & 1140 \\
$\quad$ multilateral & 187 & 206 & 362 & 430 & 481 & 608 & 658 & 660 \\
$\quad$ bilateral & 390 & 376 & 366 & 364 & 339 & 346 & 415 & 480 \\
$\quad$ & 1151 & 1191 & 1457 & 1699 & 2056 & 2114 & 2260 & 2643 \\
TOTAL & 1150
\end{tabular}

FUENTE: BID. Deuda Externa de los Países de América Latina. Departarnento de Desarrollo Económico y Social, Washington, 1987. 
Componentes generales de la deuda externa

Cuando hablamos de los componentes de la deuda nos referimos al tipo de títulos de endeudamiento conforme a la naturaleza de los organismos fuente de los recursos: los pasivos originados en operaciones de bonos créditos y préstamos realizados con organismos comerciales con sede en otros países y los oficiales cuyo origen de préstamos proviene de organismos bilaterales y multilaterales. En este apartado analizaremos el segundo componente: préstamos bilaterales y multilaterales.

\section{Canalización del crédito oficial por sectores 1960-1967}

El flujo del financiamiento proveniente de los organismos internacionales denota las siguientes características durante el periodo: ${ }^{18}$

El crédito de organismos oficiales contratados en el periodo 1960-1967 alcanzó el monto de 1308.9 millones de dólares. La mayor parte se destinó al sector secundario (606.3 millones de dólares), representando el $46.3 \%$ del total. El sector primario absorbió 418.6 millones que vendrían a ser el $32.0 \%$; y el sector terciario absorbió 283.9 millones $(21.7 \%$ del total).

El BM canalizó en total 581.5 millones de dólares. El $56.7 \%$ los destinó a la industria, $26.8 \%$ a servicios y $16.5 \%$ al sector primario.

La Corporación Financiera Internacional (CFI) asignó el $100 \%$ de sus créditos a la industria, principalmente a la iniciativa privada.

El BID aplicó 325.8 millones de dólares; el $57.6 \%$ lo absorbió el sector primario, $26.8 \%$ el de servicios y $15.5 \%$ el sector secundario.

El Eximbank canalizó el $64.4 \%$ a la industria y $35.6 \%$ al sector primario. Participó con un total de 307.6 millones de dólares durante el periodo 1960-1967.

18 Véase Informe del BID y BM (varios años). 
CUADRO 6

CANALIZACION DEL CREDITO OFICIAL

POR SECTORES: 1960-1967

(Millones de dólares)

\begin{tabular}{|c|c|c|c|c|c|c|}
\hline & BIRF & $C F I$ & $B I D$ & Eximbank & $A I D$ & TOTAL \\
\hline Primario & 96.5 & -- & 187.7 & 109.5 & 25.0 & 418.7 \\
\hline Secundario & 330.0 & 27.5 & 50.7 & 198.1 & -- & 606.3 \\
\hline Terciario & 155.0 & - & 87.4 & -- & 41.5 & 283.9 \\
\hline Total & 581.5 & 27.5 & 325.8 & 307.6 & -- & 1308.9 \\
\hline
\end{tabular}

Fuente: Nacional Financiera. El Mercado de Valores, varios números. Cuadro elaborado por la autora.

La Agencia Internacional de Desarrollo (AID) aportó 66.5 millones de dólares; el $62.4 \%$ se destinó a servicios y el $37.6 \%$ al sector primario.

De to anterior podemos concluir dos líneas en relación a la canalización de los créditos. Por un lado el sector secundario se vio beneficiado principalmente por el BM, la CFI y el Eximbank. Del otro el sector primario recibió importante atención a través del BID y la AID.

Ambos lineamientos no son contradictorios: los del primer grupo irán en estrecho vínculo a la expansión de las empresas trasnacionales en el sector secundario y los del segundo se encuentran en el marco de la Alianza para el Progreso; esto es, la ampliación del sector primario como una alternativa para evitar problemas sociales y coadyuvar a un mejoramiento en el nivel de vida de los sectores sociales. Esta línea se acentuará en años posteriores, especialmente en la década de los setenta, con la entrada de las trasnacionales a la agricultura.

Características del endeudamiento público en el periodo 1968-1976

Por las razones expuestas y por los objetivos mismos de la investigación, se abordará el análisis de este lapso central, lle- 
vando simultáneamente dos periodos; el de 1968 a 1972, que presenta tendencias más o menos coincidentes con el periodo anterior de pre-crisis ${ }^{19}$ que nos sirvió de marco general, en el sentido de mantenerse dentro de ciertos márgenes máximos y estables de crecimiento de las variables del endeudamiento y, por otro lado, el que corre de 1973 a 1976 en que el comportamiento de las mismas, tanto en términos ábsolutos como relativos, sufren notables modificaciones determinadas por factores a analizar en otro capítulo.

\section{Variaciones absolutas y relativas de la deuda global}

En el cuadro 7 hemos incluido para cada uno de los años los valores absolutos alcanzados por la deuda externa global. En lo que se refiere a los valores relativos, en primer término, hemos obtenido como base el año de 1968, primero de la serie, a fin de determinar el crecimiento acumulativo, para pasar luego a distinguir las variaciones de cada año en relación al inmediato anterior, obteniendo así las tasas acumulativas anuales de crecimiento en cada uno de los periodos.

Los datos, que complementamos en otros capítulos con el análisis cualitativo, nos permiten ver las modificaciones sustanciales que, a nivel global, se producen de uno a otro periodo.

En efecto, tomando el monto inicial total de la deuda externa como año base (1968 igual a 100), encontramos que en el año 1976 - año extremo- alcanzó un índice de 580.0, en otras palabras la deuda total se había más que quintu-

${ }^{19}$ Se analiza el periodo $1968-1972$ porque consideramos que las tendencias cualitativas y cuantitativas de la deuda externa son diferentes a partir de 1968 en razón de los rasgos que se presentan en el resquebrajamiento del sistema monetario internacional. Las fluctuaciones de las monedas europeas en relación al tipo de cambio con respecto al dólar inciden en el incremento del mercado internacional de capitales. A ello se suma la creación de liquidez con relación a los llamados "'petrodólares" en 1973. A partir de estos años y hasta 1976, dada la política interna de mantener el llamado "modelo de estabilización" mexicano, el gobierno en el poder hará del endeudamiento externo la palanca necesaria para evitar un rompimiento. Proceso que se ve interrumpido por la devaluación del peso en 1976. 


\section{CUADRO 7}

DEUDA PÚBLICA EXTERNA TOTAL: PRINCIPALES COMPONENTES 1968-1976

(Millones de dólares)

\begin{tabular}{lrrrrrrrrrr}
\hline & 1968 & 1969 & 1970 & 1971 & 1972 & 1973 & 1974 & 1975 & 1976 \\
\hline Acreedores Privados & 1821 & 2056 & 2158 & 2604 & 2788 & 4524 & 7083 & 9831 & 14030 \\
$\quad$ Bonos & 366 & 404 & 388 & 396 & 464 & 551 & 572 & 655 & 908 \\
Créditos & 1455 & 1652 & 1770 & 2108 & 2324 & 3973 & 6511 & 9176 & 11927 \\
$\quad$ Proveedores & 437 & 458 & 424 & 388 & 349 & 351 & 576 & 480 & 1500 \\
$\quad$ Bancos & 758 & 800 & 858 & 1231 & 1503 & 2958 & 5019 & 7561 & 10427 \\
$\quad$ Otras finanzas & 231 & 370 & 469 & 474 & 462 & 658 & 914 & 1135 & - \\
$\quad$ Nacionalizaciones & 29 & 24 & 19 & 15 & 10 & 6 & 2 & - & - \\
Acreedores oficiales & 1333 & 1376 & 1617 & 1703 & 1997 & 2735 & 3154 & 3649 & 4252 \\
$\quad$ Multilateral & 837 & 899 & 1126 & 1238 & 1542 & 1867 & 2221 & 2585 & 3106 \\
$\quad$ Bilateral & 496 & 477 & 491 & 465 & 455 & 868 & 933 & 1064 & 1146 \\
& & & & & & & & & & \\
TOTAL & 154 & 3432 & 3775 & 4207 & 4785 & 7259 & 10237 & 13480 & 18282 \\
\hline
\end{tabular}

FUente: BID. Deuda Externa de los Países de América Latina. Departamento de Desarrollo Económico y Social, Washington, 1987. 
plicado, pasando de 3154 a 18282 millones de dólares. El comportamiento por subperiodo, no obstante, es totalmente distinto. Siempre tomando como base 1968, el endeudamiento externo a 1972 había crecido en $51.7 \%$. Inmediatamente de iniciado el segundo subperiodo el aumento alcanza $130.1 \%$ para de allí continuar subiendo en forma galopante, hasta llegar a un índice de $580.0 \%$ en 1976 , o sea un crecimiento de $480.0 \%$ en todo el periodo. Si examinamos el crecimiento por sexenio, nos percataremos de lo siguiente: de finales de 1970 a 1976 la deuda pública externa total pasó de 3775 a 18282 millones de dólares; es decir, un crecimiento absoluto de 14507 millones de dólares o 484 por ciento.

\section{Componentes de la deuda externa total según origen oficial y privado}

Si relacionamos el incremento arriba anotado, con el comportamiento general del endeudamiento externo total en ambos subperiodos, podemos aseverar que todo este galopante endeudamiento externo del segundo subperiodo tuvo como fuente a organismos de tipo privado. El interés de los acreedores en financiar los recursos petroleros y la liquidez en el mercado internacional de capitales, hacía necesaria la valorización del capital. Ello lo acentuaremos en el siguiente capítulo al momento de reseñar la activa participación que tuvo Pemex en el mercado de eurocréditos durante 1973-1982.

\section{La deuda oficial según tipo de organismos prestatarios}

Sin menoscabo de referirnos más adelante al tipo de organismos participantes de la deuda, deseamos analizar en términos muy generales la forma en que se estableció la deuda con organismos oficiales, clasificándolos en multilaterales y bilaterales, desde dos puntos de vista: su peso en cada uno de los años del periodo y por otro lado, las tasas de crecimiento anual en el periodo, para observar muy rápidamente su correspondiente dinamismo. 
El cuadro 7 nos indica que en el cubrimiento de la deuda pública externa oficial, ha sido constante la mayor participación de los organismos multilaterales en comparación con los bilaterales. Incluso en el primer subperiodo se aprecia, muy evidente una tendencia decreciente de la participación de estos últimos. A partir de 1973, sin dejar de moverse dentro de la tendencia ya señalada, se ve un crecimiento en el componente bilateral, que se acercaría a la situación prevaleciente en 1970, aunque en los años subsiguientes la tendencia es a bajar pero siempre a un ritmo mayor que en el subperiodo 1968-1972.

$\mathrm{El}$ análisis de las tasas anuales de crecimiento de ambos componentes nos muestran su comportamiento regular aunque un mayor dinamismo se encuentra en los de fuentes multilaterales, ello sin duda obedece a las modalidades que asume el financiamiento de tipo oficial en cuanto a formas de contratación y desembolso. Llama inmediatamente la atención la brusca tasa de aumento en los bilaterales en el primer año del segundo subperiodo 1973, en que se pasa de una tasa de 2.15 a una de $90.76 \%$. A nuestro juicio, se debe a la "vuelta de la bilateralidad" en las relaciones internacionales de México - en gran medida - como un requerimiento dictado entre otras cosas por el peso de los compromisos financieros adquiridos con Estados Unidos a fin de hacer frente a los problemas de balanza de pagos y de finanzas públicas del país, tendencia que prácticamente se desvanece pues " ....México no califica para recibir buena parte del financiamiento bilateral que se ofrece en términos concesionales destinado generalmente a los países de menor desarrollo relativo"' (véase cuadro 7). ${ }^{20}$

${ }^{20}$ Green, Rosario. "La deuda pública externa de México 1965-1976", en Comercio Exterior, vol. 27, núm. 11, México, noviembre de 1977, pp. 1279-1286. 


\section{Canalización del crédito oficial por sectores 1968-1976}

\section{Endeudamiento y trasnacionalizacion de la economía}

La expansión de filiales de empresas extranjeras bajo el amparo de la Alianza para el Progreso penetraron profundamente las economías latinoamericanas durante la década de los sesenta. Países como Argentina, Brasil y México vieron copado el sector secundario en dichos años.

Lo anterior muestra cómo las empresas multinacionales o trasnacionales participaron en la formación bruta de capital fijo nacional.

En 1962, la inversión extranjera directa contribuía con el $16.0 \%$ a la formación bruta de capital fijo del sector, proporción que disminuye al $14.7 \%$ en 1976 , después del máximo, $16.5 \%$ en 1965 . Sin duda, esto se debe como razón principal, al hecho de las empresas multinacionales ( $y$ las corporaciones extranjeras en general) persiguen objetivos corporativos y mantienen políticas y estrategias constantes dado que la tasa de rentabilidad de la inversión extranjera directa pasó del $14.1 \%$ en 1962 al $18.4 \%$ en 1970 , correspondiendo al sector industrial tasas del $15.7 \%$ y del $19.4 \%$ en los mismos años, por lo que no cabe aducir problemas financieros de las subsidiarias locales.

La participación de las empresas trasnacionales en el sector manufacturero fue de vital importancia para la reproducción del capital en los años sesenta. Se ligaron al sector agrícola mediante la fabricación de insumos como tractores, maquinaria agrícola, fertilizantes, etc. vía sus filiales. De allí la importancia del financiamiento de carácter oficial en el periodo estudiado, donde las empresas trasnacionales y los organismos financieros van dominando la esfera productiva y distributiva del proceso de acumulación nacional. Conformando una nueva fase del gran capital, apoyado en las corporacio-

${ }^{21}$ Bernal Sahagún, Víctor Manuel. "La inversión extranjera directa, las empresas multinacionales y los ingresos en México" en Investigación Económica, FE, UNAM, núm. 143, 1978, p. 31. Conviene mencionar el lema que caracterizó a este periodo en nuestro país: "Lo hecho en México está bien hecho". 
nes multinacionales, que conllevaron una división internacional del trabajo diferente.

\section{Características del financiamiento al sector primario}

La crisis alimentaria mundial en 1973 vino a desarrollar nuevas pautas de consumo y por consiguiente nuevos giros de inversión. El incremento de la producción de alimentos fue la nueva estrategia que en algunos países de América Latina y en México impulsará la inversión externa, sólo que los beneficios de dicha producción fueron canalizados hacia el exterior a través de productos no tradicionales más competitivos en el mercado internacional en vez de aliviar la penuria de los grupos sociales más desposeídos del Tercer Mundo. ${ }^{22}$

No es una casualidad que el Estado mexicano, a través de Nacional Financiera en el periodo 1968-1976 haya privilegiado al sector primario mediante los préstamos de la banca oficial. En efecto, el sector primario recibió el $43.2 \%$ del total del financiamiento gubernamental; el $30 \%$ le correspondió al secundario y el $25.3 \%$ al terciario. Esta tendencia, a nuestro juicio, está latente desde los años sesenta; se ve claramente definida en el subperiodo 1973-1976 en que el sector primario suscribió el $48.7 \%$ del total de la deuda contratada con organismos oficiales, contra el $27.5 \%$ para el secundario y el $23.8 \%$ para el terciario. Este viraje obedeció a la cada vez mayor participación del sector agrícola (riego, transporte, insumos), para favorecer a la inversión extranjera en la agroindustria (cuadro 8).

El interés del BM y del BID en canalizar sus préstamos hacia el sector primario, en el caso de México, es importante por ser un país con abundantes recursos naturales. Además, al norte del país se entrelazan los intereses de la oligarquía

${ }^{22}$ Cf. Arroyo, Gonzalo. "Firmas Trasnacionales, Agro-Industrias, Reforma Agraria y Desarrollo Rural', en Investigación Económica, núm. 147, enero-marzo 1979, pp. 9-47. El autor argumenta la hipótesis para resaltar que dicho proceso pasa de un "modelo de sustitución de importaciones" a un "modelo agro-minero exportador". 


\section{CUADRO 8}

CANALIZACIÓN DEL CRÉDITO OFICIAL POR SECTORES: 1968-1976 (Millones de dólares)

\begin{tabular}{lrrrrrr}
\hline & BIRF & CFI & BID & Eximbank & AID & TOTAL \\
\hline Primario & 834.0 & - & 661.1 & $-\bar{r}$ & - & 1495.1 \\
Secundario & 640.0 & 40.8 & 170.0 & 184.2 & - & 1035.1 \\
Terciario & 471.3 & - & 232.9 & 169.8 & - & 874.0 \\
No especificados & 1945.3 & 40.8 & 1064.0 & 404.0 & 0.1 & 50.1 \\
Total & & & & &
\end{tabular}

FUENTE: El Mercado de Valores. Cuadro elaborado por la autora. 
financiera y sus agencias con la creación de una infraestructura para la agricultura, de la que también se aprovechan las tradicionales agroindustrias con interés de exportar; en tanto, los grupos sociales beneficiados dentro del país, corresponden a una burguesía nacional fuerte, ligada a los intereses estadounidenses.

Los créditos en este sector se ubican en dos líneas bien definidas: la creación de zonas de riego y el fomento de la ganadería y la agricultura. ${ }^{23}$ Los préstamos se destinaron principalmente a obras de riego: Proyecto de riego Valle de Temascalcingo, Plan Chontalpa, Río Huiniaya y Sinaloa, El Sabino, El Rosario, El Mezquite, Las Piedras, San Lorenzo, Municipio de Tonalá, Valle de Juárez. Estas zonas de riego se establecieron en el marco del Plan Nacional de Obras de Riego para el Desarrollo Rural. Los créditos con ese fin ascendieron a más de mil millones de dólares y provenían del BID.

La segunda ventanilla del BID, Recursos del Fondo para Operaciones Especiales, está dedicada en su mayor parte al desarrollo del sector primario, al igual que la ventanilla de Recursos Ordinarios de Capital cuyos fondos se trasmiten a través del Fondo de Garantía y Fomento para la Agricultura, Ganadería y Avicultura (FIRA) y de los distintos planes y proyectos en diferentes zonas de riego.

La creación del Programa de Inversiones Públicas para el Desarrollo Rural tuvo una inversión de 1307 millones de pesos y cubrió 50 regiones del país en 30 entidades federativas. Comprende obras de infraestructura con uso preferente de mano de obra campesina, procura la creación de fuentes de empleo a través de la apertura de nuevas tierras al cultivo y el mejoramiento de las existentes, así como el establecimiento de agroindustrias y centros artesanales. ${ }^{24}$ Este programa cuenta con la participación del BID con 20.5 millones de dólares (concedidos

${ }^{23}$ El Fondo de Garantía y Fomento para la Agricultura, Ganadería y Avicultura (FIRA), dependiente del Banco de México, recibió fondos por parte del BM por 375 millones de d6́ares en 1968-1976. Cf. Varios trabajos de Ernest Feder. ${ }^{24}$ SHCP. Op. cit., p. 814. 
en 1976) y del BM con 120 millones de dólares (concedidos en 1977).

Hasta antes de 1960 la mayor parte de los créditos otorgados por el Banco Mundial eran destinados a proyectos de irrigación y a otras obras de infraestructura, como electrificación y caminos necesarios para la modernización de la agricultura considerándolo como necesario para el desarrollo de enclaves en etapas previas de agricultura capitalista exportadora.

México, uno de los favoritos del Banco Mundial, ha recibido créditos en abundancia, la mayoría para proyectos de riego y crédito agropecuario. Estos proyectos, localizados sobre todo en el norte del país, han conducido a la formación de una burguesía agraria exportadora, la cual ha contado con un apoyo sostenido del Estado que le abrió créditos, le subsidió insumos y le condonó impuestos. ${ }^{25}$

La deuda en el periodo echeverrista culminó con un monto considerable de créditos a este sector a través de varios proyectos: Programa Nacional de Inversión y Desarrollo Campesino, Fondo Nacional de Fomento Ejidal, Programa de Desarrollo Rural, Comité Coordinador de las Instituciones Nacionales de Crédito Agropecuario, Comisión Nacional Coordinadora del Sector Agropecuario, todo dentro de los lineamientos de la Comisión Nacional Coordinadora del Sector Agropecuario y del Plan Agrícola Nacional. Incluso se decretó la integración de los Bancos Ejidales, Agrícola y Agropecuario en una sola institución: el Banco Nacional de Crédito Rural.

Los créditos al campo durante el sexenio de Luis Echeverría alcanzaron un total cercano a 90 mil millones de pesos. Más del doble, a precios corrientes, que los otorgados de 1936 a $1970 .{ }^{26}$

En el periodo 1968-1976, el BM y el BID canalizaron juntos 1495.1 millones de dólares, cifra que representó el $43.2 \%$

${ }^{25}$ SELA. El FMI, el Banco Mundial y la crisis latinoamericana, Siglo XXI Editores, México, 1986, p. 15. Cf. Rama, Ruth, Fernando Rello y Gonzalo Arroyo. Investigación Económica, enero-marzo 1979, núm. 147, vol. XXXVIII, UNAM.

${ }^{26}$ SHCP. Op. cit. p. 859. 
del total de la deuda externa contratada con los organismos oficiales.

\section{Características del financiamiento al sector secundario}

En el periodo 1968-1976, el crédito de mayor monto dentro del sector secundario (casi 390 millones de dólares), se destinó al programa de expansión del sector industrial; entre los que se encuentra el Fondo de Equipamiento Industrial, dependiente del Banco de México, el cual recibió 85 millones de dólares. ${ }^{27}$ Para sintetizar, diremos que el BM destinó 640.0 millones de dólares, que equivalen al $32.8 \%$ de sus préstamos a México. El BID destinó al Fondo de Garantía y Fomento a la Industria Mediana y Pequeña (Fogain) 37.4 millones de dólares; además, participó en la construcción de la planta Siderúrgica Lázaro Cárdenas-Las Truchas (Sicartsa) así como en el programa de descentralización de la industria lechera. El BID aportó 170.0 millones de dólares, lo que representó el $16 \%$ del total de los créditos dados a México en este periodo. El Eximbank destinó, por su parte, el $45.5 \%$ de sus créditos a este sector (cuadro 8). El mayor monto se destinó a empresas del sector paraestatal como la CFE, la cual absorbió 158.1 millones de dólares; con créditos menores participaron: consorcio Minero Benito Juárez-Peña Colorada, Cementos Hidalgo, S.C.L., Productos Tubulares de Masdora, Mexicana de Papel Periódico S. A., Tereftalatos Mexicanos S. A., Kimex. S.A. e Industria Polifil S.A. El Eximbank destinó 184.2 millones de dólares, es decir, el $45.6 \%$ del total de sus créditos. La CFI - ventanilla del BM que ayuda a inversionistas industriales privados- habilitó a Minera del Norte, S. A., Celanese Mexicana, S. A., Promotora de Papel Periódico, S.A. de C. V., Cementos Veracruz, S. A., Hotel Cancún, Mexinox, S. A. En total, canalizó 40.8 millones de dólares correspondiéndole el $18 \%$ del sector secundario. Los préstamos de origen multilateral sirven para dar

${ }^{27}$ Los datos se obtuvieron de El Mercado de Valores, varios números. 
subsidios baratos a la industria tanto privada como paraestatal. Los créditos del Eximbank y de la CFI del BM permiten un engarzamiento mayor con las industrias privadas subsidiarias de las trasnacionales. Vía el equivalente general, las empresas compran bienes de capital o insumos necesarios para la reproducción del capital.

\section{Características del financiamiento al sector terciario}

Durante el periodo de estudio fue canalizado el $42.2 \%$ de los créditos para el sector terciario a través del Eximbank. ${ }^{28}$ La política de préstamos del Eximbank coincidió con el objetivo del desarrollo de las comunicaciones y transportes por parte del Estado mexicano en las décadas de los cuarenta y cincuenta. Después siguió otorgando los créditos a Ferrocarriles Nacionales de México y el monto ascendió a $84.4 \mathrm{mi}-$ llones de dólares. Se otorgaron créditos a Ferrocarriles del Pacífico, S. A. de C.V. y Constructora Nacional de Carros de Ferrocarril, S. A. por un monto de 9.9 millones. El total destinado a este sector fue de 94.3 millones de dólares. La Compañía Mexicana de Aviación recibió para compra de aviones la cantidad de 47.9 millones; Aeronaves de México, $17.9 \mathrm{mi}-$ llones. Ambas hacen un total de 65.8 millones de dólares.

El BM, a través de la Secretaría de Obras Públicas, canalizó para el mejoramiento y construcción de carreteras la cantidad de 164.3 millones; Ferrocarriles Nacionales de México 174.7 millones; Fondo Nacional de Fomento al Turismo (Fonatur) 64 millones (cuadro 8); la Secretaría de Recursos Hidráulicos 90.0 millones y la Comisión Nacional Coordinadora de Puertos, dependiente de la Secretaría de Marina, $20.0 \mathrm{mi}-$ llones. El total de los préstamos asignados por el BM al sector servicios en el periodo 1968-1976 ascendió a 471.3 millones

${ }^{28}$ Se incluye un préstamo otorgado en 1977 para el proyecto turístico en Baja California Sur por la suma de 42.0 millones, el anterior fue dado para el Centro Turístico de Ixtapa por 22.00 millones en 1982. 
de dólares. Este sector representó el $24.2 \%$ del total de sus préstamos y el $25 \%$ del total del sector terciario. ${ }^{29}$

El BID canalizó 232.9 millones de dólares al sector servicios, que representan el $22.0 \%$ del total de sus préstamos. ${ }^{30}$ En su mayoría fueron canalizados a través del Fondo para el Fomento de las Exportaciones de Productos manufacturados (Fomex) de la siguiente forma: construcción de un gasoducto en Caldas, Colombia, cuyo préstamo fue por 6.7 millones; un muelle en Puerto Limón, Costa Rica, por 1.9 millones. ${ }^{31}$ A través de Fonatur se destinaron para el desarrollo turístico de Cancún, Quintana Roo, 47.9 millones de dólares; para agua potable y alcantarillado en Nuevo León, a través del Banco Nacional de Obras y Servicios Públicos, 31.4 millones de dólares. Para equipo, construcción y mantenimiento de carreteras 116.6 millones. La suma de los préstamos asignados por el BID representa el $26.0 \%$ de los créditos destinados al sector servicios.

Financiamiento otorgado por los organismos oficiales

De los organismos financieros estudiados a lo largo del periodo 1968-1976 es necesario destacar la participación del BM y del BID en el sector primario. El primero ha destinado el $55.8 \%$ al sector primario y el BID con $16.0 \%$ y la CFI con $4.0 \%$. Nuevamente el BIRF es el mayor participante en sector de servicios con un $54 \%$, en comparación con el $26 \%$ del BID y el $20 \%$ del Eximbank (cuadro 8 ).

Es notorio, pues, que en todo el periodo el BM cobra mayor peso en todos los sectores, mientras el BID tiende a concentrarse en los sectores primario y terciario y el Eximbank en el secundario.

${ }^{29}$ Créditos contratados; se desembolsaron 513 millones de dólares.

${ }^{30}$ Créditos contratados; se desembolsaron 221.6 millones de dólares.

${ }^{31}$ El Mercado de Valores, varios números. 
El BM ha sido el organismo que, en el periodo 1968-1976, ha mantenido más peso en la deuda externa oficial de México; su participación es superior al $50 \%$ en la deuda oficial; en el segundo subperiodo con el $58.3 \%$. El BID, por su parte, participó con un $30.8 \%$ promedio durante todo el periodo. En los subperiodos correspondientes, las cifras fueron de $34.2 \%$ y $28.3 \%$ respectivamente. El Eximbank ha aumentado levemente su participación, correspondiéndole al segundo subperiodo $12.1 \%$. La participación de la AID y CFI es de poco peso y la primera no ha registrado un aporte significativo en 1973-1976.

El sector primario resulta el que tiende a captar el mayor monto de créditos con 1495.1 millones (cuadro 8). El secundario recibió 1035.0 millones y el de servicios 874 millones de dólares. Observando únicamente el periodo 1973-1976, los datos muestran lo siguiente: sector primario $1035.1 \mathrm{mi}-$ llones; sector secundario 533.9 millones; sector terciario 505.9 millones de dólares; línea que ya se presentaba entre 19681972 donde el sector primario absorbió 460 millones; el secundario 474.8 millones y servicios 368.2 millones de dólares, lo cual marca la tendencia a privilegiar el sector primario en respuesta a las políticas financieras de los organismos oficiales y de nuevos intereses dentro del proceso de acumulación a nivel internacional.

\section{Características del endeudamiento público externo contratado con organismos privados}

Al estudiar la evolución de los componentes oficiales y privados, en el periodo comprendido entre 1960 y 1967, hicimos notar cómo los préstamos privados mostraban una clara tendencia al aumento a partir de 1962 en que ambos se equilibraron con una participación del $50.0 \%$, respectivamente. Ya para el año extremo las fuentes de origen privado habían alcanzado una participación de $56.9 \%$ después de pasar por algunos momentos (1964) con mayor participación. 
De igual manera se demostró que el fenómeno no era simplemente coyuntural sino obedecía a movimientos tendenciales originados en los mercados financieros internacionales. ${ }^{32}$

Consideramos, en resumen, que la tendencia mostrada en el periodo anterior (1960-1967) se acentuó y aceleró en el periodo estudiado, especialmente a partir de 1973 . Se pueden señalar los siguientes factores externos como determinantes del creciente papel que desempeñó el financiamiento privado en la deuda pública externa:

El reciclaje de los petrodólares permitió incrementar los crecientes recursos de la banca privada, los bancos comerciales, bancos centrales nacionales, autoridades monetarias, ahorradores privados, adoptaron una política agresiva en busca de clientes de mediano desarrollo industrial para colocar créditos que por la misma recesión no pudieran ser absorbidos por los países desarrollados.

La necesidad de valorización de tales recursos llevó a la constitución de grandes centros financieros internacionales, o a revitalizarlos.

La creación del fondo del petróleo de parte del FMI, permitió a algunos países solventar problemas de balanza de pagos.

Para algunos países, las características de flexibilidad en cuanto a criterios de otorgamiento de créditos, tasas de interés que competían con las nacionales y plazos largos en su inicio, fueron atractivos para los prestatarios subdesarrollados.

Las anteriores determinantes del mercado financiero vinieron a articularse con elementos propios de la formación mexicana en el periodo de análisis:

a. Necesidad creciente de fondo para atender los gastos corrientes del Estado sin afectar sensiblemente las estructuras fiscales.

${ }^{32}$ Las características del mercado internacional de capitales, específicamente el mercado del eurodólar se tratan con toda amplitud en el capítulo 4 . 
b. La disminución relativa de la Inversión Extranjera Directa tanto por la crisis mundial como por la incertidumbre en cuanto al desarrollo financiero nacional con tal coyuntura.

c. La imposibilidad de agilizar el comercio externo de la recesión mundial y las medidas proteccionistas.

$d$. Los crecientes déficit en la cuenta corriente de la balanza de pagos.

\section{Características del endeudamiento público externo 1977-1987}

\section{Tendencias Generales}

El periodo 1977-1987 transcurrió bajo la égida del FMI y significa el tránsito de un modelo nacionalista a un modelo trasnacional; es decir, el fortalecimiento del capital financiero internacional y el debilitamiento de espacios políticos, sociales y económicos incidirán en una pérdida de soberanía nacional silenciosa.

El periodo se divide en dos partes. La etapa 1977-1982 es resultado de la tendencia del subperiodo 1973-1976 donde se hace definitiva la participación del mercado internacional de capitales, cuyo objetivo principal es la valorización del excedente a nivel internacional. Por otro lado, la política de endeudamiento está orientada a ejercer un crecimiento con base en la financiación del petróleo; en segundo lugar, la sobrevaluación del peso hizo necesaria la contratación del crédito de corto plazo para mantener un tipo de cambio barato, propiciando la fuga de capitales. Además, la deuda del sector privado creció por la necesidad de expandir sus inversiones y porque era más barato conseguir préstamos en el exterior. ${ }^{33}$ Este subperiodo coincide con el sexenio de José López Portillo.

Los años 1983-1987 se caracterizaron por la fuerte contracción en el flujo de créditos procedentes de acreedores priva-

${ }^{33}$ Con mayor precision lo hemos tratado en el capítulo segundo. 
dos. ${ }^{34} \mathrm{El}$ riesgo que presentó nuestro país para los acreedores trasnacionales originó que los créditos otorgados por este sector se emplearan principalmente para hacer frente al servicio de la deuda, y los créditos otorgados por la banca oficial multilateral servirían para una nueva reestructuración de la economía nacional. Este subperiodo coincide con otro sexenio, el del presidente Miguel de la Madrid.

\section{Variaciones absolutas y relativas de la deuda externa global}

En el cuadro 9 observamos la misma metodología de análisis que en el periodo 1968-1976 por lo que se refiere a los valores absolutos y relativos. Ello nos permite hacer el siguiente juicio:

La deuda externa pública total durante el sexenio del entonces presidente José López Portillo tuvo un incremento absoluto de 31578 millones de dólares de 1977 a 1982 . Dicho monto fue superior al nivel establecido por el sexenio anterior. Tomando 1977 como año base para el incremento del endeudamiento público, durante el periodo de su mandato, éste fue de $126.4 \%$. Sin embargo, el incremento mayor fue durante los tres últimos años. Al pasar la deuda de 38382 millones de dólares en 1980 a 56573 millones de dólares en $1982 .{ }^{35}$ Es decir, una diferencia de 18191 millones de dólares, un incremento de $32.2 \%$. Sin embargo, de 1977 a 1979 el incremento porcentual fue de 30.0 lo cual contradice las afirmaciones de algunos autores cuando indican que durante los tres últimos años hubo una mayor contratación de préstamos. Si bien este enunciado es cierto, no debe olvidarse que los tres primeros años del sexenio del presidente López Portillo estuvieron determinados por el FMI, pero también

${ }^{34}$ Los datos utilizados para este periodo provienen de las siguientes publicaciones: BID. Deuda Externa de los Paises de América Latina, Washington, D. C. julio de 1986; BID. Financiamiento Externo de los Países de América Latina (Síntesis Estadística). Washington, D. C. diciembre de 1986. Quiero hacer notar que dicha publicación fue suspendida por el propio BID.

${ }^{35}$ Los datos proceden de la publicación La deuda externa de los países de América Latina del BID y de los informes de la Secretaría de Hacienda y Crédito Público. 


\section{CUADRO 9}

DEUDA PÚBLICA EXTERNA TOTAL: PRINCIPALES COMPONENTES 1977-1987

(Millones de dólares)

\begin{tabular}{|c|c|c|c|c|c|c|c|c|c|c|c|}
\hline & 1977 & 1978 & 1979 & 1980 & 1981 & 1982 & 1983 & 1984 & 1985 & 1986 & 1987 \\
\hline re & 5 & 90 & 29 & 29 & 38 & 45 & 7 & 63197 & 64239 & 73323 & 76708 \\
\hline & & & & & & & & 4 & 30 & & \\
\hline Créc & 627 & 21673 & 26412 & 27535 & 33588 & 39 & 56492 & 58682 & 59683 & & \\
\hline P & 5 & 464 & 338 & 266 & 302 & & 6 & 436 & 476 & & \\
\hline cre & 4450 & 542 & 5826 & 7453 & 9021 & 11336 & 11613 & 10994 & 12385 & 12285 & 14835 \\
\hline & 3145 & 3761 & 4424 & 5230 & 6310 & 7663 & & 7570 & 8930 & & \\
\hline Bilaterales & 13 & 1668 & 1402 & 2223 & 27 & 3673 & & 3424 & 3455 & & \\
\hline TOTAL & 24995 & 30719 & 35727 & 38382 & 47396 & 56573 & 73370 & 74191 & 76624 & 85608 & 91543 \\
\hline
\end{tabular}

FUENTE: BID. Deuda externa de los paises de América Latina. Departamento de Desarrollo Económico y Social, Washington, 1987. 
por las disposiciones de la banca trasnacional para financiar la plataforma petrolera de exportación.

Al tomar en cuenta el comportamiento de la deuda externa global se concluye que el monto total se triplicó, si consideramos que 1976 finalizó con un nivel de 18282 millones de dólares. Es menester recordar que el presidente tomó posesión el 1 de diciembre de ese año. Seis años después el nivel de endeudamiento alcanzó 56573 millones de dólares.

Al observar el endeudamiento del subperiodo 1983-1987, para analizar el crecimiento de la deuda pública externa durante los primeros cinco años del gobierno de Miguel de la Madrid, se tiene que 1982 terminó con una deuda de 56573 y a finales de 1987, ésta ascendió a 91543 millones de dólares; no debemos olvidar que el actual sexenio absorbió la deuda de los bancos nacionalizados y parte de la deuda de la industria privada. Es decir, la deuda externa tuvo un incremento absoluto de aproximadamente 34970 millones de dólares, lo cual hace un incremento de $62 \%$ y representa un crecimiento modesto al compararse con el sexenio lópezportillista donde, porcentualmente, la deuda externa pública total se triplicó y en el sexenio echeverrista se cuadruplicó. Sin embargo, el aumento absoluto de 34970 millones de dólares es abominable en este periodo a la luz del pago del servicio de la deuda externa.

El promedio anual de crecimiento de la deuda externa pública fue de 17.92 durante 1977-1982; en 1982-1987 de $9.53 \%$ y en 1977-1982 fue de $13.75 \%$. Esto indica que la contratación de créditos disminuyó en el segundo subperiodo a cerca de la mitad del primer subperiodo, porque la meta de la política de endeudamiento fue dar alternativas y soluciones al problema del pago de la deuda externa. No así al crecimiento del país.

Componentes oficiales y privados de la deuda externa total

La tendencia a contratar préstamos con los acreedores privados persiste al igual que el periodo anterior: 1968-1976 
(cuadro 9). El promedio de la deuda contratada con dichos organismos es de $82.4 \%$. En tanto, el promedio de la deuda contratada con los acreedores oficiales es de $17 \%$. Dicho porcentaje varía en algunos años. Es interesante observar que en el subperiodo 1983-1987 los acreedores privados no disminuyen su participación en forma importante dentro del total, a pesar de la crisis de liquidez que presenta México en 1982. Ello es congruente con su política a nivel mundial y con nuestro planteamiento teórico de observar la participación que tiene el equivalente general y el capital en una economía interdependiente del proceso de acumulación internacional.

Los préstamos contratados con la banca trasnacional tienen un gran peso dentro del total de la deuda pública externa antes y después de 1982, sean estos para la renegociación de la deuda o para uso de las inversiones públicas. La necesidad de recibir créditos frescos se hizo presente en el terremoto de 1985, así como durante el último semestre de 1986 ante la drástica disminución de divisas por concepto de exportaciones petroleras.

\section{La deuda oficial según tipo de organismo prestatario}

Durante el periodo 1977-1985 el promedio porcentual de la deuda contratada con los organismos oficiales fue de alrededor del $20 \%$ dentro del total de la deuda global del sector público. ${ }^{36}$ De esa cantidad se obtuvo un promedio de $70 \%$ de la deuda contratada con los organismos multilaterales. La deuda contratada con los organismos fue en promedio 30.0 por ciento.

No obstante, el incremento del componente bilateral fue mayor al multilateral. Tenemos, pues, que si tomamos como referencia 1977 igual a 100 resulta que en un periodo de ocho años los préstamos con organismos bilaterales tuvieron

${ }^{36}$ La publicación del BID Deuda Externa de los Paises de América Latina de diciembre de 1987 contiene datos hasta 1985. Posteriormente, las publicaciones del BID se basaron en los datos del BM. 
un crecimiento de $162.3 \%$ y los multilaterales de $140.7 \%$. El único año que el crecimiento es menor, es 1979 (cuadro 9).

Importa destacar que a pesar del aumento relativo de la deuda contratada con organismos multilaterales y bilaterales, hay años en que la tasa anual es negativa. Ejemplo de ello es 1984 cuando los organismos multilaterales tienen un decremento de $3.1 \%$ y el aumento en relación a 1982 fue de $1.9 \%$ en 1983. Los organismos bilaterales tuvieron un decremento de $12.8 \%$ y $11.1 \%$ en 1979 y 1984 respectivamente (cuadro 9).

El decremento de los organismos bilaterales, entre ellos el Eximbank, redujo su tamaño por las exigencias del presupuesto estadounidense y porque los exportadores enfrentaban severas contracciones ante la crisis de deuda. Incluso la CFI, otorgante de préstamos directos a los industriales, ha optado por incrementar sus préstamos en países desarrollados y no en países de alto riesgo como México.

Canalización de préstamos de origen oficial durante 1977-1986

Las instituciones financieras internacionales como el BM y el BID canalizaron durante el periodo 1977-1986 la cantidad de 8077.5 millones de dólares (cuadro 9), mismos que se orientaron en su mayor parte al sector primario; estos préstamos representaron cerca del $41 \%$. Al sector secundario se canalizó el $28 \%$ y al sector servicios se le confirió el restante 31 por ciento.

El BM otorgó 6043 millones de dólares. El 38\% lo canalizó al sector primario, el $32 \%$ al sector secundario y el $30 \%$ al sector terciario. Dentro del sector secundario el banco participó con el $87 \%$. En el sector primario y de servicios el banco aportó el $70 \%$ del total (cuadro 10).

El BID concedió durante el periodo señalado la cantidad de 2034.5 millones de dólares. La mayor parte la destinó a la agricultura; es decir, la mitad de su financiamiento se condujo al sector primario. El $36 \%$ lo destinó al sector servicios y el $14 \%$ al sector secundario. 
CUADRO 10

CANALIZACIÓN DEL CRÉDITO OFICIAL

POR SECTORES: 1977-1986

(Millones de dólares)

\begin{tabular}{lrrrr}
\hline Sectores & Primario & Secundario & Terciario & Total \\
\hline Banco Mundial & 2315.5 & 1941.3 & 1786.3 & 6043.0 \\
BID & 999.5 & 288.0 & 749.0 & 2034.5 \\
TOTAL & 3314.9 & 2229.3 & 2533.3 & 8077.5 \\
\hline
\end{tabular}

FUENTE: Nacional Financiera, El Mercado de Valores (varios números) y datos proporcionados por la Secretaría de Hacienda y Crédito Público, División de Organismos Financieros Internacionales. Cuadro elaborado por la autora.

La tendencia predominante en este periodo es que el sector primario sigue siendo prioritario en el financiamiento otorgado por las instituciones internacionales de carácter multilateral. Es el sector servicios, con el $31 \%$, el que ocupa el segundo lugar, en tanto el sector secundario recibe el 28 por ciento.

En el sector servicios es importante destacar que el turismo ha recibido bastante financiamiento a través de la creación de los fideicomisos Fonatur y Fonei, con el objeto de allegarse recursos. No obstante, como hemos señalado, este tipo de obras de infraestructura facilitan a las inversiones extranjeras directas la ampliación de sus cadenas internacionales. La reconstrucción de viviendas es un rubro que cobró importancia por el terremoto de 1985. El BM aportó 571.4 millones de dólares por dicho concepto.

La modernización de los ferrocarriles es objeto prioritario en la renovación de las vías de comunicación y también han recibido un fuerte apoyo.

En el sector primario cabe mencionar que uno de los proyectos importantes es el relacionado al Programa de Desarrollo Integral del Trópico Húmedo, el cual responde a una estrategia internacional. ${ }^{37}$ Dicho proyecto tiene un costo to37 " El Banco Mundial y la Asociación Internacional de Fomento siguen siendo la fuente principal de recursos externos para el desarrollo agrícola en los trópi- 
tal de 217.5 millones de dólares y servirá para la producción de cultivos y ganadería.

Otro proyecto, administrado por el fideicomiso del Banco de México, es FIRA con objeto de elevar la productividad de alimentos y exportaciones agrícolas; tiene un costo de 473 millones de dólares.

La sobreprotección que el gobierno mexicano mantuvo (en palabras del BM) a su industria hasta antes de 1982 no permitió que México pudiese competir en otros productos que no fueran los petroleros, lo cual coincidió en uno de los elementos necesarios de política económica para 1983-1988. El gobierno mexicano junto con los intereses del BM y con el objeto de allegarse divisas puso en operación el Programa de Financiamiento de Divisas para la exportación, (Profide). Además, México condicionó el Proyecto a los intereses del BM. Según

ese organismo, el propósito central del Proyecto es doble: a) cooperar con el gobierno de México en la formulación e instrumentación de una estrategia integral de fomento a las exportaciones y b) en un periodo crítico de escasez de divisas, otorgárselas a los exportadores mexicanos a un costo "razonable" para que puedan importar los insumos de producción necesarios para fabricar bienes exportables. ${ }^{38}$

cos. En los ejercicios 1974-84, el Banco aporto las dos terceras partes de la ayuda multilateral y casi una tercera parte de toda la asistencia oficial para el desarrollo. El Banco invirtió cerca de 33 mil millones en proyectos agrícolas que ocasionaron una inversión total de entre 90 mil y 100 mil millones en 1974-1984. El mayor prestatario fue la India, que recibió del Banco 4500 millones, seguido de México, 2500 millones de dólares, Indonesia (2 000 millones), Brasil (1 300 millones), Rumania y Yugoslavia (mil millones). Puede parecer coincidencia, pero los resultados de la agricultura en estos prestatarios fueron razonablemente fructíferos". Cf. Montgue Yudelman "El crédito agrícola del Banco, 1974-1984", en Finanzas y Desarrollo, núm. 4, diciembre de 1984, volumen 21.

38 " "En el informe que el Banco Mundial presentó a los directores ejecutivos de esa organización recomendó la aprobación del préstamo destinado al Proyecto de Fomento a las Exportaciones de México. Sobresale la preocupación (tal vez como reflejo de la comunidad internacional acreedora) por conocer, diseñar revisar o influir en la estrategia y en las decisiones del gobierno mexicano al orientar su política comercial externa, especialmente en las promociones de exportaciones no petroleras y en la reducción tradicional proteccionista indiscriminada a favor de la sustitución de importaciones"'. Cf. Alvarez Uriarte, Miguel. Financiamiento al Comercio Exterior, El Colegio de México, 1985, p. 88. 
Comportamiento global del endeudamiento público externo con organismos privados 1977-1986

En el capítulo correspondiente al desarrollo de las características del endeudamiento externo en el periodo 1968-1976 habíamos hecho referencia a la contratación de los organismos privados y su participación en el total de la deuda externa, con el objeto de demostrar la tendencia cuantitativa de la participación mayoritaria de los préstamos otorgados por los organismos privados, tendencia que durante 1968-1976 fue definitiva para el periodo 1977-1987.

El subperiodo de 1977-1982 se caracterizó por la creciente contratación de endeudamiento del sector público con el mercado de capitales, específicamente el euromercado, siendo las empresas: Pemex, Nacional Financiera, CFE y el gobierno federal los prestatarios de mayor renombre por catalogarse como buenos deudores solventes. El segundo subperiodo 1983-1988 planteará la respuesta adecuada a la crisis del crecimiento de los créditos. Al encabezar México la crisis financiera y volverse un país de alto riesgo, el crédito contratado con la banca trasnacional es moderado, pero servirá como divisa para el pago de la deuda externa. Ante ello, es necesario nombrar a la deuda anterior como deuda vieja y a la necesidad de nuevos créditos frescos se le llamará deuda nueva. Ello estaría relacionado con nuestra hipótesis teórica de la necesidad del capital en la financiación de la reproducción de capital y de la no interrupción del ciclo del capital.

A pesar de la disminución de los créditos de los organismos privados, durante los últimos cuatro años del periodo de estudio, en ningún momento se ve alterada la tendencia hegemonizante de los organismos privados sobre el contexto de la deuda externa total. 
Componentes globales del endeudamiento público contratado con organismos privados 1977-1986

Los componentes que engloban los organismos privados están desglosados en proveedores, bancos, bonos y nacionalizaciones (cuadro 9$)^{39}$ y no representa en nuestro país ninguna cantidad que pudiera alterar el total de lo contratado con los organismos privados. Por ello, sólo analizaremos los tres elementos enunciados al principio.

El rubro bancos representó el $85.7 \%$ del total de organismos privados durante 1977. Sin embargo, este porcentaje sube en 1984 a $92.8 \%$ (cuadro 9).

En tanto que los préstamos otorgados por proveedores, disminuyeron drásticamente. Estos representaban el 2.8\% durante 1977 y disminuyeron a $0.8 \%$ para 1984; es decir, disminuyeron más de tres veces. La disminución se explica por la falta de disponibilidad de algunos comerciantes, a nivel internacional, para otorgar préstamos y adquirir sus productos dado que a través de los créditos contratados en el mercado internacional de capitales había menores posibilidades de riesgo.

Variaciones absolutas y relativas del crecimiento 1977-1987

La deuda pública contratada con los organismos privados alcanzó un monto de 20545 millones de dólares durante 1977. Esta ascendió a 76708 millones de dólares durante 1987. Tomando como base el año 1977, el crecimiento fue de $373.4 \%$ hacia 1987; es decir, se duplicó (cuadro 15). El crecimiento absoluto de dicho componente fue mayor al de la deuda externa total. De 1977 a 1987 el incremento fue de $373.4 \%$ y de 1977 a 1982 fue de $220.2 \%$. A partir de 1983 los créditos contratados con los bancos privados no son para el crecimiento. El periodo 1983-1987 es esencialmente de refinanciamiento.

39 BID. La Deuda Externa de los Países de América Latina, Washington, D. C., julio de 1986. 
En relación con las tasas anuales de la deuda externa contratada con los organismos privados podemos afirmar que son crecientes en los dos primeros años del gobierno del licenciado López Portillo. Sin embargo, el ritmo de crecimiento anual disminuye en 1980 al ser éste del $3.4 \%$. En los tres años siguientes el crecimiento anual fue mayor según la explicación del capítulo 2, dada la política de endeudamiento de corto plazo que se sigue en 1981, año en que la tasa de crecimiento fue del $24 \%$. En 1982 disminuye la tasa anual a 17.9 a causa de la incertidumbre que plantea la crisis de liquidez. No obstante, 1983 muestra un crecimiento de $36.5 \%$, e indica la cantidad de préstamos de salvamento para el país en ese año y el crédito fresco. En 1984 y 1985 la tasa anual fue de $2.3 \%$ siendo éstas las tasas menores de todo el periodo 1977-1987. 


\section{TRASNAGIONALIZACIÓN DE LA DEUDA EXTERNA}

El equivalente general ingresa a la economía vía el Estado desde mediados de la década de los sesenta. El componente bancario de la deuda externa pública, al menos en México, toma primacía sobre el componente oficial. Y es en esta medida que dicho componente a través del Estado empieza a controlar la economía nacional. ¿Cómo surge el proceso de trasnacionalización vía el equivalente general en la economía nacional? ¿Cómo es que podemos mencionar la trasnacionalización abierta de la economía mexicana? El presente capítulo observa la trasnacionalización del endeudamiento del gobierno federal y del petróleo mexicano, Pemex.

\section{Proceso del endeudamiento externo}

La deuda externa del sector público de los países subdesarrollados presentó modificaciones cualitativas y cuantitativas en sus componentes durante la década de los setenta. Dichas modificaciones se caracterizan porque se ha pasado a depender de fuentes de origen privado o trasnacional; se denomina trasnacionalización de la deuda porque son bancos pertenecientes a conglomerados trasnacionales los que otorgan los créditos. ${ }^{1}$ Su crecimiento a tasas casi exponenciales tiene una explicación lógica y teórica en el marco de la crisis mundial capitalista.

${ }^{1}$ En el capítulo 3 analizamos de manera empírica la estructura de la deuda externa pública. Allí se demostró cómo a partir de mediados de la década de los sesenta los acreedores privados empiezan a tener mayor peso que los organismos financieros internacionales. 
El endeudamiento del sector público de los países subdesarrollados alcanzó una suma sin precedentes, $634100 \mathrm{mi}-$ llones de dólares en 1980 y un billón 280000 millones de dólares en $1989 .^{2}$ En su mayoría, dicha deuda está contratada con bancos trasnacionales; para ser más precisos 12 grandes bancos cuyo objetivo es obtener un rendimiento alto y a corto plazo. Aunque la cifra pone en riesgo la liquidez del sistema financiero internacional, significa que si el financiamiento se ha de entender como un esfuerzo por el progreso de los países en desarrollo, se seguirá necesitando del refinanciamiento de las deudas que se vencen. En los mercados de capital esto se ha interpretado en el sentido de que "los ajustes bancarios que han permitido aumentar los créditos financieros a los países en desarrollo deberán seguir siendo suficientemente flexibles para que, a su vez, permitan ajustes monetarios; es decir, devaluaciones periódicas y renegociaciones anuales o bianuales". ${ }^{3}$ Lo anterior coincide con los criterios de los organismos financieros oficiales como el Banco Mundial (BM), el Fondo Monetario Internacional (FMI) y el mismo Banco Interamericano de Desarrollo (BID) quienes reconocen que tanto el financiamiento externo como las inversiones directas han ampliado

el desarrollo industrial y la construcción de la infraestructura necesaria, en especial en transportes, comunicaciones y energía [aunque] el proceso de desarrollo en la mayoría de los países ha exhibido una naturaleza desigual, no sólo entre las diversas regiones que componen los países, sino también entre los distintos grupos que integran cada sociedad. ${ }^{4}$

${ }^{2}$ FMI. World Economic Outlook. Washington D. C., octubre de 1988, p. 123.

${ }^{3}$ Klein, Thomas. "La situación de la deuda externa en los países en desarrollo', en Finanzas y Desarrollo, vol. 13, núm. 4, diciembre de 1976, p. 25. La tasa para préstamos internacionales de instituciones financieras privadas es la London Interbank Offer Rate (Libor). Su margen ha variado desde un $0.5 \%$ hasta un $11.2 \%$.

${ }^{4}$ BID. Reunión Extraordinaria de la Asamblea de Gobernadores. Washington, D. C., diciembre de 1978, p. 4. 
Por tanto, la necesidad de seguir con un tipo de desarrollo capitalista hace necesario el financiamento externo, a pesar de las contradicciones implícitas en él.

El incremento del endeudamiento externo y sus implicaciones son evidentes a partir de las pruebas empíricas. Según las tablas del FMI, a finales de 1989 el $80 \%$ de la deuda de los países subdesarrollados se contrató con instituciones financieras privadas; es decir, bancos trasnacionales. El resto estuvo contratado con organismos financieros internacionales como el BM y los bancos regionales. En 1980, el $48 \%$ correspondió a organismos financieros y el $52 \%$ a bancos trasnacionales. Sin embargo, tan sólo unos cuantos años antes, en 1973, la deuda contratada de los países del Tercer Mundo ascendía a 119533 millones de dólares; 78619 millones contratados con instituciones oficiales y 40933.8 millones con bancos trasnacionales; es decir, porcentualmente, ambas cifras representaban 65.7 y $34.3 \%$ respectivamente. ${ }^{5}$ De lo anterior deducimos que la tendencia de la deuda externa de dichos países ha sido a contratarse cada vez más y en ritmos crecientes, con bancos trasnacionales, pues el incremento de dichos préstamos entre 1973 y 1980 fue de $500 \%$. El incremento entre 1980 y 1987 fue de $510 \%$ lo que muestra la tendencia a la trasnacionalización de la economía internacional en el ambiente financiero, a pesar de la disminución de los préstamos de origen trasnacional por las casas matrices, dado el creciente riesgo que representan los países del Tercer Mundo por la crisis de liquidez cuyo inicio se sitúa en $1982 .{ }^{6}$ Para 1989 el $46 \%$ estaba contratado con la banca trasnacional y el resto con organismos financieros.

Por otro lado, es importante mencionar cómo el servicio de la deuda también ha crecido, pues llegaba a un monto de 101.8 mil millones de dólares anuales en 1980. Al sumar el servicio de los países del Tercer Mundo a los acreedores de

\footnotetext{
${ }^{5}$ World Bank. World Debt Tables, EC-167/80.

${ }^{6}$ FMI. World Economic Outlook, Washingtón, D. C., octubre de 1989.
} 
1980 a 1989 se obtiene una cifra de un billón 282600 millones de dólares. ${ }^{7}$

Antes de pasar al caso particular de América Latina, haremos un bosquejo de los principales deudores del Tercer Mundo en 1980. Brasil, México y España ocuparon el primero, segundo y tercer lugares entre los países con un mayor monto de créditos; siguiendo India, Argelia, Indonesia, República de Corea, Yugoslavia, Argentina, Israel, Turquía, Egipto, Venezuela, Paquistán y Grecia. Llama la atención que los principales deudores de bancos trasnacionales se encuentran en América Latina: Brasil, México, Argentina y Venezuela, excepto España, Yugoslavia y Corea. En cambio, los principales acreedores de las instituciones oficiales se encuentran en Asia y el Medio Oriente: India, Egipto, Indonesia, Paquistán, Turquía e Israel. Esto refleja, por un lado, las necesidades de rentabilidad de los bancos privados y, por otro, la urgente necesidad de ciertos países subdesarrollados de realizar obras de infraestructura que amplíen el desarrollo de tipo capitalista. Los últimos países sujetan su política económica a los lineamientos de orden internacional del BM, FMI, Agencia Internacional de Desarrollo (AID), etc. controlados por Estados Unidos, donde el apoyo de la ayuda oficial refuerza el control de zonas estratégicas para su política exterior.

Al ocuparnos de América Latina, los informes del FMI indican lo siguiente: el monto de la deuda externa fue de 231100 millones de dólares en 1980; es decir, representa el $36.5 \%$ de la deuda externa de los países subdesarrollados. El $18 \%$ estaba contratado con organismos oficiales y el $72 \%$ se contrató con bancos trasnacionales. Según las estimaciones del FMI, dicha deuda llegó a 433300 millones de dólares en 1988. El $24 \%$ correspondió a créditos otorgados por las instituciones financieras oficiales y el $76 \%$ a la banca privada trasnacional. A pesar de una ligera disminución de la participación de los bancos privados, por el riesgo que implica prestar a dichos países y a un incremento de una mayor participación de 
los organismos financieros internacionales, no quiere decir que la trasnacionalización vaya a disminuir a largo plazo. No olvidemos que América Latina se convirtió en la gallina de los huevos de oro con las múltiples renegociaciones de su deuda y que por ello es una zona tributaria de capital por lo que necesita de nuevos préstamos, a pesar de la negativa de los bancos a seguir prestando. Aldo Ferrer decía al respecto:

cuando estalló la crisis de la deuda externa latinoamericana en 1982, los bancos privados latinoamericanos tomaron dos decisiones principales: cobrar todo lo posible y reducir su riesgo en América Latina. El éxito de esta estrategia ha sido extraordinario. Desde aquél año hasta ahora los acreedores obtuvieron de sus deudores latinoamericanos 150 mil millones de dólares. En el mismo periodo, la deuda aumentó 100 mil millones de dólares como consecuencia del hecho inevitable de que, a pesar de la dimensión del esfuerzo y del ajuste América Latina, no llegó a pagar la totalidad de los intereses devengados. ${ }^{8}$

El BID confirma lo anterior al mostrar cómo el coeficiente intereses-servicio de la deuda, que en 1970-1974 era del $31.2 \%$, aumentó del $51.4 \%$ en 1981 al $63.2 \%$ en 1983 y al $69.6 \%$ en 1984 . En cifras absolutas, el monto de los pagos de intereses aumentó del $51.4 \%$ en 1981 al $63.2 \%$ en 1983 y al $69.6 \%$ en 1984 . El $85 \%$ de esas cantidades afluyó a los mercados financieros privados. Como los pagos de intereses fueron cuantiosos, se invirtió radicalmente la tendencia de las transferencias netas de recursos externos de la región. ${ }^{9}$

Antes de concluir sobre la problemática del endeudamiento en América Latina, creemos conveniente señalar que son aquellos países con estabilidad política, aunada a la garantía estatal, gran desarrollo industrial y la participación del capital monopolista, los que presentan una estructura de sus deudas del sector público, dependiente del capital financiero trasnacional. No así el caso de los países de Centroamérica,

${ }^{8}$ Ferrer, Aldo. "Acumulación, cambio tecnológico y deuda externa', en Comercio Exterior, vol. 37, núm. 12, México, diciembre de 1987, p. 1050.

${ }^{9}$ BID. Deuda externa de los países de América Latina. Departamento de Desarrollo Económico y Social. Washington, D. C., julio de 1986, p. 7. 
donde la debilidad de las burguesías industriales nacionales, ha impedido un crecimiento capitalista en beneficio de una clase intermedia; las estrecheces de los mercados internos y el continuo avance de las luchas sociales debilitan al Estado $y$, por tanto, no lo hacen sujeto ni de garantía, ni de rentabilidad a los bancos privados. Por ello estos países dependen de las instituciones oficiales multilaterales y bilaterales, como la AID, que han participado en la ayuda económica y ayuda militar de gobiernos impuestos por intereses estadounidenses. Es aquí donde la deuda pública externa se convierte de fenómeno económico en instrumento político. ${ }^{10}$

\section{El mercado del eurodólar}

El mercado del eurodólar -entendido genéricamente para incluir todos los mercados externos de las principales monedas convertibles - es decir, una innovación financiera internacional iniciada en los años 1958-1959 “... se desarrolló y continúa haciéndolo sin privilegios oficiales, subsidios, ni ventajas tributarias [..], tan amplio, tan irracional y tan competitivo, que ningún país puede controlarlo y ni siquiera influir mucho en él" ". Esto necesariamente produjo efectos en los mercados financieros internacionales, en el origen del financiamiento de las diferentes formaciones sociales de los países capitalistas avanzados y, en menor grado, pero no por ello insignificantes - como lo muestran los datos que analizaremos-, especialmente en los países subdesarrollados, como México, con grandes atractivos en la coyuntura petrolera.

Las tasas de interés en el mercado de eurodólares, en su mayoría, fueron menores a las nacionales. Los créditos allí obtenidos son flexibles en cuanto al destino, incluyendo financiamiento de los déficit en la balanza de pagos y extendiendo su campo de acción a bancos, empresas y gobiernos.

${ }^{10}$ Girón, Alicia. "Deuda externa, instrumento político: El Salvador", en Problemas del Desarrollo, IIEc-UNAM, núm. 43.

${ }^{11}$ Altman, Oscar L. "Eurodólares", en Finanzas y Desarrollo, marzo de 1967, vol. IV, núm. 1, p. 12. 
El mercado del eurodólar se vio reforzado en los años setenta con fondos líquidos provenientes de los países petroleros, y ha ejercido una influencia determinante en la composición de la deuda pública externa de los distintos países.

El mercado del eurodólar no ha tenido similar comportamiento en todas las épocas ni en los montos aportados a los diferentes países. En cuanto a los subdesarrollados, su acceso fue restringido históricamente y sólo cobró importancia en los años setenta, concentrándose en un reducido número de países considerados de "altos o medianos ingresos" como sería el caso de México y Brasil.

Algunos estudios como el del Comité de Desarrollo del BM y del FMI, integrado en junio de 1975, llegaba a las siguientes conclusiones:

Es bien sabido que los países menos desarrollados han podido aprovechar el mercado de eurocréditos de manera sustancial en los últimos años. No obstante, reconocer la importancia y el valioso papel de los bancos durante el reciente periodo de acentuadas dificultades de balanza de pagos, autoridades monetarias nacionales han estado poniendo cada vez más en duda lo acertado de la intervención permanente y a gran escala de los bancos comerciales en financiamiento directo de las balanzas de pagos. ${ }^{12}$

El mismo informe muestra la relativa "exclusión" de los países menos desarrollados, ante el "aumento de la demanda de los países industriales", además de lo modesto de tal participación, especialmente por prácticas y reglamentaciones que limitan su acceso. ${ }^{13}$ Se trata, entonces, de un fenómeno congruente con la necesidad del capital monopolista internacional en los países donde se asegura una rentabilidad atrayente. Por ello, serán países como Brasil, Argentina y México donde el conglomerado trasnacional asegura sobre las clases sociales el proceso de acumulación interno y su re-

${ }^{12}$ Ibid.

${ }^{13}$ Kapur, Ishan. "Fondos en eurodivisas para los países en desarrollo, en Finanzas y Desarrollo, vol. 14, núm. 3. 
producción dentro del contexto mundial, así como la obtención de una ganancia rentable.

Conviene incluir un cuadro sobre el destino por países, concretado en los eurocréditos que en parte han determinado la nueva orientación de las fuentes de financiamiento privado, como un marco de referencia en nuestro análisis. El cuadro 11 muestra un comportamiento irregular y una sensible orientación creciente en 1975 y 1980 . Después permanece estable durante 1982 y 1983 pero se recupera en 1984.

Otras estimaciones factibles, a nuestro juicio, ya que el cuadro anterior recoge sólo algunos créditos publicados, hacen ascender la cifra a países en desarrollo a 203006 millones de dólares en 1980 a 440.9 mil millones de dólares en 1987.

Retrocediendo en perspectiva al año 1975, cuando el total fue de 22800 millones y ascendió a 38300 millones de dólares en 1979, el crecimiento relativo en dicho periodo fue de $231 \%$; es decir, una tasa anual de $38.5 \%$. En los años 1980-1987 el crecimiento relativo fue de $116.9 \%$; es decir, una tasa anual de $16.7 \%$. Es impresionante la disminución del ritmo en que venían contratando los países subdesarrollados en el mercado de eurocréditos hasta antes del inicio de la década de los ochenta, por la necesidad de valorizar el capital a nivel internacional, resultado del excedente petrolero. Se presenta al inicio de los años ochenta su contraparte: la baja de los precios internacionales del petróleo reduce el capital a nivel internacional junto con el inusitado aumento de las tasas de interés que provocaron de inmediato el encarecimiento del servicio de la deuda de dichos países.

Es importante destacar que América Latina participó como receptor con más del $58 \%$ del total de los préstamos otorgados en el mercado de euromonedas, incluso llegó al $50 \%$ durante 1984 (cuadro 12).

Habría que resaltar en este tipo de préstamos el tipo de interés promedio al que se contrataron los préstamos del mercado eurodólar. En 1981 fueron del 16.7\%; en 1982 del $13.6 \%$; en 1983 del $9.9 \%$; en 1984 del $11.3 \%$; en 1985 del $8.6 \%$ y en 1986 del $7.1 \%$. De ahí que el interés muy alto 


\section{CUADRO 11}

EMISIONES Y COLOCACIONES DE BONOS INTERNACIONALES 1965-1987

(Miles de millones de dólares)

\begin{tabular}{l|c|c|c|c|c|c|c|c|c|c|c}
\hline & 1965 & 1970 & 1975 & 1980 & 1981 & 1982 & 1983 & 1984 & 1985 & 1986 & 1987 \\
\hline Mercado de Eurobonos & 0.9 & 3.5 & 10.5 & 20.4 & 31.3 & 50.3 & 50.1 & 81.7 & 135.4 & 161.0 & 172.7 \\
$\begin{array}{l}\text { Mercado de Bonos } \\
\text { Extranjeros }\end{array}$ & 2.4 & 2.4 & 12.3 & 17.9 & 20.5 & 25.2 & 27.1 & 27.8 & 31.0 & 47.9 & 24.3 \\
$\begin{array}{l}\text { Total de Bonos } \\
\text { Internacionales }\end{array}$ & 3.3 & 5.9 & 22.8 & 28.3 & 51.8 & 75.5 & 77.2 & 109.5 & 166.4 & 208.9 & 197.0 \\
\hline
\end{tabular}

FUENTE: Banco Mundial. Informe sobre el Desarrollo Mundial. 1985, Washington, 1985 p. 142 ; FMI. Financial Stadistics (varios números). 


\section{CUADRO 12}

PRÉSTAMOS DE CONSORCIOS EN EUROMONEDAS A PAÍSES EN DESARROLLO POR REGIONES 1972-1984 (Miles de millones de dólares)

\begin{tabular}{lrrrrr}
\hline \multicolumn{1}{c}{ Región } & 1972 & 1976 & 1980 & 1982 & 1984 \\
\hline Asia Oriental y el Pacífico & 0.4 & 2.9 & 8.8 & 10.3 & 7.4 \\
Porcentaje del Total & 11.0 & 20.0 & 24.0 & 27.0 & 33.0 \\
Europa y el Mediterráneo & 0.6 & 0.6 & 3.9 & 3.2 & 2.2 \\
Porcentaje del Total & 16.0 & 4.0 & 11.0 & 8.0 & 10.0 \\
América Latina y el Caribe & 2.0 & 8.7 & 19.9 & 22.2 & 11.4 \\
Porcentaje del Total & 53.0 & 60.0 & 55.0 & 58.0 & 50.0 \\
Otras regiones $^{a}$ & 0.8 & 2.4 & 3.6 & 2.6 & 1.7 \\
Porcentaje del Total & 20.0 & 16.0 & 10.0 & 7.0 & 7.0 \\
TOTAL & 3.8 & 14.6 & 36.2 & 38.3 & 22.7 \\
Por ciento & 100.0 & 100.0 & 100.0 & 100.0 & 100.0 \\
\hline
\end{tabular}

a Incluye a África al sur del Sahara, China, India, el Oriente Medio, el Norte de África y Asia Meridional.

FUENTE: OCDE. Financial Market Trends. Banco Mundial, Informe sobre el Desarrollo Mundial 1985 , p. 138.

al inicio de los años ochenta provocó problemas al enfrentarse con una deuda bastante cara. La tasa de interés del mercado del eurodólar fue menor al promedio de la Prime Rate. ${ }^{14}$

\section{México en el mercado de eurocréditos}

La etapa de 1973 a 1982 estará caracterizada por el monto creciente de los créditos contratados por el país para el financiamiento de la reproducción de capital. Las bajas tasas de interés y un plazo de pagos razonable, acaecidos en circunstancias y condiciones favorables a los deudores, durante los años setenta, propician un ambiente de corresponsabilidad. $\mathrm{El}$ interés de la banca internacional por valorizar y reciclar los excedentes petroleros permitió a países de cierto desarro${ }^{14}$ OCDE. Financial Markets Trends (varios números). 
llo medio ser los principales clientes cautivos de la banca trasnacional.

Haremos una reseña del periodo 1973-1982 resaltando quiénes fueron los acreedores en el mercado internacional y las empresas prestatarias mexicanas. Señalaremos asimismo la canalización de los préstamos contratados por el sector público, articulando la hipótesis central de nuestra investigación para mostrar la integración entre el proceso de acumulación interno y el proceso de acumulación externo.

Conviene señalar que

la constante participación del prestatario público mexicano en el euromercado determinó que la contraparte acreedora de nuestra deuda externa se encontrara representada, en la mayor parte de los créditos unitarios, por instituciones privadas, articuladas al mercado financiero internacional. Con lo anterior, la determinación de las condiciones de los préstamos se estableció de acuerdo a las leyes de la oferta y la demanda en donde las voluntades de los acreedores y de los deudores, visualizados de manera individual, no son capaces de influir en el establecimiento del costo del crédito. ${ }^{15}$

Para nuestro estudio fue importante apuntar el total de las operaciones desarrolladas por el prestatario público mexicano. Se tomaron en cuenta las operaciones llevadas a cabo en el mercado de eurodólares, sin hacer hincapié entre la diferenciación de los euro-créditos y las euro-obligaciones. ${ }^{16}$

Durante el periodo 1973-1982 tanto el sector público como el sector privado contrataron la cantidad de 48717 millones de dólares, de los cuales le correspondió al sector público

${ }^{15}$ Malagón Vera, Alfonso. La administración de la deuda pública externa. Contribución al estudio de la crisis de la deuda. Premio de Administración Pública 1985. Instituto Nacional de Administración Pública A. C., México, 1987.

${ }_{16} \mathrm{Ibid}$. "Al interior del mercado de eurocapitales se destacan dos tipos de operaciones: las euro-obligaciones y los eurocréditos". Los eurocréditos son operaciones de crédito a mediano plazo; es un préstamo bancario con recursos obtenidos en el mercado de eurodivisas, asimismo son préstamos donde existe la sindicalización. Las euro-obligaciones tienen las mismas características que los créditos pero éstos son títulos negociables, lo cual implica su posible negociación en una Bolsa de Valores. (véase p. 25 y p. 73, respectivamente). 
41925 millones de dólares y al sector privado 7262 millones de dólares; es decir, el $86 \%$ y el $14 \%$, respectivamente. Las empresas públicas participaron con 18250 millones de dólares; o sea el $43.5 \%$ del total del sector público. Las instituciones financieras con 15297 millones de dólares; esto es, el $36.5 \%$; el gobierno federal con 8368 millones de dólares, es decir, el $20 \%$ del total del sector público (cuadro 13).

Si observamos con detenimiento el cuadro podemos concluir que el mayor endeudamiento de dicho periodo se centra en los años que transcurren de 1977 a 1982, sobresaliendo 1981 y el primer semestre de 1982 .

Si consideramos los cuadros 14 y 15 en relación a las empresas públicas (Pemex, CFE, Nafinsa, EUM y Conasupo) se pueden obtener dos conclusiones: la primera es que el mayor numero de créditos los contrató Pemex y siguió la CFE. Además, si sumamos el monto de estas dos empresas y lo referimos al sector energético logramos obtener un total de 16017 millones de dólares de 1973-1982 (cuadro 14). Sin embargo, llama mucho la atención la contratación que hizo el gobierno mexicano a través de las siglas EUM por la cantidad de 8368 millones de dólares. Si a ello le sumamos el monto contratado por las instituciones como Nafinsa y Banobras obtenemos una suma de 23665 millones de dólares. Esto es impresionante: el gobierno federal por concepto de financiamiento contrató casi la mitad del $48 \%$ de la deuda externa del país o el $56 \%$ del sector público, préstamos que fueron obtenidos por las siglas EUM pero su destino no se encuentra localizado como sería el caso de Pemex y CFE. La única conclusión es que gran parte del capital se destinó a mantener una política, cuyo tipo de cambio fijo, propició la fuga de capitales.

En relación a las empresas públicas, éstas contrataron un monto de 17134 millones de dólares. Además de Pemex y CFE, las más representativas de la muestra fueron las siguientes: la Siderúrgica Lázaro Cárdenas con 405 millones de dólares; el restante lo contrató Teléfonos de México, S. A., Altos Hornos de México, S. A., Fertilizantes Mexicanos, S. A., 


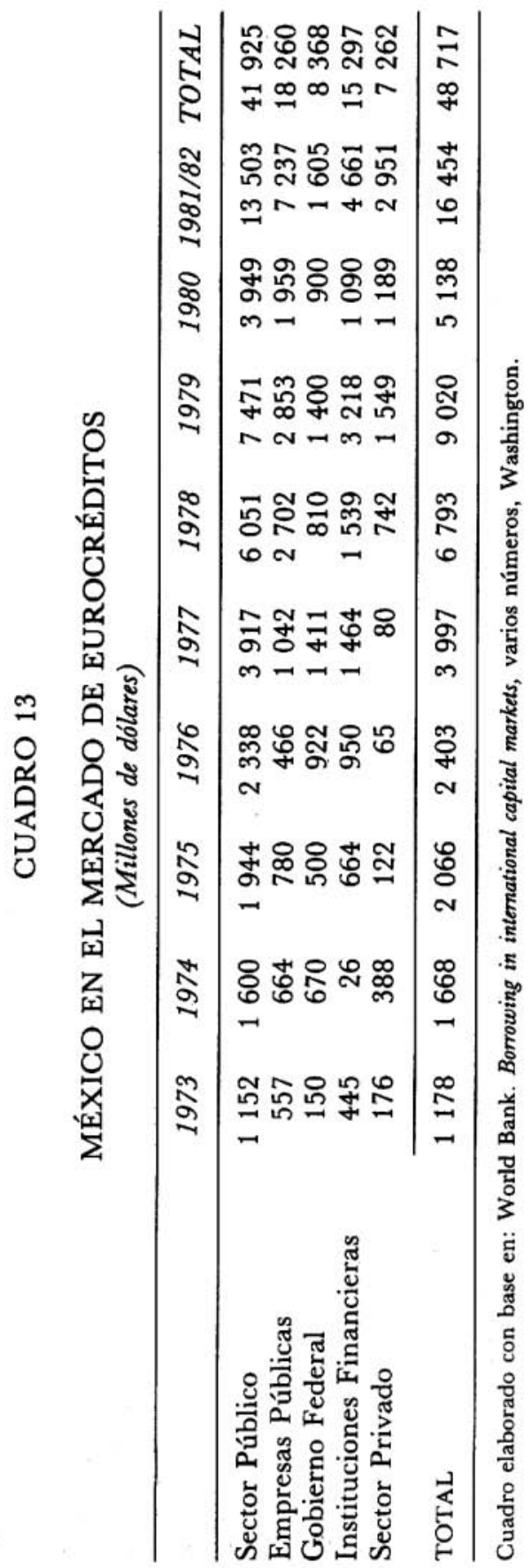


GUADRO 14

EMPRESAS PÚBLICAS MEXICANAS EN EL MERCADO DE EUROCRÉDITOS (Millones de dólares)

\begin{tabular}{|c|c|c|c|c|c|c|c|c|c|c|}
\hline & 1973 & 1974 & 1975 & 1976 & 1977 & 1978 & 1979 & \multicolumn{2}{|c|}{$19801981 / 82$} & TOTAL \\
\hline Pemex & 255 & 125 & 591 & 341 & 779 & 1363 & 1063 & 1162 & 6262 & 11941 \\
\hline CFE & 130 & 185 & 15 & - & 218 & 783 & 1560 & 375 & 810 & 4076 \\
\hline Conasupo & 22 & - & 24 & 25 & - & 15 & - & - & 40 & 126 \\
\hline Telmex & & & & 100 & 20 & 25 & - & 62 & - & 207 \\
\hline AHMSA & 81 & - & - & - & - & - & 100 & 184 & & \\
\hline Fertimex & 15 & - & - & - & - & - & 125 & 140 & & \\
\hline Mexicana de Papel Periódico & - & - & - & - & 25 & - & - & - & - & 25 \\
\hline Sicartsa & - & - & 30 & - & - & - & - & - & - & 30 \\
\hline Fundidora Monterrey & - & - & 105 & - & - & - & 300 & - & - & 405 \\
\hline TOTAL & 407 & 391 & 780 & 466 & 1042 & 2185 & 2623 & 1899 & 7337 & 11134 \\
\hline
\end{tabular}

FUENTE: World Bank. Borrowing in international capital markets, varios números, Washington. 


\section{CUADRO 15}

INSTITUCIONES FINANCIERAS EN EL MERCADO DE EUROCRÉDITOS

(Millones de dólares)

\begin{tabular}{lrrrrrrrrrr}
\hline & 1973 & 1974 & 1975 & 1976 & 1977 & 1978 & 1979 & $19801981 / 82$ & TOTAL \\
\hline Banobras & 300 & 220 & 180 & 280 & 234 & 517 & 600 & 100 & 1000 & 3531 \\
Nafinsa & 70 & 30 & 405 & 470 & 649 & 265 & 965 & - & 2040 & 4894 \\
Soc. Mex. Crédito Industrial & - & - & - & - & - & 250 & - & 400 & 650 & \\
Bancomext & - & - & - & - & 100 & 700 & - & 400 & 350 & 1550 \\
Bco. Nac. Pesquero y Portuario & - & - & - & - & - & - & - & 15 & 51 & 66 \\
Bco. Nac. Agropecuario & - & 15 & 29 & - & - & - & - & - & - & 45 \\
Bco. Nac. Crédito Rural & - & - & 20 & - & 196 & 657 & 1353 & - & 820 & 3046 \\
Fondo Especial Financ. Agrop. & - & - & - & - & - & 50 & - & - & - & 50 \\
Financiera Nac. Azucarera & 75 & - & 30 & 200 & 285 & - & 300 & $575-1465$ & \\
TOTAL & 445 & - & 266 & 664 & 1464 & 2539 & 3218 & 1090 & 4661 & 15297 \\
\hline
\end{tabular}

FUENTE: World Bank, Borrowing in international capital markets, varios números, Washington. 
Mexicana de Papel Periódico, S. A. y Fundidora de Monterrey, S. A.

En cuanto a las instituciones financieras, la tendencia a contratar préstamos a partir de 1977 se pronuncia con mayor dinamismo hasta 1982. Sorprende que el conjunto de dichas instituciones represente cerca del $36.5 \%$ del total; de ellas, el Fondo Especial de Financiamientos Agropecuarios, el Banco Nacional Agropecuario, S. A. y la Sociedad Mexicana de Crédito Industrial, S. A. son las que ocupan los tres primeros lugares y con montos menores le siguen el Banco Nacional de Crédito Rural, S. A., el Banco Nacional Agropecuario y el Banco Nacional Pesquero y Portuario, S. A.

Por lo que se refiere a las empresas privadas, el monto que representan es de 7262 millones de dólares. En este caso destaca la participación de las cementeras, siendo Cementos Tolteca, S. A. la que ocupa el segundo lugar con un total de 145 millones de dólares en el periodo 1973-1980. El primer lugar lo ocupaba Hylsa de México, perteneciente al Grupo Alfa. ${ }^{17}$

\section{El petróleo mexicano, el mercado de eurocréditos y la banca trasnacional}

El estudio del financiamiento de la banca internacional hacia grandes inversiones de México y su canalización a la construcción y ampliación de la plataforma petrolera, en el último lustro de la década de los años setenta, permite vislumbrar una línea más definida del papel desempeñado por la deuda externa mexicana en el contexto económico y político de la crisis del sistema capitalista.

La guerra del Yom Kipur propició el incremento de los precios del petróleo en $131 \%$ en enero de 1974 . Posteriormente, al estallar la revolución de Irán y cerrar los pozos petroleros en 1978 disminuyó la producción para el mercado mundial en un $40 \%$, precisamente cuando las reservas occidentales es-

17 Recuérdese que estas ideas las ampliamos en el capítulo 2. 
taban ya por debajo del nivel mínimo de seguridad. ${ }^{18} \mathrm{Du}$ rante estos años las reuniones entre México y Estados Unidos iniciaban una nueva época. El gobierno estadounidense se interesó en los mantos petroleros mexicanos y buscaba influenciar la explotación de los mismos para la exportación. Por ello, la banca trasnacional apoyaría la expansión de la industria petrolera. A tal grado que

cada barril de petróleo mexicano tiene un valor estratégico añadido, y esta circunstancia (además de la comercial) otorga una inusitada importancia a los mecanismos de decisión "dentro" del sistema político mexicano y de los organismos paraestatales como Petróleos Mexicanos (Pemex). ${ }^{19}$

En este marco es necesario destacar por qué el elevado nivel de endeudamiento de la empresa pública petrolera mexicana muestra concretamente la interdependencia estructural que significa el suministro de hidrocarburos a Estados Unidos y los países desarrollados. Y, más allá del hecho económico, reflejará la importancia de un mercado geopolíticamente estratégico, ejercido por las disposiciones de los compradores durante el decenio de los ochenta.

Es útil precisar lo anterior para articular nuestra hipótesis sobre el equivalente general y su relación con el financiamiento del petróleo en México, donde se congregan diferentes elementos de índole político, económico y social.

Así, en este apartado examinamos, en primer lugar, la fundamentación teórica del endeudamiento petrolero; en segundo, el crecimiento de Pemex de 1970-1982 y, por último, la trasnacionalización de la deuda externa de Pemex.

${ }^{18}$ Colmenares, Francisco. Petróleo y lucha de clases en México. 1864-1982. Ediciones El Caballito, México, 1982. Martínez Escamilla, Ramón. "A 50 años de la expropiación. El petr jleo mexicano en la estructura energética mundial" . Excélsior, México, 28 de febrero de 1988.

${ }^{19}$ Saxe Fernández, John. Petróleo y Estrategia: México y Estados Unidos en el contexto de la política global. Siglo XXI Editores, México, 1980. 
El endeudamiento petrolero en el ámbito de la crisis internacional de México

Sin duda el endeudamiento externo de un país como México, y específicamente una empresa pública como Pemex, no es una casualidad sino una causalidad de la inminente tendencia de la reproducción del capital y su necesidad de valorización en el marco de una crisis estructural del sistema capitalista. El equivalente general realizará en forma breve y por corto tiempo el fortuito papel necesario del intercambio de bienes y servicios para contrarrestar la crisis a nivel internacional. De allí que es necesario enunciar que la crisis de los energéticos no se produce como resultado del aumento de los precios del petróleo. La energía y el petróleo, ambas mercancías, forman parte de la crisis estructural de la economía capitalista, donde la revolución científico-técnica acompaña la década de los años setenta de características diferentes al periodo de la posguerra: bajos precios en los energéticos. La problemática de la energía, desde este punto de vista, amplía el análisis de la crisis estructural del sistema capitalista internacional..$^{20}$ Enfoque contrario es señalar la crisis de los energéticos como resultado del aumento de los precios del petróleo.

La llamada crisis energética es resultado, en parte, de la articulación de un excedente líquido de capital (producto del alza en los precios del petróleo en los años 1973 y 1974) que se recicla a través del financiamiento del déficit de cuenta corriente de los países importadores de petróleo. Tal mecanismo posterga la crisis económica mundial. Y, dentro del marco político de las naciones exportadoras, hace posible la supervivencia de "formas democráticas" sustentadas en "modelos viables", conteniendo la crisis en los países subdesarrollados.

${ }^{20}$ De la Vega Navarro, Angel. "La energía en el contexto de algunas tendencias recientes de la economía capitalista internacional". Conferencia presentada en el Ix Seminario de problemas de la economía mundial contemporánea. Doctorado de Economía de la División de Estudios de Posgrado. UNAM, 20 de enero de 1982. 
El círculo del endeudamiento se convirtió en una espiral necesaria para el mantenimiento de una economía cuyos insumos dependen sólo de Estados Unidos en un $80 \%$. Para seguir subsistiendo, el modelo mexicano necesita nueva liquidez, que constituye la causalidad en la relación entre los que prestan dinero y quienes lo utilizan para comprarle a los socios del prestamista. En esta espiral-causal del intercambio de bienes-trabajo por capital-trabajo, se profundiza la dependencia estructural entre acreedores y deudores. No debemos olvidar la participación de las Siete Hermanas: Standard Oil de New Yersey, Royal Dutch Shell (Shell), Mobil Oil (Mobil), Texaco, Inc. (Texaco), Gulf Oil (Gulf); Standard Oil of California (Socal) y British Petroleum (BP), cuyos objetivos de expansión son los mismos que los grandes bancos trasnacionales. ${ }^{21}$

La crisis económica envolvió a México desde el inicio de los años setenta, presentando la alternativa del desarrollo petrolero como una salida viable de consenso popular y de crecimiento económico. Hacia el final de un sexenio caracterizado por graves enfrentamientos entre el sector privado y el Ejecutivo (que fracasó en su decisión de mantener una política nacionalista con el deseo de participación popular), el nuevo régimen se abrió a la posibilidad de un pacto para favorecer las ganancias del sector privado y la credibilidad de un Estado aparentemente soberano en sus decisiones. La supeditación del país y de la política económica a la orquestación de un plan general y amplio como el del FMI, comprendió medidas económicas rígidas, que contribuyeron a restringir la producción de aquellos sectores que habían sido los más dinámicos de la economía desde la década de los años sesenta. ${ }^{22}$ La excepción recayó en el petróleo que, contando con la predilección oficial y de la banca privada internacional, fue el único que incurrió en una dinámica de crecimiento

${ }^{21}$ Tanzer, Michael. The political economy of international oil and the underdeveloped countries. Beacon Paperback 370 Economics, Boston, 1969.

${ }^{22}$ Véase capítulo 2. 
acelerado, dejando durante los tres primeros años del gobierno de López Portillo un saldo favorable en el sostenimiento de la tasa creciente del PIB, el mejoramiento del perfil de endeudamiento y de otros indicadores económicos. No obstante, en los dos últimos años de ese gobierno las tendencias se revirtieron.

Al subsidiar los energéticos para la industria, la política económica del Estado ocasionó que al ser más baratos en el interior que en el exterior, gran parte del sector manufacturero monopólico creciera a un ritmo de expansión acelerada, con un logro mayor en sus utilidades, pero sin mejorar ni ampliar la capacidad real de los salarios. ${ }^{23}$ El Estado, embarcado en el continuismo de una política dependiente de la inversión extranjera indirecta y directa, rehuyó una política fiscal redistributiva coherente con las necesidades populares para evitar enfrentarse a los grupos monopólicos. Es necesario señalar que

las estimaciones de hidrocarburos representaban, al inicio de los ochenta, el $93 \%$ del total de las fuentes primarias de energía en México. Además, mientras los impuestos sobre la producción de hidrocarburos proporcionaban la mitad de los ingresos al sector público, las tres cuartas partes de las entradas de divisas al país provenían de las exportaciones del petróleo y gas natural. ${ }^{24}$

El financiamiento al petróleo en México, en sí la reproducción de capital a nivel internacional, cumplió un objetivo económico concreto: dio posibilidad de resolver parcialmente la liquidez internacional. Pero 10 años después, ya en medio de la crisis, el desarrollo de dicho recurso no renovable proporciona un incremento sustancial a la reserva estratégica del Pentágono de Estados Unidos. Además, es indiscutible y del todo acertada la tesis de la capacidad estratégica del

${ }^{23}$ Véanse los informes de la misión del FMI sobre la economía de México y $\mathrm{Cu}$ rent economic position and prospects of Mexico 1977 y el correspondiente a 1981. ${ }^{24}$ Williams, A. James. El petróleo en México: efectos macroeconómicos, elementos y perspectivas. Programa de Energéticos. El Colegio de México, 1984. 
conglomerado trasnacional para sujetar a México como país productor de petróleo y debilitar estratégicamente a la Organización de Países Exportadores de Petróleo (OPEP) propiciando el fortalecimiento del mercado de compradores en la década de los años ochenta. Además de que México estuvo y está dentro del proyecto de Estados Unidos para la ocupación militar de pozos petroleros. ${ }^{25}$

Los años 1981 y 1985 fueron el inicio de la acelerada baja de los precios del petróleo a nivel internacional. La obtención de nuevas tecnologías para sustituir al petróleo hizo disminuir la demanda del producto y, por otra parte, la irracional explotación de dicho recurso no renovable en países como México, Venezuela, Ecuador y los países árabes, incrementó la oferta de dicha mercancía. De esta forma, el esplendor de la industria más dinámica en los años sestenta cambió su perfil al enfrentarse a un mercado debilitado y una carencia de financiamiento para nueva tecnología. La falta de recursos y de nueva deuda, para mantener la vanguardia en tecnología, demeritan cada vez más a una industria nacional envuelta en los deseos del capital trasnacional.

El desconcierto internacional provocado por el derrumbe de los precios del petróleo en el mercado mundial de hidrocarburos a principios de 1986, colocó a Pemex en una situación asfixiante que invalidó - por el momento- su lucha para continuar disminuyendo su endeudamiento externo echando por tierra la mitología del auge petrolero. ${ }^{26}$

\section{Del "crecimiento" al "desfinanciamiento" de Pemex}

En nuestro planteamiento teórico hemos demostrado la necesidad del equivalente general para participar en la financiación del proceso de valorización del capital. El petróleo mexicano,

${ }^{25}$ Mark, Clyde. "México en la mira de Estados Unidos para la ocupación militar de pozos petroleros"' en El Día, México, 9 de abril de 1981. Véanse también las opiniones de John Saxe Fernández.

${ }^{26}$ Acevedo Carrillo, Agustín. "La crisis de la deuda petrolera", (mimeo), Proyecto "Lázaro Cárdenas". FCPyS. UNAM. 
entonces, cumplirá con dichos requisitos, dado el entorno político reinante a nivel internacional. Entre las condiciones externas prevalecientes está la necesidad estratégica de Estados Unidos de proveerse de insumos necesarios para su aparato militar y su economía. Internamente, los efectos de la crisis estructural del capitalismo en nuestro país afloraron desde principios de la década del setenta, pero el petróleo y los recursos para su financiación permitieron posponer una reforma a fondo del aparato político, económico y social del país. Estos factores, además de otros, explican el crecimiento inusitado de Pemex a partir de 1973 y su despegue en $1977 .{ }^{27}$

a. Las inversiones corrientes pasaron de 17082 millones de pesos en 1973 a 38487 millones de pesos en $1976 ;{ }^{28}$ es decir, un crecimiento de $225.3 \%$. De 1977 a 1982 las inversiones corrientes aumentaron de 51209 millones de pesos a 639213 millones de pesos; es decir, un crecimiento de $1238.2 \%$. Sin embargo, durante los mismos años observamos una tendencia diferente para los gastos corrientes de la empresa petrolera. Así, tenemos que para 1973 los gastos corrientes son de 14295 millones de pesos y a 1976 dichos gastos ascienden a 24247 millones de pesos; es decir, el crecimiento fue de $169 \%$. De 1977 a 1982 los gastos pasan de 33589 millones de pesos a 351066 millones de pesos; o sea, un incremento de $1045 \%$. Esto indica que mientras los ingresos fueron de $225.2 \%$ y los gastos de $169 \%$ durante el periodo de 1973 a 1976 en el siguiente periodo el crecimiento significó $1248.2 \%$ frente a un gasto de 1045 por ciento.

$b$. Si observamos la inversión de Pemex en ambos periodos tenemos que el incremento de recursos para inversión pasó de 3687 a 16111 en 1976; es decir, un incremento porcentual de $437 \%$. De 1977 a 1982 los recursos para inversión pasaron de 18277 a 290503 millones de pesos; representando un incremento de $1589 \%$. Si los recursos para inversión aumentaron en $1589 \%$ y los ingresos corrientes $1248 \%$ y ${ }^{27}$ Cf. capítulo 2.

${ }^{28} \mathrm{La}$ información vertida en este apartado procede de Estado de ingresos y gastos de Pemex. Anexo estadístico del Informe de Gobierno. Varios años. 
los gastos corrientes $1045 \%$ no cabe la menor duda que el crecimiento de las inversiones de Pemex fue con endeudamiento externo.

c. Es importante mencionar la relación de la deuda externa de Pemex con los recursos de inversión.

La deuda externa de Pemex pasó de 727 millones de dólares en 1973 a 2221 millones de dólares de 1976; es decir, tuvo un incremento de $305 \%$. De 1977 a 1982 la deuda de Pemex pasó de 3083 millones de dólares a 15717 millones de dólares; es decir, 509\%. En 1982 la deuda externa de corto plazo de Pemex representaba el $25 \%$ del total de su deuda externa. En 1981 la deuda de corto plazo representó el $35.5 \%$. Ello indicaría que el crecimiento de 1977 a 1982 se planteó con base en el endeudamiento externo sin prever la insolvencia financiera en que caería, años después, por el entorno de la tendencia descendente de los precios internacionales del petróleo.

d. De 1982 a 1986 los gastos corrientes pasaron de 639213 a 3663431 billones de pesos. La cifra representa un incremento de $573 \%$. Los ingresos corrientes pasaron de 351066 a 2594883 es decir, un incremento de $739 \%$. Los recursos para inversión pasaron de 290503 a 1068548 de pesos; es decir un incremento de $368 \%$. En tanto, la deuda externa pasó de 15717 a 14829 millones de dólares; es decir, tuvo un decremento de $6 \%$, lo cual indica que la inversión de la empresa paraestatal se ha rearticulado a los lineamientos del Plan de Desarrollo 1983-1988. Esto es, pagar la deuda externa y seguir renegociando ésta a plazos más largos, disminuyendo, por otro lado, las nuevas inversiones sin perjudicar el problema social que implicaría un recorte en los gastos corrientes.

Para concluir el análisis del estado de ingresos y gastos de Petróleos Mexicanos, podemos afirmar que uno de los elementos más dinámicos ha sido el de los gastos corrientes. Durante el periodo 1977-1982, tuvo un incremento de $1045 \%$, cantidad superior a la alcanzada en el periodo 1973-1976. Este crecimiento de los gastos corrientes es mucho más dinámico 
que el de la deuda externa, puesto que los incrementos de ésta han sido en los mismos periodos los siguientes: 32.7 y $509 \%$ en 1977-1982 y el decremento sustancial del $6 \%$ de 1982 a 1986.

Llama la atención el renglón de recursos para inversión el cual tuvo un incremento durante $1982-1986$ de $368 \%$, incremento inferior al del periodo 1973-1976 que fue de $437 \%$ e inferior al incremento alcanzado durante 1977-1982 que alcanzó $1589 \%$, incremento que difícilmente volvería a alcanzar Pemex en su historia futura de corto plazo.

El motivo del creciente endeudamiento externo de Pemex con bancos trasnacionales radicó principalmente en la necesidad de financiar sus planes de inversión. La falta de una política económica orientada a fomentar el desarrollo de renglones prioritarios a nivel nacional, y de una gestión administrativa coherente en la canalización de sus gastos de capital, desembocó en la insolvencia financiera de Pemex, institución pilar del discurso nacionalista del Estado. Su dependencia de las oscilaciones de la economía internacional se profundizó no sólo en cuanto a las presiones del mercado de exportación, sino ante el riesgo que representó el incremento creciente de sus pasivos en dólares. ${ }^{29}$

e. A manera de síntesis es necesario resaltar el periodo 1970-1980. Las inversiones de Pemex, las mayores frente a otras empresas públicas por el dinamismo de su crecimiento, pasaron de aproximadamente un $7 \%$ de la inversión bruta fija en 1975 al $19 \%$ en 1980 . Dentro del gasto total del sector federal consolidado, las inversiones de Pemex participaron en 1980 con un $29 \%$ a diferencia del $13 \%$ que recibieron en 1975. La cuenta corriente y la de capital crecieron exponencialmente en dicho periodo conjuntamente con las inversiones y el aumento neto de la deuda externa. La estructura administrativa de la empresa, desde años anteriores, trabajaba con saldos rojos y continuó acarreande fallas estructurales de administraciones pasadas que se volvieron un círculo

${ }^{29}$ Véase capítulo 2. 
vicioso a partir de 1975 y 1976 , penetrando hondamente en un déficit crónico en el momento coyuntural de la economía internacional de 1977 a 1980.

$\mathrm{Al}$ analizar la década de los años setenta y dividirla en dos periodos, se puede observar que en el primero (de 1971 a 1975 donde el petróleo no es un sector de punta en el mercado del país), las inversiones tuvieron un monto acumulado de 39638 millones de pesos. El faltante para inversión acumulada fue de -11526 millones; es decir, $29.07 \%$ del total requerido; dicho faltante se complementó con un aumento neto de deuda externa que fue de 38426 millones, de los cuales 30042 se canalizaron al pago de amortizaciones. En el segundo periodo (1976-1980) el monto acumulado de las inversiones fue de 384455 millones de pesos. El faltante para inversiones fue mucho mayor al del periodo anterior: 161767 millones de pesos; es decir, $42.07 \%$ del requerido. Se completó con un aumento neto de deuda externa de 382318 millones de pesos; es decir, $99.4 \%$ del total para inversiones.

La pregunta es ¿por qué si el faltante para inversión representa $42.07 \%$, el aumento neto del endeudamiento es de $99.4 \%$ ? La respuesta sería que por concepto de amortización de deudas se pagaron 229451 millones de pesos. De ahí concluimos que el aumento neto acumulado de deuda externa reflejó una mayor canalización hacia el pago de amortizaciones.

El estudio del estado de ingresos y gastos de Pemex mostraba una necesidad de financiamiento externo continua y exponencial. De esta forma observamos para 1980 lo siguiente:

1) Los gastos corrientes representaron el $80.3 \%$ del total de los ingresos.

2) El ahorro ocupó el 19.7 por ciento.

3) Las inversiones alcanzaron 147875 millones de pesos, $56.3 \%$ de los gastos corrientes; por tanto, se hizo necesario acudir al financiamiento externo.

4) Los recursos para inversión representaban únicamente 43 por ciento.

5) El faltante para inversión fue de 56.4 por ciento. 
El endeudamiento neto para 1980 alcanzó 65815 millones de pesos. El pago por amortización requirió $90428 \mathrm{mi}-$ llones, para lo cual se colocaron empréstitos por 156243 millones de pesos. Si bien una parte fue para la renegociación y pago de la deuda, la otra se destinó a las inversiones de la empresa, recursos que posteriormente pasarían a formar parte del grueso de los gastos corrientes de Pemex.

El círculo deficitario en el cual se vio envuelta la empresa profundizó la relación de sus exportaciones con los cambios oscilantes del comercio exterior. Posteriormente, a la baja de los precios internacionales del petróleo, el endeudamiento siguió siendo el punto de arranque para la producción de Pemex. En el marco de la dependencia estructural de nuestro país con Estados Unidos esta situación parece no tener remedio. La condición estratégica que reviste el petróleo para la política económica indujo al Estado a seguir canalizando enormes empréstitos hacia esa industria en el periodo coyuntural 1981-1982. ${ }^{30}$ La evaluación de Pemex, realizada por la Secretaría de Programación y Presupuesto, señaló:

es necesario aclarar que los problemas de esta índole han sido arrastrados por varias administraciones y que en la coyuntura económica que prevalecía a principios del actual régimen, su atención se tuvo que postergar ante la prioridad de incrementar rápidamente la producción, requisito indispensable para satisfacer otras necesidades del orden nacional. ${ }^{31}$

Al prevalecer una mala administración en Pemex y dado el momento coyuntural de 1975-1976 y la necesidad de postergar la crisis económica del país, se hizo necesario el incremento de las inversiones provenientes del financiamiento externo para la exportación del petróleo, sin resolver problemas internos de la institución.

30 Ibid.

31 Ramírez, Carlos. "Versión periodística del Documento de la Secretaría de Programación y Presupuesto", en Proceso, México, 25 de mayo de 1981. y Pemex: la caída de Díaz Serrano. Proceso, 1981. 
La trasnacionalización de la deuda externa de Pemex

La trasnacionalización de la deuda externa permitirá observar el financiamiento del petróleo dentro del ciclo de reproducción ampliada del capital. El reciclaje del capital de préstamo destinado a la producción y circulación de mercancias hará posible el retorno al país del acreedor no sólo del dinero valorizado, sino las mercancías producto del préstamo. El cuadro 16 muestra algunos aspectos del endeudamiento externo de Petróleos Mexicanos con sus propias características en el transcurso de la década de los años setenta.

El cuadro señala que de 1973 hasta el primer semestre de 1982 los acreedores de Pemex fueron: Bank of America, Bank of Montreal, Bank of Tokio, Bankers Trust Ltd., Canadian Imp., Bank Commerce, Chemical Bank, First National City Bank, City Corp., European American \& Trust Co., Mitsubishi Ltd., Mitsui Bank Ltd., Bank of Japan, Commerzbank Ag., bancos de origen mexicano como Banco Nacional de México, S. A., Banca Serfín, S. A. y Banco Internacional S. A.

Los préstamos trasnacionales a Pemex sumaron la cantidad de 12241.6 millones de dólares entre 1973 y 1982 . Durante 1981 y el primer semestre de 1982 obtuvo la suma de 6562.2 millones de dólares; es decir, más de la mitad de los préstamos fueron contratados durante un periodo de año y medio.

$\mathrm{Al}$ analizar dichos préstamos entre 1973 y 1982 en el mercado de los eurodólares, se pueden enumerar varias características singulares. En primer lugar la duración de los préstamos - que en un principio eran de 10 a 15 años - se redujeron a periodos de cinco a 10 años en promedio. Incluso los préstamos contratados durante 1973 y 1975 en su mayoría son a 10 años, no así los préstamos que corren a partir de 1979 cuya duración es, en promedio, de cinco años.

Por el contrario, las tasas de interés aumentaron. Estas tasas, que a mediados de los setenta fueron de entre 8 y $10 \%$, subieron hasta $19 \%$, con una tendencia a la baja, muy le- 
CUADRO 16

EMPRESAS PRIVADAS MEXICANAS EN EL MERCADO DE EUROCRÉDITOS

(Millones de dólares)

\begin{tabular}{|c|c|c|c|c|c|}
\hline NOMBRE & $1973 / 78$ & 1979 & \multicolumn{3}{|c|}{1980 1981/82 TOTAL } \\
\hline Acumuladores Mexicanos & & & 2 & & 2 \\
\hline Auris & & 39 & & & 39 \\
\hline Austroplán & 38 & & & 38 & \\
\hline Banca Serfín & & & 25 & & 25 \\
\hline Banco Nacional de México & & & 40 & & 40 \\
\hline $\begin{array}{l}\text { Celanese Mexicana } \\
\text { Cementos Anáhuac del }\end{array}$ & 100 & 52 & 90 & 125 & 367 \\
\hline Golfo & & & & 55 & 55 \\
\hline Cementos Anáhuac & 23 & & & 85 & 108 \\
\hline Cementos Cruz Azul & & 15 & & & 15 \\
\hline Cementos Mexicanos & & 31 & & & 31 \\
\hline Cementos Tolteca & 145 & & & 210 & 355 \\
\hline Cervecería Moctezuma & & & & 130 & 130 \\
\hline Kindy & & & & 55 & 55 \\
\hline Mexicana del Cobre & & 660 & & & 660 \\
\hline Minera de Cananea & & 150 & & & 150 \\
\hline Minera Autlán & & 65 & & & 65 \\
\hline Conductores Monterrey & & & & 100 & 100 \\
\hline Cristales Mexicanos & & & 46 & & 46 \\
\hline $\begin{array}{l}\text { Cydsa } \\
\text { Empresa Tolteca (Grupo }\end{array}$ & & & & 268 & 268 \\
\hline $\begin{array}{l}\text { ICA) } \\
\text { ICA }\end{array}$ & & & & 209 & 209 \\
\hline Fabricación de Máquinas & & & & 16 & 16 \\
\hline $\begin{array}{l}\text { Fibras Químicas S. A. } \\
\text { (Alfa) }\end{array}$ & & & & 50 & 50 \\
\hline $\begin{array}{l}\text { Fomentos de Inds. y } \mathrm{Co}- \\
\text { mercio Priv. } \\
\text { Fomento Económico } \mathrm{Me}-\end{array}$ & & 12 & & & 12 \\
\hline $\begin{array}{l}\text { Fomento Económico Me- } \\
\text { xicano }\end{array}$ & & & & 300 & 300 \\
\hline Ford Motor Company & & & & 326 & 326 \\
\hline Grupo Continental & & & & 22 & 22 \\
\hline Grupo Industrial Alfa & & 75 & & 60 & 135 \\
\hline $\begin{array}{l}\text { Grupo Mexicano de Desa- } \\
\text { rrollo }\end{array}$ & & & & 15 & 15 \\
\hline Grupo Pliana & & & 30 & & 30 \\
\hline
\end{tabular}


Continúa GUADRO 16

\begin{tabular}{|c|c|c|c|c|c|}
\hline NOMBRE & $1973 / 78$ & 1979 & 1980 & $1981 / 82$ & TOTAL \\
\hline \multicolumn{6}{|l|}{ Hylsa de México (Grupo } \\
\hline Alfa) & 35 & 65 & 145 & 60 & 305 \\
\hline Minera México & 200 & & & 500 & 700 \\
\hline Química del Istmo & 12 & & & & 12 \\
\hline Nacobre & & & 77 & & 77 \\
\hline Peñoles & 40 & & & & 40 \\
\hline \multicolumn{6}{|l|}{ Industrias Resistol (Grupo } \\
\hline Desc) & & & 17 & 24 & 41 \\
\hline Inversión y Asesoría & 10 & & & & 10 \\
\hline Kimberly Clark & & & 210 & & 210 \\
\hline Metalber & & & 4 & & 4 \\
\hline Mexicana de Aviación & & & 41 & 73 & 114 \\
\hline Mexicana de Cobre & 920 & 160 & & & 1080 \\
\hline Multibanco Comermex & & 25 & & & 25 \\
\hline Negromex & & & 25 & & 25 \\
\hline Obras y Proyectos & & & & 10 & 10 \\
\hline Perforaciones Marítimas & & & & & \\
\hline Mex. & & 23 & & & 23 \\
\hline \multicolumn{6}{|l|}{ Perforadora y Constructora } \\
\hline El Aguila & & 24 & & & 24 \\
\hline Pesquera Zapata & & 15 & & & 15 \\
\hline Petrocel & & & 17 & & 17 \\
\hline PIPSA & & 6 & & & 6 \\
\hline Salinas y Rocha & & & 9 & 40 & 49 \\
\hline Cemento Portland & & & 15 & & 15 \\
\hline Spicer & & & 70 & & 70 \\
\hline TAMSA & & & & 175 & 175 \\
\hline \multicolumn{6}{|l|}{ Transportación Marítima } \\
\hline Mexicana. & & 17 & & & 17 \\
\hline Tubos de Acero de México & & 130 & 60 & & 190 \\
\hline Union Carbide Mexicana & & & & 27 & 27 \\
\hline Valores Industriales & & & 150 & & 150 \\
\hline Vidriera Monterrey & & & 76 & & 76 \\
\hline TOTAL & 1523 & 1549 & 1164 & 2951 & 7187 \\
\hline
\end{tabular}

FUENTE: World Bank, Borrowing in international capital markets, varios números, Washington. 
ve, en 1980. Los préstamos otorgados al petróleo se vieron beneficiados por diferenciales menores ya que Pemex, por sus características coyunturales en los mercados internacionales, fue considerado un cliente distinguido.

Los bancos que han otorgado mayores créditos, como hemos señalado, pertenecen a consorcios internacionales estadounidenses, japoneses, alemanes y canadienses e incluso algunos mexicanos. Hay periodos durante 1976 y 1977 en que fueron los bancos estadounidenses quienes participaron con mayores montos en los préstamos otorgados a Pemex. En los años subsiguientes predominaron los bancos franceses y japoneses. No debemos olvidar la pérdida de hegemonía de los bancos estadounidenses frente a los japoneses durante el inicio de los años ochenta y el interés de este país por ampliar su área de influencia a la que se denominaría, años después, La Cuenca del Pacífico.

Es importante recalcar que uno de los acreedores más activos, en relación a Pemex y a México, fue el Bank of America; este encabezó junto con bancos japoneses un préstamo por mil millones de dólares. En 1981 el Bank of America, el Bank of Montreal y bancos japoneses, otorgaron un préstamo por 4 mil millones de dólares.

$\mathrm{El}$ interés de los bancos estadounidenses en proporcionar recursos necesarios para el petróleo estuvieron presentes por los intereses políticos, económicos y sociales de dichos años. México sobrepasó, incluso, el nivel de endeudamiento que los bancos estadounidenses deben otorgar a un solo país, pues se otorgaron préstamos a la CFE, Nacional Financiera, etc. Se calcula que cerca del $70.1 \%$ de la deuda externa total del país - considerando la del sector privado - fue contratada con Estados Unidos. Situación no permitida por la legislación bancaria estadounidense, la que protege del riesgo contra la incapacidad de pago o insolvencia de un país ante la quiebra de sus propias instituciones bancarias. ${ }^{32}$ Por otra

${ }^{32}$ Green, Rosario. Estado y banca trasnacional en México. CEESTEM-Nueva Imagen. México, 1981. La autora ha demostrado la dependencia financiera con Estados Unidos y la tendencia a la "norteamericanización" de la deuda externa mexica- 
parte, la Secretaría de Hacienda siempre remarcó la necesidad de ampliar su cartera de acreedores, acudiendo a banqueros japoneses y franceses en los últimos años del sexenio lópezportillista.

Los préstamos de Pemex con la banca trasnacional ligaron la empresa con los intereses de los grandes consorcios internacionales, cuyas inversiones están relacionadas con los intereses del comercio y de la producción trasnacional. Nada menos que el $44.5 \%$ de las exportaciones mexicanas - más de 733 mil barriles de petróleo crudo a Estados Unidos - se realizaron a través de tres gigantescos consorcios trasnacionales que figuran entre los más poderosos de las Siete Hermanas con una irradiación mundial: Exxon, Shell y Standard Oil; otros doce monopolios compran un $33.6 \%$ más, entre ellos la Texaco y la Down Chemical, de modo que 14 consorcios adquieren $78.1 \%$ de aquel total. ${ }^{33}$ Además, de todas las ventas realizadas para finales del año 1979, Estados Unidos recibió el $53 \%$, Europa (España, Francia y Suecia) $28.1 \%$, Japón $7.2 \%$, Canadá $3.5 \%$, Israel $3.2 \%$, mientras que a los países subdesarrollados (América Latina, India y Yugoslavia) sólo se les vendió el 5 por ciento.

Al observar el cuadro de los acreedores de Pemex y detectar a los más activos, concluimos que la intermediación financiera, vía la banca trasnacional, sirvió para el suministro de energéticos baratos a Estados Unidos, Europa y Japón, de manera prioritaria. La necesidad de financiar un proyecto

na, la cual ha llegado a presentar cerca del $70 \%$ en relación con otros acreedores internacionales. En el artículo "Notas sobre algunas interrogantes de la deuda externa de México", señalaba: "De hecho se ha venido siguiendo una política liberada de diversificación geográfica de la deuda. La participación relativa de los Estados Unidos de América bajó del $97 \%$ a menos del $27 \%$ entre 1977 y 1978, el hueco fue cubierto por una mayor participación de los bancos de Europa, Japón y Canadá". Secretaría de Hacienda y Crédito Público. Respuesta del licenciado Oscar Levín Coppel. Director de Crédito, Washington, D.C., 28 de septiembre de 1980. Véase la Bank Holding Act en "Cambios en la legislatura bancaria", en Gorostiaga, Xavier. Los centros financieros internacionales. Publicaciones del ILET, México, 1978, p. 46.

${ }^{33}$ Carmona, Fernando. "La crisis capitalista está en el petróleo", en Estrategia, núm. 41, septiembre-octubre, 1981. 
de largo plazo a nivel internacional y recircular la liquidez del sistema capitalista, desde mediados de los años setenta, permitió la financiación de un sector de punta necesario en el proceso de acumulación de capital.

El riesgo que México tuvo frente a la comunidad financiera al presentar la crisis de liquidez, acompañada del descenso paulatino de los precios del petróleo, afectó la rentabilidad de la empresa e incluso a la disminución de su capital y de liquidez del sistema capitalista internacional. Los años comprendidos entre 1982 y 1987 se sujetaron a los lineamientos del FMI y a la renegociación de la deuda externa sacrificando los programas de inversión. Al respecto Colmenares señala:

El desendeudamiento que comenzó a registrar la industria petrolera desde 1982, y que se mantuvo hasta 1984, determinó que su participación en el endeudamiento del sector público disminuyera. Sin embargo, continuaba siendo muy alta, tanto su participación como el monto del endeudamiento petrolero. En 1984 la participación de la deuda de Pemex en la deuda pública representaba el doble de lo que representaba entre 1970 y 1976 . Es decir, el auge petrolero interno indujo a la industria en la trampa financiera en que fue arrastrada la economía mexicana, sin lograr, todavía, escapar de ella. En la medida que a la industria petrolera se le ha obligado a ajustar sus excedentes financieros a los requerimientos financieros del gobierno federal y contribuir apenas al pago de los intereses de la deuda externa, la posibilidad de llegar a situarse en una plena autonomía financiera se ha ido posponiendo indefinidamente. ${ }^{34}$

La renegociación de la deuda externa de Pemex tiene estrecha relación con el crecimiento de la industria petrolera y de la economía en su conjunto. La reestructuración de la deuda petrolera ha implicado la postergación de nuevas inversiones y el pago de su deuda se complica ante la baja tendencial de los precios del petróleo y la incertidumbre reinante

${ }^{34}$ Colmenares, Francisco. "Problemas de rentabilidad y productividad de la industria petrolera mexicana. 1970-1984." Tesis de Maestría. Centro de Estudios Latinoamericanos. FCPyS. UNAM. y "El excedente petrolero en el auge de la crisis de México. (1970-1984)", véase Edgar Ortiz (compilador). Empresas Públicas. Problemas actuales de norteamérica y el Caribe México. CIDE-NAEFA, 1988, pp. 48-63. 
en el mercado internacional. La abundancia, a la que debimos prepararnos para administrarla a finales de los años setenta, se convirtió en una abundancia administrativa para pagar eficientemente el servicio de una deuda externa que petrolizó la economía nacional en toda su estructura interna. Al disminuir los ingresos petroleros por la baja de los precios del petróleo y los ingresos tributarios del gobierno federal por la caída de sus ventas, el gobierno vio afectados sus planes de inversión canalizando toda la reestructuración de la economía al pago de la deuda externa global. En referencia a lo anterior, el Programa de Energéticos indica:

Ciertas consideraciones generales permiten señalar que la reducción en un dólar en el precio del crudo reduce en aproximadamente 500 millones de dólares los ingresos en divisas, mientras que, por su parte, el incremento en $1 \%$ de la tasa de interés implica que la deuda externa de México crezca en alrededor de 800 millones de dólares. ${ }^{35}$

Los hechos muestran la adversidad en la que se encuentra la economía mexicana al haberse obligado a un proyecto de inversión trasnacional. La baja de los precios del petróleo y el incremento de las tasas de interés incidirán, automáticamente, en un mayor incremento del pago del servicio de la deuda externa con las implicaciones políticas, económicas y sociales correspondientes.

${ }^{35}$ Márquez, Miguel H. La industria del gas natural en México. Programa de Energéticos. El Colegio de México, julio de 1988, publicado en Problemas del Desarrollo. IIEc-UNAM, núm 75 . 
CUADRO 17

PETRÓLEOS MEXICANOS

(Millones de dólares)

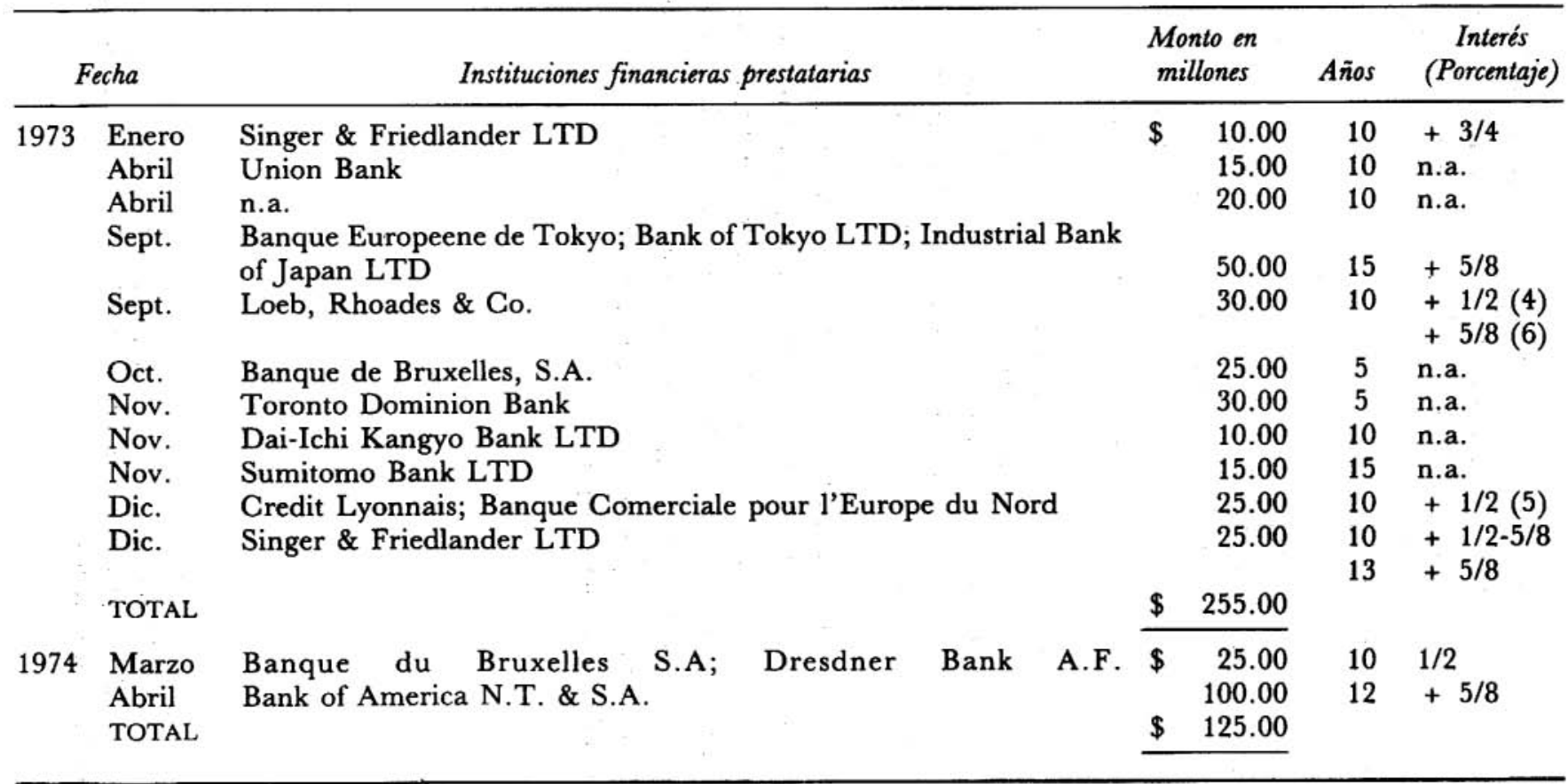




\begin{tabular}{|c|c|c|c|c|c|c|}
\hline \multicolumn{2}{|c|}{ Fecha } & Instituciones financieras prestatarias & \multicolumn{2}{|c|}{$\begin{array}{c}\text { Monto en } \\
\text { millones }\end{array}$} & Años & $\begin{array}{c}\text { Interés } \\
\text { (Porcentaje) }\end{array}$ \\
\hline 1975 & Mayo & $\begin{array}{l}\text { First Boston (Europe) LTD; Kuhn, Loeb \& Co. Bankers Trust Co.; } \\
\text { Bank International LTD; Royal Bank of Ganada; Westdeutsche Lan- } \\
\text { desbank Girozentrale. } \\
\text { Bank of América N.T. \& S.A.; Chemical Bank; Citicorp Internatio- } \\
\text { nal Bank LTD, Continental Bank; First Chicago Panama S.A.; Mor- } \\
\text { gan Guaranty Trust Co.; Chase Manhattan Bank N.A.; Royal Bank } \\
\text { of Canada; Westdeutsche Landesbank Girozentrale; Algemene Bank } \\
\text { Nederland N. V.; Bank of Nova Scotia; Commerzbank A.G.; Credit } \\
\text { Lyonnais; First Pennsylvania Bank N.A.; Nordeutsche Landesbank } \\
\text { International S.A. Luxembourg; Security Pacific National Bank. } \\
\text { International Mexican Bank LTD; Singer \& Friedlander LTD; Wo- } \\
\text { baco Investment LTD; Canadian Imperial Bank of Commerce; Iran } \\
\text { Overseas Investment Bank LTD; First National Bank of Memphis; } \\
\text { National Bank of Detroit. }\end{array}$ & $\$$ & 380.00 & 5 & $+11 / 2$ \\
\hline & TOTAL & & $\$$ & 591.00 & & \\
\hline 1976 & Mayo & $\begin{array}{l}\text { Citicorp International Group; Chase Manhattan LTD; Security Pa- } \\
\text { cific National Bank; Bank of Montreal; Banco Nacional de México, } \\
\text { S.A.; First Chicago Panama S.A.; Bank of Nova Scotia Internatio- } \\
\text { nal LTD; Morgan Guaranty Trust Co; Algemene Bank Nederland } \\
\text { N.V.; Barclays Bank International LTD; Commerzbank A. G.; Con- } \\
\text { tinental Bank; Crocker National Bank; International Mexican Bank, } \\
\text { LTD; Girard Trust Bank; Banca de Gottardo; Bank of New York; } \\
\text { National Bank of Detroit; First Pennsylvania Bank N. A.; Orion Bank } \\
\text { LTD }\end{array}$ & $\$$ & 300.00 & 5 & $+11 / 2$ \\
\hline
\end{tabular}




\section{Continúa CUADRO 17}

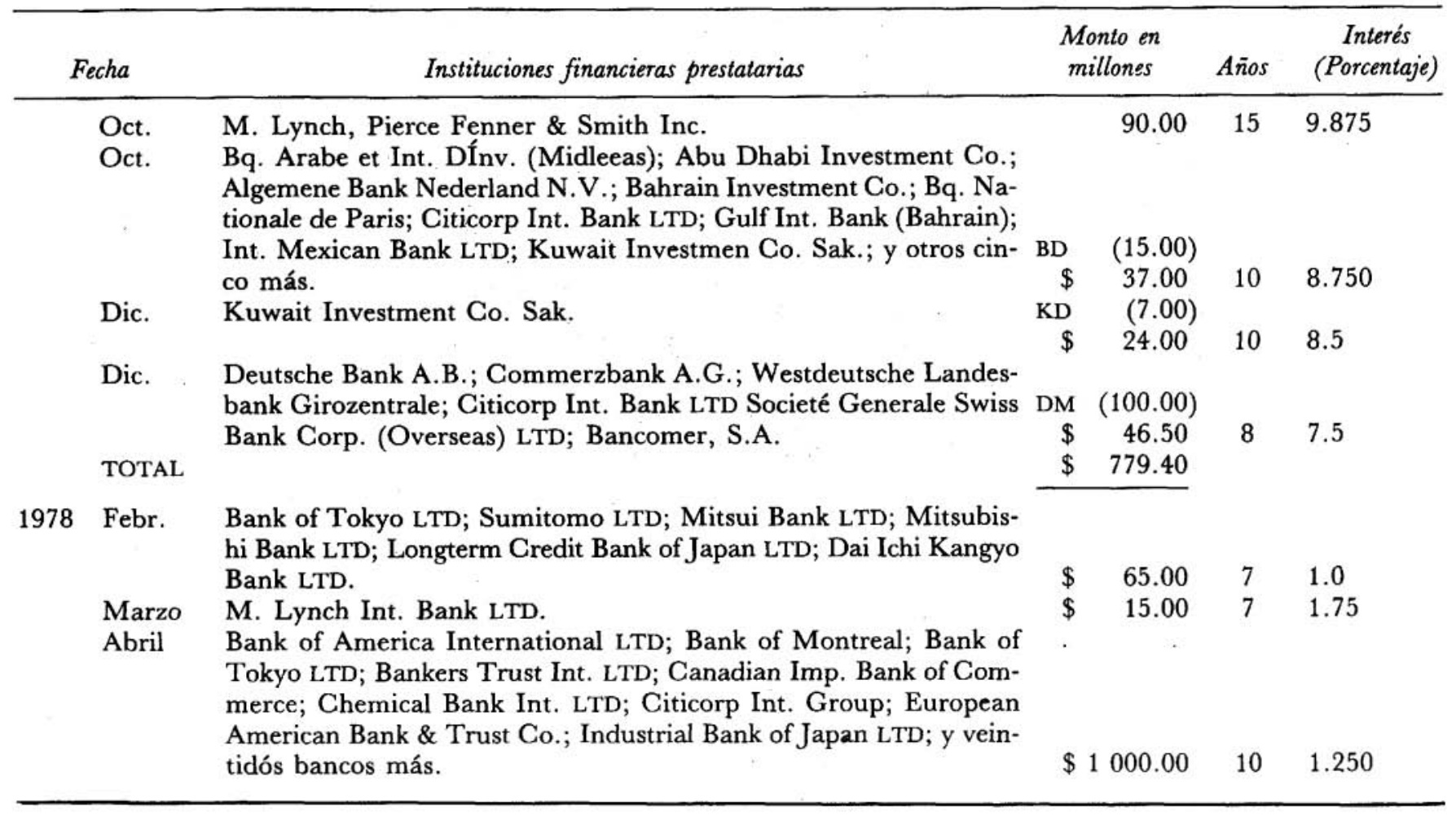




\begin{tabular}{|c|c|c|c|c|c|c|}
\hline \multicolumn{2}{|c|}{ Fecha } & Instituciones financieras prestatarias & \multicolumn{2}{|c|}{$\begin{array}{l}\text { Monto en } \\
\text { millones }\end{array}$} & \multirow[b]{2}{*}{$\begin{array}{c}\text { Años } \\
15 \\
\text { n.a. } \\
\text { n.a. } \\
\text { n.a. } \\
5 \\
5\end{array}$} & $\begin{array}{c}\begin{array}{c}\text { Interés } \\
\text { (Porcentaje) }\end{array} \\
9.875\end{array}$ \\
\hline & $\begin{array}{l}\text { Agt. } \\
\text { Agt. } \\
\text { Agt. } \\
\text { Sept. } \\
\text { Sept. } \\
\text { Nov. } \\
\text { TOTAL }\end{array}$ & $\begin{array}{l}\text { M. Lynch; W. Weld Capital Markets Group. } \\
\text { Syndicate of Mexican Banks } \\
\text { Toronto-Dominio Bank } \\
\text { Barclays Bank International LTD } \\
\text { Commerzbank A.G. } \\
\text { Bank of Tokyo LTD }\end{array}$ & $\$$ & $\begin{array}{r}50.00 \\
56.50 \\
50.00 \\
25.00 \\
50.00 \\
51.00 \\
362.50\end{array}$ & & $\begin{array}{l}9.875 \\
\text { n.a. } \\
\text { n.a. } \\
\text { n.a. } \\
0.750 \\
0.875\end{array}$ \\
\hline 1979 & $\begin{array}{l}\text { Feb. } \\
\text { Marzo } \\
\text { Abril } \\
\text { Mayo } \\
\text { Mayo } \\
\text { Julio } \\
\text { Julio }\end{array}$ & $\begin{array}{l}\text { Manufacturers Hannover LTD; Credit Commercial de France S.A.; } \\
\text { Bank of America Int. LTD; Bankers Trust Int. LTD; Bruxelles Lam- } \\
\text { bert S.A.; Chase Manhattan LTD; Commerzbank A.G.; Concenty } \\
\text { Bank LTD; Kredietbank S.A.; Luxembourgeoise; y otros cuatro más. } \\
\text { Union Bank of Swit (Securities) LTD } \\
\text { Banco Nacional de México, S.A. } \\
\text { Chemical Bank } \\
\text { Sumitomo Bank LTD; Barclays Bank Int. LTD; Cie Luxembourgeoi- } \\
\text { se de Dresdner Bank; Taiyo Kobe Bank LTD; Tokai LTD. } \\
\text { Midland Bank LTD. } \\
\text { Bank of Tokyo LTD. } \\
\text { Long Term Credit Bank of Japan LTD; Mitsui Bank LTD; Tokai Bank } \\
\text { LTD; Fuji Bank LTD; Sanwa Bank LTD; Mitsubishi Bank LTD. } \\
\text { Goldman Sachs \& Co. }\end{array}$ & $\begin{array}{l}\$ \\
\$ \\
\$\end{array}$ & $\begin{array}{r}100.00 \\
50.00 \\
240.00 \\
80.00 \\
\\
125.00 \\
50.00 \\
125.00 \\
\\
100.00 \\
73.00\end{array}$ & $\begin{array}{c}5 \\
5 \\
3 \\
10\end{array}$ & $\begin{array}{l}0.250 \\
0.625 \\
0.5 \\
0.75 \\
\\
0.750 \\
0.625 \\
0.625\end{array}$ \\
\hline
\end{tabular}


Continúa CUADRO 17

\begin{tabular}{|c|c|c|c|c|c|}
\hline \multicolumn{2}{|c|}{ Fecha } & Instituciones financieras prestatarias & $\begin{array}{c}\text { Monto en } \\
\text { millones }\end{array}$ & Años & $\begin{array}{c}\text { Interés } \\
\text { (Porcentaje) }\end{array}$ \\
\hline & $\begin{array}{l}\text { Sep. } \\
\text { TOTAL }\end{array}$ & Banco Serfin, S.A. & $\begin{array}{r}120.00 \\
\$ 1063.00\end{array}$ & - & - \\
\hline 1980 & $\begin{array}{l}\text { Enero } \\
\text { Mayo } \\
\text { Sept. }\end{array}$ & $\begin{array}{l}\text { Citibank N.A. } \\
\text { Swiss Bank Corp. } \\
\text { Societé Generale; Bq. Nationale de Paris; Credit Lyonnais; Bq. de } \\
\text { Paris et des Pays-Bas; Credit Commercial de France, S.A.; Bq. Fran- }\end{array}$ & $\begin{array}{lr}\$ & 37.00 \\
\$ & 125.00\end{array}$ & $\begin{array}{c}10 \\
8\end{array}$ & $\begin{array}{l}10.0 \\
11.5\end{array}$ \\
\hline & TOTAL & $\begin{array}{l}\text { caise du Commerce Exterieur. } \\
\text { Morgan Guaranty Trust Co.; Algemene Bank Nederland N.V.; Bank } \\
\text { of Tokyo Group; Credit Lyonnais; Manufactures Hannover LTD; } \\
\text { Nat. Westmister Bank LTD; Royal Bank of Canada (London LTD), } \\
\text { Swiss Bank Corp. Int. LTD; Mitsui Bank LTD. }\end{array}$ & $\begin{array}{r}500.00 \\
\$ 1162.00 \\
\end{array}$ & 2 & 0.250 \\
\hline 1981 & Junio & $\begin{array}{l}\text { Bank of America NT \& S.A.; Banamex; Bank of Montreal; Cana- } \\
\text { dian Bank of Commerce; The Bank of Tokyo LTD.; Credit Lyonnais; } \\
\text { Deutsche Bank; The Long-Therm Credit of Japan LTD.; The Mit- } \\
\text { subishi Bank LTD.; The Tokai Bank Limited; The Bank of Nova Sco- } \\
\text { tia; Barclays Bank Int. LTD.; Societé Generale; Morgan Guaranty } \\
\text { Int. Bank; Westdeustsche Landesbank Girozentrale. } \\
\text { Rosenthal International. }\end{array}$ & $\begin{array}{r}4000.00 \\
50\end{array}$ & $\begin{array}{c}\text { n.d. } \\
1 / 2\end{array}$ & $\begin{array}{l}\text { n.d. } \\
1 / 2\end{array}$ \\
\hline
\end{tabular}




\begin{tabular}{|c|c|c|c|c|}
\hline Fecha & Instituciones financieras prestatarias & $\begin{array}{l}\text { Monto en } \\
\text { millones }\end{array}$ & Años & $\begin{array}{c}\text { Interés } \\
\text { (Porcentaje) }\end{array}$ \\
\hline Noviembre. & $\begin{array}{l}\text { Manufactures Hannover Limited; Credit Commercial de France } \\
\text { (Lead); Algemene Bank Nederland; Bank of America International; } \\
\text { Banque Bruxelles Lambert; Country Bank; Lyonnais; Daiwa Europe; } \\
\text { IBJ International; International Mexican Bank; Kreduetbank Inter- } \\
\text { national Group; Lloyds Bank International; Merrill Lynch Interna- } \\
\text { tional; Societé Generale; Societé Generale de Banque. } \\
\text { Banco Nacional de Comercio Exterior, S. A.; West LB; Goldman } \\
\text { Sachs International (Lead); Algemene Bank Nederland; Bank Brus- } \\
\text { sel Lambert; Bank of Tokyo International; Banque National de Pa- } \\
\text { ris; Girozentrale and Bank der Osterreichischen Sparksassen; LICB } \\
\text { International; Manufactures Hannover Limited; Nacional Financie- } \\
\text { ra; Orion Royal Bank; Suenska Handelsbanken. } \\
\text { Swiss Bank Corporation International; Algemene Bank Nederland; } \\
\text { Bank of America International Limited; Bank Brussel Lambert; Ci- } \\
\text { ticorp International Bank Limited; Credit Commercial de France; Cre- } \\
\text { dit Lyonnais; County Bank; Credit Swisse Firt Oston; Daiwa Europe; } \\
\text { Deutsche Bank; Goldman Seach International; LTCB International; } \\
\text { Manufactures Hannover Limited; Merril Lynch International; Mor- } \\
\text { gan Guaranty Limited; Orion Royal Bank; Salomon Brother Inter- }\end{array}$ & 125 & 9 & $1 / 4$ \\
\hline TOTAL & 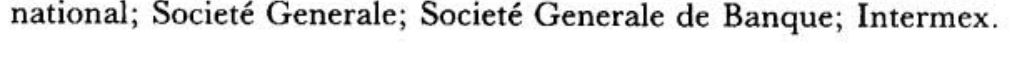 & $\begin{array}{r}75 \\
4300\end{array}$ & 5 & 17 \\
\hline
\end{tabular}


Continúa CUADRO 17

\begin{tabular}{llrrr}
\hline \multicolumn{1}{c}{ Fecha } & \multicolumn{1}{c}{ Instituciones financieras prestatarias } & $\begin{array}{c}\text { Monto en } \\
\text { millones }\end{array}$ & $\begin{array}{c}\text { Años } \\
\text { (Porcentaje) }\end{array}$ \\
\hline Enero & Commerzbank; Deutsche Bank; West LB; Credit Lyonnais; DG Bank; & & & \\
& Manufactures Hannover Limited; Merrill Lynch International; Swiss & & & \\
& Bank Corporation Int.; Daiwa Europe; Lloyds Bank International. & 150 & & \\
Enero & Europe Banking Company & 200 & 6 & $1 / 8$ \\
& n.d. & 2000 & n.d. & n.d. \\
TOTAL & & 262.1 & & \\
& & & & \\
\hline
\end{tabular}

FUENTE: World Bank. Borrowing in International Capital Markets, Washington, varios números. 
CUADRO 18
CRONOLOGÍA DE LAS RENEGOCIACIONES DE LA DEUDA EXTERNA 1982-1987

\begin{tabular}{llll}
\hline Fecha & Concepto & $\begin{array}{l}\text { Millones } \\
\text { de dólares }\end{array}$ & Caracteristicas \\
\hline
\end{tabular}

Agosto Plan de Salvamento 1800 Participaron el Banco de pagos internacionales

de 1982

$\begin{array}{ll}\text { Diciembre } & \text { Primera } \\ \text { de } 1982 & \text { Restructuración }\end{array}$

$\begin{array}{ll}\begin{array}{l}\text { Diciembre } \\ \text { de } 1983\end{array} & \text { Nuevo Crédito } \\ \begin{array}{l}\text { Junio } \\ \text { de } 1983\end{array} & \begin{array}{l}\text { Club de París } \\ \text { (Deuda privada }\end{array} \\ \begin{array}{l}\text { Octubre } \\ \text { de } 1983\end{array} & \text { Ficorca } \\ \begin{array}{l}\text { Abril } \\ \text { de } 1984\end{array} & \text { Nuevo Crédito } \\ \begin{array}{l}\text { Septiembre } \\ \text { de } 1984\end{array} & \begin{array}{l}\text { Segunda } \\ \text { Restructuración }\end{array}\end{array}$

Marzo Tercera

de 1987 Restructuración de Suiza. El $50 \%$ fue provisto por la Reserva Federal de Estados Unidos.

1000 Pago anticipado del gobierno de Estados Unidos por compra de petróleo para la reserva estratégica del Pentágono.

300 Pago anticipado por envío de petróleo a España.

1000 Financiamientos agrícolas de la Comodity Credit Corporation

23000 Vencimientos entre agosto de 1982 y diciembre de 1984. Plazo 4 años de gracia y 8 años para pagar. Costo $13 / 4 \%$ sobre prime rate $y$ $17 / 8$ sobre libor. Comisión $1 \%$.

3900 Crédito otorgado por el FMI (Facilidad Ampliada de Fondos) Aportaciones trimestrales durante un periodo de 3 años.

5000 Otorgado por 530 bancos con 3 años de gracia y 6 años de plazo. Costo de $21 / 8$ sobre prime

1500 rate y $21 / 4$ sobre Libor. Comisión de 1 1/4\%.

$y$

2000

12000 Con 3 años de gracia y 6 años de plazo

3800 Con 5 años 6 meses de gracia y 10 años de plazo. Con un costo de $11 / 8$ sobre prime rate y 1 1/2 sobre libor. Cornisión de 5/8\%.

48000 Incluye 23000 millones restructurados y 20000 millones con vencimiento entre 1985 y 1990. El plazo es de 7 años de gracia y 14 años de plazo. Elimina prime rate; $7 / 8$ sobre Libor durante los 2 primeros años; 1 1/8 en los 5 años intermedios; 1 1/4 en los 7 últimos; en promedio $1.11 \%$.

Incluye 500 del crédito fresco otorgado en febrero de 1983 con 5 años de gracia y 10 años de plazo. Costo de 1 1/2 sobre Libor y 1 1/8 sobre prime rate.

75250 Incluye 43.700 millones de la deuda externa pública de 60000 y 9500 de Ficorca; los créditos otorgados de 5000 en 1983 , el de 3800 otorgado en 1984 y el de 1800 otorgado por el Club de Paris (Deuda Privada). Con vencimiento de 7 años de gracia y 20 años de plazo.

6000 Incluye 1700 del FMI (1 200 si se reduce el barril por abajo de los 9 dólares y 500 si la tasa de crecimiento es menor al $3 \%$ en el primer trimestre de 1987). De los acreedores multilaterales $2: 00$ y de los bilaterales 1800 .

6000 De créditos otorgados por la banca comercial facilidad 1:5000 y facilidad 2:1000. Japón participa con 500 millones de dólares para el proyecto petrolero del Pacífico; 250 Programa de Desarrollo de las Exportaciones. Estos a 6.1\% en yenes y los tres proyectos a plazo de 15 años. Otros 250 millones tendrían el mismo plazo pero 1.12 a 1 13/16. 


\section{DEUDA Y PROYECTO NEOLIBERAL}

En el marco de la crisis internacional del capitalismo las alternativas y soluciones presentadas al problema de la deuda externa de los países del Tercer Mundo, de América Latina y de México, han ocasionado transferencias reales de recursos hacia los países acreedores logrando una reestructuración en el proceso de acumulación de capital a nivel nacional, a partir de la llamada crisis de liquidez de 1982.

El presente capítulo muestra el resultado de las alternativas presentadas al problema del servicio de la deuda externa en México. Las continuas renegociaciones y la firma de dos acuerdos con el Fondo Monetario Internacional (FMI) han desarrollado, a lo largo de un sexenio, un cambio estructural en el proceso de acumulación interno. Tan es así que el ajuste ha permitido la transferencia real de recursos por más de 50 mil millones de dólares, monto similar al promedio del $7 \%$ del Producto Nacional Bruto. ${ }^{1}$

El lenguaje necesario de "saneamiento de las finanzas públicas" y "mejorar el perfil de endeudamiento" toman forma a través de las Cartas de Intención y de los Acuerdos firmados por México con el FMI. Sin embargo, hacen suyo un discurso propio de planes nacionales como el Programa Inmediato de Reordenación Económica (PIRE), el Plan Nacional de Desarrollo 1982-1988 (PND), el Programa de Aliento y Crecimiento (PAC) y el Pacto de Solidaridad Económica (PSE).

${ }^{1}$ Ruiz Durán, Clemente. "México: The transfer problem. Profits and welfare", en Financing Latin American growth prospects for the 1990s', 13-15 de octubre de 1988, Jerome Levy Economics Institute. Annandale -on- Hudson, New York. 
En este capítulo realizamos un resumen de las políticas de ajuste y de la deuda externa; en el inciso tercero analizamos la crisis y el ejercicio del proyecto neoliberal en México; además, incluimos también las características de los Acuerdos de Facilidad Ampliada del FMI en el país; más adelante, se muestran las características de las renegociaciones llevadas a cabo por México ante la comunidad financiera internacional y, por último, presentamos las alternativas en que el gobierno mexicano ha participado y ha presentado a sus acreedores para solucionar el servicio de la deuda externa.

\section{Políticas de ajuste y pago de la deuda externa}

Uno de los aspectos más discutidos de la política económica del periodo de la crisis de liquidez al desfinanciamiento del país, fue el conjunto de alternativas presentadas por el gobierno mexicano para ofrecer soluciones adecuadas al tratamiento de la deuda externa.

Este periodo, identificado en capítulos anteriores como de la crisis de liquidez al desfinanciamiento, se caracteriza por una secuencia de renegociaciones de la deuda externa y por la supeditación de la política económica a los planes de ajuste del FMI. En consecuencia, hay un cambio estructural en la economía mexicana, acompañado de una apertura comercial, de una reorganización industrial, de una mayor inflación con recesión, de fuga de capitales, de aumento de deuda externa y de disminución de las divisas petroleras.

Es necesario recordar que la canalización del endeudamiento externo, durante el boom petrolero, fue utilizada precisamente para expandir la inversión del gobierno federal que agudizó los impactos del proceso de internacionalización del capital, vía el capital productivo, capital dinero y capital mercantil. Dentro de dicha dinámica, el capital dinero irrumpió en la economía mexicana canalizando la mayor parte del endeudamiento al petróleo y amplió, de manera indirecta, todas aquellas ramas conexas a éste, permitiendo además la expansión del sector privado. Cuando se presenta la caída permanente del precio 
del petróleo a nivel internacional se comprueba el error de haber canalizado gran parte del financiamiento externo a un bien necesario en el proceso de acumulación internacional. Condicionando así las variables de la economía nacional a dicho proceso y a la petrolización. ${ }^{2}$

Por ello, y como uno de los objetivos prioritarios de la política económica, se propuso promover las exportaciones para lograr las divisas necesarias y así enfrentar el servicio de la deuda externa. ${ }^{3}$ Las exportaciones mexicanas sufrieron un cambio estructural, reforzando la integración silenciosa de la frontera norte con Estados Unidos, vía las maquiladoras, y afianzando la penetración de la inversión extranjera en las industrias de punta y de exportación. Así, la débil respuesta al problema de la deuda externa y la apertura comercial y una mayor facilidad a la inversión extranjera, mermarían la soberanía nacional y alinearían al país, cada vez más, con los intereses de la política exterior de Estados Unidos. ${ }^{4}$ Como se señaló anteriormente, este proceso constituirá un cambio estructural para lograr las divisas necesarias y así satisfacer el servicio de la deuda externa. Tan sólo el pago de la deuda externa representó el $55.1 \%$ del presupuesto de egresos de la federación para 1987, tendencia que durante el periodo

${ }^{2}$ El precio del petróleo disminuyó $16 \%$ entre diciembre de 1982 y diciembre de 1985. Se suponía que el precio promedio del crudo durante el año 1986 sería 23 dólares por barril, $9.3 \%$ inferior al de 1985 . Sin embargo, el precio promedio del crudo mexicano fue de ocho dólares por barril durante 1986; es decir, 11.8 dólares por barril, $46.6 \%$ del nivel promedio que tuvo en 1985. En 1987, el precio promedio del petróleo crudo de exportación tuvo un incremento de $35 \%$ en relación a 1986; el precio tuvo un promedio de 16.4 dólares en el año (4.20 dólares más que en 1986). Cf. Varios números de Informes del Banco de México. ${ }^{3} \mathrm{La}$ exportación petrolera que en 1983 representaba el $76 \%$ de las ventas totales, disminuyó a $40 \%$ en 1986 y aunque se incrementó su participación por el aumento del precio del petróleo, los productos industriales pasaron del 19\% en 1983 al $49 \%$ de las ventas totales del país en 1986 . El porcentaje persistió en 1987 y la exportación de manufacturas fue de $48 \%$. Cf. El Mercado de Valores, año XLVII, núm. 15, 13 de abril de 1987.

${ }^{4}$ La posición de México frente a sus vecinos del sur se modificó con la crisis financiera. A pesar de la presencia mexicana en el Grupo Contadora la ingerencia de Estados Unidos no fue contrarrestada por la política exterior de nuestro país. 
1982-1988 subsistió a pesar de los ingresos por exportación y de la política recesiva del gobierno.

El pueblo, por su parte, empieza a ver con pesimismo el deterioro de su salario. Si se toma como índice 1976 igual a 100 resulta que el salario nominal tuvo un incremento de $5410.9 \%$ y un decremento real de $52.8 \%$ a 1987.5

El efecto de la baja de los precios internacionales del petróleo y el esfuerzo de México en el proceso de modernización y reordenación mostraron un balance negativo. Ello significaba que en sólo 12 meses (1986) se perdieron 8500 millones de dólares por exportaciones de petróleo, igual a $6.5 \%$ del PIB; dejaron de ingresar casi dos mil millones de dólares por la caída de los precios del resto de las materias primas; el sector privado amortizó deudas por 1250 millones de dólares; el crédito externo neto al sector público fue inexistente y se pagaron más de ocho mil millones de dólares de intereses sobre la deuda. Este verdadero cataclismo de origen externo ocurrió a escasos meses de los terremotos de septiembre de 1985, que tantos daños causaron y después de tres años de enormes esfuerzos de reordenación interna. ${ }^{6}$ En el periodo 1980-1987 México ha otorgado como tributo a sus acreedores la cifra de 67500 millones de dólares; es decir, un promedio de más de ocho mil millones de dólares anuales. ${ }^{7}$

\section{Crisis y proyecto neoliberal}

La situación económica del país se deslizó progresiva e incesantemente hacia una crisis durante todo el transcurso de 1982. Desde principios de la década de los años ochenta el ritmo de la actividad industrial comenzó a desacelerarse y a mediados de 1982 se podía observar una caída en la tasa

\footnotetext{
${ }^{5}$ CEPAL. Notas para el Estudio Económico de América Latina y El Caribe. 1987. Separata, 1 de julio de 1988. LC MEX/L. 82

${ }^{6}$ Salinas de Gortari, Carlos. "Modernización y cambio estructural, divisa de nuestro tiempo", en Comercio Exterior, vol. 37, núm 2, México, febrero de 1987, pp. 157-159.

${ }^{7}$ CEPAL. Op. cit.
} 
de crecimiento que tendía a hacerla negativa. Las medidas de política económica incitaron un descenso de la demanda y las políticas cambiarias estimularon la escasez de insumos de importación que incidieron sobre la producción. ${ }^{8}$

Desde 1932 México no había sufrido una caída del producto bruto real y la más elevada inflación que conocía había llegado al $45 \%$ en el año de 1944 .

Además de las dificultades ocasionadas en 1982 por la caída en el producto y el elevado ritmo de la inflación, las relaciones comerciales y financieras de México con el exterior se deterioraron seria y progresivamente durante dicho año. En los últimos meses, el crédito externo llegó a interrumpirse, casi todas las empresas del sector privado suspendieron el servicio de sus deudas con el exterior, y las reservas de divisas del banco central del país prácticamente se agotaron. ${ }^{9}$

El tipo de cambio, en los mercados libre y controlado, se depreció en ese año $466.2 \%$ y $268.0 \%$ respectivamente, mientras la inflación se hacía incontenible, completándose el año con una tasa del 98.8 por ciento.

Así, en 1982 se inició la crisis económica más grave de nuestra historia reciente. El país tenía que afrontar la carga asfixiante de una deuda externa de 91552 millones de dólares, sin contar con los recursos necesarios para hacerlo y con una fuerte dolarización y fuga de capitales. La magnitud del déficit público no tenía precedente y el resultado fue el crecimiento desbocado de la inflación. Existía temor de que se produjera una ola de quiebras con consecuencias gravísimas para el aparato productivo y el empleo. Pero aún se vivía un ambiente de resentimiento y desconfianza. Las recriminaciones que se hacían entre sí los diversos sectores llegaron a sugerir la ruptura de los acuerdos básicos que nos conforman como nación. ${ }^{10}$

El 22 de agosto de ese año fatídico, la administración mexicana acudió a la comunidad bancaria internacional solicitando

${ }^{8}$ En el capítulo 2 se evaluó la crisis de México en relación con la política de endeudamiento. Allí apuntamos algunos elementos en función de la crisis, la política de ajuste y la implementación del proyecto neoliberal.

${ }^{9}$ Banco de México. Informe Anual 1982. México, 1983.

10 Ibid. 
una prórroga de 90 días para los pagos de capital, correspondientes a la deuda del sector publico. ${ }^{11} \mathrm{Al}$ mismo tiempo, se concertaban los contratos previos con el FMI, al que el país solicitaba disponer de los recursos que le correspondían como miembro. Este reclamo venía acompañado de un esquema de refinanciamiento de una deuda del sector público con la banca comercial, similar a 23 mil millones de dólares, con vencimientos que se prolongaban hasta diciembre de 1984. En ese documento, el gobierno saliente se comprometía a reducir el déficit del sector público, a dar elasticidad a los instrumentos cambiarios y a las tasas de interés con una limitación en el uso de recursos externos a un monto no mayor de cinco mil millones de dólares, a flexibilizar el manejo de los precios controlados y a revisar el sistema de protección arancelaria. ${ }^{12}$

La magnitud de la crisis mexicana a fines de 1982 se resume con algunos indicadores frecuentemente utilizados para definir políticas de ajuste donde se incluye su evolución en años precedentes. Durante el periodo de 1978-1981 correspondiente al auge petrolero, México experimentó tasas de crecimiento notables. El PIB aumentó desmesuradamente de $6.9 \%$ en 1970 a $5.6 \%$ en $1975 ; 8.3 \%$ y $7.9 \%$ en 1980 y 1982 , respectivamente. Para bajar a $-5.2 \%$ en 1982 . También el déficit público, en relación con el PIB, pasó de $7.5 \%$ en 1980 a $14.4 \%$ en 1981 y $17.6 \%$ en 1982 . La balanza en cuenta corriente tuvo un déficit de 12544.3 millones de dólares en 1981 y ese año se pagaron 13700 millones de dólares por concepto del servicio de la deuda externa.

El servicio de la deuda externa, en relación con las exportaciones, fue de $40 \%$ en 1980 , de $23 \%$ en 1981 y de $75 \%$ en 1982. Por tanto, no sorprende que como resultado de problemas internos acumulados y la caída de los precios del pe-

\footnotetext{
${ }^{11}$ Cf. Excelsior, Business Week, News Week, y The Washington Post, los que calificaron, en su momento, a la moratoria mexicana y a las medidas tomadas como el verano más caliente de la historia financiera internacional (hot summer).

${ }^{12}$ Nacional Financiera. "Carta de Intención de México al FMI", En El Mercado de Valores, añe XLII, núm 47, 22 de noviembre de 1982.
} 
tróleo, así como las alzas y restricciones en el crédito internacional, México se sumiera en un largo y profundo periodo recesivo a partir de 1982. Cabe apuntar que las tasas de interés alcanzaron un desorbitado nivel de $18.36 \%$ en el tercer semestre de $1981 .{ }^{13}$ En ese año, el peso se devaluó tres veces. De una tasa de cambio de 26.61 pesos por dólar en enero, pasó a 150 pesos por dólar en diciembre. La inflación llegó a un nivel histórico pico de $98.8 \%$ y el PIB decreció 0.5 por ciento.

Ante tal situación, el FMI y el gobierno mexicano acordaron que se produjera el traspaso de mando a la nueva administración bajo los lineamientos de la firma del acuerdo de estabilización. La nueva administración encontraría pavimentada la ruta hacia la consolidación del cambio estructural de un modelo populista a uno trasnacional, bajo la hegemonía del proyecto neoliberal, proceso contradictorio a los intereses de las clases populares. Hecho cíclico que se repetirá a finales del sexenio 1982-1988 y cuyas características similares se prolongarán hasta el periodo siguiente con el préstamo puente por dos mil millones de dólares, otorgado a finales del gobierno de Miguel de la Madrid. ${ }^{14}$

Los resultados, sin embargo, fueron diferentes. La negociación no tuvo la firmeza requerida y el servicio de la deuda externa no fue el resultado de la capacidad de pago del país. La pérdida de recursos para dar servicio al equivalente general impidieron el desarrollo de obras de infraestructura y de un mayor crecimiento del país. El discurso del Ejecutivo, resultado de la aplicación del proyecto neoliberal, fue adquiriendo una tónica de supeditación de la política económica

${ }^{13}$ Ortiz, Edgar. "Crisis y deuda externa: limitaciones de las políticas de estabilización y alternativas para el desarrollo y la renegociación del endeudamiento". Ponencia en el Congreso de Economistas de Oaxaca, Oax., 1987. Véase también del mismo autor: "Deuda externa, estabilización y cambio estructural: inviabilidad y solución política global, el Caso de México"'. Ponencia en el I Foro sobre Deuda externa y soberanía nacional, México, agosto de 1986.

${ }^{14}$ De la Madrid Hurtado, Miguel. Sexto Informe de Gobierno. Secretaría de la Presidencia, México 1988. Iniciado el nuevo gobierno se dijo que dicha línea de crédito no se había utilizado pero que, si fuese necesario, el gobierno de Salinas de Gortari tomaría en cuenta los recursos. 
a los acreedores de México, sin poner en tela de juicio el principio de corresponsabilidad. El desastre ocasionado por el terremoto en la ciudad de México en 1985 y los efectos inmediatos del huracán "Gilberto" no fueron incentivos para alentar al gobierno a tomar una posición diferente. Incluso, al final de su mandato, el Ejecutivo afirmó

que si hubiéramos declarado la moratoria habríase elevado el nivel de vida, pero es inexacto. De ordenar la suspensión de pagos se hubiera originado un conflicto económico internacional [...] era una medida populista, teóricamente avanzada, y nos habría durado poco la popularidad. Es preciso el manejo sensato de la economía. Recordemos esa experiencia y veamos que la moratoria no le permitió al gobierno de México gastar más en desarrollo social. Al contrario tuvo que ajustar más. Esa es nuestra experiencia concreta, no hay que ir a otras partes para verla y si observamos las moratorias unilaterales declaradas por otras naciones vemos que las consecuencias que están pagando son muy graves y que ya no solamente influyen en el terreno económico, sino que tiene graves repercusiones sociales y alientan las políticas de desestabilización. ${ }^{15}$

La firma de los Acuerdos de Estabilización con el FMI y las renegociaciones de la deuda externa serían las alternativas y soluciones al problema del endeudamiento para enfrentar el pago de la deuda externa. De alguna manera reafirmaban la postura mantenida por el Ejecutivo cuando señalaba que " "...nuestros costos son los más bajos del mundo. Así que tenemos margen para seguir exportando con ganancia.."..16 En pocas palabras, señalaba la contención o virtual congelación de salarios que permitiría el flujo de una concentración del ingreso mayor, un servicio de la deuda externa sin intercepciones y una mayor integración con el proceso de acumulación internacional. Todo ello, en el marco del ajuste ejercido por el proyecto neoliberal.

Las alternativas de solución a la deuda externa de México, consideradas por el gobierno en su política económica, han ${ }^{15}$ Excélsior, México, 26 de noviembre de 1988. Entrevista con Regino Díaz Redondo.

16 Ibid. 
sido de antemano pactadas con el FMI y han evolucionado considerablemente desde que se presentó la crisis en 1982. Por ello es necesario analizar el Convenio de Facilidad Ampliada, firmado en diciembre de 1982 con vigencia de 1983 a 1985 y el Convenio de Crédito Contingente, firmado en junio de 1986 con duración de 18 meses. El primer convenio influyó en el PIRE y el PND 1983-1988. El segundo en el PAC. El PSE, iniciado a finales de diciembre de 1987 y el transcurso de 1988, es un plan que, al igual que los anteriores, vino a ejemplificar el proyecto neoliberal en un programa recesivo cuyo objetivo sería abatir la inflación sin dejar de seguir pagando el servicio de la deuda externa.

\section{Características de los acuerdos del FMI}

Primer Acuerdo de Facilidad Ampliada: 1983-198517

Antecedentes del primer convenio. Recordar ahora algunas acotaciones de quien estuvo a cargo de la firma del primer Convenio de Facilidad Ampliada en 1982 es manifestar los antecedentes verticales de toda una política de ajuste, implementada por factores externos e internos.

Desde el mes de abril de 1982 se planteó en México la posibilidad de suscribir un convenio de apoyo financiero con el FMI. Sin embargo, no fue hasta el mes de agosto del mismo año cuando, a raíz del establecimiento de la doble paridad y la fuerte devaluación del peso frente al dólar, finalmente se iniciaron las pláticas formales. ${ }^{18}$

La moratoria realizada por el gobierno mexicano frente a la comunidad internacional movilizó al Departamento del Tesoro de Estados Unidos para lograr una concertación en-

${ }^{17}$ El 10 de noviembre se firmó la carta donde el gobierno mexicano solicitaba acceso a los recursos financieros del FMI a los que México tenía derecho. El 23 de diciembre de 1982 el director ejecutivo del FMI aprobó la solicitud hecha por México. Cf. Tello Macías, Carlos. La Nacionalización de la Banca en México. Siglo XXI Editores, México, 1984 y Comercio Exterior, enero de 1983.

18 Tello Macías, Carlos. Op. cit.. 
tre la banca trasnacional y la banca multilateral con el objeto de otorgar un "plan de rescate" momentáneo para evitar el colapso del sistema financiero internacional y otorgar a México cierta liquidez, pues muchos la interpretaron como crisis de liquidez. Por ello, el objetivo de la firma del Convenio era obtener de manera rápida los 3900 millones de dólares y resolver momentáneamente sus necesidades de divisas indispensables para sus importaciones.

La ronda inicial de 1982-1983 de planes de financiamiento bancarios suponía de inmediato "dinero nuevo" o "crédito concertado", (es decir, aumentos equiproporcionales en la exposición crediticia coordinados por un comité de asesoría bancaria) en forma de financiamiento para fines generales para los gobiernos centrales y, de acuerdos de reestructuración que transformaran deuda del sector privado, a menudo oficialmente garantizada, en deuda directa del sector público. Las condiciones de estos préstamos reflejarían la percepción de que las dificultades del servicio de la deuda del país deudor eran temporales; los periodos de consolidación durante los cuales se verificó la reprogramación, abarcaron solamente uno o dos años, los vencimientos para la deuda reprogramada iban hasta a 10 años, y los márgenes fueron aumentados típicamente en un 2 al $2.25 \%$ por encima del tipo interbancario de oferta de Londres (Libor). ${ }^{19}$

Metas fundamentales de la primera Carta de Intención. ${ }^{20}$ Los principales planteamientos de la primera Carta de Intención firmada por México con el FMI pueden resumirse de la siguiente manera: en primer lugar, la corrección del déficit del sector público; en segundo, se intensificaría la reducción del gasto público eliminando los programas no prioritarios y los gastos corrientes vinculados a ellos. Como tercer punto, las tasas de interés tendrían como fin estimular el ahorro y se fomentaría el desarrollo del mercado de valores, para vincular directamente a los ahorradores con el proceso de for-

${ }^{19}$ Bailey, Norman A. y Richard Cohen. La Bomba de Tiempo Mexicana. Un ensayo de la Twentieth Century Fund, Editorial Grijalbo, México, 1987.

${ }^{20}$ La carta se dirigió a Jaques de Larosière, director del FMI y se fechó el 10 de noviembre de 1982. Cf. El Mercado de Valores, año XLVII, núm 47, noviembre de 1982. 
mación de capital. En cuarto lugar se racionalizarían los subsidios. En quinto, la política cambiaria sería flexible y en la franja fronteriza y zonas libres el tipo de cambio se fijaría de acuerdo con la oferta y demanda. En sexto lugar la libertad de comercio hacia el exterior propiciaría una mayor integración del aparato industrial con el fin de hacerlo más eficiente.

Estos planteamientos contenidos en la carta firmada por el gobierno saliente y llevada a cabo por la nueva administración serían elemento clave para entender, seis años después, lo ocurrido con la economía mexicana. En dicha carta se discierne con cierta dificultad el proyecto neoliberal de la economía mexicana, de modo que ni los mismos miembros del partido gubernamental se percatarían plenamente del cambio radical y estructural que sufriría el país. Por ejemplo, un hecho que pasaría inadvertido es el anuncio del desarrollo del mercado de valores, pues este cobrará gran vigor a finales de 1985 y una mayor participación del pequeño y mediano inversionista en 1987. Sin embargo, se puede ver entre líneas que la vinculación de los ahorradores con el proceso productivo traería un incremento inusitado de la Bolsa de Valores; más que un reflejo de la actividad productiva real del país, sería una fuente especulativa, especialmente en el último trimestre de 1987. Asimismo, este crecimiento explosivo de la Bolsa desplaza a la "banca nacionalizada" del mando de participar en el sector productivo, regresando el control a los antiguos dueños a través de su participación en las Casas de Bolsa (que se reprivatizan), mediante la canalización de recursos de estas instituciones a las empresas de propiedad de la facción capitalista financiera. En 1990 la banca se privatizaría por Decreto Oficial.

En relación con el tipo de cambio, el objetivo será subsidiar al inversionista privado para obtener dólares a través del tipo de cambio controlado en un principio, pero al final propiciará un mercado libre cambiario regulado por la oferta y demanda de divisas estadounidenses. 
Objetivos de la segunda Carta de Intención. ${ }^{21}$ En la segunda Carta de Intención se estableció un programa de ajuste mucho más drástico. Sus objetivos eran corregir los desequilibrios externos fortaleciendo las finanzas públicas y el ahorro interno para lograr el crecimiento sostenido de la producción y el empleo: a) Se elevaron las tasas de interés para promover el crecimiento del ahorro interno. b) Se racionalizaron los controles de precios. c) La política salarial se orientó al objetivo de proteger el nivel de empleo. d) Se adoptó una política cambiaria para lograr una mayor competitividad de la economía y aumentar la disponibilidad de divisas y se eliminaron los subsidios cambiarios. e) La negociación de la deuda externa fue fundamental para mejorar el perfil de endeudamiento y se creó un mecanismo, el Fideicomiso de Cobertura de Riesgo Cambiario (Ficorca), que permitió absorber pérdidas durante el plazo de la reestructuración de la deuda.

Así, en la segunda Carta de Intención enviada al FMI se señalaban los éxitos del PIRE señalando que entre una de sus metas había estado el restablecimiento de la confianza del gran capital, pues sostiene que

busca efectuar importantes cambios estructurales en la economía y la sociedad mexicanas para que el ingreso nacional se distribuya de manera más equitativa entre la población; para que los desequilibrios sociales se reduzcan; para que las instituciones democráticas y la soberanía nacional se fortalezcan; y para que la libertad y la justicia rijan en nuestro proceso de desarrollo. ${ }^{22}$

Después, a los cinco años, se hizo notable todo lo contrario. La fuerte reducción en las importaciones y la competitividad, alcanzada bajo la subvaluación del peso mexicano, logró que por primera vez en la historia la balanza comercial registrase un superávit de 12 mil millones de dólares resultado de la fuerte contracción de las importaciones. ${ }^{23}$

\footnotetext{
${ }^{21}$ El Mercado de Valores, año XLIV, núm 2, 9 de enero de 1984.

${ }^{22}$ Ibid.

${ }^{23}$ Ibid. p. 28. Punto 10.
} 
México estuvo negociando la reestructuración de la deuda externa privada, garantizada por organismos oficiales de los principales socios comerciales del país. Durante 1983 se pagó un total de 1100 millones de dólares de adeudos atrasados. Al mismo tiempo, se buscó que los acreedores extranjeros reestructurasen la deuda externa del sector privado a través del mecanismo de Ficorca, lo que permitió reestructurar la mayor parte de dicha deuda sin que el sector público asumiera el riesgo comercial. A fines de octubre de 1983 los deudores nacionales habían registrado 11600 millones de dólares en el Ficorca. ${ }^{24}$

Objetivos de la tercera Carta de Intención. ${ }^{25}$ En el marco de la política llevada a cabo bajo los lineamientos del PIRE y el PND, la economía mexicana, desde el punto de vista del equipo gobernante, había tenido gran éxito. Los índices reflejaban un descenso en la inflación de $100 \%$ en 1982 a $59.2 \%$ en 1984; la reducción del déficit del sector público de $17 \%$ a $6.2 \%$ del PIB en 1984. En relación a la balanza de pagos la cuenta comercial arrojó, en 1984, un superávit de $13000 \mathrm{mi}-$ llones de dólares y la cuenta corriente un superávit de cuatro mil millones de dólares. Los resultados anteriores permitieron un incremento en las reservas netas de divisas del Banco de México del orden de tres mil millones de dólares; el crecimiento de la economía pasó de una cifra de menos $5.7 \%$ en 1983, a más de 3.5\% en 1984.

La Comisión Económica para América Latina (CEPAL) indicaba que durante 1985, la política económica en México se debatió entre dos objetivos que no se lograron conciliar: por una parte, reactivar la producción y el empleo para atender las demandas económicas y sociales insatisfechas de una

\footnotetext{
${ }^{24}$ Ibid. p. 29. Punto 12.

${ }^{25}$ Nacional Financiera. "Carta de Intención del Gobierno de México al FMI", en El Mercado de Valores, año XLV, núm. 13, 1 de abril de 1985. El 24 de marzo las autoridades financieras mexicanas enviaron a Jacques de Larosiere, la carta de intención que corresponde al tercer y último año de vigencia del Acuerdo de Facilidad Ampliada, establecido en noviembre de 1982.
} 
población creciente y, por otra, continuar el proceso de ajuste para controlar los grandes desequilibrios que hicieron crisis en 1982. ${ }^{26}$ Fueron los factores externos los que incidieron en una disminución de las divisas que propiciaron profundamente el recorte presupuestal severó e incitaron a una devaluación en julio y a un mayor deslizamiento de la moneda. Destacan las elevadas tasas de interés en el mercado internacional de capitales; éstas originaron pagos por 10 mil millones de dólares. El deterioro de los precios del petróleo y la suspensión de compras de gas de Estados Unidos, se tradujeron en una merma de ingresos de divisas de casi dos mil millones de dólares. ${ }^{27}$

La reactivación económica de algunos indicadores económicos durante 1984 fue momentánea. En 1985 la caída del PIB estuvo acompañada del decremento de la inversión pública al contraerse en $3 \%$. Se liquidaron algunas empresas estatales y otras se vendieron; la enorme carga que representó el pago de los intereses de la deuda por 10 mil millones de dólares sumaron una relación comercial desventajosa con el exterior y una severa limitación para acceder al crédito internacional. A tal grado que se tuvo que posponer el pago de las amortizaciones de la deuda externa y echar mano de las reservas monetarias internacionales, que se redujeron a 2400 millones de dólares. El servicio de la deuda absorbió un monto sustancial de los ingresos de divisas por exportaciones $(47 \%$ en 1985$){ }^{28}$

La deuda externa del sector público ascendió a $72100 \mathrm{mi}$ llones de dólares (2 700 millones más que en 1984), no tanto por nuevos flujos (390 millones), sino por efecto del registro de pasivos asumidos por el gobierno y por la revaluación, en términos de dólares, de los préstamos expresados en otras monedas. La deuda externa total del país se elevó a $98 \mathrm{mil} \mathrm{mi-}$ llones de dólares. En términos reales, ésta se contrajo frente

${ }^{26}$ CEPAL. Op. cit.

27 Ibid.

${ }^{28}$ Nacional Financiera. “Carta de Intención...”, en El Mercado..., abril de 1985. 
a los niveles de 1984. Sin embargo, en términos del valor de las exportaciones, el servicio de la deuda aumentó su proporción. ${ }^{29}$ No obstante que se había logrado una reestructuración por 48500 millones de dólares, el problema de la deuda externa no mejoró.

El año de 1985 sería clave para demostrar el fracaso del convenio firmado por México y el FMI. Los hechos que se sucedían durante el año hacían necesaria la disminución de un ajuste tan severo, pues el descontento en las masas urbanas, inclinadas por la participación del Partido Acción Nacional (PAN), el desajuste entre los dirigentes sindicales, obreros y campesinos dentro del Partido Revolucionario Institucional (PRI) y la concientización de la severidad del programa por los mismos dirigentes del gobierno provocaron un desinterés por continuar con dicha política.

Aunados a los factores externos (el aumento de las tasas de interés, la devaluación del peso y la baja de los precios del petróleo), los factores internos, especialmente las medidas de políticà económica ante el dramático terremoto de 1985 , que propiciaron una falta de credibilidad en el gobierno de Miguel de la Madrid que tres años después sería cobrada por la sociedad civil en las elecciones de $1988 .^{30}$

El deudor modelo se asfixiaba. No fue casualidad la presentación del Plan Baker y el inicio de las gestiones protocolarias para que México entrara al Acuerdo General de Aranceles y Comercio (GATT) en noviembre de 1985.

\footnotetext{
29 Ibid.

${ }^{30}$ El resultado de las elecciones del 6 de julio de 1988 otorgó el triunfo al PRI con el $52 \%$ de los votos y reflejó el descontento de la sociedad civil ante el efecto que tuvo el proyecto neoliberal. La política económica encaminada a la racionalización y el ajuste mostró su fracaso.
} 
Segundo Convenio de tipo stand by $y^{31}$

Antecedentes del Segundo Convenio. No sería casual que

la ruptura del consenso que se había alcanzado con el modelo mexicano, junto con la pérdida de influencia de las autoridades monetarias sobre los deudores desempeñaran un papel en la promoción del Plan Baker, que en cierta medida buscaba restaurar un consenso con la moficación de la vieja fórmula. Las autoridades monetarias, guiadas por la Reserva Federal, el FMI y el Banco Mundial aprobaron el Plan Baker en el otoño de 1985, con la Reserva Federal actuando desesperadamente para que lo aceptaran tanto los acreedores privados como los gobiernos deudores. Las reacciones de éstos y aquellos demostraron hasta qué punto se había roto el consenso y cuánta influencia habían perdido las autoridades monetarias. ${ }^{32}$

El Convenio de 1986 sería resultado del fracaso de la política de ajuste que durante tres años había sorteado México bajo el ejercicio del FMI. Desde finales de 1985 y hasta junio de 1986 se iniciaron conversaciones de dirigentes mexicanos con las autoridades del FMI para detallar lo que sería un nuevo Acuerdo de tipo stand by y así permitir que México renegociara su deuda y utilizara los recursos financieros del FMI por el equivalente de 1400 millones de Derechos Especiales de Giro a través de un Convenio Contingente con duración de 18 meses y, al igual que en convenios anteriores, la proposición de dicho Convenio la hizo suya el gobierno mexicano al plasmarla en el PAC.

${ }^{31}$ Secretaría de Hacienda y Crédito Público. "Carta de Intención al FMI", en Comercio Exterior, agosto de 1986, pp. 730-734. El 22 de julio de 1986 el nuevo secretario de Hacienda, Gustavo Petriccioli y el FMI signaron en la Embajada de México en Washington el convenio de tipo stand by. Allí se señalaba que México "requiere utilizar recursos por el equivalente de 1400 millones de DEG a través de un convenio de crédito contingente con duración de 18 meses". Dicho Convenio se enmarcó en los lineamientos del Plan Baker.

${ }^{32}$ Bailey, Norman y Richard Cohen. Op. cit., p. 88. 
Objetivos del Convenio. El objetivo fundamental del programa por 18 meses era restaurar el crecimiento sostenido de la economía en un clima de estabilidad financiera. ${ }^{33}$

¿Cómo sería dicho crecimiento? La misma carta ponía singular acento en el punto 9: El gasto público se ha ajustado drásticamente durante los últimos cuatro años. El gasto público en bienes y servicios no financieros, bajo control presupuestal, declinó a $26.5 \%$ del PIB en 1985 y se proyecta en $24.9 \%$ para 1986 , cuando era de $35 \%$ en 1981 . La inversión pública disminuyó de $8.3 \%$ del PIB en 1981 y se estima en $3.9 \%$ para 1986 , esto equivale a un $55 \%$ de reducción en términos reales. Sin embargo, debido al impacto de la alta inflación sobre las tasas de interés pagaderas sobre la deuda pública interna, el componente de los intereses en el total de los egresos públicos ha subido considerablemente. Como consecuencia, el total de pagos de intereses se incrementó del $5 \%$ del PIB en 1981 a $12.3 \%$ en 1985 y para 1986 se calcula un $18.5 \%$, por lo que existe muy poco margen de maniobra para reducir el gasto del sector público sin que se afecte su capacidad operativa en el corto y largo plazos. ${ }^{34}$

La caracterización del ajuste para 1986 la señalaríamos de nulo crecimiento. El PIB se contrajo $3.8 \%$ y, en términos per cápita, $6 \%$. Este último indicador se situó en niveles equivalentes a los de 1978, anulando el avance que alcanzó durante el "auge petrolero". La baja de la actividad económica fue generalizada, la deuda externa se incrementó en tres mil millones de dólares. De esa suma, cerca de 1400 millones correspondieron al flujo neto de recursos al sector público. En conjunto la banca aumentó su endeudamiento en $700 \mathrm{mi}-$ llones de dólares, mientras que los empréstitos del sector privado disminuyeron en dos mil millones. El resto correspondió a ajustes cambiarios por la revaluación de la deuda expresada en monedas de Europa y Japón. ${ }^{35}$

${ }^{33}$ Nacional Financiera. "Carta de Intención del gobierno de México al FMI", en El Mercado de Valores, año XLVI, núm. 31, 4 de agosto de 1986, p. 751.

${ }^{34}$ CEPAL. Op. cit.

${ }^{35}$ Ibid. p. 28. 
En 1987, al recuperarse el precio del petróleo y el dinamismo de las exportaciones no petroleras, hubo un aumento leve de $1.4 \%$ del PIB pero una contracción de $1 \%$ del PIB per cápita por el aumento demográfico. Los gastos "programables"' se contrajeron $11 \%$, por lo que las finanzas públicas arrojaron un superávit primario de $5 \%$ del PIB, sustancialmente superior al de $1986(1 \%)$. Sin embargo, por efectos del creciente endeudamiento y de la inflación, dicho servicio de la deuda creció $18 \%$ en términos reales y llegó a representar el $45 \%$ de los gastos totales, o sea $20 \%$ del PIB. De esta forma, no se pudo reducir, como se había previsto, el déficit financiero del sector público que se mantuvo en el $16 \%$ del PIB, nivel similar al de $1986 .{ }^{36}$

¿Por qué se presenta como innovador el convenio económico entre México y el FMI? En primer lugar, éste se enmarcó bajo las premisas fundamentales del programa, como el crecimiento sostenido de la economía a tasas de entre 3 y $4 \%$ al año durante el periodo 1987-1988 y la estabilidad. En segundo término, el programa garantiza los recursos externos que requerirá el crecimiento estable, independientemente de posibles fluctuaciones desfavorables del mercado petrolero internacional. En tercero, el Programa ratifica las orientaciones generales de la política económica de aliento a la actividad productiva y de cambio estructural. En cuarto y último lugar, el programa macroeconómico se apega, en la definición de sus metas y mecanismos de seguimiento, a una metodología diferente a la tradicionalmente promovida por el FMI. ${ }^{37}$

En relación al primer punto suponemos que el pago de la deuda externa dejaría de ser una condición exógena determinante de la política económica; por tanto, el crecimiento ocuparía el principio prioritario que regiría la política eco-

\footnotetext{
${ }^{36}$ Nacional Financiera. "Características Innovadoras del Convenio Económico entre México y el FMI', en El Mercado de Valores, año XLVI, núm. 33, agosto de 1986.

${ }^{37}$ CEPAL. Op. cit., p. 3.
} 
nómica. ${ }^{38}$ Este renglón de la economía se logra en el año de 1987 por el incremento en el precio del petróleo. Sin embargo, no se logra vislumbrar una base real en función del aparato industrial pues se destinaría cerca de más del $50 \%$ del gasto del sector público al pago de la deuda externa.

En cuanto al segundo punto, se prevé que si el precio del petróleo baja del nivel de nueve dólares por barril, se establece un mecanismo de financiamiento automático compensatorio.

En relación al tercer punto, nuevamente en este convenio con el FMI el gobierno hace suyo el lenguaje usado con anterioridad en el PAC.

El gobierno ratifica su compromiso de mantener e intensificar la política de cambio estructural, definida desde 1983, particularmente en las áreas de desincorporación de empresas públicas no estratégicas ni prioritarias, reconversión industrial, racionalización de la protección comercial y promoción selectiva de la inversión extranjera.

Por lo que toca al cuarto punto se supone que hay un cambio metodológico de dicho convenio y es que los mecanismos para sanear la economía son de carácter recesivo, porque la economía se debe ajustar internamente para cumplir con dicha meta y su deseo es reducir la inflación. Según el nuevo convenio, se parte de objetivos de crecimiento del PIB para establecer los recursos externos que se requieren y deriva de ello el déficit fiscal real (o déficit operacional) que será compatible con el uso de recursos no inflacionarios disponibles (el déficit financiero total menos el componente inflacionario del servicio de la deuda interna en moneda nacional).

\section{El proceso de renegociaciones}

La prensa especializada de inmediato señaló que el incumplimiento por parte de México con sus acreedores extranjeros podría tener graves repercusiones en el sistema bancario

${ }^{38}$ Nacional Financiera. "Características Innovadoras"... op cit. 
estadounidense. Según una fuente bancaria “...más de las dos terceras partes de la deuda privada pertenecía a bancos estadounidenses y algunos bancos tienen el equivalente de hasta el $90 \%$ de su capital en préstamos a México" ${ }^{39}$ Otra fuente señaló: ".... largo plazo México tiene recursos y la capacidad para hacer frente a los grandes créditos que ha recibido. A corto plazo se ha envuelto en una severa crisis de liquidez que puede ser resuelta si hay buena voluntad de ambas partes". ${ }^{40}$ The Economist indicaba en un artículo titulado "Burro's debt":

el problema político era más agudo, pues con una devaluación del peso del $67 \%$ y una inflación del $100 \%$ México podría estar en una situación semejante de caos a la de Irán o Argentina, tan solo a la puerta del Tío Sam. ${ }^{41}$

De inmediato se llevó a cabo el Plan de Salvamento. Este consistió en un préstamo de 1800 millones de dólares proporcionados por el Banco de Pagos Internacionales de Suiza, de los cuales el $50 \%$ fue provisto por la Reserva Federal de Estados Unidos. Otro préstamo 1000 millones de dólares otorgado como pago anticipado del gobierno de Estados Unidos por compra de petróleo para la reserva federal estratégica del Pentágono. Un pago anticipado de 300 millones de dólares por envío de petróleo a España; 1000 millones de dólares en financiamientos agrícolas de la Comodity Credit Corporation. En síntesis, el gobierno de Estados Unidos aportó cerca de tres mil millones de dólares. Los gobiernos de la Organización de países para la Cooperación y el Desarrollo Económico (OCDE) prometieron a México alrededor de dos mil millones en créditos para exportaciones. ${ }^{42}$

El 10 de diciembre de 1982 se presentó el planteamiento formal a la comunidad bancaria de analizar una reestructura-

39 NACLA. "Mexican Economy", Report, febrero de 1983.

40 The Economist. "The crash of 1982. Banks feel the earth move under their feet', 18 de octubre de 1982.

41 The Economist. "Burros' debt", 21 de agosto de 1982.

${ }^{42}$ Bailey, Norman y Richard Cohen. op. cit. 
ción de los adeudos, lo que, en verdad, significaba posponer los pagos correspondientes a los años de 1982 hasta 1984 por un total de 23 mil millones de dólares (ocho mil de 1982; nueve mil de 1983 y seis mil de 1984). Solicitaban un periodo de gracia de cuatro años y ocho más para escalonar los pagos y un crédito nuevo por cinco mil millones de dólares. Estos fueron los términos de la primera renegociación. Junto con la firma del Acuerdo de Estabilización con el FMI, México empezó a manejar un lenguaje de renegociaciones que se sucederían hasta el presente.

Características de la primera renegociación. A partir de 1983 el lenguaje del equipo económico gobernante otorga a cada renegociación de la deuda externa el carácter de definitiva. No obstante, aunque se incorporen ciertos matices, las famosas reestructuraciones van a sucederse. Al final, se constituyeron en normas; en tanto, ni acreedores ni deudores aspiran a extinguir el adeudo del capital (la pesada carga que acompañó el desarrollo industrial de la nación), las negociaciones se reducen a asegurar su servicio.

Entre las características de la primera renegociación se encuentran las siguientes: ${ }^{43}$

Se reestructuraron 23 mil millones de dólares de pagos de capital de la deuda externa con vencimiento entre el 23 de agosto y el 31 de diciembre de 1984. Las condiciones fueron a un plazo de ocho años, incluyendo cuatro de gracia, con un costo de $13 / 4$ sobre Prime Rate o 1 7/8 sobre Libor; con comisiones de $1 \%$ por una sola vez.

Bajo este esquema se suscribieron 52 contratos de reestructuración de igual número de entidades del sector público, el último de los cuales se firmó en julio de 1984.

En marzo de 1983 se suscribe un crédito con 530 bancos por cinco mil millones de dólares de recursos frescos para satisfacer los requerimientos de divisas en 1983. Las condiciones fueron: un plazo de seis años, incluyendo tres de gracia

${ }^{43}$ SHCP. Notas sobre la restructuración de la deuda externa de México. México, febrero de 1985 . Véase también de la misma SHCP. Deuda externa pública mexicana. FCE., México, 1988. 
con un costo de $21 / 8 \%$ sobre Prime Rate, $21 / 4 \%$ sobre Libor; comisiones de $11 / 4 \%$ por una sola vez.

En junio de 1983, se suscribe un acuerdo con el Club de París para propiciar la reestructuración de entre 1500 y 2000 millones de dólares de deuda privada otorgada y garantizada por organismos oficiales de crédito a la exportación de los países industriales.

En octubre de 1983 concluye el periodo de registro de Ficorca, mediante el cual 1200 empresas reestructuran deudas con acreedores externos por casi 12 mil millones de dólares a ocho años, con cuatro de gracia.

En abril de 1984 se suscribe un crédito con 500 bancos por 3800 millones de dólares de recursos financieros para satisfacer los requerimientos de divisas de 1984. Las condiciones fueron: un plazo de 10 años, incluyendo cinco años y medio de gracia; costo de $11 / 8 \%$ sobre Prime Rate o 1.5 sobre $L i$ bor; comisiones de $5 / 8$ por una sola vez.

En septiembre de 1984 se concreta la negociación con el Grupo Asesor de Bancos Internacionales para México con objeto de reestructurar 48 mil millones de dólares de deuda con vencimientos entre 1985 y 1990.

Características de la Segunda Renegociación. En el discurso monetarista que impregna las relaciones entre los países y los organismos financieros y la banca mundial, "reestructuración" significa postergación, alargamiento de plazos, mayor endeudamiento y modificaciones del llamado "perfil de deuda"; pero no incluye ningún termino para que finalice la crisis de los países deudores.

No le digo que estoy seguro de conseguir lo que estoy pidiendo [señalaba Miguel de la Madrid]; pero por lo menos quiero avanzar en la negociación y creo que tenemos bases para obtener parte de lo que pedimos. La primera reestructuración fue por los vencimientos de los últimos meses de 1982, de 1983 y 1984, y lo que estoy pretendiendo ahora es lo que los técnicos llaman una renegociación plurianual y eso ya lo han aceptado instituciones financieras internacionales y gobiernos extranjeros [...] México no va a decir, en un acto de machis- 
mo financiero internacional "debo, no niego; pago, no tengo" y, ya pagó la deuda externa. Declarar la guerra económica sería poner en peligro el crédito del país [...] las represalias podrían ser económicas, causar hambre y frenar el desarrollo $[\ldots]$ y de ahí que se renegocie la deuda para buscar la reestructuración de los vencimientos de 1990, para que el nuevo gobierno no entre con las angustias con las que yo me encontré $[\ldots]$ Uno de los problemas más serios que enfrenté cuando tomé posesión del gobierno es que no había divisas en el país, no había dólares y había peligro de que la economía de México sufriera una paralización. Mi objetivo fue lograr la reestructuración parcial de la deuda externa, lo cual se logró con la transformación en créditos de mediano plazo de los vencimientos que se habían dejado de pagar en 1983 y 1984 . No sólo quiero que me den más plazo respecto de lo que debo; sino necesito más dinero... ${ }^{4}$

En la segunda renegociaciónıde la deuda externa mexicana se reestructuraron 48 mil millones de dólanes, que representan el total de los vencimientos de la deuda: externa del sector público con bancos comenciales extranjenos entre 1985 y 1990, de la siguiente manerat ${ }^{45}$

1. 23 mil millones de doblares que hacen el total de los vencimientos de 1982-1984 y que fuenon neestructurados.

2. 20 mil millones de dólares de los vencimientos naturales entre 1985 y 1990 que no habían sido nestructurados; y,

3. 5 mil millones de dólanes de dinena fresco de 1983.

4. El plazo de los 43 mil millones de dalanes compuestos por la deuda ya reestructurada y la no neestructurada, que vencía entre 1985 y. 1990 se transforman en un plazo de 14 años; con un esquema de pagos cnecientes que se inician en 1986 con un monto simbólico de 250 millones de dólanes y aumentan: paulatinamente conforme aumente la capacidad de refinanciamiento del país. El pago más voluminoso durante esta administración es por mil millones de dólares en 1988 y subirá paulatinamente hasta seis mil millones en 1998.

${ }^{44}$ Excélsior: "Desayuno de 20 mujeres y un hombre", 21 de julio de 1984.

${ }^{45}$ Nacional Financiera. "Concluye el proceso de reestructuración de la deuda pública externa", en El Mercado de Valores, año XLV, núm. 36, 9 de septiembre de 1985. p. 1 : 
En el caso de los cinco mil millones de dólares de dinero fresco de 1983, el tratamiento será diferente: en primer lugar, se preparan mil millones de dólares en 1984 y los cuatro mil millones de dólares restantes, que constituyen la deuda más cara del sector público, se pagarán a 10 años de plazo con cinco de gracia.

5. Costos: de los 43 mil millones de dólares se logró eliminar el Prime Rate. Las tasas aplicadas serán la tasa Libor y para sustituir el Prime Rate se usará la tasa de Certificados de Depósito, que es básicamente idéntica y a veces ligeramente inferior a la Libor. El diferencial será $7 / 8 \%$ durante los primeros dos años, $11 / 4 \%$ por los últimos siete años. El promedio ponderado es de $1.11 \%$, ligeramente inferior a $11 / 8$.

Los cinco mil millones de dólares de dinero fresco de 1983, con diferenciales de $21 / 4 \%$ sobre Libor y $21 / 8 \%$ sobre Prime Rate se transforman a $11 / 2 \%$ sobre Libor y a $11 / 8 \%$ sobre Prime Rate. Por este concepto el ahorro será cercano a $40 \mathrm{mi}-$ llones de dólares anuales. No se pagará comisión de reestructuración; las nuevas tasas entran en vigor para todo el paquete el 1 de enero de 1985.

En resumen, por concepto de intereses al exterior, el sector público mexicano ahorrará un promedio de alrededor de 350 millones de dólares por año durante la vida de la reestructuración. Los ahorros de 1985 y 1986 ascienden a casi 500 millones de dólares y descienden paulatinamente conforme aumenta el diferencial hacia los últimos años.

6. Cambio a monedas distintas del dólar. Ante la incertidumbre de tener que fondear dólares por un plazo tan largo, México y los bancos no estadounidenses acordaron que estos últimos pueden cambiar una parte de los saldos en dólares a sus monedas domésticas.

La estructura anterior permite disminuir el riesgo cambiario que representan dichas monedas a lo largo del tiempo, ante la posibilidad de una devaluación futura del dólar. Por otro lado, dichas monedas operan con tasas más bajas que las del dólar, lo que permite compensar su revaluación y, en 
el corto plazo, atenuar el peso del servicio de la deuda por concepto de intereses.

De esta manera quedó resuelto "momentáneamente" el problema de la deuda externa de México durante ese año. Dado que dicha renegociación se hizo bajo el supuesto de que México seguiría consolidando su recuperación y tuviera un periodo de crecimiento sostenido. Los vencimientos entre 1985 y el año 2000 incluyeron las necesidades de financiamiento de dichos vencimientos; así, los requerimientos de dinero fresco hasta 1990 fueron calculados para que se refinanciara a través del mercado, en el supuesto de que México siguiera consolidando su recuperación entre un periodo de crecimiento sostenido. ${ }^{46}$

En relación a la deuda externa, Miguel de la Madrid es claro en varios aspectos: México ha alcanzado tal grado de integración de su economía con Estados Unidos, que no soportaría una "guerra económica" motivada en una moratoria unilateral; México, a través de esta administración, ha aceptado la "renegociación plurianual". México considera legítima su deuda externa "invertida en petróleo, en electricidad, en petroquímica, en fertilizantes, en presas, en carreteras, en servicios urbanos de agua potable, alcantarillado..." enumeró el Ejecutivo. ${ }^{47}$ Estas premisas impregnan el discurso de su administración, orientada por el axioma del "buen pagador",ya que "el crédito del país forma parte del patrimonio que van formando las generaciones a través del tiempo". Lo que nunca queda claro es por qué las generaciones anteriores se beneficiaron contrayendo deudas que la presente generación tendrá que pagar. ¿No será que, en cambio, las transformaciones en las relaciones al interior del mundo capitalista implican que la economía de México, integrada a la estadounidense, haya cambiado de función pasando de receptora de créditos a exportadora de capitales? Si fuera así,

${ }^{46}$ Gurría Treviño, Angel. "La restructuración de la deuda: El caso de México", en Griffith-Jones, Stephany. "Deuda Externa, Renegociación y Ajuste en la América Latina”. El Trimestre Económico, núm, 61, FCE. México, 1988.

${ }^{47}$ Excélsior. 21 de julio de 1984. 
el país no estaría sufriendo una "crisis" que se supone pasajera. Más bien habría entrado en una nueva etapa de participación en la economía mundial, que supone crecientes restricciones al desarrollo autónomo y a los ingresos de las capas trabajadoras.

Los anteriores conceptos aparecen bastante claros en el discurso presidencial y en las declaraciones de los principales responsables del gabinete. Allí se revela que México ha perdido, en los últimos años, hasta la posibilidad de la autosuficiencia alimentaria:

Los tiempos han cambiado [diría Miguel de la Madrid] ya que no se acostumbra usar la fuerza militar para cobrar deudas; pero en el mundo en que vivimos, la represalia económica puede tener, incluso, un efecto más devastador que una guerra. México necesita importar alimentos, maíz y sorgo, cuando las cosechas han ido mal hemos importado trigo y arroz. Una represalia económica que nos impidiera importar alimentos provocaría hambre en el país ${ }^{48}$

Según la estrategia oficial, México no puede salir avante sin pnofundizar su integración total al modelo económico imperante: Frente a esta nealidad, la administración sexenal ha adoptadb el criterio de la " "nenegociación plurianual" de que hablaiel Presidente. Lo que supone renegociar sucesivamente los crecientes adeudos por lo menos hasta 1990 , afirma De la Madrid, " "...para que el nuevo gobierno no entre con las angustias con las que yo me encontré". ${ }^{49}$ Así, el nuevo gobierno se hallará prisionero de los compromisos establecidos en las "renegociaciones", con la continuidad del mismo ciclo de reendeudamiento a finish. Este discurso es, evidentemente, contradictorio con aquél que se citó al principio de este acápite donde se da por "concluido" el pnoceso de reestructuración. Jesús Silva Herzog, fue todavía más explícito:

el modo correcto de tratar con un deudor en problemas de liquidez es hacer que aumente su capacidad de pago, no que la disminuya.

${ }^{48} \mathrm{Ibid}$.

${ }^{49}$ Ibid. 
Sería irreal el superávit de los deudores para obligarlos a reembolsar una parte sustancial del principal de la deuda. Los países deudores tienen que reajustar sus economías: remover la demanda excesiva y la sobrevaluación de la moneda, cortar subsidios e imponer sacrificios a la capacidad de consumo de la población... ${ }^{50}$

Lo que en idioma común significa comprimir los salarios para obtener las remesas de pagos de los intereses de la infranqueable deuda externa.

"'Sólo en casos excepcionales, como el de México, es previsible que el superávit en comercio exterior sea mayor que los pagos de interés y permitan un incremento significativo de reservas", lo que significa que sólo excepcionalmente es previsible esperar que la erogación por servicios de la deuda pueda ser financiada con base en el mejoramiento de los ingresos provenientes del intercambio internacional. Queda, entonces, un solo camino: las medidas de austeridad. Pero, cuidado:

tales medidas, por sí solas, ciertamente no son suficientes para aumentar, en grado significativo, la capacidad de reembolso. Primero, porque al irse tomando estas medidas, es casi inevitable un vasto desempleo y, por tanto, se vuelve difícil sostenerlas por periodos largos, si no se hace algo más. Segundo, porque el superávit de divisas extranjeras que surge de las medidas correctivas, aunque sea de tamaño considerable en términos corrientes, siempre será pequeño en relación con el necesario desembolso [...] Por tanto, es imperativo el aumento en las exportaciones; remover la sobrevaluación de la tasa de cambio y reducir los costos del trabajo. ${ }^{51}$

Al fin, todo queda claro: los superávit en la balanza para las remesas de pagos, tendrán principalmente como origen la reducción de los costos del trabajo. Objetivo real del llamado "proceso de reestructuración" que, por ello, se complementa con las medidas de política económica que recomienda el FMI.

${ }^{50}$ Euromoney. Declaraciones de Jesús Silva Herzog, octubre de 1985.

51 Ibid. 
Según Silva Herzog, la solución al problema de la deuda en 1983, debía provenir tanto de los países deudores como de los acreedores, y ser producto de cinco medidas:

El incremento del comercio con los países ricos; un tope a las tasas de interés en función de la reestructuración; el fortalecimiento de los sistemas fiscales; el aumento de la eficiencia de las economías nacionales; y el fortalecimiento de la capacidad financiera de las instituciones multilaterales. ${ }^{52}$

Sin embargo, en años posteriores el equipo económico mexicano se vio obligado a ceder en la rigidez de las medidas de corrección y austeridad impuestas al inicio del sexenio. El riesgo de una crisis social, generada al recaer todo el peso de la "reestructuración" en el sector laboral, condujo a una flexibilización de esas medidas y, en consecuencia, a un incremento del superávit en el intercambio.

Francisco Suárez Dávila manifestó que en la reunión de Quito del Grupo de Cartagena (y en carta enviada por un grupo de presidentes latinoamericanos a los jefes de Estado de los principales países industrializados) se había acordado establecer un código de conducta en materia de deuda que sirviera como marco de referencia para apoyar las negociaciones individuales de cada país, en función de sus "circunstancias específicas". Hizo presente que en aquellos documentos se estableció el principio de que

la capacidad de pago y su compatibilidad con el crecimiento económico debería regir todo compromiso sobre deuda externa [y agregó] que el problema no estaba resuelto en tanto persistiera la excesiva carga del servicio de la deuda, las dificultades para aumentar nuestras exportaciones a los países industrializados y el alto costo social y político del ajuste para los países deudores. [Para mayores detalles precisó:] durante la primera mitad de 1985 [...] se comenzó a reducir el ritmo de crecimiento de los países industriales, se recrudeció el proteccionismo, el deterioro del petróleo creó cierto pesimismo con respecto a las perspectivas de México y Venezuela. En varios países latinoa- 
mericanos se registraron problemas adicionales: en nuestro país aparecieron nuevamente algunos desequilibrios financieros y se dificultó el control de la inflación; en Brasil, la muerte de Tancredo Neves coincidió con la no conclusión de un acuerdo con el FMI; en Argentina, el problema económico tropezaba con fuertes dificultades... ${ }^{53}$

Luego de la experiencia propia y ajena, concluía: “Todos estos factores han dado lugar a un cambio de percepción más realista en torno al problema global de la deuda...' Sin duda, una reflexión sobre el alto costo de los planes de austeridad, elemento que había permanecido ausente en el discurso oficial en la renegociación de 1983.

El funcionario, naturalmente, no cuestiona la legitimidad de la deuda ("Ha coadyuvado a la formación de capital y a las altas tasas de crecimiento registradas en México a lo largo de los últimos cuarenta años"), pero define el "problema de la deuda" como resultado de la disminución de la demanda mundial y nacional cuando aumenta la capacidad productiva del país y cuando aumentan los costos del servicio. En seguida trata sobre lo que considera la "naturaleza del problema":

El problema no es de decidir entre "pagar y no pagar". La deuda es, en efecto, "impagable". Ningún país, ni desarrollado ni en vías de desarrollo "paga" la deuda. El sacrificio para nuestro país de "'pagar" la totalidad de la deuda de $95 \mathrm{mil}$, de 50 mil o de 20 mil millones de dólares, sí sería insostenible. Los acreedores tampoco lo esperan"..

Sería pertinente, entonces, preguntar ¿Qué esperan los acreedores? y a renglón seguido se obtiene la respuesta: "A la deuda se le da servicio, se le renueva, se le refinancia". Y agrega Suárez Dávila alterando, inconscientemente, los términos de la cuestión: "Lo importante es que se tenga una deuda frente a la cual existe capacidad de darle servicio".

El criterio pertenece a la lógica de los usureros: lo importante es endeudar al cliente, luego, es cosa de él cómo paga.

${ }^{53}$ Nacional Financiera. El Mercado de Valores, 1985. 
Siguiendo con el razonamiento de los banqueros, explica que los pagos se pueden "demorar", pero de ninguna manera se puede "repudiar la deuda"; porque de otra manera caerían las siete plagas sobre México:

vendría por ejemplo una suspensión indefinida del crédito de proveedores para los importadores; la cancelación del financiamiento para la importación de alimentos. Habría que pagar todo al contado. Habría repercusiones en el mercado petrolero [...] ¿Qué sucedería en la zona fronteriza? ¿Sería atractivo este país para la inversión extranjera o las maquiladoras? ¿Seguirían los financiamientos preferenciales del Banco Mundial o del BID? ${ }^{54}$

Las amenazas culminan con la conclusión de que "vivimos en un mundo interdependiente" en el cual -está implícito- las condiciones no las ponen las naciones sino los usureros internacionales. Así, en todo el sexenio, los representantes de las finanzas nacionales de México, a través de discursos, en reuniones de la banca multilateral y de los acreedores internacionales siguieron la dinámica de que lo peor sería declarar la moratoria y lo mejor continuar con el pago del servicio de la deuda. En el transcurso del sexenio 19821988 y del siguiente gobierno 1988-1994 el proyecto neoliberal en nuestro país se haría más profundo.

El país, al fin, debe satisfacerse con realizar algunos ahorros por concepto de intereses y celebrar que se le siga endeudando, aunque en 1985, se incorporó un nuevo factor: "la búsqueda de nuevas formas que satisfagan equitativa y pragmáticamente los intereses reales de las partes, haciendo ver que para poder pagar, es necesario crecer". ${ }^{55}$ Manifestación que encierra la preocupación oficial por el costo social que lleva implícita la renegociación de la deuda.

54 Ibid.

${ }^{55}$ Posteriormente, el Presidente emitió un mensaje a la nación en febrero de 1986. 


\section{La Tercera Renegociación}

Antecedentes. El 21 de febrero de 1986, ante un recrudecimiento de la crisis provocada por la brusca caída de los precios de los principales productos de exportación mexicanos -especialmente los hidrocarburos-, el Presidente acentuó esta línea de negociación: "los acreedores tendrán que hacer, cuando menos, un esfuerzo equivalente al que ha realizado el país". En ese discurso a la nación, Miguel de la Madrid puntualizó: "no enfrentaré el enorme reto externo que ahora nos amaga por la vía de reducir el nivel de vida de los campesinos o abatir los salarios reales de los trabajadores". En el mensaje de $\mathbf{4 5}$ minutos, plagado de retórica nacionalista, el Ejecutivo reafirmó la voluntad gubernamental de seguir haciendo frente a los pagos; pero ahora "....ajustando el servicio de la deuda a la capacidad real de pago del país". México, achicando las distancias que lo separaban de otros países latinoamericanos que impusieron condiciones a los acreedores, empezaba en 1986 a soslayar la posibilidad de negociar una "moratoria". Sin embargo, ningún cataclismo sacudirá al país. ${ }^{56}$ Simplemente se tratará de la tercera renegociación de una serie que no se agotará allí. Se sucederán otras "reestructuraciones" que harían posible aplazar los pagos del principal y rediseñar un cambiante "perfil de deuda", compatible con la capacidad de soportar la extraordinaria sangría que sufren las clases populares; nuevas postergaciones de pagos que solo difieren en el tiempo la hora de la penuria extrema de nuestra sociedad, sacrificada en el altar de la única "reestructuración" que realmente se está procesando: la del capitalismo internacional. La tercera renegociación de la deuda externa se planteó oficialmente en

${ }^{56} \mathrm{El} 21$ de febrero, en un mensaje al pueblo de México desde Palacio Nacional a través de la radio y la televisión, De la Madrid dijo que en virtud de la pérdida de seis mil millones de dólares por el desplome de los precios de los hidrocarburos, su gobierno iniciaría durante esa semana nuevas negociaciones con los acreedores. Cf. Tiempo. México, 4 de marzo de 1986. 
el PAC de junio de 1986 en el marco del Acuerdo de tipo stand by firmado por nuestro país y el FMI. ${ }^{57}$

Características del Acuerdo de Renegociación. ${ }^{58} \mathrm{El}$ paquete financiero de 60 mil millones de dólares que México suscribió con la banca comercial fue refinanciado en su mayor parte a un plazo de 20 años con siete de gracia. Con ello se mejora el costo de más de 43700 millones de dólares de la deuda pública externa y de 9500 millones de dólares de la deuda privada externa. Además, la bança comercial mundial otorgó nuevos créditos por 7700 millones de dólares como apoyo al programa económico de México. El paquete financiero comprende una segunda reestructuración de adeudos - la primera fue en 1982- cuyos vencimientos estaban previstos para iniciarse en 1987, y se prolongarán a 20 años con siete de gracia y se reducen los spreads (sobretasa que se fija acerca del costo del dinero fondeado) de alrededor de 1.12 a 13/16.

Además, esta reducción se aplica también al dinero "fresco." obtenido por México en 1983 y 1984. Los cinco mil millones y 3800 millones de dólares, respectivamente, que fueron contratados a una tasa promedio de $11 / 4$, con lo que en total se logra un ahorro para el país de 250 millones de dólares al año. Los 7700 millones de la banca comercial son independientes de otros seis mil millones de dólares que otorgarán el FMI, el BM, el BID y gobiernos de otros países, como el caso concreto de Japón, que comprometió mil millones de dólares; 500 millones de dólares para el proyecto petrolero del Pacífico y el resto para la segunda etapa de la Siderúrgica Lázaro Cárdenas-Las Truchas y el programa de fomento de exportaciones no petroleras, cuyos recursos pronto comenzarán a fluir. La reestructuración incluye 1800 millones de dólares con el Club de París. En el acuerdo se indica la siguiente cláusula: México podrá disponer de 1200 millo-

57 Nacional Financiera. "Negociación para restructurar la deuda externa", en El Mercado de Valores, añ̉o XLVI, núm 11, 17 de marzo de 1986.

58 Nacional Financiera. "Acuerdo con la Banca Comercial Internacional", en El Mercado de Valores, año XLVII, núm 13, 30 de marzo de 1987. 
nes si el precio del petróleo se reduce por abajo de los nueve dólares por barril, y de los otros 500 millones si la tasa de crecimiento de nuestra economía es menor al $3 \%$ en el primer trimestre de $1987 . .^{59}$

El tercer acuerdo de renegociación se llevó a cabo con sus acreedores en tres etapas.

La primera se realizó con los organismos financieros internacionales: el FMI, el BM y el BID. La segunda se realizó con instituciones financieras gubernamentales de los países industriales. Se llevaron a cabo negociaciones con el Club de París y negociaciones con el gobierno de Japón y la tercera se efectuó a través de las negociaciones con los bancos privados internacionales.

Los principales objetivos de las negociaciones con los bancos fueron: 1) proteger la economía de los choques externos. 2) Obtener los recursos financieros externos necesarios para cubrir la necesidades de 1987 y 1988. 3) Reducir las transferencias netas de recursos al exterior. 4) Alcanzar una relación más adecuada entre los requerimientos del servicio de la deuda y la capacidad de pago del país, mediante mayores plazos y menores tasas de interés. ${ }^{60}$.

\section{Del plan Baker a los bonos cupón cero}

La antesala del caos financiero, económico, político y social se vislumbró desde mediados de la década de los años ochenta como un problema de seguridad nacional para Estados Unidos. Las posibilidades de una moratoria en cualquier país latinoamericano, pero específicamente en México, Brasil o Argentina han estado presentes en los últimos años. Por lo cual se reconsideraron las posiciones de los acreedores y, muy especialmente, la posición del Departamento de Estado del gobierno de Washington. A raíz de las preocupaciones suscitadas por la descapitalización de los países latinoamerica- 
nos, pero más aún por la preocupación política de los regímenes como México, Brasil y Argentina de formar un Club de Deudores o llegar a un acuerdo de renegociación multilateral o incluso de formar un frente común de deudores, el secretario de Estado presentó ante los organismos oficiales y privados y la comunidad financiera internacional el Plan Baker.

\section{El Plan Baker}

La estrategia del Plan Baker consistió en cambiar el acento del " ajuste recesivo" al "crecimiento" de las economías deudoras pero presionando sobre las naciones deudoras a que se adoptaran cambios de política que facilitaran la recuperación del crecimiento a mediano plazo; atraer más inversión directa extranjera; transformar en empresas privadas las industrias estatales ineficientes; eliminar las regulaciones de sus mercados financieros; procurar mayores exportaciones y reducir el gasto gubernamental y abatir las barreras a la importación. El plan hizo necesario restaurar las corrientes de financiamiento destinadas a los países deudores. ${ }^{61}$

El Plan Baker fue anunciado oficialmente en las asambleas anuales del FMI y el BM en Seúl, Corea. Fue una expresión de la "voluntad" estadounidense "para efectuar nuevas y considerables concesiones en los términos de pago de la deuda de los países del Tercer Mundo". Dicho plan se presentó como una estrategia novedosa para reactivar las economías de los países en desarrollo que enfrentan problemas severos de endeudamiento, a través de la reanudación de las corrientes de financiamiento externo provenientes de los bancos y para responder, de este modo, al propio problema de la deuda ${ }^{62}$ El "plan de ayuda" similar al de la posguerra (así se decía) usado para los países europeos (Plan Marshall) abarcaría 20 mil millones de dólares para el financiamiento de la región.

${ }^{61}$ Véase el apartado Caracteristicas de los Acuerdos del FMI, p. 149

${ }^{62}$ Navarrete, Jorge Eduardo, "La Deuda Externa y el Plan Baker", en Investigación Económica, núm. 175, enero-marzo de 1986, pp. 11-33. 
El lema principal de éste fue crecer para pagar. Por ello el Plan Baker fue severamente criticado en los países deudores, por la mínima disponibilidad de financiar mayores créditos y sí exigir el pago de la deuda. Dichos objetivos manifestaron su presencia en la orientación hacia la economía mexicana en 1986 al firmar un nuevo acuerdo con el FMI de tipo stand by, cuyo argumento señalaba el crecimiento de junio de 1986.

A pesar de los buenos deseos del Plan Baker no logró que los países mejoraran sus condiciones. Fue un éxito porque los países siguieron pagando el servicio de su deuda puntualmente, como el caso de México. A tres años de distancia los efectos del Plan Baker en México fracasaron pues el decremento pronunciado de los precios del petróleo y la variable del pago del servicio de la deuda externa, provocaron el fenómeno hiperinflacionario en nuestro país. Ante ello el gobierno propuso un plan recesivo para contener la inflación. ${ }^{63}$

\section{Los swaps}

La capitalización de pasivos es una modalidad nueva en el esquema alternativo para solucionar los problemas de liquidez que han venido enfrentando las empresas tanto del sector público como del sector privado. La capitalización de pasivos por parte de inversionistas extranjeros y nacionales dentro del mecanismo swap ha ayudado a sanear las finanzas de las empresas y orientar dichos recursos a sectores específicos como el automotriz y el turismo $(30$ y $23 \%$, respectivamente). La explicación teórica de los swaps es de primordial importancia en nuestro trabajo al relacionar paralelamente los mecanismos utilizados por la política de Miguel de la Madrid y las alternativas y soluciones novedosas al endeudamiento externo. Esto, sin lugar a dudas, corresponde a la necesidad intrínseca de los acuerdos firmados con el FMI y la lucha por

${ }^{63}$ Excélsior y La Jornada, octubre y noviembre de 1985 . Véase también Contextos, año 3, núm. 64, marzo de 1986 y El Acuerdo firmado de México con el FMI del tipo stand by durante junio de 1986. 
abrir y dar mayores facilidades de los inversionistas extranjeros. La necesidad intrínseca de la reproducción de capital de convertir los pasivos en activos permiten una mayor participación de nuevos agentes en el proceso de la producción, siendo principalmente las empresas trasnacionales las que se han visto beneficiadas por dicho mecanismo, al poder canalizar recursos del exterior a países con grandes perspectivas de desarrollo, dando los cambios estructurales en el marco del ajuste a nivel internacional.

Hasta el primer trimestre de 1987 se habían tramitado compras de deuda por poco más de 1500 millones de dólares. De ellos se llevó a cabo la operación efectiva de $800 \mathrm{mi}$ llones. Por su origen $43 \%$ de las operaciones realizadas para adquirir deuda mexicana fueron efectuadas por inversionistas estadounidenses. El $12.7 \%$ corresponde a los ingleses, $11.9 \%$ a Alemania Occidental, $8.3 \%$ a Japón, $6.5 \%$ a Panamá, 5.9 a capital español y $11.4 \%$ a diversos países. ${ }^{64}$

El esquema de los swaps ha representado un elemento clave en el marco del GATT y de la reconversión productiva, pues se busca que aquellos inversionistas que participan en el mecanismo tengan objetivos bien definidos como la exportación y la modernización. El manual operativo señala al respecto:

el esquema de capitalización de pasivos y la sustitución de deuda pública por inversión debe su origen fundamentalmente a dos necesidades básicas: por una parte, proveer de financiamiento accesible principalmente a través de capital de riesgo, al sector industrial del país, y por otra, en concordancia con la corriente internacional de atracción de flujos de inversión extranjera directa, realizar una promoción selectiva de dicha inversión hacia sectores y productos que contribuirán al cambio estructural del aparato productivo. ${ }^{65}$

${ }^{64}$ Comisión Nacional de Inversiones Extranjeras y Secretaría de Hacienda y Crédito Público. Manual operativo para la capitalización de pasivos y sustitución de deuda publica por inversión.

65 Ibid. 
El esquema de capitalización de pasivos y sustitución de deuda pública por inversión, entró en operación a partir del segundo semestre de 1986, fundamentándose en la cláusula 5.11 del New Reestructure Agreement. ${ }^{66}$ A pesar de que se instrumentó en esa fecha la inversión extranjera captada a través del esquema durante 1986, representó el $50 \%$ del monto total registrado en ese año, lo cual puso de manifiesto el intento inmediato por parte de los inversionistas extranjeros.

\section{Bonos Cupón Cero}

A partir de la crisis financiera los países prestatarios, sobre todo aquellos considerados de alto riesgo, tuvieron una caída en el precio de la deuda externa. De esta manera, la deuda de naciones como México, Brasil, Argentina, Perú y otros países latinoamericanos se depreciaría en el mercado internacional. Tan es así que los títulos de la deuda externa de México han llegado a valer en el mercado internacional de capitales 52 centavos por dólar de endeudamiento concertado. Dado que el comprar la deuda en dicho mercado traería la disminución nominal de casi la mitad de la deuda externa total, la Secretaría de Hacienda y Crédito Público optó por hacer un llamado a los principales acreedores para buscar una alternativa beneficiosa para ambas partes y capturar deuda a un precio bajo a través del mécanismo de los bonos "cupón cero". Con esta medida el gobierno mexicano mejoraría su perfil de endeudamiento. Esta proposición la encabezó el Banco Morgan Guaranty Trust durante el mes de febrero de 1988. Se sugirió que los bancos participantes, pequeños y medianos, que prestaron a nuestro país a través de sindicaciones en la década de los años setenta y presionados por los grandes bancos y el gobierno norteamericano para continuar en las renegociaciones, serían los participantes mayoritarios de dicha empresa. 
El objetivo principal fue reducir el monto de la deuda externa del sector público mediante la captura del descuento que existe sobre la misma en el mercado internacional. Se reduce el principal, la disminución consecuente del servicio de la deuda por intereses y mejorará aún más el perfil del pago del principal.

Los bonos "cupón cero" del Tesoro son obligaciones del gobierno de Estados Unidos, que al igual que la nueva emisión de bonos mexicanos fueron a un plazo de 20 años, cuyo rendimiento de intereses no se paga anualmente al inversionista en efectivo, sino que se reinvierte automáticamente y se va agregando al principal del bono hasta su vencimiento, capitalizándose a la tasa de interés pactada originalmente el día de la emisión. Esto permite que, por ejemplo, a una tasa de interés de 8.75 anual, con un pago de contado de 1866 millones de dólares hoy se puedan comprar bonos cuyo valor al vencimiento dentro de 20 años sería de alrededor de 10 mil millones de dólares; es decir, un "apalancamiento" de poco más de 5 a 1 . Al término del plazo, el gobierno de Estados Unidos pagaría al gobierno mexicano el valor capitalizado del bono "cupón cero", que sería equivalente al valor total de los bonos emitidos por México. Es decir, el pago del principal de los nuevos bonos. ${ }^{67}$

El monto de la deuda elegible para dicha operación es la vieja deuda reestructurada del sector público por 43 mil millones de dólares y las operaciones de dinero fresco de 1983 y 1984 por nueve mil millones de dólares.

Ante tal planteamiento los resultados no magnificaron la cantidad que se hubiera deseado que se aprovechara con "bonos cupón cero".

Como resultado de la subasta los bonos por deuda, realizada el 26 de febrero pasado y cerrada el 30 de marzo, se recibieron 320 cotizaciones de 139 bancos de 18 países, por un total de 6700 millones de dólares. De dicho monto, México rechazó el $45 \%$ y aceptó solamente

${ }^{67}$ Nacional Financiera. "Emisión de Bonos de Deuda Externa", en El Mercado de Valores, núm. 2, enero 15 de 1988. 
3665 millones de dólares, con un precio promedio de 69.77 centavos por cada dólar de deuda antigua. Para cancelar los 3665 millones de dólares de la deuda bancaria que fueron aceptados, México emitirá próximamente 2557 millones de dólares de nuevos bonos, que entregará a los bancos acreedores participantes en la operación, con lo que resultará una reducción de la deuda mexicana de 1108 millones de dólares por capital que, a su vez, dará lugar a ahorros por concepto de intereses por 1537 millones de dólares en los próximos 20 años. Además, mediante la inversión de solo 492 millones de dólares de reservas internacionales en "bonos cupón cero" del Tesoro norteamericano (cuyos intereses se capitalizan durante 20 años) queda asegurado desde ahora, el pago del principal al vencimiento de la nueva emisión de bonos por 2557 millones de dólares a plazo de 20 años que se utilizaría para documentar la operación. Lo anterior equivale a que, con 492 millones de dólares, se redujo la deuda total en 1600 millones de dólares de hoy. Es decir, como si se hubiera comprado al contado a un precio de entre 35 y 40 centavos por dólar, considerablemente por debajo del precio del mercado secundario de 50 centavos por dólar. ${ }^{68}$

\section{Balance de propuestas (convencionales) para resolver el endeudamiento}

La estrategia desarrollada por la comunidad financiera internacional y los países deudores puede ser sintetizada en los siguientes puntos: a) llevar a cabo políticas de ajuste estructural concertadas con el FMI, b) una mayor ingerencia del FMI en el otorgamiento de "créditos frescos" a los países con problemas de liquidez, c) una participación de la banca acreedora o banca trasnacional en íntima relación con el Departamento del Tesoro de Estados Unidos, d) los "créditos puente" para evitar posibles "moratorias" particulares o en conjunto por un posible "Club de deudores" y e) la continua sucesión de renegociaciones para alargar el pago de los intereses de la deuda externa.

${ }^{68}$ Nacional Financiera. "Notas sobre la deuda externa y la reciente operación de intercambio de bonos por deuda bancaria", en El Mercado de Valores, año XLVIII, núm. 9, 1 de mayo de 1988. 
Por otra parte, es pertinente mencionar que dichas propuestas se encuentran en el marco de los tipos de interés internacional y de la política monetaria de Estados Unidos. Ante tal situación la administración de la deuda externa abordada por prestamistas y prestatarios no tuvo el éxito deseado pues no se deslindó de los mecanismos que imperan en el ambiente mundial. La baja de los precios de las materias primas entre las que se incluye el petróleo cuyo efecto alterará directamente el pago del servicio de la deuda externa de México. Ahora, las exportaciones de los países latinoamericanos hacia Estados Unidos si bien han sido notables y las importaciones de la región han tendido a disminuir, es mucho más importante el efecto de la reducción de $1 \%$ de las tasas de interés (Libor), que gravan la deuda latinoamericana, produciría un efecto positivo sobre los pagos externos de América Latina, dos veces superior al efecto creador de comercio generado por $1 \%$ de crecimiento de los países desarrollados ${ }^{69}$

La Declaración y Plan de Acción de Quito aporta precisamente algunos elementos al respecto, en el sentido de que la búsqueda de una solución global y de más largo plazo de la deuda es un asunto prioritario que ciertamente está vinculado con los asuntos comerciales pero que debe abordarse por sí mismo, sin subordinarlo o sustituirlo por el problema complementario de un acceso más amplio y estable de nuestras exportaciones a los mercados sobreprotegidos de los países del norte ${ }^{70}$ Relacionar el servicio de la deuda externa al incremento del comercio de los países latinoamericanos con los países subdesarrollados, ha sido una propuesta de avanzada que más tarde Perú trataría de llevar a cabo. Sin embargo, Argentina, Brasil, Colombia y México participarían en esta

${ }^{59}$ Rodríguez Mendoza, Miguel. “América Latina y la Política Comercial de Estados Unidos', en Cuadernos Semestrales Estados Unidos: perspectiva latinoamericana, Instituto de Estudios de Estados Unidos, CIDE. México, segundo semestre de 1984 .

70 Godínez, Víctor Manuel. "Comentarios en favor de un nuevo tratamicnto del problema de la deuda en América Latina", en La Deuda externa en Centroamérica. Centro de Estudios Monetarios Latinoamericanos, México, 1987. 
reunión como iniciadores de un movimiento que posteriormente coadyuvó a formar el Grupo de los Ocho. ${ }^{71}$

Cabe mencionar que los países del Consenso de Cartagena definieron una plataforma básica para tratar el asunto de la deuda, así como los temas afines relativos al comercio y a las finanzas. Para tratar el tema de la deuda, esta plataforma cubre tres áreas fundamentales: el planteamiento político básico, las propuestas concretas de medidas específicas de política y las consideraciones institucionales. ${ }^{72}$ Entre las propuestas de política básica se encuentran: a) reducción de tasas de interés, b) la introducción de nuevas características en las operaciones de reprogramación y c) la modificación de regulaciones bancarias en países acreedores. ${ }^{73}$

Tales manifestaciones para solucionar el pago del servicio de la deuda externa están, de alguna manera, reflejadas en la última renegociación concluida por México en 1987 y el Acuerdo de tipo stand by firmado por nuestro país a mediados de 1986. Incluso el lenguaje del Ejecutivo ("para pagar debemos crecer',) caracterizaría el lema empleado posteriormente en el Plan Baker. La necesidad de un mayor financiamiento y la otorgación de "créditos puente" para solucionar problemas de liquidez se traslucen en la disposición que ha tenido la comunidad financiera internacional con México. Sin embargo, dichas alternativas hasta el momento no han sido suficientes.

La necesidad de separar la vieja deuda de la nueva deuda y la necesaria fijación de topes a la tendencia ascendente de las

${ }^{71}$ Comercio Exterior. "Declaración de Quito y Plan de Acción de la Conferencia Económica Latinoamericana"'. Documento aprobado por la Conferencia Económica Latinoamericana, celebrada en Quito del 9 al 13 de enero de 1984, vol. 34, núm. 2, febrero de 1984.

${ }^{72}$ Navarrete, Jorge Eduardo. "Manejo de la deuda de América Latina: planteamiento y políticas", en Investigación Económica, UNAM, núm. 184, abril-junio de 1988.

${ }^{73}$ Nacional Financiera. "Consenso de Cartagena", en El Mercado de Valores, año XLIV, núm. 27, 2 de julio de 1984 y Aschentrupp Toledo, Herman. "Deuda y diplomacia financiera en la estrategia de negociación de México para 1986", en Carta de Política Exterior Mexicana, CIDE, México, año VI, núm. 1, enero-marzo de 1986. 
tasas de interés internacional, no se ha llevado a cabo hasta el momento. Estos dos puntos son de vital importancia para la solución de la deuda externa bajo el principio de corresponsabilidad entre deudores y acreedores. Donde la condicionalidad de los préstamos otorgados por el FMI y el BM sorı paralelos. En el marco de la condicionalidad del Fondo, al proporcionar respaldo financiero a los países miembros, el Fondo debe tener la certeza de que la política económica del país que recibe el respaldo es compatible con las disposiciones del Convenio Constitutivo de la institución. Este requisito se conoce como condicionalidad, y uno de sus principios básicos es que, al resolver un problema de balanza de pagos, el financiamiento y el ajuste deben ser procesos paralelos. ${ }^{74}$

Ante tales planteamientos es importante mencionar la solución presentada por Cuba a lo largo de 1985 y en los años subsiguientes. Fidel Castro ha dicho que la deuda externa es impagable y por lo tanto debe ser anulada. Existen razones políticas, morales, jurídicas y matemáticas que deben ser consideradas para no pagar. El problema de la deuda externa es un problema político que empieza a ser un problema revolucionario. ${ }^{75}$

Otra propuesta fue la realizada por Perú cuando su presidente, el señor Alan García, declaró que su país no pagaría más del $10 \%$ del importe de sus exportaciones por concepto del servicio de la deuda externa. Perú forma parte del Consenso de Cartagena y actualmente del Grupo de los Ocho. ${ }^{76}$

En la última reunión de dicho grupo, México convocó a crear una comunidad de naciones latinoamericanas,

con capacidad política de gestión y decisión que enfrente el fenómeno perverso de la deuda externa, porque no debemos arrastrar y condenar

${ }^{74}$ FMI. Boletín (Suplemento dedicado al funcionamiento del Fondo), septiembre de 1988.

${ }^{75}$ Castro, Fidel. A Divida Externa. Selección temática de febrero a septiembre de 1985 desarrollada por Marta Harnecker. Editores Ltda. Porto Alegre, Brasil, 1986. Título original: La Deuda Externa, publicada por la oficina del Consejo de Estado. 1985.

${ }^{76}$ García, Alan. El Futuro Diferente. Editorial Grijalbo. México 1988. 
a nuestros pueblos a una cadena perpetua de ajustes unilaterales que frustran sus demandas legítimas de desarrollo y bienestar social. La fuga financiera por el pago de la deuda externa agudiza el deterioro de las condiciones de vida de nuestras sociedades, impide el retorno a la senda del desarrollo y obstaculiza la viabilidad de estructuras democráticas en la región. ${ }^{77}$

Una de las conclusiones a las que llegó el Grupo de los Ocho fue la inmediata entrevista con el nuevo presidente de Estados Unidos para llegar a un acuerdo que formule soluciones reales al servicio de la deuda externa.

Las propuestas van y vienen, sólo en el curso de la coyuntura en el marco de la historia reciente presentarán soluciones viables para el bienestar de la sociedad.

77 “'Segunda Reunión de presidentes del mecanismo de consulta y concertación política”, en Comercio Exterior, vol. 38, núm. 10, México, octubre de 1988. 


\section{EL PLAN BRADY EN MÉXICO}

México inicia la década de los años noventa con una alternativa de solución a su deuda externa -en función de las necesidades del capital financiero trasnacional- bajo la crisis estructural del capitalismo y la internacionalización del capital.

La gigantesca deuda externa mexicana planteada como una solución necesaria para lograr el crecimiento y el bienestar social no alcanzado en la llamada "década perdida", es parte ahora de una "nueva" estrategia donde los interlocutores internacionales como el Fondo Monetario Internacional (FMI), el Banco Mundial (BM), el Club de París y el señor Brady buscan una solución de causalidad a través del locutor intelectual, el gobierno mexicano, por lograr satisfacer las necesidades de la reproducción capitalista a través de un lenguaje " nuevo"' como es la modernidad, la estabilidad, el crecimiento y la innovación. En dicho proceso el agente receptor tendrá un nuevo papel, distinto al llevado a cabo durante los últimos cuarenta años planteando metas políticas y sociales diferentes. ${ }^{1}$

Hoy día, la deuda externa no será sinónimo de crecimiento ni mecanismo estabilizador. Ésta desempeñará un papel determinante en la integración de México con Estados Unidos y Japón. Acompañada de una liberalización financiera y comercial y un proceso privatizador donde el Estado interventor dejará sus empresas paraestatales al libre juego de la

1 Caro García, María Concepción. La Deuda Externa a través del Discurso del Poder en México (1982-1988). Tesis de Posgrado. Maestría en Ciencias de la Comunicación. Facultad de Ciencias Políticas y Sociales. UnaM, México, 1989. 
oferta y la demanda. ${ }^{2}$ La rentabilidad y la modernidad del país buscarán satisfacer las necesidades de la reproducción y la valorización en función del capital trasnacional.

La deuda externa dará paso a un novedoso lenguaje y la solución y disminución de ésta permitirá una mayor competitividad en aras de la modernidad.

En este capítulo, el problema de la deuda externa y el reto que significa su solución en los años noventa, será abordado de la siguiente forma: la participación del FMI, el Plan Brady y la participación de los bancos; por último, la nueva renegociación mexicana de 1990.

\section{La estrategia del plan Brady}

No cab́e duda, los años comprendidos entre 1982-1988 se han caracterizado por la falta de financiamiento a los países de ingreso mediano y aquellos de América Latina cuya deuda externa se caracterizaba por haber sido contratada en su mayor parte con la banca trasnacional.

De un total de 49 mil millones de dólares anuales alcanzado en 1981 y 1982, el volumen neto de préstamos bancarios destinados a los 15 países fuertemente endeudados pasó a ser negativo durante 1983-1988, por un total de unos cinco mil millones de dólares. En este último periodo, los pagos efectuados por dichos países a los bancos comerciales por concepto de intereses representaron más de 160 mil millones. Durante el mismo periodo, en cambio, los préstamos oficiales a largo plazo concedidos a dichos países ascendieron a unos 70 mil millones de dólares. ${ }^{3}$

Los bancos trasnacionales se limitaron a suspender los préstamos y así elevar su coeficiente capital/activo para tener la capacidad de hacer frente a las pérdidas sin necesidad de quebrar. ${ }^{4}$

2 Villarreal, René. Los Mitos de la Empresa Pública. Editorial Diana, México, 1988.

${ }^{3}$ Camdessus, Michel. "Fortalecimiento de la estrategia frente a la deuda: La función del FMI y los bancos". Boletín del FMI, 19 de junio de 1989.

${ }^{4}$ Se entiende por coeficiente capital/activo la reserva para pérdidas por concepto de préstamos concedidos. Cuando un determinado activo se considera inco- 
Sin lugar a dudas la renuencia de los bancos a prestar, según el director gerente del FMI es, en primer lugar, "la pronunciada caída del valor de sus títulos de deuda en el mercado secundario" y, en segundo lugar,

vemos el fomento de la tendencia a financiar los déficit de balanza de pagos mediante la acumulación de atrasos, lo cual representa una práctica totalmente inaceptable [...] la acumulación de atrasos de todos los países que han tropezado con dificultades para el servicio de la deuda, tanto los países de bajos ingresos como los de ingresos medianos, ha representado en los últimos tres años alrededor de $11 \mathrm{mil}$ millones de dólares. Cuatro mil millones y 11 mil millones, respectivamente $[\ldots]$ persiste el riesgo de que dichos montos sean aún más elevados en los próximos años. ${ }^{5}$

En tercer lugar, soportar la transferencia neta de recursos del pago de intereses calculados sobre el valor nominal de la deuda cuando ésta ha sufrido una reducción severa de su valor real en el mercado secundario impiden un crecimiento real de las economías que realizan un severo ajuste para darle servicio a sus deudas. "En el caso de los 15 países fuertemente endeudados, esta transferencia ha ascendido a un promedio de unos 25 mil millones anuales en los últimos cuatro años." 6

El entorno propicio para que el servicio de la deuda externa se vuelva de suma gravedad, son las fluctuaciones de los precios mundiales de las materias primas, las tasas de interés internacionales y la fluctuación en los tipos de cambio de la mayoría de los países subdesarrollados. ${ }^{7}$ Los créditos contratados con la banca trasnacional, sujetos a la tasa interbancaria de Londres (Libor) durante la década de los setenta y

brable el monto de la pérdida se deduce de esa reserva y, en consecuencia, no afecta a los ingresos corrientes. Boletín del FMI, 5 de junio de 1989, p. 164; véase Guttentag y Herring. Accounting for Losses on Sovereign Debt: Implications for New Lending. Essays in International Finance, núm. 172.

${ }^{5}$ Boletín del FMI, 19 de junio de 1989.

${ }^{6}$ Ibid.

${ }^{7}$ Mathieson, Donald J. et al. Managing Financial Risks in Indebted Developing Countries. Occasional Paper, núm. 65, FMI, Washington, D. C., junio de 1989. 
los primeros años de los ochenta, han hecho que dependan de una variabilidad muchas veces en extremo encarecedora del servicio de la deuda. Si a ello agregamos que los precios de las materias primas han tendido a la baja y el peso de continuas devaluaciones han provocado procesos inflacionarios e hiperinflacionarios, la situación económica y política de los países más endeudados ha tenido que sufrir cambios estructurales profundos.

Por ello, la estrategia del FMI se centra en la implementación de políticas de ajuste con la participación de los préstamos del BM y del BID en una nueva modalidad llamada de condicionalidad cruzada. ${ }^{8}$ El FMI ha creado el servicio de financiamiento compensatorio y de contingencias ${ }^{9}$ para países con problemas de deuda externa. Y ha insistido en seguir prestando a dichos países a fin de que no se interrumpa el pago del servicio de la deuda externa. Sin embargo los bancos trasnacionales, en la medida en que han visto que sus préstamos corren el riesgo de disminuir e incluso de declararse impagables, han orientado su cartera a los países industriales y se han dedicado ha incrementar sus reservas para enfrentar el no pago de los créditos otorgados a dichos países.

Es necesario sintetizar los pasos de dicha estrategia para ver la causalidad de la política económica implementada a nivel internacional por los consorcios financieros internacionales y los organismos financieros oficiales.

1. Con base en el Plan Baker se presentó la instancia del Plan Brady con el objeto de desplegar mayores opciones para reducir la deuda y el servicio de la deuda llamándola una estrategia reforzada. El Plan Baker estuvo constituido por tres elementos: la adopción de políticas macroeconómicas y es-

${ }^{8}$ Se entiende por condicionalidad cruzada que los préstamos otorgados por el FMl, el BM, el BID, el Club de París y otros acreedores tengan la certeza de encaminarse hacia el objetivo de reducir los desequilibrios de balanza de pagos compatibles con el Convenio Constitutivo y las normas del Fondo donde financiamiento y ajuste sean compatibles.

${ }^{9}$ El servicio de financiamiento compensatorio y para contingencias (SFCC), entró en vigor en agosto de 1988; remplazó al servicio de financiamiento compensatorio (SFC). Véase: Boletín del FMI, (suplemento), agosto de 1989. 
tructurales apropiadas por parte de los países deudores; el respaldo financiero continuo del Fondo y los bancos multilaterales de desarrollo para introducir reformas de política económica y un mayor volumen de crédito de los bancos privados a los países deudores. ${ }^{10} \mathrm{El}$ señor Brady pidió concretamente a los bancos que

supriman las cláusulas contenidas en los actuales acuerdos de préstamos, según los cuales se dispone que los acreedores apliquen un trato uniforme no preferencial a todos sus deudores en las transacciones de negociación de las condiciones de los préstamos; lo mismo se exige de los deudores con respecto a los acreedores. ${ }^{11}$

Los intereses políticos y económicos sobre los países latinoamericanos, han orillado a los bancos acreedores a mejorar su posición frente a los deudores. Profundizar la relación de responsabilidad entre deudores y acreedores fue el objeto de mantener la mutua corresponsabilidad en el papel jugado por ambos sectores a lo largo de la crisis. El fracaso de las políticas de ajuste y la prioridad de dar al servicio de la deuda externa el primer lugar, han ocasionado un profundo deterioro de la democracia poniendo en peligro la estabilidad política de los países deudores.

2. La estrategia del FMI fue señalada a través de varias intervenciones de su director general en diferentes reuniones. En ellas se ha manifestado la necesidad de la reducción de las deudas externas pero con la aplicación de programas de ajuste que impidan poner en duda la estabilidad financiera del sistema internacional. Días después del anuncio del Plan Brady, el señor Camdessus dijo:

No tanto renovar nuestros fines sino renovar los medios $[\ldots]$ ¿Cómo reanudar un crecimiento duradero en los países deudores? ¿Cómo reforzar su capacidad de servir la deuda? ¿Cómo ayudarles a recuperar

${ }^{10}$ Brady, Nicholas F. "EE.UU. propone ampliar la gama de opciones de financiamiento de la deuda de los países en desarrollo" Boletín del FMI, 27 de marzo de 1989 , p. 81.

${ }^{11}$ Ibid., pp. 81 y 90. 
el acceso espontáneo a los mercados internacionales de capital? Para satisfacer estas condiciones, ¿qué es lo que básicamente necesitamos?

Básicamente deben cumplirse cuatro condiciones: 1. Adicionalidad en el financiamiento. 2. Calidad en los programas de reforma económica. 3. Disposición real voluntaria de todas las partes a explorar a fondo las posibilidades ofrecidas por los planes de reducción de deuda. 4. Solidaridad en el manejo de los problemas mundiales. ${ }^{12}$

Pareciera ser que el mundo capitalista enfrenta un serio peligro ante el estancamiento de varias economías de los países subdesarrollados. El cómo lograr el crecimiento es preocupación de Estados Unidos y del FMI. Sin embargo, el crecimiento deseado no es ni responde a los objetivos de una nación con carácter popular. Estos son los deseos del capital financiero trasnacional donde la condicionalidad de los préstamos está encaminada a una integración más profunda de las economías subdesarrolladas con los países desarrollados en el marco de un proceso de acumulación interdependiente. El cuidado en el otorgamiento de los préstamos por parte de los acreedores y deudores que cumplan las reformas económicas estructurales es sinónimo de una mayor precaución en la canalización de los fondos.

3. El Club de París ha desempeñado un destacado papel a partir de la crisis financiera de agosto de 1982 . Por sus manos han pasado infinidad de renegociaciones entre la banca privada trasnacional y los deudores. A partir de los últimos años ha dado otro giro en las renegociaciones diferentes a las del periodo 1982-1988. El Club de París tiene el siguiente sistema de tres opciones de reprogramación. Éste permite adaptarse a las diversas restricciones institucionales, jurídicas y financieras de los acreedores del Club de París. Las tres opciones son:

Cancelación parcial. Se cancela la tercera parte de las obligaciones de servicio de la deuda consolidada y los dos tercios restantes se reprograman al tipo de interés de mercado y a

${ }^{12}$ Camdessus, Michel. "Plan Brady para la deuda y cómo puede ayudar el Fondo"'. Boletín del FMI, 10 de abril de 1989, pp.98 y 99. 
un vencimiento a 14 años, incluido un periodo de gracia de ocho años.

Prórroga de los vencimientos. Se reprograman las obligaciones de servicio de la deuda consolidada al tipo de interés de mercado y a un vencimiento a 25 años, incluido un periodo de gracia de 14 años.

Tipos de interés concesionarios. Se reprograman las obligaciones de servicio de la deuda consolidada a un tipo de interés concesionario y a un vencimiento a 14 años, incluido un periodo de gracia de ocho años; el tipo de interés de mercado se reduce en 3.5 puntos porcentuales o el $50 \%$ si ésta es menor. ${ }^{13}$

El proceso de endurecimiento se ha hecho más flexible, a tal grado que el Club de París ha ido permeando sus objetivos con mayor suavidad hacia los deudores. Incluso en ciertas situaciones ha hecho cancelaciones totales de pagos como el caso de la deuda africana con Francia o el abaratamiento de la deuda vieja de Bolivia y Chile.

Las tres opciones anteriores conforman una estrategia para lograr el crecimiento con cierta especificidad de carácter político y económico. Tal es el involucramiento que llevan a cabo dichas medidas en el caso de México.

\section{La nueva estrategia mexicana}

Debemos manifestar que las características de las renegociaciones llevadas a cabo durante el sexenio del presidente Miguel de la Madrid tuvieron como objetivo primordial posponer el pago del principal y de los intereses a años posteriores. Estas renegociaciones se llevaron en el marco de una estrategia de ajuste implementada con el FMI. A cada renegociación correspondieron una política de ajuste más profundo por las características de las Cartas de Intención firmadas en su momento con el FMI y la recompensa de nuevos créditos. Se usa-

13 “"El Club de París adopta un sistema de opciones para los países de bajo ingresơ". Boletín del FMI, 10 de abril de 1989. 
ron formas de cambio de pasivos por activos (swaps) y los llamados bonos "cupón cero" que lograron una disminución de una deuda de 104 mil millones de dólares a cerca de 101 mil millones de dólares al final del sexenio.

Las características de la actual renegociación son posponer y reducir el pago del principal y de los intereses para reducir la transferencia de recursos por concepto del servicio de la deuda. La renegociación será por un plazo mayor a las anteriores: nueve años de gracia y un plazo de 30 años para pagar. Así como el financiamiento de 7 mil millones de dólares de recursos frescos anuales. Esto permitirá un financiamiento de nueva deuda por más de 40 mil millones de dólares durante el actual sexenio. Es decir, cerca de 90 mil millones de dólares de aquí al inicio del siglo XXI. La necesidad del financiamiento para lograr el crecimiento es el objetivo prioritario de la integración de México con Estados Unidos y otros países. Por ello, el Presidente en el discurso de toma de posesión señalaba:

No volveremos a crecer de manera duradera si seguimos como hasta ahora transfiriendo al exterior, cada año, $50 \%$ del producto nacional. Esta situación es inaceptable y es insostenible. La prioridad ya no será pagar sino volver a crecer. ${ }^{14}$

A partir de dicho momento los frecuentes viajes del secretario de Hacienda a Estados Unidos, Japón y Europa señalaban los lineamientos de una nueva estrategia con el consenso internacional de los acreedores de México. Estrategia cuya causalidad entre el acreedor hegemónico, Estados Unidos, y el deudor modelo, México, llevarían una alternativa diferente con respecto a la deuda.

Todos los actores veían con agrado la disminución de la deuda y las condiciones ofrecidas por el país pero sería únicamente la firma del Convenio de México con el FMI el pri-

14 “"El licenciado Carlos Salinas de Gortari asume la Presidencia de la República". El Mercado de Valores, año XLVIII, núm 24, 15 de diciembre de 1988. 
mer paso para iniciar las etapas de la renegociación con disminución del principal.

De esta manera, la estrategia del FMI se ve plasmada en el PND 1989-1994 al coincidir directamente con los planteamientos de la Carta de Intención. ${ }^{15}$

Es importante destacar los pasos que se han venido dando para resolver el débito mexicano en el marco de la nueva estrategia planteada por el FMI y el Plan Brady. Debemos enumerarlos para percibir el complejo problema de la nueva renegociación con disminución en el servicio de la deuda.

\section{Convenio de México con el FMI}

La Carta de Intención firmada por Miguel Mancera, director general del Banco de México, y Pedro Aspe, secretario de Hacienda y Crédito Público de México, dirigida a Michel Camdessus señala como meta lograr el crecimiento. Sólo que la meta de crecimiento económico fijada será viable a menos que la transferencia neta de recursos hacia el exterior se mantenga a un nivel anual similar a menos del $2 \%$ del PIB. ${ }^{16}$

En el marco de la estrategia del FMI, las autoridades mexicanas solicitaron una asistencia financiera por valor de 2800 millones de Derechos Especiales de Giro (DEGs) para respaldar el programa de ajuste económico de México 1989-1992. Esto se aprobó en abril de 1989. Posteriormente, el FMI amplió su asistencia financiera a México por valor de 3250.7 millones de DEGs en un plan que comprende un acuerdo trienal establecido en el marco del servicio ampliado y un giro en el marco del Servicio Financiero Compensatorio (SFC). Los elementos de reducción de la deuda del acuerdo trienal (DEG 2797.2 millones) incluyen la reserva de un $30 \%$ de

${ }^{15}$ Nacional Financiera. "México Acuerda con el FMI un Programa de Apoyo al Crecimiento Sostenido', en El Mercado de Valores, año XLIX, núm. 8, 15 de abril de 1989; "Plan Nacional de Desarrollo 1989-1994", en La Jornada, 1 de junio de 1989.

${ }^{16}$ Nacional Financiera. Op. cit. 
cada compra para operaciones de reducción de la deuda. Además, el Fondo considerará un incremento del acuerdo establecido en el marco del servicio ampliado de un máximo del $40 \%$ de la cuota de México, que es de 1165.5 millones de DEGs en caso de que se concerten acuerdos financieros con los bancos comerciales acreedores para la reducción del servicio de la deuda.

Destacaremos los puntos más sobresalientes de la Carta de Intención. En el punto 7 inciso c) se menciona que

el programa económico de México se diseñó en el contexto de una reducción significativa de la transferencia de recursos al exterior, de una disminución en la carga del servicio de la deuda, considerando la disponibilidad de recursos externos adicionales en el marco de un horizonte multianual. México intenta concluir acuerdos financieros con los acreedores externos adicionales en el marco de un horizonte multianual. México intenta concluir acuerdos financieros con los acreedores externos conducentes a una reducción inmediata y sustancial de la deuda externa. Esto es sentar las bases para una solución definitiva al problema de la deuda externa del país, a la vez que propiciará durante los próximos años flujos financieros congruentes con las metas de crecimiento económico de México. ${ }^{17}$

En el punto 16 la Carta señala la necesidad de un financiamiento de siete mil millones de dólares o más por año, pero en el marco de una reducción significativa de la deuda externa que no limite el crecimiento del país para finales de la década del noventa.

Deseo de la política económica del presidente Salinas de Gortari, expresado en el discurso de toma de posesión y en repetidos mensajes a la nación, señalado en el punto 27 de la Carta dice así: "las autoridades mexicanas consideran que un financiamiento externo adecuado y oportuno es indispensable para el éxito del programa" ${ }^{18}$ Por lo tanto, son los acreedores los que determinarán nuestro destino y no el for-

17 FMI. "El Fondo aprueba un acuerdo por valor de DEGs 3200 millones a favor de México". Boletín del FMI, 17 de junio de 1989, p. 210.

${ }^{18}$ Véase: La Cara de Intención, op. cit. 
talecimiento de nuestro país como un deudor con un poder de negociación oculto que los mexicanos no hemos sabido desentrañar. En este punto se señala quiénes serán los actores de la renegociación y de dicho financiamiento.

En el momento de la firma del Convenio de México con el FMI se llevaba a cabo el proceso de negociación con el BM para obtener un crédito en apoyo del ajuste estructural por un monto de 1500 millones de dólares, además de los préstamos para proyectos específicos vigentes. México solicitaría posteriormente recursos del BM para apoyar las operaciones de reducción de deuda. El apoyo del FMI, a través del Servicio de Financiamiento Amplio, proporcionó el marco para la consolidación del crecimiento económico.

Se buscaba simultáneamente un acuerdo de reestructuración de deuda con los acreedores del Club de París, reservando una cobertura completa de las exportaciones. Con respecto a los bancos comerciales sería necesario tomar varias decisiones en el muy corto plazo. Soluciones necesarias para legitimar el régimen político del gobierno que permitieran un retorno paulatino de los capitales fugados en años anteriores. Por ello en el punto 27 de la Carta se hacía hincapié en la obtención de un financiamiento satisfactorio de la balanza de pagos mientras se alcanza una solución de largo plazo.

\section{El plan nacional de desarrollo 1989-1994}

La causalidad entre el Convenio firmado por México y el FMI y el PND destaca el lenguaje de cuatro palabras clave en el discurso tanto del Ejecutivo en su presentación como en el contenido del mismo plan. Estas palabras son modernidad, cambio, estabilidad y crecimiento. El reto que plantea el PND 1989-1994 es principalmente el de retomar el crecimiento del país olvidado en el último sexenio a través de una estabilidad de precios y buscando siempre una política de mayor rentabilidad y productividad, por lo cual éste sugiere que el camir.o del cambio estructural ejercido desde 1982 será la línea 
continua para el presente sexenio y se profundiza la búsqueda de un Estado moderno en pos de los cambios necesarios para alcanzar dicho objetivo.

Llama la atención en el punto V del PND mencionado como el Acuerdo Nacional para la Recuperación Económica con Estabilidad de Precios, donde en el segundo inciso de dicho punto menciona la necesidad de la ampliación de la disponibilidad de recursos para la inversión productiva. Es aquí, en este inciso, donde el PND hace hincapié en el fortalecimiento del ahorro interno, en el fortalecimiento de los términos de intercambio y en la reducción de la transferencia de recursos.

El PND, al hacer mención a la disminución de la transferencia de recursos, refiere la renegociación de la deuda externa desde que el presidente Salinas de Gortari manifestó en su discurso de toma de posesión: para crecer México dejará de pagar el oneroso servicio de la deuda externa y disminuirlo a no más del $2 \%$ del PIB para de esta manera regresar el bienestar al pueblo de México.

Desde esa fecha se han dado las instrucciones al Secretario de Hacienda para que a través de un "menú de opciones" presentado a la banca acreedora se tome en cuenta el esfuerzo realizado por México de ser un buen pagador y por lo tanto se empiece a disminuir el servicio de la deuda y de antemano se otorguen a este país créditos frescos.

Al mismo tiempo, hay una relación de çausalidad entre los planteamientos presentados por nuestro gobierno y el reciente Plan Brady, presentado por el Secretario del Tesoro, que es el de que los países no pueden seguir ajustándose el cinturón para pagar por los problemas sociales y políticos que esto implicaría a las democracias latinoamericanas, pero en el caso de México este enunciado cobra más fuerza que en Venezuela o en Argentina por ser México la frontera de Estados Unidos y por el efecto automático que ocasionaría una desestabilización política, económica y social al sur de este país, por ello, es importante mencionar que la causalidad entre los planteamientos del señor Brady y del presidente de México 
en el fondo sugieren el crecimiento como un reto. Además del bienestar es de gran importancia la estabilidad.

El PND tiene íntima relación con la Carta de Intención firmada en el mes de abril de 1989 donde en los puntos 16 y 17 se plantea que el crecimiento difícilmente será alcanzado si la transferencia externa neta no disminuye a menos del $2 \%$ del PIB. Además, la necesidad de cubrir una brecha de financiamiento por siete mil millones de dólares por año por lo cual se necesitan los recursos frescos del exterior. De allí que se asegure una disminución de los pagos de amortizaciones para lograr el crecimiento.

Es dentro de este marco de un avance en la renegociación y en el otorgamiento de créditos frescos como en la propuesta de que parte del servicio de la deuda se posponga por determinado tiempo que el PND fue anunciado un mes después de la firma del Convenio. Se habló de una reducción de $35 \%$ del débito pero no hubo un punto de contacto entre acreedores y el deudor mexicano en relación a las quitas de capital.

Un año después el PND cumpliría sus objetivos: "el valor del PIB a precios constantes se incrementó $2.9 \%$ respecto al nivel observado al año anterior". ${ }^{19}$

\section{Soluciones al "sobrendeudamiento"}

Para poder entender el proceso de la renegociación del débito mexicano es importante señalar lo siguiente:

Una vez expuestas las premisas de la necesidad de la reducción del débito por el presidente de la República el 1 de diciembre, se realizaron entrevistas del Secretario de Hacienda mexicano con los principales bancos acreedores que conforman el Grupo de los Siete. Japón accedió a prestar y otros países mostraron disponibilidad para hacerlo siempre y cuando se firmara una Carta de Intención.

${ }^{19}$ Banco de México, Informe Anual 1989. México, marzo de 1990. 
No cabe duda que los disturbios sociales de Venezuela, ocasionados por la formulación de un Plan de Estabilización durante febrero de 1989, apresuraron el Plan Brady pues se hablaba desde principios de 1988 de la necesidad de reducir el principal de los préstamos desde que John Reed había anunciado que los bancos dejarían de prestar para realizar ahorros sustanciales y enfrentar las pérdidas.

El segundo paso fue la Carta de Intención con el componente de la reducción del servicio de la deuda externa y la íntima relación de ésta con el PND 1989-1994 donde especificaban conjuntamente la necesidad de la reducción para lograr la estabilidad, el crecimiento y la modernidad del país.

Los préstamos otorgados por el BM y el Club de París fueron etapas prestablecidas ante el acuerdo con la banca comercial.

El Acuerdo con el BM consistió en lo siguiente:

El financiamiento de proyectos de inversión por un monto total de 1960 millones de dólares. Los recursos, integrados por tres préstamos de 500 millones de dólares cada uno y otro préstamo por $460 \mathrm{mi}-$ llones de dólares. Dentro de este paquete los tres préstamos de 500 millones de dólares serán dirigidos a apoyar el cambio estructural en los sectores industrial, paraestatal, financiero y comercial; mientras que el préstamo de 460 millones de dólares será destinado para ampliar la capacidad de generación de energía eléctrica, una porción de esos recursos se utilizará para apoyar los esquemas de reducción de deuda con la banca comercial. ${ }^{20}$

El Acuerdo con el Club de París indicó:

México logró un acuerdo multianual que abarca 2600 millones de dólares, que representan los vencimientos de capital a pagarse del 1 de junio de 1989 hasta el 31 de marzo de 1992 y el $100 \%$ de los intereses a pagarse entre el 1 de junio de 1989 y el 31 de marzo de 1990. Asimismo, incluyen el $90 \%$ de los intereses por vencer entre el 10 de

${ }^{20}$ SHCP. "La Renegociación de la Deuda Externa de México", en El Mercado de Valores, año XLIX, núm. 16, 15 de agosto de 1989. 
abril de 1990 y el 31 de marzo de 1991 , y el $80 \%$ de los intereses por vencer entre el 1 de abril de 1991 y el 25 de mayo de $1992 .{ }^{21}$

La cifra de alivio final que se logró en materia de reducción de transferencias con este acuerdo, es la siguiente: para 1989, 519 millones de dólares; para 1990, 773 millones de dólares. El acuerdo también asegura financiamiento irrestricto para las importaciones que México realice de los países miembros del Club de París, el cual se calcula en un mínimo de dos mil millones de dólares anuales durante los próximos seis años. En el marco de la Asamblea de Gobernadores se especificaron los proyectos de desarrollo hidroeléctrico, de reestructuración industrial y de desarrollo forestal en los estados de Durango y Chihuahua. ${ }^{22}$

El acuerdo con la banca comercial. El acuerdo con el Comité Asesor de la banca comercial fue anunciado por el Presidente como la solución al crecimiento del país. Una vez llevados a cabo todos los pasos requeridos en el marco de la estrategia del FMI y del Plan Brady, enunciados en el inciso anterior y después de varios encuentros de los negociadores mexicanos y los representantes de la banca acreedora, el Presidente informó a los mexicanos el resultado del Acuerdo de Renegociación el 23 de julio de 1989. Dicho acuerdo, cuya modalidad es la reducción del principal o de los intereses, acompañada de crédito fresco, es el primero en su tipo.

Dentro del discurso del poder, el mensaje del Presidente a la nación a través de la televisión y de la prensa procuró terminar con uno de los puntos débiles que marcaban inestabilidad a su PND y a las frecuentes amenazas de caer en el proceso inflacionario y perder lo ganado por el Pacto. Así, el Presidente informó:

21 Véase: "El Club de París adopta un sistema de opciones para los países de bajo ingreso", op. cit. y véase también El Mercado de Valores, año XLIX, núm. 16, 15 de agosto de 1989.

${ }^{22}$ Nacional Financiera. "El BIRF otorga préstamos a México", en El Mercado de Valores, año XLIX, núm. 19, 1 de octubre de 1989. 
el arreglo significa que, sobre la base de 53 mil millones de dólares de deuda externa que el gobierno mexicano tiene con los bancos comerciales del mundo, se logrará una reducción del $35 \%$ del principal, o un abatimiento de alrededor del $40 \%$ de la tasa de interés. ${ }^{23}$

La Hoja de términos. Al tomar en cuenta las tres opciones de reducción del principal e intereses acompañados de "créditos frescos" la Secretaría de Hacienda y Crédito Público haciendo mención al "menú de opciones" formulado por México a los bancos acreedores presentó la "Hoja de términos" donde especificaba lo siguiente:

México aportará siete mil millones de dólares de sus propios recursos y de recursos provenientes del FMI, el BM y del Banco de Importaciones y Exportaciones de Japón para colateralizar la emisión de bonos que reduzcan la deuda.

Recibirá dinero fresco y de reducción del principal de la deuda entre dos mil y tres mil millones de dólares anuales.

El programa incluye el intercambio de deuda por capital (swaps) a mil millones de dólares anuales.

Una vez intercambiada "vieja deuda" por bonos nuevos utilizando el $35 \%$ de descuento, el descuento tendrá una tasa flotante de interés equivalente a $13 / 16$ de un punto porcentual sobre la tasa interbancaria de Londres y los bonos de reducción del principal estarán sujetos a la tasa fija de $6.25 \%$ negociada anteriormente.

Los bancos intercambiarán sus préstamos a mediano y largo plazos por bonos a 30 años emitidos por el gobierno de México hasta en 10 diferentes divisas. El total del principal y parte del pago de intereses estará garantizado por el fondo de siete mil millones de dólares descrito antes. El principal será colateralizado en su totalidad y a su madurez por una emisión de obligaciones del Departamento del Tesoro de Estados Unidos que emitirá los llamados "bonos cero".

${ }^{23}$ Palabras del Presidente en un mensaje a la nación por televisión el domingo 23 de julio de 1989. El discurso fue publicado al día siguiente en los periódicos más importantes del país. Días después el Secretario de Hacienda, señor Pedro Aspe, comparecería ante el Poder Legislativo explicando las etapas de la actual renegociación. 
Los bancos acreedores que prefieran optar por otorgar recursos frescos comprometerán un equivalente a $25 \%$ de la exposición crediticia en México a corto y mediano plazo que no sea intercambiada por bonos de reducción de servicio del principal de la deuda, $40 \%$ de los recursos frescos será puesto a disposición de México en un primer desembolso, el último de los cuales se producirá en 1992. Los nuevos créditos serán pagaderos a 15 años con siete más de gracia, y estarán sujetos a un interés correspondiente de $13 / 16$ puntos porcentuales sobre Libor. ${ }^{24}$

El "crédito puente" por dos mil millones de dólares.

Mientras se llevaban a cabo las pláticas con la banca acreedora, difícil de convencer, la banca internacional y de Estados Unidos optaron por conceder el préstamo puente de dos mil millones de dólares para dar confiabilidad al gobierno ante la nación. ${ }^{25}$

Haber sintetizado las diferentes fases de la renegociación con disminución del principal e intereses acompañada de nuevos créditos permitió dar confiabilidad a un plan de ajuste estructural, cuyo objetivo ha sido desde el inicio de su implementación lograr la integración a Estados Unidos y al mercado internacional, sin contar con el apoyo popular ni con objetivos nacionales.

\section{Acuerdo de Renegociación de febrero de 1990}

En el marco del Plan Brady, con la participación del FMI y la anuencia del comité de acreedores de México así como del Club de París, se llegó a la reducción de la llamada deuda histórica de 48 mil millones de dólares. Es importante destacar que al inicio de las pláticas con la banca comercial, el saldo de la deuda susceptible de negociación (deuda elegible) ascendía a alrededor de 52600 millones de dólares. La reduc-

If E. Excellsion, 14 de septiembre de 1989 y Nacional Financiera. "México en"Uf Excélsion, II de septiembre de
vía a la Banca Comercial la Hoja de términos y condiciones", en El Mercado de
Valores, año XLIX, núm. 19, octubre de 1989 .

${ }^{25}$ Cf. Excélsior, septiembre de 1989. 
Los bancos acreedores que prefieran optar por otorgar recursos frescos comprometerán un equivalente a $25 \%$ de la exposición crediticia en México a corto y mediano plazo que no sea intercambiada por bonos de reducción de servicio del principal de la deuda, $40 \%$ de los recursos frescos será puesto a disposición de México en un primer desembolso, el último de los cuales se producirá en 1992. Los nuevos créditos serán pagaderos a 15 años con siete más de gracia, y estarán sujetos a un interés correspondiente de $13 / 16$ puntos porcentuales sobre Libor. $^{24}$

El "crédito puente" por dos mil millones de dólares.

Mientras se llevaban a cabo las pláticas con la banca acreedora, difícil de convencer, la banca internacional y de Estados Unidos optaron por conceder el préstamo puente de dos mil millones de dólares para dar confiabilidad al gobierno ante la nación. ${ }^{25}$

Haber sintetizado las diferentes fases de la renegociación con disminución del principal e intereses acompañada de nuevos créditos permitió dar confiabilidad a un plan de ajuste estructural, cuyo objetivo ha sido desde el inicio de su implementación lograr la integración a Estados Unidos y al mercado internacional, sin contar con el apoyo popular ni con objetivos nacionales.

\section{Acuerdo de Renegociación de febrero de 1990}

En el marco del Plan Brady, con la participación del FMI y la anuencia del comité de acreedores de México así como del Club de París, se llegó a la reducción de la llamada deuda histórica de 48 mil millones de dólares. Es importante destacar que al inicio de las pláticas con la banca comercial, el saldo de la deuda susceptible de negociación (deuda elegible) ascendía a alrededor de 52600 millones de dólares. La reduc-

${ }^{24}$ Cf. Excélsior, 14 de septiembre de 1989 y Nacional Financiera. "México envía a la Banca Comercial la Hoja de términos y condiciones", en El Mercado de Valores, año XLIX, núm. 19, octubre de 1989.

${ }^{25}$ Cf. Excélsior, septiembre de 1989. 
ción del débito se debió a varias condiciones: a) cancelación de deuda externa del sector público, que algunas instituciones oficiales recibieron como pago por la venta de empresas paraestatales que fueron desincorporadas; b) coinversiones de deuda a capital (swaps) autorizadas antes de noviembre de 1987; y c) variaciones del tipo de cambio del dólar con respecto a otras monedas. Todas estas operaciones contribuyeron a dicha reducción. ${ }^{26}$

En dicha renegociación se aplicaron los enunciados siguientes: 1. Reducción de la deuda histórica. 2. Abatimiento de la transferencia neta de recursos al exterior. 3 . Obtención del financiamiento multianual y 4 . Reducción del saldo de la deuda con respecto al PIB.

Por lo tanto, de un saldo cercano a 48500 millones de dólares el $41 \%$ del total se redujo el principal en un $35 \%$. Este intercambio de deuda por bonos significó una reducción de la deuda por cerca de siete mil millones de dólares. En segundo lugar, el $47 \%$ que representó 22500 millones de dólares tuvo una baja de tasa de interés de $9.81 \%$ a $6.25 \%$. Esto significa una reducción por 7750 millones de pesos. El $12 \%$, otorgará a México 1500 millones de créditos nuevos.

Con este acuerdo se presentan dos efectos positivos para la economía mexicana. El primero relaciona la disminución de la transferencia de capital de un $6 \%$ a un $2 \%$ del PIB. En segundo lugar, la disminución de la deuda externa total en relación al PIB pasa de un $60 \%$ a finales de 1988 a un $57 \%$ en 1990.

Así, la "vieja deuda" disminuye junto con el total de la deuda externa del sector público para dar pie a nuevas formas de financiamiento vía el ahorro interno, el mercado de dinero y el mercado bursátil. La vuelta al financiamiento multilateral y bilateral será la tónica de los nuevos créditos

${ }^{26}$ Aspe, Pedro. "Reanudar el Crecimiento, Imperativo Social”'. Discurso pronunciado en ocasión de la firma del contrato del paquete financiero, Palacio Nacional, 4 de febrero de 1990. Edición de Presidencia de la República, Dirección General de Comunicación Social, México, 1990. 
proporcionados a México. Crecerá la llamada "ingeniería financiera" para la reestructuración de pasivos y el saneamiento de las finanzas corporativas del gobierno federal. Se establece el programa de intercambio de deuda pública externa por capital, con el propósito de estimular la inversión nacional y extranjera. ${ }^{27}$

${ }^{27}$ Nacional Financiera. El Mercado de Valores, núm. 8, 15 de abril de 1990. 


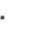




\section{FIN Y PRINCIPIO DE UN NUEVO DESARROLLO}

\section{El equivalente general y el desfinanciamiento del desarrollo}

Durante el transcurso de la investigación y a lo largo del estudio de categorías como el "equivalente general", la concentración y centralización del capital y la ganancia, la participación del capital-dinero en el proceso de internacionalización del capital, nos han llevado a una mejor comprensión del problema. Varios aspectos merecen puntualizarse.

Es importante destacar el dinero y sus leyes como los determinantes del comportamiento del conjunto del sistema. El dinero como forma elaborada de trueque entre agentes económicos, por tanto, el dinero como equivalente general que permite el intercambio entre el trabajo concreto y el dinero. Además, el dinero como capital-dinero participa en la valorización del proceso de acumulación internacional; es decir, la internacionalización del capital, elemento de la reproducción del capital. Y, también, bajo las categorías de concentración y centralización del capital, el endeudamiento externo se vislumbra a los ojos del gran conglomerado trasnacional donde los actores principales son la banca trasnacional y los organismos financieros internacionales.

En el marco del proceso de acumulación internacional el dinero o equivalente general internacional desempeñará un papel primordial en función de la tasa de ganancia y de los diferentes agentes económicos que participan en ella en una disputa diaria por la valorización del capital.

Al estudiar el endeudamiento externo como forma del equivalente general hay un acercamiento al problema en función 
de la interacción de las relaciones de cambio entre acreedores y deudores y la función orgánica que desempeña el equivalente general entre una formación política, económica y social y el conglomerado trasnacional donde los acreedores participan en el proceso de la reproducción del capital junto con los lineamientos ejercidos por la política económica del Estado. Al observar el endeudamiento externo desde dicha concepción como equivalente general que hace posible el intercambio de las mercancías, el proceso de reproducción de capital continúa y se expanden las fronteras para no obstaculizar la valorización del capital. Por ello se desarrolla el proceso de la exportación de capital provocando financiamiento de la pobreza y profundizando la crisis nacional, pues el equivalente general se presenta como una relación social, donde interactúan las relaciones de trabajo a nivel nacional e internacional. Si bien el equivalente general sirve para el intercambio de bienes y servicios en el mercado mundial de productores y deudores, cuando estalla la crisis financiera éste desempeña un papel diferente de forma. Esto es, el equivalente general entra a participar en renegociaciones y a pagar un servicio de una deuda externa, contratada en tiempo pasado pero en dicho momento, difícilmente participan los créditos en el circuito de la producción. El monto cuantitativo que se destina anualmente al pago del servicio de la deuda externa es extraído del pago inadecuado a la fuerza de trabajo y del reajuste y disminución de la participación del Estado en el proceso de acumulación interno.

$\mathrm{Al}$ aclarar que el estudio del equivalente general al que hace referencia Marx, en relación al estudio del dinero como forma de intercambio entre productores y consumidores, es una categoría que representa una moneda de carácter universal mediante la cual se dan los créditos de acreedores a deudores. Dicha categoría internacional, equivalente general, ha pasado por varios cambios de forma y, representa hoy en día un cúmulo de deudas por parte del Tercer Mundo y ha servido para comprar mercancías a los países desarrollados con el objeto de promover su acumulación y expansión -interna- 
cionalización - en periodos de auge económico o para atenuar el efecto de fases recesivas y aun de crisis en dichos países. Entonces, observaremos las categorías de la concentración, centralización y acumulación, génesis del conglomerado trasnacional y del capital financiero internacional.

Tales categorías se manifiestan en el sistema monetario internacional creado durante la segunda mitad del siglo $\mathrm{XX}$ donde los organismos financieros internacionales y los bancos trasnacionales se orientarán a las necesidades del capitalismo. Estos organismos formarán la constelación de poder en cuanto a la disposición, disponibilidad y canalización del financiamiento de la acumulación. De esta manera, el nacimiento del sistema monetario de Bretton Woods y del Fondo Monetario Internacional (FMI), el Banco Mundial (BM) $y$, posteriormente, el Banco Interamericano de Desarrollo (BID), como el fortalecimiento de la gran banca trasnacional, el First National City Bank, el Chase Manhattan Bank, el Mitsui Bank, Mitsubishi Bank, Dresdener Bank, etc., han venido a ser sólo formas de las categorías señaladas arriba. Si bien estas formas de poder nacen bajo el amparo de la hegemonía de Estados Unidos, el desenvolvimiento dependerá de la moneda hegemónica, el dólar, y de la disposición del mismo para el buen funcionamiento de la liquidez internacional. Desde esta óptica el funcionamiento del endeudamiento externo en el sistema capitalista, financiado tanto por organismos internacionales como por bancos privados trasnacionales, dependerá de la adecuación a la tasa de ganancia en el marco de la división internacional del trabajo del sistema capitalista mundial.

En la medida en que el equivalente general internacional relaciona al Estado con el conjunto de las relaciones capitalistas que existen al exterior de su formación económica, política y social, al mismo tiempo se están determinando las formas de la reproducción de capital y la profundización del modo de producción capitalista. Dicho proceso se plasma desde la posguerra, hasta nuestros días, en modalidades que conforman a través del tiempo la política de deuda externa. 
Dicha política, variable dinamizadora del crecimiento económico, tendrá facetas bien definidas que constituirán el lenguaje oficial de la política de endeudamiento externo ligado a la política económica y al discurso ideológico del proyecto del "nacionalismo revolucionario".

Con base en ello, la política de endeudamiento se divide en tres etapas. De los años cuarenta hasta finales de los sesenta. Etapa denominada por nosotros del "despegue económico" al "desarrollo estabilizador". La segunda etapa comprende el resquebrajamiento del sistema monetario internacional y la crisis del sistema capitalista internacional, manifiesta en el aumento de los precios internacionales del petróleo y el fortalecimiento del mercado del eurodólar. La lucha por un modelo trasnacional se basa en la disputa de los grupos sociales vinculados a los intereses más poderosos por tomar el poder y dar pie al tránsito sin violencia social de una mayor integración con el proceso de acumulación internacional. Esta fase la denominamos del "desarrollo compartido" a la "alianza para la producción". La tercera fase de la política de endeudamiento comprende las alternativas y soluciones presentadas a la "crisis de liquidez" y al proceso de "desfinanciamiento". A esta etapa la llamamos de la "crisis de liquidez" al "desfinanciamiento del país".

Desde la perspectiva de un Estado nacionalista hasta un Estado neoliberal, cuyo objetivo prioritario es el desarrollo capitalista, las modalidades enfrentadas por la política de deuda a través de la historia reciente, han conformado las etapas en las que se dividió el objeto de estudio, donde el Estado hizo suyo el "equivalente general"' internacional vía la política de deuda externa para fortalecer su política económica y su relación frente a la sociedad.

Al haber vinculado empíricamente el destino que ha tenido el equivalente general y el financiamiento del gobierno mexicano, en su relación con los intereses de los acreedores en la reproducción de capital a nivel interno, bajo el marco del proceso de acumulación internacional, lleva a concluir lo siguiente: durante los años cuarenta y cincuenta, albora- 
da del crecimiento industrial, los préstamos de origen oficial se canalizaron al financiamiento de la infraestructura y del sector secundario. Quienes participaron respectivamente en dicho proceso fueron el BM y el Eximbank. Los años sesenta caracterizaron el binomio inversión extranjera directa y Estado. En el sector secundario se concentró el financiamiento del BM, Eximbank y el recién creado BID. A partir de 1973, se vislumbra la participación del equivalente general al integrar el proceso agrícola a un proceso interdependiente del exterior, Estados Unidos, dependiente del BM y del BID. Tendencias que no cambian con la crisis del financiamiento durante la década del ochenta, sino que acentúan su participación y su condicionalidad.

De los años cuarenta hasta mediados de los sesenta los organismos financieros cobraron fuerza en el financiamiento del desarrollo perdiendo terreno ante la hegemonía de la banca trasnacional. Sin embargo, no sólo en México sino en América Latina su presencia es notable a partir de 1982, donde el FMI y los organismos oficiales internacionales como el BM y el BID participaran en una condicionalidad cruzada para el otorgamiento de los préstamos a los países subdesarrollados.

La trasnacionalización de la deuda externa es un proceso que se inicia cuando el componente bancario de la deuda externa pública de México toma primacía sobre el componente oficial. Factores externos, como la agresividad bancaria en su oferta de crédito, resultado del creciente mercado del eurodólar y el excedente petrolero dispuesto a ser valorizado. Y factores internos, donde el Estado tenía que cumplir su papel de intermediario benefactor, tanto para el obrero como para el campesino y el sector empresarial, requiere de financiamiento para mantener el proceso de acumulación dentro del discurso del "nacionalismo revolucionario". Estas serían las necesidades que dieron pie al proceso de trasnacionalización abierta en nuestro país durante la década de los setenta y principios de los ochenta. El juego articulado de estos elementos fue la combinación perfecta para convertir a México en principal suministrador de petróleo a Estados 
Unidos en el marco de la estrategia militar del imperialismo estadounidense. El conglomerado trasnacional transformó, vía el equivalente general, el orden estructural de la economía mexicana.

Las alternativas y soluciones para enfrentar el servicio de la deuda externa a raíz de las manifestaciones de la "crisis de liquidez" han venido a presentar la lógica lineal del proceso de reproducción del sistema capitalista. La relación entre los planes de ajuste concertados con el FMI y las renegociaciones plurianuales han extraído más de 60 mil millones de dólares evitando la inversión pública y el gasto público del Estado. La distracción de dichos recursos afectó en gran parte a la población dando inicio a una mayor participación de la sociedad ante los efectos negativos de la crisis. Soluciones como los swaps, los bonos "cupón cero" y la utilización del mercado secundario, no han sido suficientes para bajar el monto de la deuda externa. La condicionalidad por parte de los organismos financieros internacionales y de la banca trasnacional en los créditos forzados y no voluntarios ha impedido un diálogo más fraterno entre acreedores y uno de los más importantes deudores del Tercer Mundo. El periodo llamado de la "crisis de liquidez" al desfinanciamiento del país será el ejercicio del proyecto neoliberal en todo su esplendor. México ha sido digno ejemplo, según la banca acreedora , del comportamiento "responsable" que deben tener los países deudores.

Por ultimo, no podríamos entender, desde teorías económicas diferentes a la economía política, al Plan Brady y a la renegociación de la deuda externa cuyas características sorprenderían en 1982 a cualquier actor del problema del endeudamiento. La necesidad de proseguir con el intercambio de mercancías a través del "equivalente general" y de la valorización del capital en el marco de un proceso de acumulación internacional permitieron a México la solución de su deuda externa. Las quitas al capital y la disminución de los intereses de la "deuda histórica", tienen su significado en el ámbito de la estrategia de México, frente a la integración 
del Mercado Común del Norte y de la globalización de la economía.

\section{Deuda y desarrollo: una propuesta alternativa}

Sería este un trabajo incompleto si culminara con una mera descripción de la estructura de la deuda, del "perfil" que ha adoptado, su bancarización y privatización y la sujeción de las políticas económicas nacionales a los lineamientos de ajuste indicados por los organismos financieros internacionales. Asimismo, sería insuficiente afirmar que la deuda externa de las economías periféricas es el recurso principal que permite canalizar enormes cuotas de plusvalía hacia los centros industrializados y que el endeudamiento externo del Tercer Mundo ha redundado y sigue proporcionando grandes ganancias al sistema financiero internacional, dirigido desde las metrópolis capitalistas, pero arraigado en nuestros países. El todo mencionado constituye actualmente un sistema o conglomerado trasnacional, del mismo modo que la economía interna de los países integrados a ese mercado mundial, está regida por leyes más generales que las que específicamente atañen a cada una de las partes. Abordar un estudio global del sistema en que está inmersa la economía requiere acudir al auxilio de la teoría, intentando romper con las condiciones ideológicas impuestas por las doctrinas dominantes.

Así, el planteamiento del problema de la crisis y deuda externa de México y América Latina debe partir del reconocimiento de la realidad para contribuir a la generación de respuestas más favorables para nuestros países. Por ello es importante el estudio de las características que ha venido adoptando dentro del capitalismo moderno el comportamiento del dinero como equivalente general. La propuesta a presentar, resultado de la investigación, es la siguiente:

A la luz de los acontecimientos desarrollados una vez que se manifiesta la crisis de liquidez y las alternativas y soluciones presentadas por mutuo acuerdo entre acreedores y deudores se percibe que el endeudamiento es parte del proceso 
de internacionalización del capital y parte del financiamiento de la reproducción del proceso de acumulación. Por tanto, la interrupción del financiamiento en el crecimiento y desarrollo de las fuerzas productivas ve imposibilitado, a nivel interno, el proceso de reproducción de capital. A tal grado que el país por la política económica neoliberal es capaz de generar excedente para el pago de la deuda externa, pero no es capaz de generar excedente para el financiamiento del proceso productivo. El pago del servicio de la deuda externa con un costo alto por el incremento real en las tasas de interés y una disminución de los precios de las materias primas, como la baja del precio del petróleo, inciden en una relación desfavorable que se refleja en términos de intercambio continuamente a la baja, lo que origina que la nación deudora sea capaz de pagar la deuda y a la vez seguir financiando el proceso de producción. En el marco de una crisis estructural del capitalismo, el equivalente general es uno de los elementos dinamizadores de un proceso de reproducción interno hondamente interdependiente del exterior. Esto crea condiciones políticas, económicas y sociales que impiden se siga con la lógica de los usureros. La población civil hace suyos los planteamientos necesarios para proseguir el crecimiento con una mayor participación en la distribución del ingreso, exigiendo imperativamente el crecimiento. Por lo tanto, el país necesita, bajo un programa de largo plazo, plantear a sus acreedores la necesidad de créditos frescos para no depender de nuevas renegociaciones o depender de la baja de los precios internacionales del petróleo y lograr el crecimiento. Dicha propuesta no es ajena y sí hay posibilidades de ella en la medida que a grandes voces se clama por el crecimiento y por la cancelación de la deuda vieja y las propuestas de situaciones alternativas bajo el enfoque de un menú para cancelar viejos créditos.

El final de un ciclo sexenal y el inicio de uno nuevo propiciaron concertaciones diferentes en el ámbito del lenguaje para abordar propuestas que se relacionan con las hipótesis planteadas al inicio de este trabajo. La necesidad de la reproduc- 
ción del capital y la necesidad de recurrir a créditos frescos para proseguir con el proceso de acumulación interno interdependiente del proceso de acumulación internacional. Estos enunciados permiten entender el lenguaje de los magos de las finanzas. Así, hay una concertación en planteamientos como los siguientes:

Reducir el tamaño de la deuda externa con quitas al principal o utilizando el mercado secundario. ${ }^{1}$ Se propuso a finales de 1988 armar un paquete de reconversión de la deuda exterior de México que permitiese, sobre bases jurídicas y técnicas sólidas, una quita de capital y una quita de intereses.

Disminuir el servicio de la deuda en un 40 o $50 \%$, con el objeto de evitar transferencias reales al exterior y canalizar más el ahorro al interior de la economía nacional. ${ }^{2}$

Se abren diferentes opciones para la reducción de la deuda externa. Entre ellas:

Las conversiones de deuda por activos, las conversiones de deuda por bonos a más largo plazo y con ciertas garantías que eleven su aceptación en el mercado, "bonos de salida", pagos en moneda local destinados a la inversión, etc., tomarán un papel dentro de una estrategia global y ligado con el objetivo básico del crecimiento. En esta negociación, por supuesto, quedaría incluida una corriente de recursos financieros adicionales y posibles concesiones en materia de tasas de interés. El elemento de concesionalidad estaría ligado al desempeño del país - juzgado de una manera conjunta - y a la evolución de factores fuera del control de los deudores. ${ }^{3}$

Dar un tratamiento diferente a la "vieja deuda" con una reducción sustancial de la misma entre 20 mil y $30 \mathrm{mil} \mathrm{mi-}$ llones de dólares del principal y 2 mil o 3 mil millones de

${ }^{1}$ Martínez, Ifigenia "Suspendamos ya, el Pago de la Deuda". Excelsior, 12 de noviembre de 1988. Véase la reunión convocada por el Colegio de Economistas en el Museo de Antropología los días 9, 10 y 11 de noviembre de 1988.

${ }^{2}$ Silva Herzog, Jesús. “¿Más deuda a la deuda?”'. Excelsior. martes 22 de noviembre de 1988.

${ }^{3}$ Ibid. Véase también Banco de México. "El Enfoque de Menú al Problema de la Deuda". en Boletín de Economía Internacional, vol. XIV, núm. 3 julio-septiembre, 1988. 
dólares de intereses. En este camino es importante definir sobre qué clase de deudas recae la reducción, por ejemplo, la bancaria, y si sólo cubre el principal o sobre los intereses, u opciones de ambas, lo cual tiene efectos análogos, pero tratamientos fiscales y contables diferentes. ${ }^{4}$

El clamor por "nueva deuda" de créditos a largo plazo para el desarrollo deberá remarcarse vía el BM, el Eximbank y el BID.

El tiempo ha dado una ventaja a los acreedores que, ante el temor de una moratoria unilateral, se reservaron el derecho de suspender los nuevos créditos a los países subdesarrollados y así disponer de una mayor ventaja sobre los deudores e incrementar sus reservas. De esta forma, la ventaja para los banqueros fue dar una mayor solvencia a sus accionistas quienes veían con temor una caída en el sistema financiero internacional.

La opción para el gobierno que se inicia, lo mismo para los países hondamente endeudados, está en manos de la propuesta que desarrollen los países deudores y muy especialmente México. Esta será la de abatir el servicio y el monto de la "vieja deuda" abriendo varias alternativas para los inversionistas extranjeros y los grandes bancos japoneses y estadounidenses utilizando el enfoque de menú. No hay duda que el crecimiento será una de las alternativas fundamentales en la estrategia política del nuevo ciclo sexenal ante los embates y la debilidad que sustenta políticamente el gobierno en el poder.

En el marco de las propuestas para solucionar la deuda externa hay un énfasis en la necesidad de nuevos créditos para lograr que la economía tenga un crecimiento real. Si bien es importante resaltar la disminución de la deuda externa y del servicio de la misma, es importante contar con flujos nuevos sin esperar a futuras renegociaciones o estar dependiendo de la baja o alza de las materias primas y el petróleo. La canali-

"Suárez Dávila, Francisco. "El endeudamiento, una desmemoria histórica”. Excelsior, 22 de noviembre de 1988. 
zación de recursos para superar el decrecimiento tiene que hacerse de manera planeada, concertada y discutida por el sector público, los empresarios y los obreros, quienes sustentarían una especie de "Pacto para el crecimiento nacional". Sin la concertación de estos tres sectores y sin la ayuda del financiamiento externo difícilmente podríamos advertir un crecimiento real de la economía para la década del noventa y lo que resta del siglo $\mathrm{XX}$.

La solución a la deuda externa debe hacer énfasis en un marco multilateral. Deuda y comercio, deben tener un enfoque global. Donde los aspectos políticos nunca estarán ausentes en las renegociaciones y reprogramaciones. Es imperativo, por tanto, que México desarrolle estrategias que se inserten en un marco mundial de resolución a estos problemas. Para el efecto deben considerarse variables reales y financieras en todas sus dimensiones, incluyendo la política. Con dicho fin, debe crearse una institución internacional especial, derivada de la Asamblea de las Naciones Unidas. Donde los actores y participantes tendrían como objetivo que cada nación tome su posición basándose en un consenso nacional, democráticamente conseguido. En el organismo internacional se buscaría un consenso mundial en cuanto a metas globales de desarrollo, intercambio comercial y financiero más justo y un marco institucional más adecuado para las relaciones económicas y políticas internacionales. ${ }^{5}$

Dornbush presenta una alternativa diferente ante el difunto Plan Baker y ante la negativa de Paul Volcker de proclamar que ante el problema del endeudamiento no hay ya ninguna solución. La propuesta consiste, en primer lugar, en que

por un periodo de diez años, parte del servicio de la deuda externa, digamos el $55 \%$, sea pagada en moneda nacional. Estos pagos pueden ser usados irrestrictamente para inversión en México. La única restricción es que los acreedores no lo repatríen. A cambio, el gobierno

${ }^{5}$ Ortiz, Edgar. "Deuda Externa, Estabilización y Cambio Estructural: Inviabilidad y Solución Política Global. El Caso Mexicano’’. Ponencia al I Foro sobre Deuda Externa y Soberanía Nacional, México, agosto 18-22, 1986. 
mexicano se tomará la tarea de liberalizar y facilitar la inversión removiendo y quitando los obstáculos en la legislación. Después de diez años el principal y las ganancias acumuladas podrán ser retractadas de acuerdo a un programa y al tipo de cambio oficial imperante. En segundo lugar, una parte del servicio de la deuda será capitalizada automáticamente, digamos el $25 \%$, y en esta forma ayuda a financiar una recuperación moderada de la inversión del sector público. La tasa de interés pagada en estos préstamos es igual a la tasa de inflación de Estados Unidos más la tasa de crecimiento del ingreso per cápita de México. El retorno garantizaría que los créditos extranjeros participen en cualquier sector de la economía mexicana mientras eviten al mismo tiempo el pago global de las obligaciones del servicio de la deuda relativas a la capacidad de largo plazo. En tercer lugar, una porción igual al $20 \%$ del servicio de la deuda continúa pagándose en dólares, asegurando a los acreedores algo de ganancias. ${ }^{6}$

La propuesta que ha motivado una respuesta más definida a la problemática de pagar el servicio de la deuda externa fue la del Secretario del Tesoro de la administración del presidente Bush. El Plan Brady respondió ante los disturbios provocados por las medidas de ajuste ejercidas en Venezuela. Los acreedores deben plantearse la necesidad de reducir el saldo de la deuda externa, la disminución de los intereses, la utilización del mercado secundario. Este plan inserto en la pérdida de hegemonía estadounidense frente a Japón trata también de evitar que la deuda externa sea comprada en el mercado secundario por los japoneses y ganen espacio en la región latinoamericana. El Plan Brady fue anunciado sólo para México y Venezuela como plan piloto. Además de considerarlo por sí sólo, el gobierno estadounidense, fue apoyado por los organismos financieros internacionales y por la misma banca acreedora trasnacional. La estrategia del plan considera el problema de la deuda externa como un problema de "seguridad nacional" para Estados Unidos. El Secretario del Tesoro de Estados Unidos, presentó este plan de

${ }^{6}$ Dornbush, Rudiger. "Federal Reserve Policy in the Volcker Era: International Issue". Paper presented in the Annual Meeting Allied Social Science Association, New York City, New York, december 28-30, 1988. 
acción frente a los acreedores internacionales como una "estrategia reforzada" en el marco del cual solicitaba a los bancos comerciales que ofrecieran a los países deudores una gama más amplia de opciones financieras.

La necesidad de una acción "reforzada" es con base en el Plan Baker, el cual constó de tres elementos:

1. La adopción de políticas macroeconómicas y estructurales apropiadas por parte de los países deudores.

2. El respaldo financiero continuo del FMI y de los organismos multilaterales de desarrollo para introducir reformas de política económica.

3. Mayor volumen de crédito de los bancos privados a los países deudores.

En relación al tercer elemento, Brady propone que los bancos comerciales ofrezcan diversas modalidades de financiamiento y disminuyan las restricciones impuestas a los nuevos créditos. Pide a los bancos, concretamente, que supriman las cláusulas contenidas en los actuales acuerdos de préstamos, según las cuales se dispone que los acreedores apliquen un trato preferencial a todos sus deudores en las transacciones de negociación de las condiciones de los préstamos; lo mismo se exige de los deudores con respecto a los acreedores. Brady, sostiene que estas cláusulas representan un "obstáculo a la reducción de la deuda".?

Brady insta a las instituciones financieras internacionales a que sigan desempeñando una función primordial, fomentando políticas económicas adecuadas mediante la asesoría y el respaldo financiero.

Una vez anunciado el Plan Brady y las condiciones implícitas en él, México fue el país piloto donde se ejercería el juego entre deudores y acreedores. Así, después de firmar la Carta de Intención con el FMI, los primeros días de abril, se iniciaron las pláticas para la renegociación de la deuda externa y su disminución.

${ }^{7}$ FMI Boletín. 27 de marzo de 1989. 
Crecimiento y renegociación serán la pauta a seguir en lo que resta de los años por finalizar el siglo XX. Nuevos financiamientos "condicionados" a las necesidades del proceso de reproducción de capital, comandado por el conglomerado trasnacional y el otorgamiento de "créditos frescos" permitirán de nueva cuenta un nuevo tipo de crecimiento diferente al de las décadas de los años sesenta y setenta. Cancelación de deudas "viejas", condonación de algunas y moratorias concertadas vendrán a ocupar espacio en el lenguaje de la comunidad financiera internacional. Allí, deudores y acreedores tendrán que optar por aceptar ganancias menores, en relación a las cuantiosas ganancias obtenidas en años recientes. Los deudores imperiosamente optarán por canalizar mejor sus recursos para la ampliación de la financiación de la reproducción y la distribución de un mejoramiento en el bienestar de la gran mayoría de la población y de la sociedad. Entendemos que la lucha de clases es, desde la óptica de la economía política, el elemento clave en el avance de la historia de la humanidad. Detener dicho proceso sería un peligro para el mejoramiento de nuestros países subdesarrollados. El equivalente general es una relación social de intercambio entre una gama de necesidades para el bienestar humano.

Acercarse a un problema tan complejo como el estudio del proceso de endeudamiento de México desde los años cuarenta hasta los noventa permitió usar categorías de la economía política para entender de manera más real el proceso de la reproducción de capital en un país subdesarrollado. De esta forma, el endeudamiento externo a lo largo del estudio se presentó más que como una variable económica como un elemento de primordial importancia en la política económica y en los intereses de los acreedores. La lucha por el espacio es cada vez mayor. Dependiendo de circunstancias económicas, sociales y políticas, la deuda externa adquiere alternativas y soluciones para perseguir objetivos distintos en la lucha por el equivalente general. Deuda externa y plusvalía, 
así como deuda externa e internacionalización del capital y deudores y acreedores, son parte de un rompecabezas común. El elemento social tendrá un papel importante en el uso de la deuda externa para avanzar en su superación tal como lo planteamos en nuestra introducción, hoy bajo amenaza de una deuda enorme e impagable, se sigue postergando la satisfacción de necesidades sociales ya de por sí rezagadas por las exigencias del desarrollo impuestas desde la posguerra. Por ello el enfoque de la economía política evita quedarse en el análisis de los montos cuantitativos y así permitir propuestas de solución a la deuda externa, libres de doctrinas dominantes ejercidas en el contexto social más amplio. 


\section{ANEXO}

MÉXICO, CINCUENTA AÑOS DE DEUDA PUBLICA EXTERNA

Año Millones de pesos

Año Millones de dólares

$1940 \quad 1289680$

19642056.0

$1941 \quad 1314864$

19652114.0

$1942 \quad 1340048$

19662260.0

$1943 \quad 240632$

19672643.0

$1944 \quad 240632$

$1968 \quad 3154.0$

$1945 \quad 240632$

19693432.0

$1946 \quad 240632$

$1970 \quad 4262.8$

$1947 \quad 240632$

$1971 \quad 4545.8$

$1948 \quad 240632$

$1972 \quad 5064.8$

$1949 \quad 240632$

$1950 \quad 240632$

19737070.4

$1951 \quad 391641$

19749975.0

$1952 \quad 382243$

197514449.0

$1953 \quad 676678$

197619600.2

$1954 \quad 949990$

197722912.1

$1955 \quad 925027$

197826284.3

$1956 \quad 883974$

197929757.2

$1957 \quad 845965$

198033812.8

$1958 \quad 798005$

198152960.6

$1959 \quad 771456$

198258874.2

198365556.2

$1960 \quad 274647$

198469377.9

$1961 \quad 251526$

198572080.1

$1962 \quad 230413$

198675350.9

$1963 \quad 209718$

198781406.8

198881003.2

198976059.0

199077756.5

Fuente: SHCP. Tomado de INEGI. Estadísticas históricas de México, 1985. Nacional Financiera. El Mercado de Valores, varios números. 



\section{BIBLIOGRAFÍA}

\section{LIBROS}

Aglietta, Michel. Regulación y Crisis del Capitalismo. La experiencia de los Estados Unidos. México, Siglo XXI, 1979.

Aguilar Monteverde, Alonso. El Panamericanismo. México, Cuadernos Americanos, 1965.

-. Problemas Estructurales del Subdesarrollo. México, UNAM, 1971.

- La crisis del Capitalismo. México, Editorial Nuestro Tiempo, 1979.

Amin, Samir. La acumulación a escala mundial. Política de la teoría del subdesarrollo. México, Siglo XXI, 1977.

Alvarez Uriarte, Miguel. Financiamiento al Comercio Exterior de México. México, El Colegio de México, 1985.

Arroyo, Gonzalo. "El Desarrollo de la Biotecnología: Desafíos para la Agricultura y la Agroindustria", en Revolución Tecnológica y Empleo. Biogenética y Agricultura. México, STP, PNVD, OIT, 1986.

Bailey, Norman A. y Richard Cohen. La Bomba de Tiempo Mexicana. Un ensayo de la Twentieth Century Fund. México, Grijalbo, 1987.

Baran, Paul y M. Sweezy. El Capital Monopolista de Estado, (ensayo sobre el orden económico y social de los Estados Unidos). México, Siglo XXI, 1973.

Bobbio, Norberto y Nicola Matteucci. Diccionario de Política. México, Siglo XXI, 1981.

Brunhoff, Suzanne de. La Concepción monetaria de Marx, Ediciones del Siglo, Buenos Aires, 1973.

- La política monetaria. Un ensayo de integración marxista. México, Siglo XXI, 1974.

-. Teoría Marxista de la Moneda. México, Ediciones Roca. 1975.

Bujarin, Nicolai I. La economía mundial y el imperialismo. México, Siglo XXI, 1974.

- La economía mundial y el imperialismo. México, Siglo XXI, 1976.

Cardero, María Elena y José Manuel Quijano. "Expansión y estrangulamiento financiero 1978-1981" en la Banca: Pasado y Presente. México, Ensayos del CIDE, 1983.

Cardero, María Elena. Patrón Monetario y Acumulación en México. (Nacionalización y Control de Cambios). México, Siglo XXI, 1984. 
Cardoso, F.H. y Enzo Faletto. Dependencia y desarrollo en América Latina, Ensayo de interpretación sociológica. México, Siglo XXI, 1977.

Carmona, Fernando y otros. El Milagro Mexicano. México, Editorial Nuestro Tiempo, 1970.

Carmona, Fernando. "La crisis general del capitalismo y la crisis económica mexicana actual", en México, el curso de una larga crisis UNAMEditorial Nuestro Tiempo, 1987.

Castells, Manuel. La teoría marxista de las crisis económicas y las transformaciones del capitalismo. México, Siglo XXI, 1978.

Castañeda, Jorge y Enrique Heet. El economismo dependentista. México, Siglo XXI, 1978.

Ceceña, José Luis. El Imperio del Dólar. México, Ediciones El Caballito, 1972.

Colmenares, Francisco. Petróleo y lucha de clases en México 1864-1982. México, Ediciones El Caballito, 1982.

- Problemas de Rentabilidad y Productividad de la Industria Petrolera Mexicana 1970-1984. Tesis de Maestría en Estudios Latinoamericanos, México, Facultad de Ciencias Políticas y Sociales, UNAM.

Conde, Raúl et al. La crisis actual y los modos de regulación del capitalismo. Cuadernos Universitarios, núm. 8, México, Universidad Autónoma Metropolitana-Iztapalapa, 1984.

Cordera, Rolando y Carlos Tello. México; la disputa por la nación. México, Siglo XXI, 1981.

Cornia, Jolly y Stewart. Ajuste con Rostro Humano (Protección de los grupos vulnerables y promoción del crecimiento). Madrid, UNICEF y Siglo XXI de España, 1987.

Cuevas, Agustín. El Desarrollo del capitalismo en América Latina. México, Siglo XXI, 1977.

Chapoy Bonifaz, Alma. Empresas Multinacionales (Instrumento del Imperialismo). México, Ediciones El Caballito, 1972.

-. Ruptura del Sistema Monetario Internacional. México, UNAM, 1979.

De la Peña, Sergio. "La deuda externa : nuevo fiel de la balanza" en La sucesión presidencial en 1988. México, Grijalbo, 1987.

Dillard, Dudley. La teoría económica de John Maynard Keynes, Teoría de una economía monetaria. Madrid, Aguilar, 1971.

Dos Santos, Theotonio. Imperialismo y dependencia. México, Era, 1978.

- La dependencia político-económica de América Latina, México, Siglo XXI, 1968.

- La crisis capitalista: Carácter y perspectivas. México, Cuadernos del CEPAL, 1977.

Estévez, Jaime y Samuel Lichtensztejn. Nueva Fase del Capital Financiero. (Elementos teóricos y experiencias en América Latina). México, CEESTEM-ILET-Editorial Nueva Imagen, 1981. 
Furtado, Celso. Creatividad y dependencia. México, Siglo XXI, 1979.

-. El desarrollo económico: un mito. México, Siglo XXI.

Friedman, Milton y Rose Friedman. Libertad para elegir. España, Grijalbo, 1981.

Friedman, Milton. Teoría de los precios, apuntes para un curso en la Universidad de Chicago. Madrid, Alianza Editorial, 1966.

Galeano, Eduardo. Las venas abiertas de América Latina. México, Siglo XXI.

González Casanova, Pablo y Héctor Aguilar Camín. "México ante la crisis mundial"' en México ante la crisis. México, Instituto de Investigaciones Sociales, UNAM. Siglo XXI, vol. 1, 1985.

Gorostiaga, Xavier. Los centros financieros internacionales en los países subdesarrollados. México, ILET, 1978.

Green, Rosario. Estado y Banca Trasnacional en México. México, CEesTerM y Editorial Nueva Imagen 1981.

-. El endeudamiento público externo de México 1940-1973. México, El Colegio de México, 1976.

-. La Deuda Externa de México: 1973-1987. De la abundancia a la escasez de créditos. México, Secretaría de Relaciones Exteriores y Editorial Nueva Imagen, 1988.

- Los mitos de Milton Friedman. México, CEESTERM, Editorial Nueva Imagen, 1983.

Gunder Frank, André. América Latina: subdesarrollo o revolución, México, Era, 1973.

-. Capitalismo y Subdesarrollo, México, Era, 1970.

Guillén Romo, Héctor. Origenes de la crisis en México. (Inflación y endeudamiento externo 1940-1982). México, Era, 1984.

Hilferding, R. El capital financiero. México, Ediciones El Caballito, 1973.

Hansen, Roger D. La política del desarrollo mexicano. México, Siglo XXI 1974.

Harsen, Alvin H. Guía de Keynes. México, Fondo de Cultura Económica, 1957.

Jourdain, G. y J. Valier. "El fracaso de las explicaciones burguesas de la inflación", en Ernest Mandel. La inflación. Buenos Aires, Argentina, Rodolfo Alonso Editor, 1970.

Keynes, John Maynard. Teoría general de la ocupación, el interés y el dinero. México, Fondo de Cultura Económica, 1943.

Lenin, V.I. El imperialismo, fase superior del capitalismo. Moscú, Ediciones en Lenguas Extranjeras, tomo I.

Levinson, Charles. Capital, inflation and the multinationals. Nueva York, Macmillian Company, 1971.

Maddison, Angus. Las Fases del Desarrollo Capitalista. México, El Colegio de México, Fondo de Cultura Económica, 1980.

Magdoff, Harry. La era del imperialismo. Monthly Review, 1976. 
Manrique, Irma. La política monetaria en la estrategia del desarrollo. Su impacto en América Latina y México. México, Editores Asociados, 1979.

Malagón Vera, Alfonso. La administración de la deuda pública externa. Contribución al estudio de la crisis de la deuda. Premio Nacional de Administración Pública 1985. México, INAP, 1987.

Marini, Ruy Mauro. Subdesarrollo y Revolución. México, Siglo XXI, 1969.

Marsh, Donal B. Comercio Mundial e Inversión Internacional. México, Fondo de Cultura Económica, 1957.

Marx, Carlos. Contribución a la crítica de la economía política. México, Ediciones de Cultura Popular, 1974.

-. El Capital. México, Siglo XXI, 1977.

Montgomery, John D. Foreing aid in international politics. New Jersey, Prentice Hall, Inc.

Ortíz Mena, Antonio. América Latina en desarrollo. Una visión desde el BID. (Exposiciones y documentos 1981-1985). Washington, 1986.

Osorio Paz, Saúl. Impacto de la deuda externa en las pequeñas economías de la cuenca del Caribe. México, IIEc-UNAM y Editorial Praxis, 1987.

Palloix, Christian. Las firmas multinacionales y el proceso de internacionalización. Madrid, Siglo XXI de España, 1975.

- La internacionalización del capital. Madrid, Blume Ediciones, 1975.

Paniagua Ruiz, Rafael. Prolegómenos para una teoría de los límites financieros del Estado: problemas de la deuda y crisis financiera. México, Universidad Autónoma Metropolitana-Iztapalapa, Cuadernos Universitarios núm. 30, 1985.

Pastor, Manuel. The International Monetary Fund Latin America. West View, 1988.

Prebisch, Raúl. Hacia una dinámica del desarrollo latinoamericano. México, Fondo de Cultura Económica, 1971.

Proceso. Pemex: La caida de Díaz Serrano. México, Proceso, 1981.

Quijano, José Manuel. México: Estado y banca privada. México, CIDE, 1981. Rolfe, S. y W. Damm. The multinational corporation in the World Economy.

Nueva York, Praegers Publishers Inc., 1970.

Sacristán Colas, Antonio. Keynes ante la crisis mundial de los años ochenta. México, Siglo XXI, 1985.

Saldivar, Américo. Ideología y política del Estado Mexicano, 1970-1976. México, Siglo XXI, 1980.

Saxe Fernández, John. Petróleo y estrategia: México y Estados Unidos en el contexto de la política global. México, Siglo XXI, 1980.

Sistema Económico Latinoamericano. El FMI, el Banco Mundial y la crisis latinoamericana. México, Siglo XXI, 1986.

Secretaría de Hacienda y Crédito Público. Deuda Externa Pública. México, Fondo de Cultura Económica y SHCP, 1988.

Street, James H. "Mexican economic policy and U.S. bail outs: the new dependency', en William Cole. Mexico's economic policy: past, present and 
future. Knoxville, University of Tennesse, Center for Business and Economic Research, 1987.

Tanzer, Michael. The political economy of international Oil and the underdeveloped countries. Boston, Beacon Paperback 370, 1969.

Tello, Carlos. La Nacionalización de la Banca en México. México, Siglo XXI, 1984.

- La política económica en México. 1970-1976. México, Siglo XXI, 1979.

Trias, Vivian. La crisis del dólar y la política norteamericana. Barcelona, Ediciones Península.

Torres Gaitán, Ricardo. Un siglo de devaluaciones del peso mexicano, México, Siglo XXI, 1980.

Varios Autores. El capitalismo monopolista de Estado. México, Ediciones de Cultura Popular.

Villarreal, René. La contrarrevolución monetarista. Teorí, política económica e ideología del neoliberalismo. México, Ediciones Océano.

Williams, A. James. El petróleo en México: efectos macroeconómicos, elementos de política y perspectivas. México; El Colegio de México, Programa de Energéticos, 1984.

\section{ARTÍCULOS}

Acevedo, Carrillo, Agustín, "La Crisis de la Deuda Petrolera". Proyecto Lázaro Cárdenas Facultad de Ciencias Políticas y Sociales, UNAM. (mimeo).

Aguilar, Alonso. "El capitalismo del subdesarrollo: Un capitalismo sin capital y sin perspectivas" en Problemas del Desarrollo, núm. 8, Instituto de Investigaciones Económicas, UNAM, México, 1971.

Altman, Oscar L. "Eurodólares", en Finanzas y Desarrollo, vol. IV, núm. 1, marzo de 1967.

Arroyo, Gonzalo. "La revolución biotecnológica y la nueva inserción de la agricultura y de la agroindustria en la división internacional del trabajo", Congreso de economistas de América Latina. La Habana, noviembre de 1987.

—. "Modelo de acumulación, clases sociales y agricultura", en Estudios Sociales Centroamericanos; enero-abril de 1979, año VIII, núm. 22.

- . "Firmas trasnacionales, agroindustrias, reforma agraria y desarrollo rural", en Investigación económica, núm. 147, enero-marzo de 1979. Banco de México. "El enfoque de menú al problema de la deuda", en Boletín de Economía Internacional, vol. XIV, núm. 3, julio-septiembre. de 1988.

-. "El mercado secundario de la deuda de los países en desarrollo", en Boletín de Economía Internacional, vol. XIV, núm. 3, julio-septiembre. de 1988. 
Banco Nacional de Comercio Exterior. "México: la política económica del nuevo gobierno", en Comercio Exterior, México, vol. XX, núm. 12, diciembre de 1970.

Banfi, Rodolfo. “A propósito de El Imperialismo de Lenin”, en Varios. Teoría marxista del imperialismo, México, Siglo XXI, 1973.

Bates y Donaldson. "La mayor importancia del crédito al sector rural", en Finanzas y Desarrollo, vol. 12, núm. 2, junio de 1975.

Bernal Sahagún, Víctor Manuel. "La inversión extranjera directa, las empresas multinacionales y los ingresos en México", en Investigación Económica, México, UNAM.

- . "La publicidad: economía y política de los medios masivos", en Problemas del Desarrollo, México, núm. 31.

Boron, Atilio. "El problema del aparato de Estado en el capitalismo contemporáneo: notas preliminares para una investigación". (manuscrito), XII Congreso latinoamericano de sociología, Quito Ecuador, noviembre de 1977.

Carmona Fernando. "La crisis capitalista está en el petróleo", en Estrategia, México, núm. 41, septiembre-octubre de 1981.

Clyde Mark. "México en el ámbito de E. U. para la ocupación militar de pozos petroleros" en El Día, México, 9 de abril de 1981.

Colmenares, Francisco. "El excedente petrolero en el auge de la crisis en México (1970-1984)'", en Edgar Ortiz (comp.) Empresas públicas, problemas actuales de Norteamérica y el Caribe. México: CIDE-NAEFA, 1988.

Colmenares Páramo, David. "El FMI en la economía mundial y su intervención en México"', en El Día, 5 de diciembre de 1978.

Cordera, Rolando. "Estado y desarrollo en el capitalismo tardío y subordinado", en Investigación Económica, vol. XXXI, núm. 123, julioseptiembre de 1971.

Cueva, Agustín. "Problemas y perspectivas de la teoría de la dependencia", en Historia y Sociedad, núm. 3, otoño de 1974.

Chapoy Bonifaz, Alma. "Las inversiones extranjeras. Decretos en el sexenio de Echeverría". En Investigación Económica, núm. 4, México, octubre-diciembre; 1971.

De Bernis, Gérard. "La articulación de las leyes de ganancia", ponencia presentada en el ciclo "Fase y crisis actual del capitalismo internacional". Seminario de Teoría del Desarrollo, IIEc, UNAM y Departamento de Economía UAM-I, México, 1984.

De la Vega Navarro, Angel. "La energía en el contexto de algunas tendencias recientes de la economía capitalista internacional", conferencia en el IX Seminario Problemas de la economía mundial contemporánea del doctorado de economía de la DEP de la UNAM, México, enero de 1982. De Munguía, Valdemar. "Fuga de capitales y crisis económica: los capitales exiliados mexicanos después de la devaluación en una comu- 
nidad de California", en Investigación Económica, núm. 181, México, julioseptiembre de 1987.

Ferrer, Aldo. "Acumulación, cambio tecnológico y deuda externa", en Comercio Exterior, vol. 37, núm. 12, México, diciembre de 1987.

García, Antonio. "Una teoría latinoamericana del desarrollo", en Problemas del Desarrollo, núm. 17, México,

Green, Rosario. "La deuda pública externa de México 1965-1976", en Comercio Exterior, vol. 27, núm. 11, México, noviembre de 1977.

- . "Deuda externa y política exterior: la vuelta a la bilateralidad en las relaciones internacionales de México", en Foro Internacional, México, julio-septiembre de 1978.

- . "Deuda pública externa y dependencia. El caso de México", en $\mathrm{Fo}_{0}$ ro Internacional, vol. XIII, núm. 50, México, octubre-diciembre de 1972. Gilly, Adolfo. "La modernización del capitalismo mexicano", en Nexos, núm. 97, México, enero de 1986.

Martínez, Ifigenia. "Suspendamos ya, el pago de la deuda", en Excelsior, México, 12 de noviembre de 1988.

Kapur, Ishan. "Fondos en eurodivisas para los países en desarrollo", en Finanzas y Desarrollo, vol. 14, núm. 3, septiembre de 1977.

Klein M., Thomas. "La situación de la deuda externa de los países en desarrollo", en Finanzas y Desarrollo, vol. 13, núm. 4, diciembre de 1976.

Lichtensztejn, Samuel. "Notas sobre el capital financiero en América Latina", en Revista de Economía de América Latina, núm. 4, México, marzo de 1980.

- . "Sobre el enfoque y el papel de las políticas de estabilización en América Latina", en Revista de Economía de América Latina, núm. 1, México, septiembre de 1978.

Martínez Escamilla, Ramón. "A 50 años de la expropiación. El petróleo mexicano en la estructura energética mundial", Excelsior, México, 28 de febrero de 1988.

Márquez, Miguel H. "La industria del gas natural en México", en Problemas del Desarrollo, núm. 75, México,

Molina Warner, Isabel. "El endeudamiento externo del sector privado y sus efectos en la economía mexicana", en Comercio Exterior, vol. 31, núm. 10, México, octubre de 1981.

Montgue, Yudelman. "El crédito agrícola del Banco 1974-1984", en Finanzas y Desarrollo, vol. 21, núm. 4, diciembre de 1984.

NACLA. "Mexican Economy", en NACLA Report, febrero de 1983.

Nava, José Manuel. "La Agencia Internacional de Desarrollo", en Excelsior, México, 15 de noviembre de 1978.

Navarrete, Jorge Eduardo. "La deuda externa y el Plan Baker", en Investigación Económica, núm. 175, México, enero-marzo de 1986. 
O'Donnell, Guillermo. "Reflexiones sobre las tendencias del cambio del Estado burocrático autoritario". Revista Mexicana de Sociología, año XXXIX, vol. XXXIX, núm. 1, México, enero-marzo de 1977.

Ortiz, Edgar. "Crisis y deuda externa: limitaciones de las políticas de estabilización y alternativas para el desarrollo y la renegociación del endeudamiento", ponencia en el Congreso Nacional de Economistas, Oaxaca, 1987.

—. "Deuda externa, estabilización y cambio estructural: inviabilidad y solución política global. El caso mexicano"', ponencia en el I Foro sobre Deuda Externa y Soberanía Nacional, México, 18-22 de agosto de 1986.

Phillips Olmedo, Alfredo. "La deuda pública externa de México y la política crediticia de los organismos internacionales", en El Mercado de Valores, año XLI, núm. 23, México, 8 de junio de 1981.

Rama, Ruth, Rello, Fernando y Arroyo, Gonzálo. Revista Investigación Económica enero-marzo, 1979. Vo. XXXVIII, Facultad de Economía, UNAM.

Retchkiman, Benjamín. "La 'reforma' fiscal en México", en Problemas del Desarrollo, núm. 19, México,.

-. "Política fiscal mexicana", en Problemas del Desarrollo, núm. 24, México, 1985.

Rubichek, Walter E. "Consideraciones sobre el endeudamiento público externo", en Finanzas y Desarrollo, vol. 17; núm. A, marzo de 1980. Ruiz Durán, Clemente. "Financiamiento del desarrollo e innovación financiera", en Investigación Económica, vol. XLVI, núm, 182, México, octubre diciembre de 1987.

Salinas de Gortari, Carlos. "Modernización y cambio estructural, divisa de nuestro tiempo", en Comercio Exterior, vol. 37, núm. 2, México, febrero de 1987.

Silva Herzog, Jesús. “‘ ¿Más deuda a la deuda?, en Excelsior, México, 22 de noviembre de 1988 .

Suárez Dávila, Francisco. "El endeudamiento, una desmemoria histórica", en Excelsior, México, 22 de noviembre de 1988.

- . "El financiamiento externo como reto del desarrollo", en El Mercado de Valores, núm. 8, México, 15 de abril de 1988.

“'Burro's debt", en The Economist, 21 de agosto de 1982.

"'The crash of 1982 Banks feel the earth move under their feet", en The Economist, octubre de 1982. 


\section{DOCUMENTOS E INFORMES}

BID. Deuda externa: crisis y ajuste. Progreso económico y social en América Latina. Informe, Washington, 1985.

-. Latin American external indebteness: current situation and prospects, Washington.

- " "Observaciones en la Sesión de clausura de la XIII Reunión anual de la Asamblea de Gobernadores del Banco Interamericano de Desarrollo", Quito, 12 de mayo de 1972.

- Reunión Extraordinaria de la Asamblea de Gobernadores, Washington, D.C., diciembre de 1978. Informe Anual, 1986 (varios números) Washington, D.C. E.U.A.

Banco de México. Informe anual, México, 1983.

Banco Mundial. Borrowing in international capital markets, EC-181/782, Washington.

- External public debt of developing countries. World debt tables, EC-167/78, Washington.

-. Informe del Banco Mundial, Washington.

Banco Nacional de Comercio Exterior. "México: la política económica del nuevo gobierno", en Comercio Exterior, México, 1971.

Centro de Estudios Monetarios Latinoamericanos. Boletín del Centro del CEMLA, suplemento, vol. XXV, núm. 3, mayo-junio de 1979.

CEPAL. "El desarrollo económico y social y las relaciones externas de América Latina". Doc. E/CEPAL/A.C. 70/2. marzo de 1977.

- . "Notas para el estudio económico de América Latina y el Caribe", México, julio de 1986, 1987 y 1988.

Comisión Nacional de Inversiones Extranjeras y Secretaría de Hacienda y Crédito Público. Manual Operativo para la Capitalización de Pasivos y Sustitución de Deuda Pública por Inversión, México, 1986.

FMI. Document of International Monetary Fund and not for public use, FBS-76-424, 23 de septiembre de 1976.

- World Economic Outlook, Washington, octubre de 1987.

Nacional Financiera. La Economía Mexicana en Cifras, México,

—. "Plan Nacional de Desarrollo 1983-1988", en El Mercado de Valores, suplemento, año XLIII, núm. 24, 1983.

Secretaría de Hacienda y Crédito Público y Secretaría de la Presidencia.

"La Hacienda Pública" en México a través de los Informes Presidenciales, vol. IV, tomo 2, México, 1976.

Secretaría de la Presidencia de la República. Informes Presidenciales.

- . "Pacto de Solidaridad Económica", firma del Pacto de Solidaridad Económica, Salón Carranza, Los Pinos, 15 de diciembre de 1987.

Departamento de Comercio de Estados Unidos. Survey or Current Business, varios números. 
El endeudamiento externo visto como una categoria del equivalente general, bajo la óptica de la economía politica, formula una hipotésis cuyo eje es la función del dinero con bdas sus especificaciones en las relaciones de producción y como articulador de un sistema mundial de reproducción. El estudio analiza el financiamiento a tavés de los organismos financieros internacionales y de la banca privada transnacional. Destacando la canalización de dichos créditos a los diferentes sectores de la economia, se demuestra la intima relación entre

el crédito y el proceso de acumulación nacional $\theta$ internacional. El endeudamiento dejará de ser una variable económica para asi elevar la deuda social y volverse un problema polítioo. A raíz de la crisis financiera en la década de los ochenta se busca una alternativa de solución que concluirá en múltoples renegociaciones y varios planes de estabilización del Fondo Monetario Internacional, provocando un cambio estructural que definirá un proceso de liberalización y privatización, base de un nuevo modelo de desarrollo totalmente diferente al establecido durante los últimos cincuenta años. El presente libro ubica el proceso de endeudamiento externo en México desde 1940 hasta la última renegociación de febrero de 1990 en el marco del Plan Brady.

\section{La doctora Alicia Girón fue Premio Universidad}

Nacional para Jóvenes Académicos en el campo de la Investigación en Ciencias Económico-Administrativas 1990. Es egresada de la Facultad de Economía. Cursó la maestría y el doctorado en Estudios Latinoamericanos en la Facultad de Ciencias Politicas y Sociales habiendo obtenido la medalla Gabino Barreda en ambos. En el examen de grado obtuvo Mención Honorífica. En 1990 obtuvo el Diplomado en Banca y Finanzas en la Universidad Anáhuac. Pertenece al SNI. Es presidenta de la Asociación de Licenciadas en Economia 1991-1993. 